Portland State University

PDXScholar

\title{
The Holocene Sedimentary Framework of the Lower Columbia River Gorge
}

\author{
Edward Breed Gates \\ Portland State University
}

Follow this and additional works at: https://pdxscholar.library.pdx.edu/open_access_etds

\section{Let us know how access to this document benefits you.}

\section{Recommended Citation}

Gates, Edward Breed, "The Holocene Sedimentary Framework of the Lower Columbia River Gorge" (1994). Dissertations and Theses. Paper 4801.

https://doi.org/10.15760/etd.6684

This Thesis is brought to you for free and open access. It has been accepted for inclusion in Dissertations and Theses by an authorized administrator of PDXScholar. Please contact us if we can make this document more accessible: pdxscholar@pdx.edu. 
An abstract and thesis of Edward Breed Gates for the Masters of Science degree in Geology were presented April 8, 1994 and accepted by the thesis committee and the department.

COMMITTEE APPROVALS

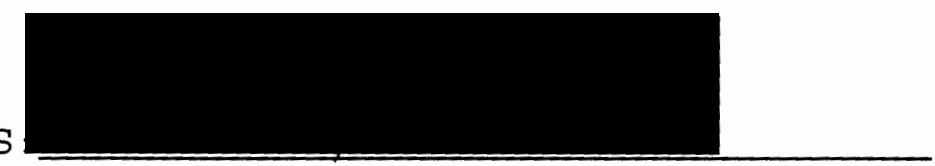

Curt D. Peterson, Chair

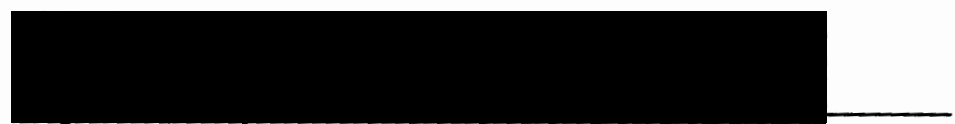

Marvin 14 . Beeson

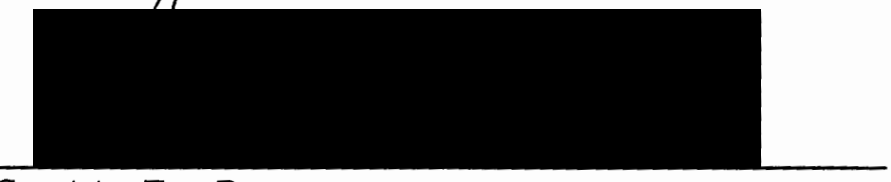

Scott F. Burns

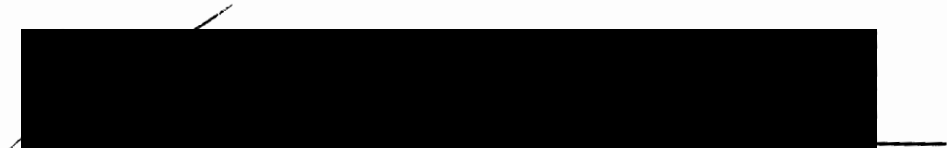

Kenneth M. Ames

Representative of the Office of Graduate Studies

DEPARTMENT APPROVAL:

Majrvin H. Beeson, Chair

Department of Geology

ACCEPTED FOR PORTLAND STATE UNIVERSITY BY THE IIBRARY

on

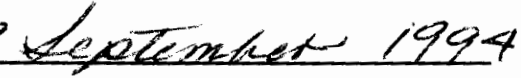


ABSTRACT

An abstract of the thesis of Edward Breed Gates for the Masters of Science in Geology presented April 8, 1994.

Title: The Holocene Sedimentary Framework of the lower Columbia River Basin.

The Columbia River is the largest fluvially dominated estuary in the Pacific Northwest, yet the Holocene transgressive fill of this system has not previously been studied. Nearly 1500 industry borehole and water well records in the lower Columbia River basin (LCRB) were analyzed. These records document the sedimentary infilling of the lower 120 miles of the drowned river valley that occurred during the Holocene marine transgression (10-0 ka). Of particular importance is a key stratigraphic marker horizon of volcanic tephra that has been identified throughout the LCRB. INAA was used to determine the geochemical composition of the target tephra layer. The tephra geochemistry was then compared to geochemical data from potential Cascade source volcanos to determine whether the tephra layers are geochemically related, and the possible age and source of the tephra. The geochemical comparisons indicate that the suspect tephra horizon was 
derived from the climax eruption of Mount Mazama approximately 6845 years ago.

Cross-sections have been constructed that record the lateral and longitudinal depositional development of the river basin. Sediment grain size distribution data have also been compiled and shows that grain size distribution does not change with respect to subsurface elevation within the LCRB. The results indicate that the LCRB has been dominated by fine sand deposition throughout the Holocene period, and silt and clay sized fractions were bypassed through the system to be deposited offshore.

A total volume of $74.6 \mathrm{~km}^{3}$ of sediment has accumulated in the basin since the time of the catastrophic floods 12,700 years ago. Sediment volume analysis was used to predict past fluvial sediment supply rates and sediment retention. The volume of sediment deposition from early to late Holocene time has decreased by a factor of 2.4 .

Sedimentation rates in the basin are estimated from a basin isopach of the Holocene fill and from an extrapolated sediment sea-level curve. Basin sedimentation rates ranged from $12.6 \mathrm{~mm} / \mathrm{yr}^{-1}$ for the early Holocene to $2.5 \mathrm{~mm} / \mathrm{yr}^{-1}$ for the late Holocene period. This factor of 5 decrease in the sedimentation rate also indicates that the Columbia River bypassed much of its fine grained fraction through to the marine environment during the mid-late Holocene. 
THE HOLOCENE SEDIMENTARY FRAMEWORK OF THE LOWER COLUMBIA RIVER BASIN

by

EDWARD BREED GATES

A thesis submitted in partial fulfillment of the requirements for the degree of

\author{
MASTERS OF SCIENCE \\ in \\ GEOLOGY
}

Portland State University

1994 


\section{ACKNOWLEDGEMENTS}

This thesis is dedicated to Ken Robbins. The idea of studying the Holocene deposits of the lower Columbia River basin was made possible because Ken had carefully maintained records for about 145 occurrences of tephra in the Portland, Oregon and Longview, Washington areas of the LCRB. Ken's detailed data of the Mazama ash layer were kindly donated for the purpose of continuing his research of the LCRB Holocene deposits. I express my utmost gratitude to Ken Robbins for his generous and insightful contributions.

I also greatly appreciate the contributions of industry borehole logs, water well logs, and supplemental information from the following organizations: Dames and Moore inc., Portland, Oregon, Fujitani and Hilts, inc., Portland, oregon, L.R. Squires inc., Lake Oswego, Oregon, Oregon Department of Transportation Region I and II offices, Department of Oregon Geology and Mineral Industries, Northwest Oil and Gas Report, U.S. Geological Survey Water Resources, Oregon Division, Washington Department of Transportation Region IV office, U.S. Army Corps of Engineers, Portland Division, and the Washington Department of Ecology.

I express my thankful appreciation to the many individuals from the organizations listed above, who aided with my research efforts and data gathering: Doug Schwarm, 
Nancy Fargo, Alan Bean, Phil Grubaugh, Steve Davis, Rich Watanabe, Bernie Klutsh, Sue D'Agnese, Anne Durley, Ian Madin, Glenn Snyder, and Rod Caldwell.

Additional data contributions from Jerry Glenn, U.S. Geological Survey, Denver, Colorado, were very much appreciated.

Funding for radio-carbon dates was provided by a grant from the U.S. Geological Survey Water Resources Division. Finally, I would like to thank all of the faculty at Portland State University department of Geology for their support and instruction. Committee members Dr. Scott Burns, Dr. Marvin Beeson, and Dr. Ken Ames all provided critical reviews and helpful comments. Lastly, I would like to express my highest gratitude to my primary advisor Dr. Curt Peterson, who provided extensive discussions, reviews, critical commentary, insightful ideas, and most of all, patience in helping me complete this thesis. 
TABLE OF CONTENTS

PAGE

ACKNOWLEDGEMENTS $\ldots \ldots \ldots \ldots \ldots \ldots \ldots \ldots \ldots \ldots \ldots \ldots$

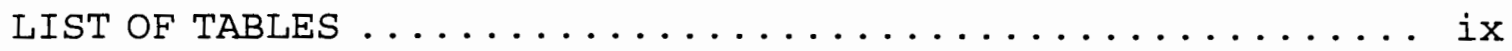

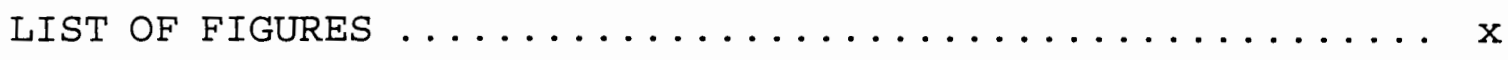

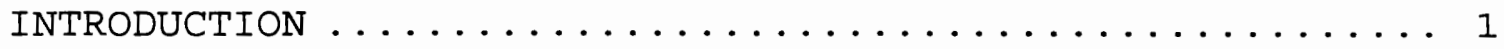

BACKGROUND AND PREVIOUS WORK $\ldots \ldots \ldots \ldots \ldots \ldots \ldots \ldots \ldots \ldots \ldots \ldots \ldots$

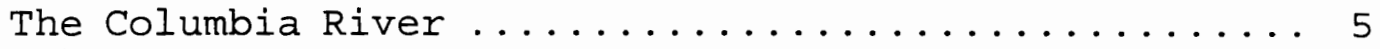

Holocene Tephras ........................ 7

Sedimentary Geology of the lower Columbia River ..... 12

Structural Development of the Study Region ......... 20

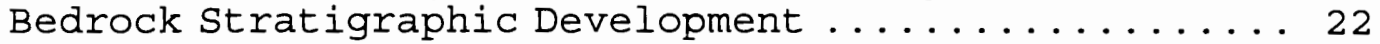

Sea Level Changes ....................... 28

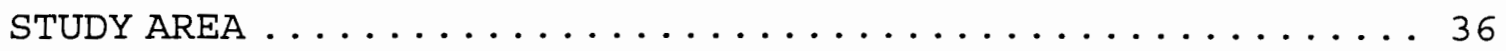

METHODS OF INVESTIGATION .................. 38

Tephra Core Data in the Columbia River Valley Fill . . 38

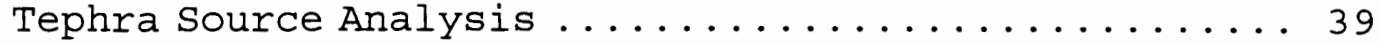

Compilation of Borehole logs ................. 41

Analysis of Borehole Data Used for Cross-sections ... 46

Analysis of the sediment Partition Data .......... 48

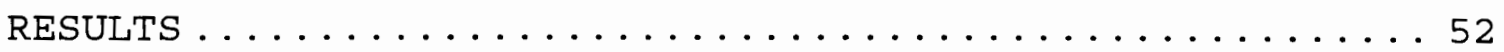

The Mazama Ash Layer ..................... 52

Geochemical Analysis of the Target Ash Layer ....... 55

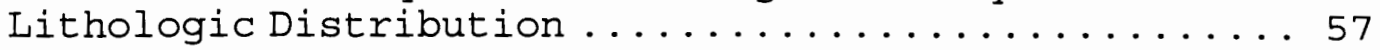

Lithologic Grain size Data ................... 80

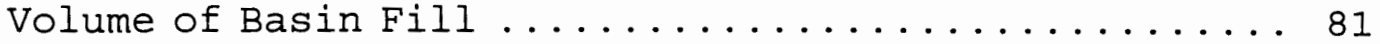

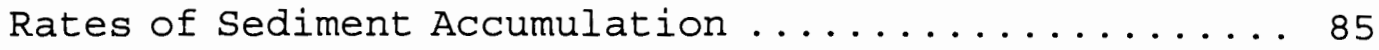

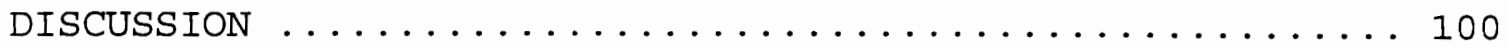

Mazama Ash Geochemistry ..................... 100

Ancestral River Valley Morphology and Basin Fill ... 103

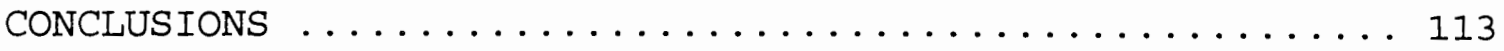


TABIE OF CONTENTS (continued)

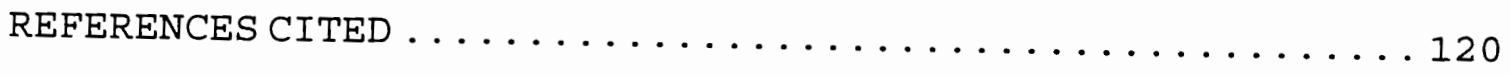

APPENDICES

A. GEOCHEMICAL DATA AND ELEMENT CONCENTRATION

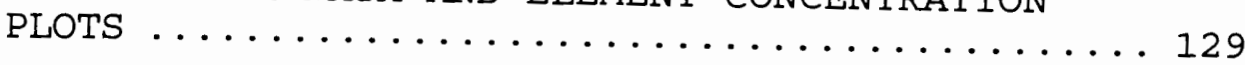

B. DATABASE OF BOREHOLE RECORDS .................. 153

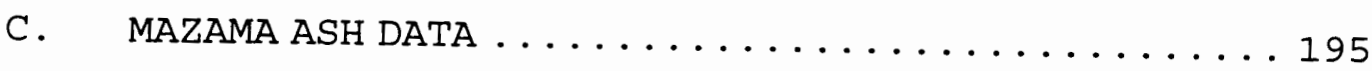

D. SEDIMENT GRAIN SIZE DISTRIBUTION DATA ........ 203 


\section{LIST OF TABLES}

TABLE

PAGE

I Volcanic Ash Layers of Moderate to Large Volume Erupted during Latest Pleistocene and Holocene Time ........................ 8

II Hindcast Sediment Discharge Rates at Vancouver, Washington, by Historic Period ........... 13

II Sediment Discharge Estimates from the Columbia

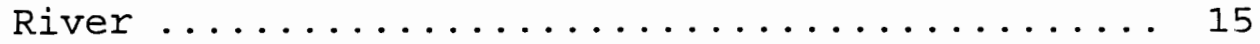

IV Appendix B Example Table ................ 43

V Holocene sediment Volume Calculations ........ 83

VI Modern Discharge Rates Hindcast to Past Depositional Rates .................. 86

VII Sediment Contribution of the Cowlitz River to the Columbia River after the 1980 Eruption of Mount st. Helens ................... 93

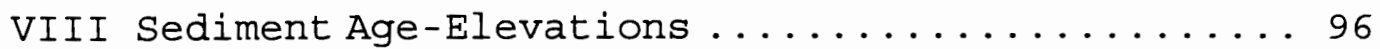




\section{LIST OF FIGURES}

1. Map of lower Columbia River Drainage basin (Simenstad and others, 1990) ............. 6

2. Areal Distribution of latest Quaternary Tephra Units. Distributions shown for Tephra Units are Probably Minimal. Distribution shown for Mazama Ash (Layer O) is a Composite of Several Lobes

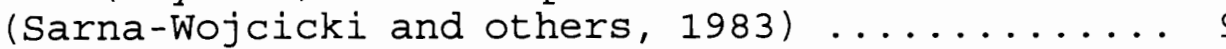

3. Minimum extent of Mazama ash (patterned) in the western United States and Canada. Circles mark sites where ash layer has been identified

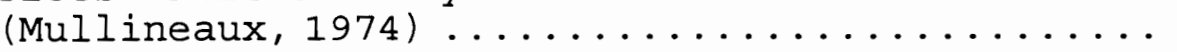

4. Sedimentary environments of the lower Columbia River estuary (Sherwood and Creager, 1990) .... 19

5. Tectonic setting of the oregon and Washington Coast showing the Cascadia Subduction Zone trench, Jaun de Fuca Plate, and smaller segments at each end. The cascade volcanic arc paraliels the trench at about $250-300 \mathrm{~km}$ inland ....... 2 I

6. Holocene sea level history for southern San Francisco Bay (Atwater and others, 1977) ..... 29

7. Generalized curve of world wide sea level rise (Kraft, 1971,) and curve of sediment deposition from Tillamook Bay, Oregon (Glenn, 1978) ..... 31

8. Sediment level curve for Grays Harbor Washington (Peterson and Phipps, 1992). Note the abrupt decrease in sediment accumulation about 7,000

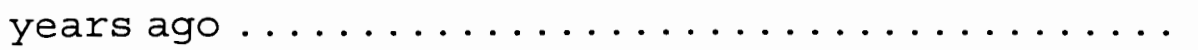

9. Sea level plot of carbon dates from Clatsop plains (Rankin, 1983) compared to sea level curves from various sources, (modified from Curry, Shepard, and Veech, 1970 and Bloom,

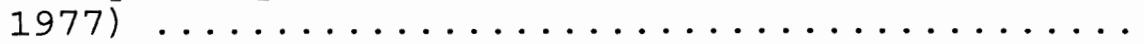


LIST OF FIGURES (continued)

FIGURE

PAGE

10. Locations mentioned in text. $\mathrm{RM}=$ River mile, coordinates are in UTM, zone 10. Study area extends from Cape Disappointment to the Sandy

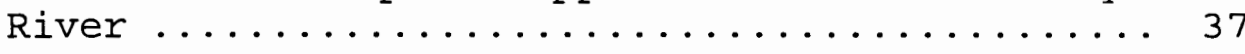

11. Location of Astoria bridge cross-section ...... 60

12. Astoria bridge cross-section ............. 61

13. Location of Puget Island bridge cross-section .. 62

14. Puget Island bridge cross-section .......... 63

15. Location of Oak Point, Washington to Locoda, Oregon cross-section .................665

16. Oak Point, Washington to Locoda, Oregon

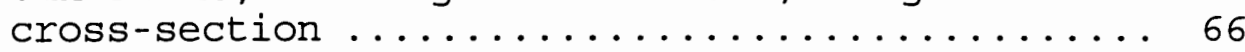

17. Location of Longview bridge cross-section ..... 69

18. Longview bridge cross-section ............. 70

19. Burlington, Oregon to Vancouver, Washington cross-section location. Contour lines represent 10 meter isopach on Holocene and late Pleistocene fine-grained deposits .......... 72

20. Burlington, Oregon to Vancouver, Washington

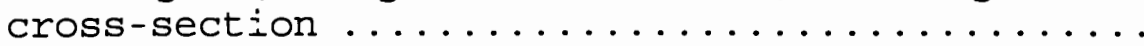

21. Location of $I-5$ and Oregon Slough bridges cross-section ...................... 76

22. I-5 and Oregon Slough bridges cross-section ... 77

23. Location of I-205 bridge cross-section. Contour lines represent 10 meter isopach on Holocene

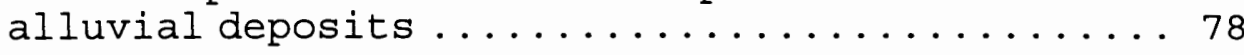

24. I-205 bridge cross-section .............. 79

25. Volume of sedimentary fill vs depth for the lower Columbia River basin .............. 84

26. Predicted sediment age-level curve for the lower Columbia River basin (boxes) compared to Grays Harbor sediment depth-age data (asterisks) .... 95 
LIST OF FIGURES (continued)

FIGURE

PAGE

A-1. Lanthanum vs. Samarium; Astoria and Longview

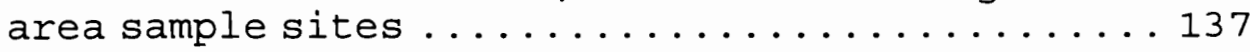

A-2. Lanthanum vs. Samarium; Portland area sample

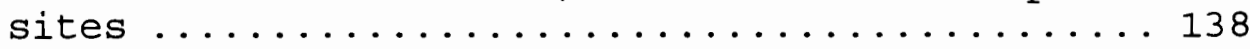

A-3. Cerium vs. Samarium; Longview and Astoria area

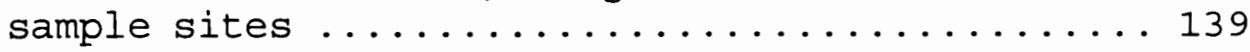

A-4. Cerium vs. Samarium; Portland area sample

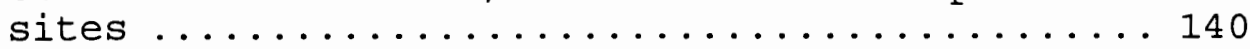

A-5. Cerium vs. Lanthanum; Longview and Astoria area

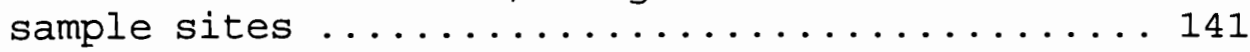

A-6. Cerium vs. Lanthanum; Portland area sample

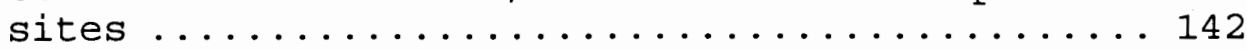

A-7. Cerium vs. Thorium; Longview and Astoria area sample sites ..................... 143

A-8. Cerium vs. Thorium; Portland area sample

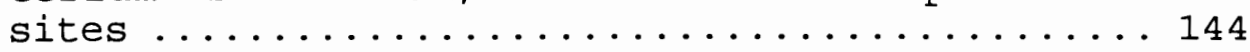

A-9. Hafnium vs. Thorium; Longview and Astoria area

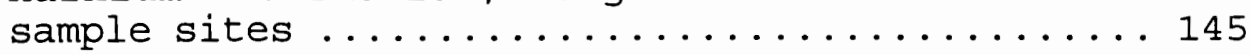

A-10. Hafnium vs. Thorium; Portland area sample

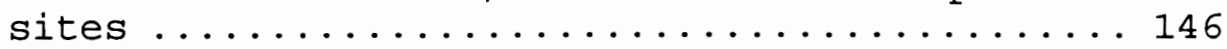

A-11. Scandium vs. Cobalt; Longview and Astoria area

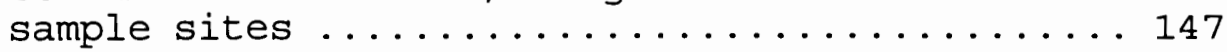

A-12. Scandium vs. Cobalt; Portland area sample

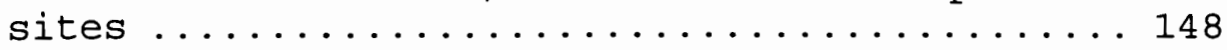

A-13. Cerium vs. Iron; Longview and Astoria area

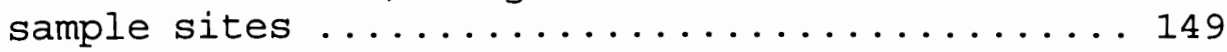

A-14. Cerium vs. Iron; Portland area sample sites ... 150

A-15. Scandium vs. Iron; Longview and Astoria area

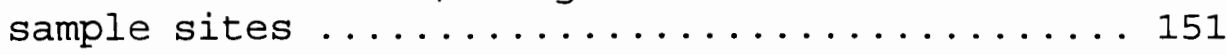

A-16. Scandium vs. Iron; Portland area sample

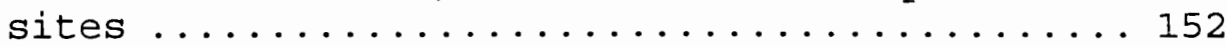


xiii

LIST OF FIGURES (continued)

FIGURE

PAGE

MAP 1 Lower Columbia River Isopach and Borehole Locations....................... $P$

MAP 2 Longview Area Isopach and Borehole Locations .. P

MAP 3 Mid Columbia River Isopach and Borehole Locations ..................... P

MAP 4 Portland Area Isopach and Borehole Locations .. P

$\mathrm{P}=$ in pocket of back cover. 


\section{INTRODUCTION}

Holocene transgressive sedimentary sequences along uplifted coastlines, such as the Cascadia margin, are generally poorly preserved due to the active tectonic development of the coastline. Yet, locally drowned river valleys that cut below the level of the coastal plain can preserve these transgressive sedimentary sequences. In the Pacific northwest the Lower Columbia River valley sediments record the local onset of marine transgression and the stratigraphic development of this basin during this transition.

The Columbia River is the largest fluvial system in the Pacific Northwest. While surface sediment deposition and distribution in historic times ( 1800 to the present) has been studied extensively (Sherwood and others, 1990; Sherwood and Creager, 1990), the subsurface (Holocene) depositional history of the basin has not had any comprehensive analysis. At present, data. for the Holocene fill exist in the form of geotechnical borehole data from both public and private industry records, but they have never been compiled into a single report. The late Quaternary incised valley of the Columbia River provides a narrow but very long basin for the infilling Holocene sediments. These Holocene sediments directly address questions about: A) the effects of historic 
damming of the upper river and its tributaries on sediment supply to the coastal beaches, i.e. is the basin a sink or source of littoral sediments (Phipps, 1992); B) the geometry and lithologic characteristics of the basin ground water aquifer (Frank, 1970; U.S.G.S., 1988), and C) geotechnical properties of the sedimentary fill for foundation and liquefaction susceptibility studies (Obermeier, in prep.).

Recently, several tephra occurrences have been identified within the Holocene fill of the lower Columbia River basin. Ken Robbins, (Portland, Oregon) has noted the occurrence of a deep tephra horizon, generally 45-70 feet below mean sea level (msl) from drill cores taken in the Portland and Longview, Washington areas of the Lower Columbia River basin. Thirty tephra samples were previously prepared and analyzed for source analysis by various investigators.

Pumice and ash that have erupted from vents in the Cascade Range have been widely used as chronostratigraphic horizon markers in the Pacific Northwest (Sarna-Wojcicki and others, 1991; Mullineux and Wilcox, 1980). Tephrastratigraphy and tephrachronology constitute a valuable correlation tool when used in combination, because the age of a well-dated tephra layer at an individual site can be extended to any other site where the same layer occurs. Once positive identification of the age and source for a particular tephra layer has been determined it then becomes a time horizon for correlation of other stratigraphic intervals over broad areas. 
Several methods have been employed to distinguish pyroclastic deposits from different eruptive sources. These include the use of refractive index of glass, bulk composition of both glass and mineral separates, and instrumental neutron activation analysis (INAA) of major and trace elements. Application of INAA allows for rapid characterization of ash by analysis of both rare earth and transition element concentrations. Several investigators (Randal, Goles, and Kittleman, 1971; Dudas, Harward, and Schmitt, 1973) have applied INAA for identification of volcanic ash deposits in the Pacific Northwest.

The objectives of this study are to compile available preexisting borehole data on the thickness and composition of Holocene fill in the LCRB into a single comprehensive report. The report contains: (1) A database for boreholes penetrating the LCRB sedimentary alluvial fill; (2) cross-sections showing the lateral distribution of both the Mazama ash layer and the late Quaternary sedimentary fill at selected localities; (3) isopach maps for the Holocene/late Pleistocene sedimentary fill; (4) documentation and detailed descriptions of the ash bed occurrences, including geochemical data, and the Holocene sedimentary deposits; (5) volumetric analysis of the late Quaternary sedimentary deposits, including calculations for prehistoric sediment deposition rates; and (6) predicted sediment age-level curve for the LCRB with estimates for the rates of sediment accumulation. 
The results of this study include an improved understanding of the Holocene sedimentary dynamics of the lower Columbia and lower Willamette River basins. The results allow us to construct the first detailed record of the stratigraphic development of the LCRB sediments. 


\section{BACKGROUND AND PREVIOUS WORK}

\section{THE COLUMBIA RIVER}

The Columbia River drainage basin covers an area of $660,480 \mathrm{~km}^{2}$ west of the North American continental divide. The eastern drainage basin extends from the Rocky Mountains of Southern British Columbia and the Northern United States to its southern margin along the northern divide of the Basin and Range province of Utah and Nevada and the high lava plateau of Oregon (Figure 1). The Cascade Range divides the drainage basin into eastern and coastal sub-basins with different climatic, hydrologic, and geologic characteristics (Simenstad and others, 1990). The western drainage basin includes the Cascade volcanic arc and forarc Willamette-Puget lowland of Oregon and Washington.

The Columbia River has the third largest flow of all the rivers in the United States. The modern mean annual riverflow is about $6,800 \mathrm{~m}^{3} \mathrm{~s}^{-2}$. The modern value shows a slight drop since 1878 (Simenstad and others, 1990) when riverflow measurements were initiated. Flow regulation from irrigation removal and engineered channel modifications have contributed to the decreased flow rate. Subsequent construction of hydroelectric dams has greatly depressed extreme flow (flood) rates (Sherwood and others, 1990). The Vanport flood of 1948 exceeded $28,600 \mathrm{~m}^{3} \mathrm{~s}^{-1}$ at The Dalles. The floods of 1972 and 


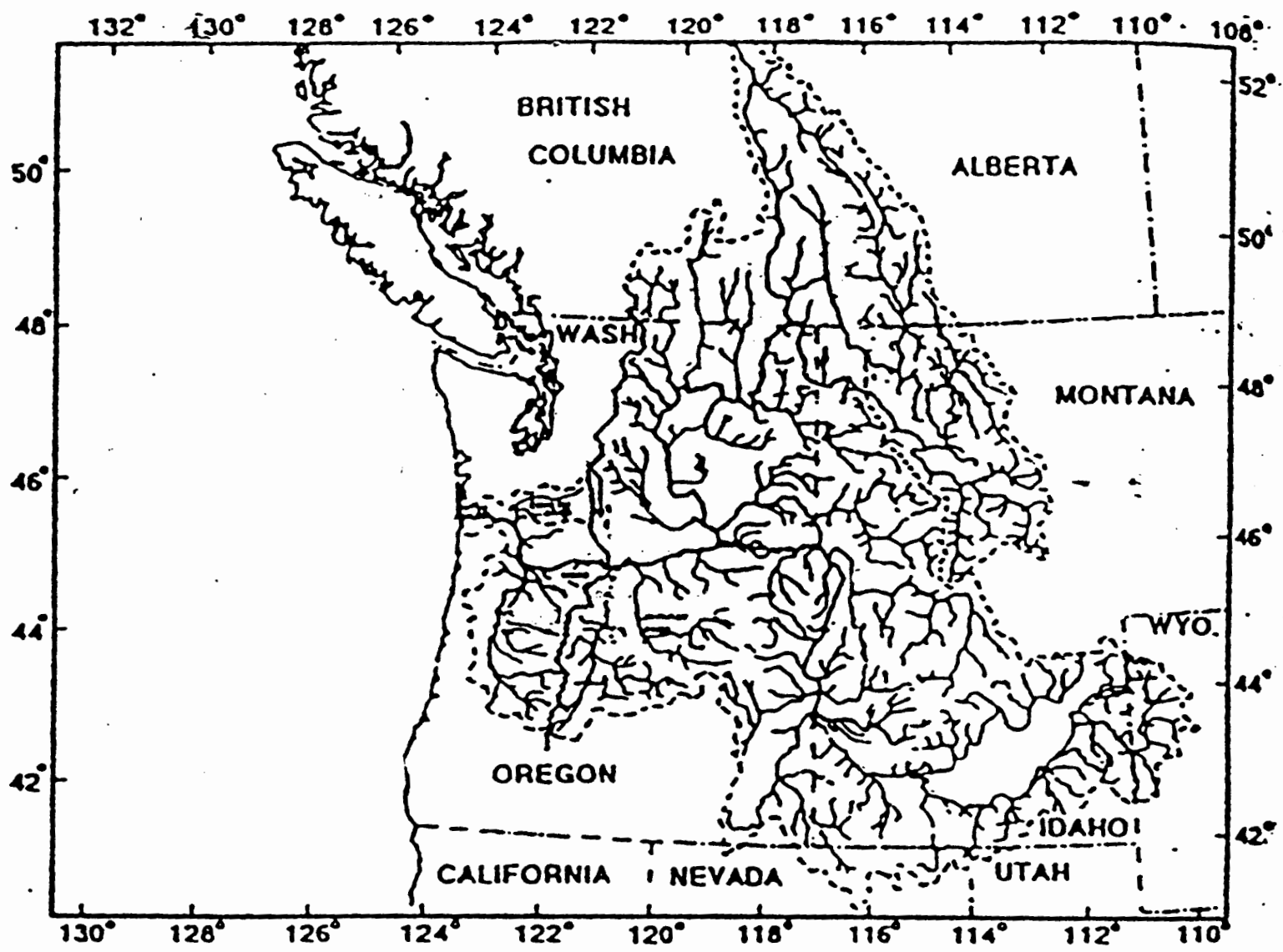

Figure 1. Map of the lower Columbia River drainage basin (Simenstad et al., 1990). 
1974 flowed at less then $17,600 \mathrm{~m}^{3} \mathrm{~s}^{-1}$ at The Dalles. The flow rate for these two floods were reduced by $12,318 \mathrm{~m}^{3} \mathrm{~s}^{-1}$ and $11,864 \mathrm{~m}^{3} \mathrm{~s}^{-1}$ respectively. Had there not been flow regulation, these two floods would have been as large as the Vanport flood event (Sherwood and others, 1990).

\section{HOLOCENE TEPHRAS}

The following information summarizes the eruptive history for active volcanic vents capable of producing large volumes of tephra in the Columbia River drainage basin area during Holocene time.

Table I (Sarna-Wojcicki and others, 1983) lists the age, ash layer designation, volcanic source area, and area of distribution, for Holocene ash layers of moderate to large volume in the western United States. For the volcanic source areas listed, four of the source vents appear capable of producing large volumes of tephra in the Columbia River drainage basin. The four vents are Glacier Peak, Mount Mazama (Crater Lake), Newberry volcano, and Mount st. Helens. Figure 2 (Sarna-Wojcicki and others, 1983) shows the extent of areal distribution for the tephra units from source vents listed in Table I. Due to the Iimited extent of tephra distribution for the Newberry volcano, it is not likely that this vent is a possible source for the extensive tephra deposits in the lower Willamette and lower Columbia Rivers. Therefore, the remaining three vents (Glacier Peak, Mount Mazama, and Mount st. Helens) 
TABLE I

VOLCANIC ASH LAYERS OF MODERATE TO LARGE VOLUME ERUPTED DURING LATEST PLEISTOCENE AND HOLOCENE TIME

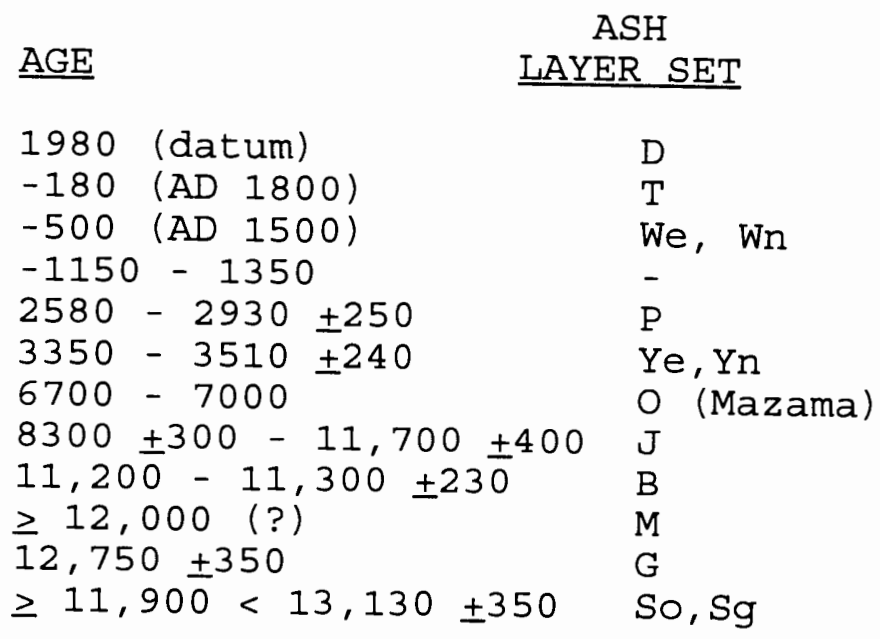

\author{
VOLCANIC \\ SOURCE AREA \\ Mt St Helens, Wa. \\ Mt St Helens, Wa. \\ Mt St Helens, Wa. \\ Newberry Volcano, Or. \\ Mt St Helens, Wa. \\ Mt St Helens, Wa. \\ Crater Lake, Or. \\ Mt St Helens, Wa. \\ Glacier Peak, Wa. \\ Glacier Peak, Wa. \\ Glacier Peak, Wa. \\ Mt St Helens, Wa.
}

Data from Sarna-Wojcicki and others, 1983. 


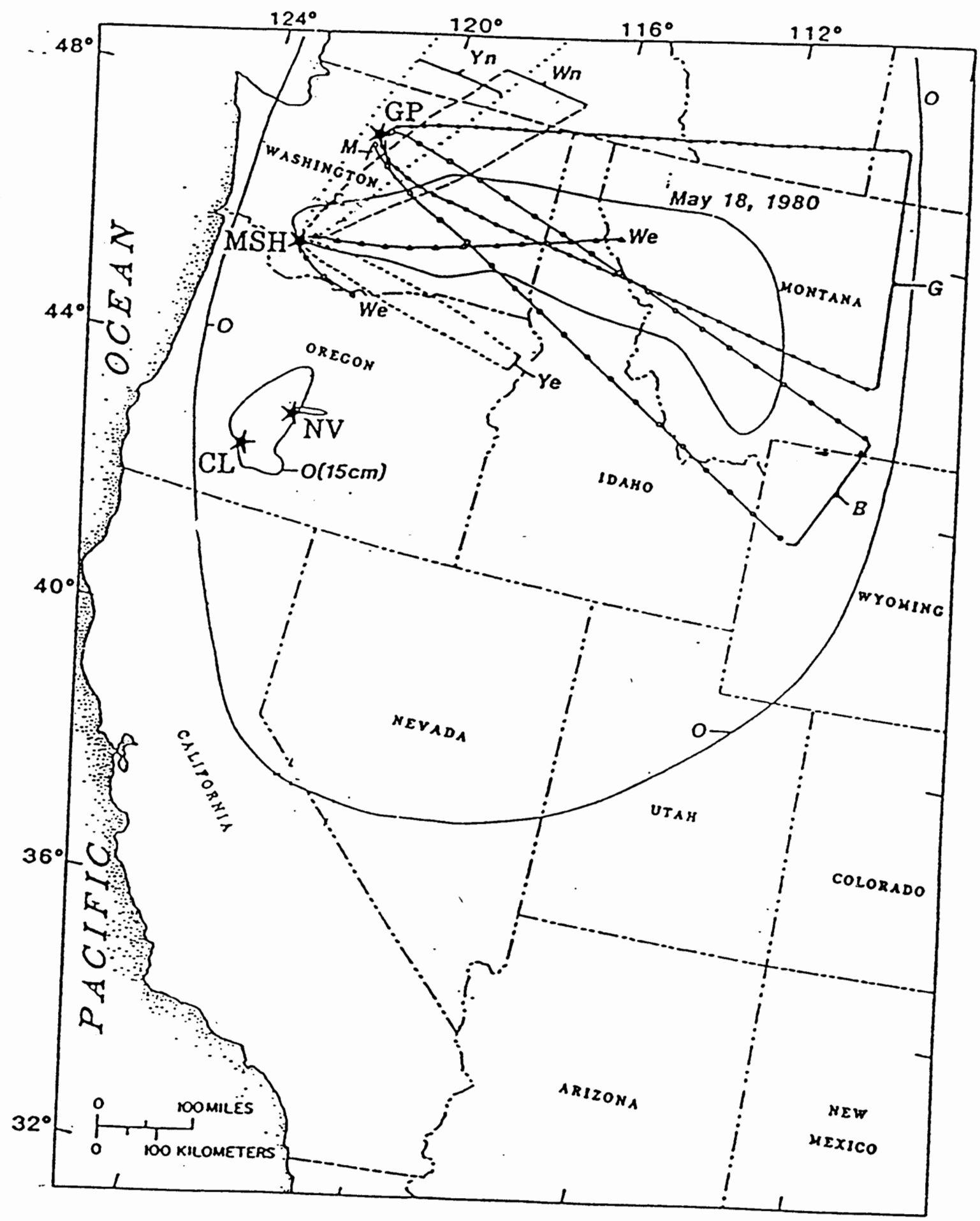

Figure 2. Areal distribution of latest Quaternary tephra units. Distributions shown for tephra units are probably minimal. Distribution shown for Mazama ash (layer O) is a composite of several lobes (Sarna-wojcicki et al.; in Wright, 1983). 
are potential sources for the suspect ash layer, because of their widespread distribution and/or Erequency of explosive activity.

Mount st. Helens has erupted nine major widespread tephra sets prior to 1980 (Crandell and Mullineaux, 1973, 1978; Mullineaux and others, 1975, 1978). Six of these sets were erupted within the last 12,500 years. From oldest to youngest they are sets; S, J, Y, P, W, and T (Table I).

Glacier Peak volcano in northern washington was active during a relatively short interval, from about 12,750 to 11,250 yr bp (Fryxel1, 1965; Mehringer and others, 1977; Porter, 1978). Three layers (G, M, and B) were spread over large areas east and south of the volcano (Porter, 1978).

The most widespread Holocene tephra layer in the United States is that of Mount Mazama. The tephra was erupted from a composite stratovolcano (named Mount Mazama by Williams, 1942) that stood at the present site of Crater Lake, Oregon.

The Mazama ash [(layer 0), Table I, Figure 3; Williams, 1942; Powers and Wilcox, 1964; Randle, Goles, and Kittleman, 1971; Bacon, 1981)] actually consists of several tephra layers presumably erupted within a relatively short period of time. Williams (1942) and Mehringer and others (1977) estimated the period to be short as three years, while Bacon (1983) suggests as long as 100 to 200 years for the sequence of eruptions. The minimum area covered by the Mazama ash (Figure 3) is nearly 1.7 million $\mathrm{km}^{2}$ (Mullineaux, 1975;). Bacon, (1988) reported an 

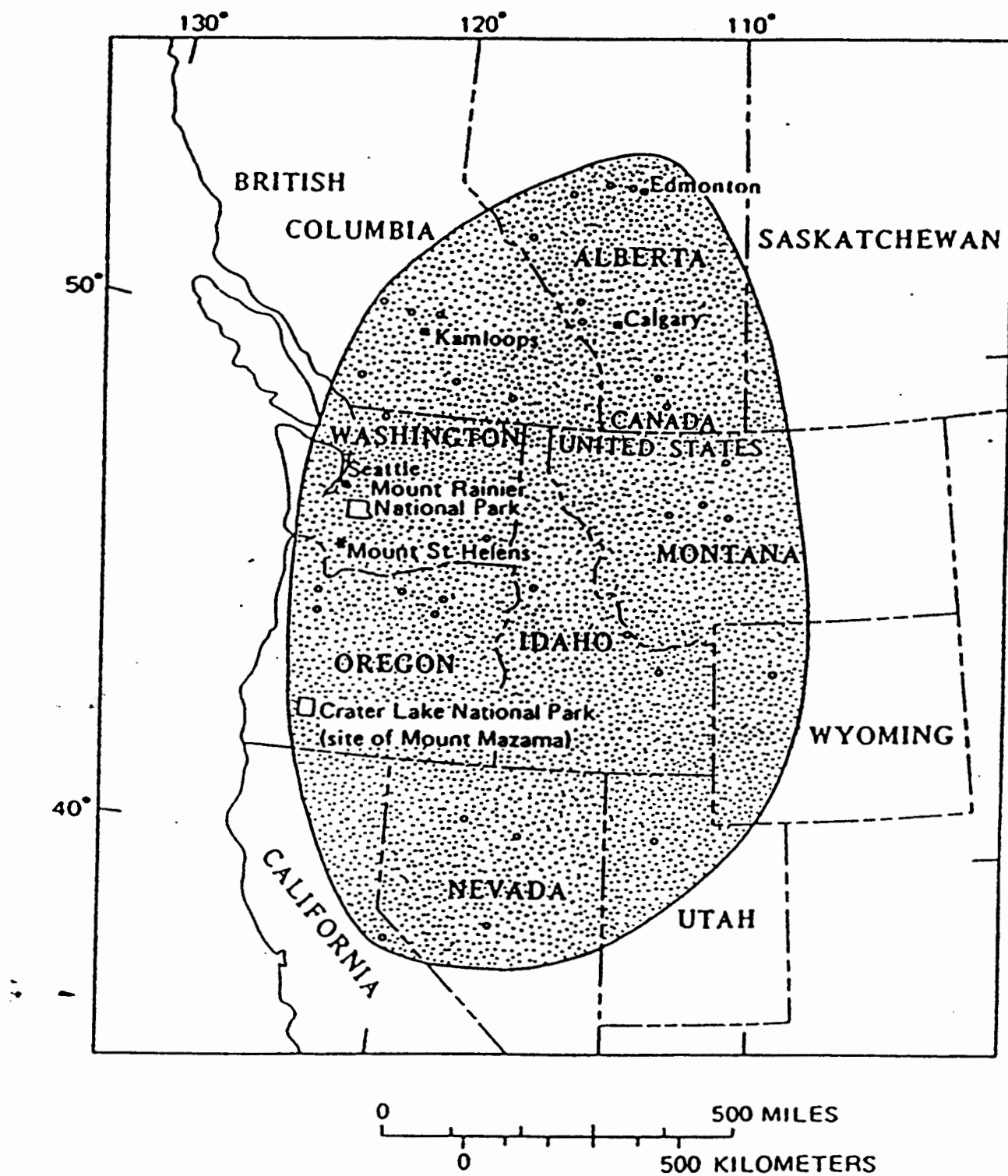

Figure 3. Minimum extent of Mazama ash (patterned) in the western United States and Canada. Circles mark sites where ash layer has been identified (Mullineaux, 1974; in Wright; 1983). 
age of $6,845 \pm 50 \mathrm{yr}$ bp from a weighted mean age of four analyses of charcoal from within or beneath ash flow and air fall deposits from the climactic eruption. Numerous investigators have reported ages ranging from 6600 to 7015 years bp for the Mazama tephra deposits.

\section{SEDIMENTARY GEOLOGY OF THE LOWER COLUMBIA RIVER}

The Columbia River drains geologically varied terrains which include igneous, sedimentary, and metamorphic rocks and extensive alluvial and eolian surficial deposits. The highest sediment yield is from the eolian Palouse soils of the Palouse and Walla walla River basins (Whetten, Kelly, and Hanson, 1969). Compared to other major rivers, the Columbia transports relatively little sediment (Sherwood and Creager, 1990). Estimates of the total suspended load for the river vary from 7 to $30 \times 10^{6}$ metric tons (mt) $\mathrm{Y}^{-1}$ (Van Winkle, $1941 \mathrm{a}, \mathrm{b}$; Judson and Ritter, 1964; Haushild et al., 1966; Jay and Good, 1978).

Simenstad and others (1990) reported that the river supplies about 9.7 million metric tons of sediment per year to the estuary, in the form of fine sand and coarse silt carried in suspension (Table II). Eight to 10 percent of the river sediment is very fine sand to medium sand, which is transported as bedload (Simenstad and others, 1990).

Calculations for present conditions by Sherwood, Jay, Harvey, Hamilton, and Simenstad (1990) indicate that the average sediment discharge under modern conditions is about 


\section{HINDCAST SEDIMENT DISCHARGE RATES AT VANCOUVER,} WASHINGTON, BY HISTORIC PERIOD

\begin{tabular}{|c|c|c|c|c|c|c|}
\hline \multirow[t]{2}{*}{ Period } & \multicolumn{2}{|c|}{ Sand $(>0.062 \mathrm{~mm})$} & \multicolumn{2}{|c|}{ Silt \& Clay $(<0.062 \mathrm{~mm})$} & \multicolumn{2}{|l|}{ Total } \\
\hline & $\begin{array}{l}10^{6} \text { metric } \\
\text { tons } y^{-1}\end{array}$ & $10^{6} \mathrm{~m}^{3} \mathrm{y}^{-1}$ & $\begin{array}{l}10^{6} \text { metric } \\
\text { tons } y^{-1}\end{array}$ & $10^{6} \mathrm{~m}^{3} \mathrm{y}^{-1}$ & $\begin{array}{l}10^{6} \text { metric } \\
\text { tons } Y^{-1}\end{array}$ & $10^{6} \mathrm{~m}^{3} \mathrm{y}^{-1}$ \\
\hline $\begin{array}{l}1868-1934 \\
1935-1957 \\
1958-1981 \\
\text { Entire Period }\end{array}$ & $\begin{array}{l}7.4 \\
4.8 \\
2.5 \\
5.9\end{array}$ & $\begin{array}{l}(7.0) \\
(4.5) \\
(2.5) \\
(5.5)\end{array}$ & $\begin{array}{l}7.5 \\
5.7 \\
5.1 \\
6.7\end{array}$ & $\begin{array}{l}(7.1) \\
(5.5) \\
(4.8) \\
(6.3)\end{array}$ & $\begin{array}{r}14.9 \\
10.4 \\
7.6 \\
12.5\end{array}$ & $\begin{array}{r}(14.0) \\
(10.0) \\
(7.2) \\
(11.8)\end{array}$ \\
\hline
\end{tabular}

\footnotetext{
Volume estimates assume uniform density of $2,650 \mathrm{~kg} \mathrm{~m}^{-3}$ and $40 \%$ porosity.
Data from Sherwood and others, 1990.
} 
$7.6 \times 10^{6} \mathrm{mt} \mathrm{y}^{-1}$, lower than historic values of $10-15 \times 10^{6} \mathrm{mt}$ $\mathrm{Y}^{-1}$ prior to dam construction (Table III).

Haushild and others (1966) indicate that the sand fraction in transport at Vancouver, washington, at river flows corresponding to the mean annual riverflow is $10-15 \%$ of the total sediment load. However, because most sediment transport occurs at higher river flows, the effective transport of sand is higher than implied by the $10-15 \%$ of total under mean flow conditions (Sherwood and Creager, 1990). U.S. Geological Survey (U.S.G.S.) calculations provided by Hubbel (in Sherwood and Creager, 1990) suggest that, on average, about $45 \%$ of the total sediment load is sand sized material (Sherwood and others, 1990). As noted above much of the finer sand travels in suspension during periods of high river flow.

Whetten (1966) performed extensive analysis of the sediment from the Columbia River. His findings indicate that sediments trapped behind upriver reservoirs reflect the plutonic, igneous, and metamorphic source rocks of the upper Columbia River basin and the eolian deposits found in the Palouse region of eastern Washington and the lower Snake River basin. The petrology of the modern lower Columbia River sands is predominantly volcanic rock fragments (basalt to dacite) and plagioclase feldspar (Sherwood and others, 1984) supplied in large part from the volcanic arc. Metamorphic and plutonic rock fragments are also common. Minor components of quartz, potassium feldspar, and micas reflect the plutonic and 
TABLE III

SEDIMENT DISCHARGE ESTIMATES FROM THE COLUMBIA RIVER

Estimate

$10^{6}$ metric

tons $\mathrm{y}^{-1}$

Water Year

$1910,1911-1912$

$1950-1952$

1969

$1964-1970$

$1964-1970$

$1878-1981$ $\underline{\text { Reference }}$

Van Winkle, 1914a,b

Judson and Ritter, 1964

USGS, unpublished data(f)

USGS, unpublished data(f)

Sherwood et al., 1990

Sherwood et al., 1990

(a) Snake and Columbia Rivers at Pasco, based on 2 years of incomplete data.

(b) Based on measurements at Beaver Army Terminal/Port Westward (RM-53) .

(c) Includes estimate of "unmeasured" suspended load and bedload, omits contribution of Willamette, Lewis, Cowlitz, and other tributaries below Vancouver wa.

(d) Same as (c), corrected for willamette River contribution using average total load of 1.2 million tons $\mathrm{y}^{-1}$ (based on USGS, unpublished data, WY 1963-1964).

(e) Based on hindcast 1878-1981.

(f) D. Hubbel, (Personal Communication, in Sherwood and others, 1990).

* Suspended load only.

Data from Sherwood and others, 1990. 
metamorphic source terrains to the east (Sheidegger and others, 1971). The dominant minerals in upper river sediments are quartz and feldspars. The dominant heavy mineral there is hornblende. The sediments in the lower reaches of the Columbia River reflect the contribution of andesitic volcanic materials from the tributaries draining the slopes of the Cascades. Downriver, the sediments contain increasing amounts of plagioclase feldspar and volcanic rock fragments and decreasing percentages of quartz and potassium feldspar. Pyroxenes become the dominant heavy minerals in the lower Columbia reaches (Whetten, Kelly, and Hanson, 1969). It is not known whether the relative contributions of the two different sources, i.e. the distal metamorphic belt or the proximal volcanic arc, changed in the LCRB during Holocene time.

Sherwood and Creager (1990) cite previous works by others (U.S. Army Corps of Engineers, 1933, 1960; Lockett and Kidby, 1961; Jay, 1984; Jay and Smith, 1990) that shows evidence that some of the sediments in the estuary may have been recently transported into the estuary from the adjacent nearshore and shelf regions. Studies of currents in the estuary have documented episodic landward flow predominance in the deeper portions of the entrance channels. Various physical and numeric models indicate net landward bottom flow and sediment transport through the entrance under low and moderate riverflow conditions (O'Brien, 1952, 1971; Herrmann, 1968; Hamilton, 1983, 1984, 1990; MCAnally, Brogdon, and Stewart, 
1983). These interpretations imply that the Columbia River may be a sink rather then a source of littoral sands in recent times.

The most comprehensive investigation of modern sedimentation in the lower Columbia River has been performed by Sherwood and Creager (1990) under the Columbia River Data Development Program (CREDDP). A brief summary of their results is as follows (Sherwood and Creager, 1990):

1. "The energy levels available for transporting sediment in the Columbia River Estuary are high relative to many of the estuaries of the world. These high energies are produced by large tidal range, large riverflow, and strong ocean wave activity near the mouth. The various circulations produced by the interactions of these three energy inputs together with the esturine density circulation frequently results in currents that are more than sufficient to move most of the sediment sizes (fine sand, silt and clay) found in the estuary".

2. "The ultimate source of the sediment for the estuary is the Columbia River which contributes a somewhat restricted range of sizes generally finer than 1.00 phi $(0.5 \mathrm{~mm})$. Local tributary and marine (littoral) sources contribute only minor amounts of sediment to the estuary. Evidence suggests that some marine sediments consisting of older or relatively recent Columbia River sediment and minor amounts of sediment from 
headland erosion along the oregon coast are being transported into the estuary" (Sherwood and Creager, 1990).

3. "The patterns of sediment distribution within the estuary are complex and reflect the variety of processes acting over various time scales. Most of the estuary reflects an even more restricted range of sediment size than is supplied by the river (Figure 4). The mean size of the estuary sediment is 2.50 phi $(0.117 \mathrm{~mm})$ or fine sand. Sediment of this size is highly mobile" in strong currents, found in the primary channels of the estuary.

4. "Fine sediment that is normally transported in suspension comprises only a small percentage of the sediment deposited in the estuary. Fine grained sediments (silt and clay) are found in the peripheral bays, swamps, marshes, and minor, inactive channels, especially Cathlamet, Baker, and Youngs Bays. Ephemeral deposits of fine sediment also occur in the channels of the central estuary".

5. "Inspection of the distribution of rip-up clasts, fine sediment deposition, and the excursion of the turbidity maximum suggests that suspended sediments concentrated in the turbidity maximum may be mixed into upper layers of the water column and advected either out of the estuary or into peripheral bays. In the latter instance, currents would be insufficient to resuspend the sediment if it settles to the bottom. Deposition of fine sediments in the main channels occurs intermittently beneath the turbidity maximum, but does 


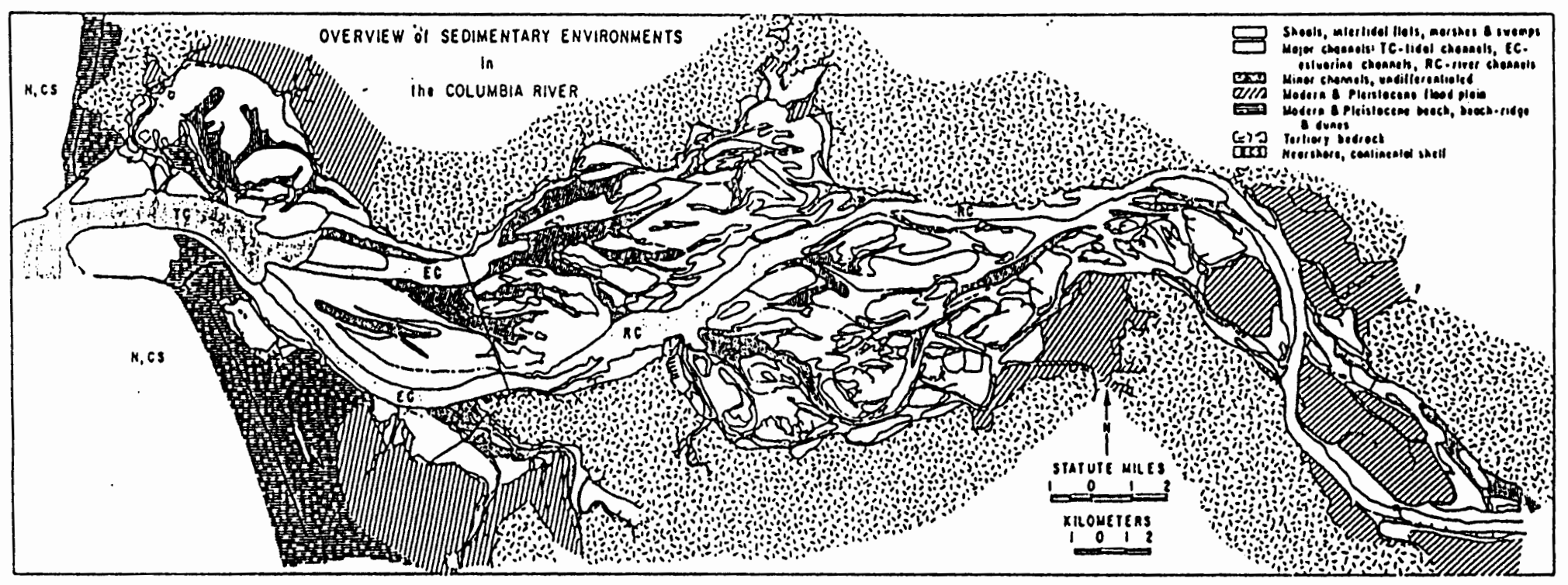

Figure 4. Sedimentary environments of the Columbia River estuary (Sherwood and Creager, 1990). 
not result in a long-term accumulation of fine material in the estuary, due to subsequent scouring by strong currents".

STRUCTURAL DEVELOPMENT OF THE STUDY REGION

The Pacific Coast of the northwestern United States is located on an active continental margin. The study region lies at the margin between the North American continental plate and the subducting Juan de Fuca oceanic plate (Figure 5). The results of this collision have been active tectonic and volcanic activity in the Pacific Northwest region for at least the last 55 million years (Lowry and Baldwin, 1952). The regional tectonic characteristics exert both direct and indirect effects on the physical processes within the lower Columbia River basin, and controls the overall sedimentary Eramework on a geological time scale.

The present location of the lower Columbia River is largely the result of late Paleogene-early Neogene tectonics in what is now northwest Oregon and southwest washington. Approximately $25^{\circ}$ of clockwise rotation (post oligocene) occurred in the northern Oregon Coast Range, possibly in small blocks, as a result of collision with the North American plate (Simpson and Cox, 1977; Magill and Cox, 1981; Wells, 1988). Much of the rotational $E-W$ shearing took place in the vicinity of the present lower Columbia River, roughly paralleling the pre-Neogene structure. Coastal compression in the Northwest during the last 5 million years has resulted in structural 


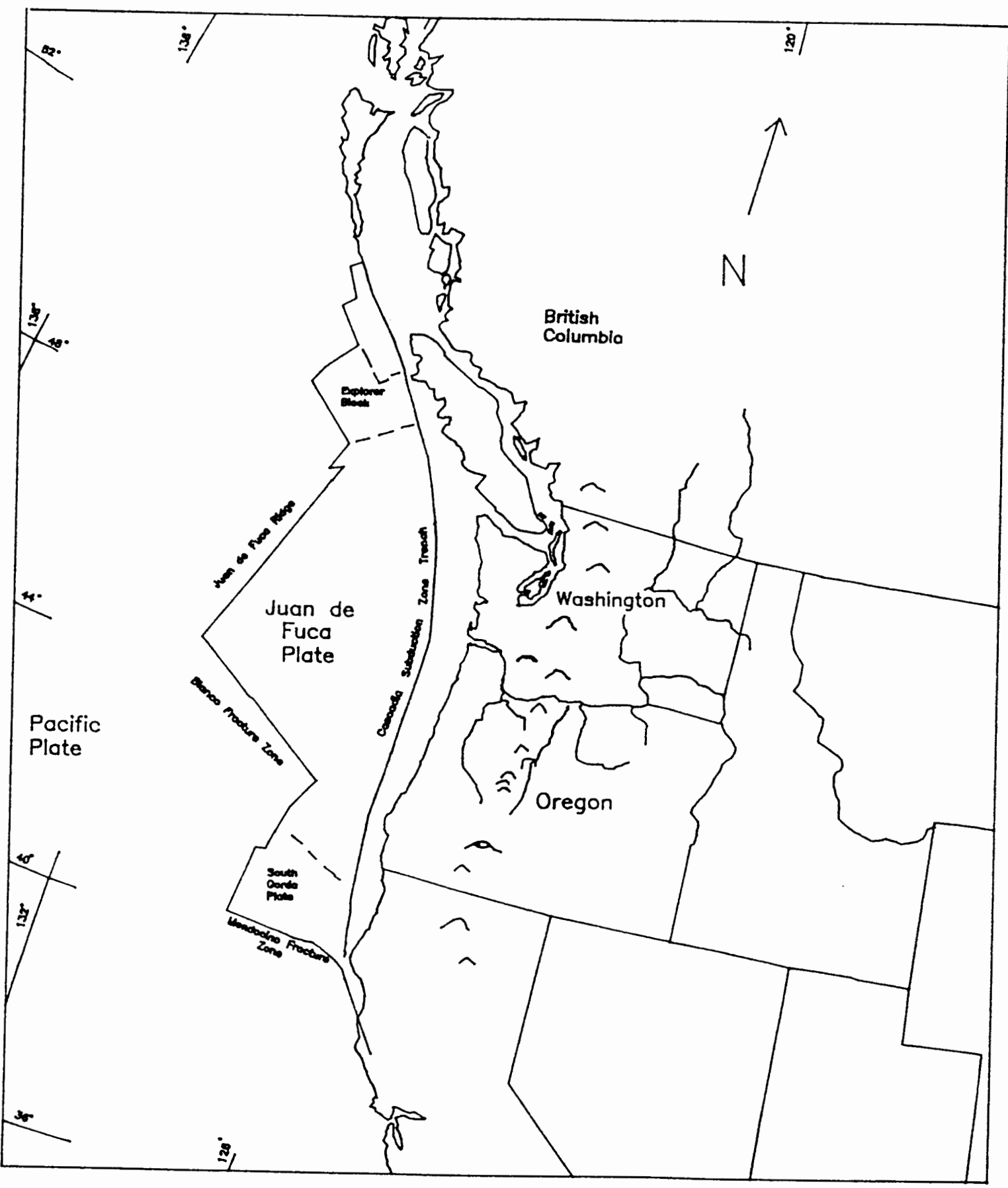

Figure 5. Tectonic setting of the Oregon and Woshington Coast showing the Cascadia Subduction Zone trench, the Juan de Fuca Plate, and smaller plate segments at each end. The Cascade volcanic arc parallels the trench about $250-300 \mathrm{~km}$ inland. 
deformation (folds) and extensive faulting of the bedrock geology. The resulting dextral wrench fault zone has produced two sets of fault trends. Most of the lower Columbia River and its major tributaries are controlled by these major faults. Generally, the northwest trending faults strike N36W and the conjugate (antithetic Reidel shears) northeast faults occur at nearly $90^{\circ}$ offset to the northwest faults (Beeson and others, 1991; Yelin and Patton, 1991). During the period of rotation, ongoing subduction and island arc volcanism continued to shape the continental margin in the vicinity of the Lower Columbia River. The Cascade volcanic arc trends parallel to the Cascadia subduction zone. The arc occurs about 250 to $300 \mathrm{~km}$ inland from the trench axis.

\section{BEDROCK STRATIGRAPHIC DEVELOPMENT}

Bedrock formations in the LCRB consist of deep to shallow water and subaerial sedimentary rocks intercalated with flood basalt and volcanic rock sequences going back 50-60 million years before present. The Cascade Range volcanos began developing approximately $35 \mathrm{ma}$, and have been a major source terrain for sands transported through the lower Columbia River.

The bedrock stratigraphy directly under the Columbia River entrance area has not been reported. By projection of bedrock units mapped in the Astoria 15' Quadrangle by Schlicker and others (1972), it appears that the study area is 
underlain by an undifferentiated sequence of sedimentary rocks of Oligocene to middle Miocene age. These beds are estimated to be approximately 5000 feet thick and consist of thin bedded to massive tuffaceous siltstone and claystone with lesser amounts of sandstone and shale locally. Tertiary basalts also may occur at depth (Neim and Neim, 1985).

Several wells have been drilled in the Clatsop Plains area south of the south jetty within a few miles of the study area (Frank, 1970). Near the surface, these wells encountered a variety of unconsolidated dune, beach, and shallow marine sands interbedded with alluvium, all of probable late Pleistocene to Holocene age. These young unconsolidated deposits extend to depths between 250 and 300 feet below sea level and rest unconformably on a semi consolidated sandy unit that extends to depths of approximately 400 feet below sea level. This second unit was tentatively identified as the Astoria Formation by Frank (1970), but subsequently called upper Miocene sandstone by Schlicker and others (1972). This unit is typically a buff-colored, medium to coarse grained, semi consolidated sandstone of marine origin. The upper part of the Oligocene-Miocene beds are reported to include the Astoria Formation ( Frank, 1970).

Late Pleistocene deposits that are common in smaller esturine river valleys in the Pacific Northwest, such as the Coquille Formation (Snavely, 1948; Baldwin, 1981), are not 
well preserved subaerialy in the lower reaches of the columbia River estuary.

By early Miocene the present Coast Range location was uplifted, restricting marine sedimentation to isolated embayments (Niem and others, 1987). In early Pliocene time, the uplift yielded a complete transition to terrestrial deposition in the lower Columbia region. Repeated filling/downcutting of the ancestral Columbia River flood basalts (Beeson and Moran, 1979) demonstrates the maintenance of the antecedent river valley through mid-Miocene time. From the mid-Miocene to Pliocene, fluvial sediments (Sandy River Mudstone and lower Troutdale Formation) were deposited by the Columbia River in the transtensional Portland basin (Trimble, 1963; Beeson and others, 1985; Swanson, 1986) and possibly further downriver. The sandy River mudstone and Troutdale Formations represent a large thickness of lacustrine and fluvial sediments derived from east of the study area. Differential uplift of the Coast Range after 2 ma, terminated Troutdale deposition (Tolan and Beeson, 1984) and has continued to the present.

The most recent stratigraphic information for bedrock lithologies of the Columbia River basin in the vicinity of the Coast Range is derived from the Champlin well (Appendix B, Map ID\# 1292), located just south of Clatskanie Oregon, on the flood plain of the Columbia river at about river mile 50 . From the surface the well penetrated 300 feet (91 meters) of 
unconsolidated Holocene sands and silts, followed by 315 feet (96 meters) of coarse grained sediments interpreted by the author to be equivalent to the Bretz flood deposits and the underlying Quaternary Troutdale and Sandy River Mudstone Formations. At 615 feet below mean sea level (msl) the upper contact with underlying Gobel (?) volcanics was encountered. Below the Gobel basalts Tertiary sedimentary rocks were reported below depths of -1100 feet subsurface, along with interbedded volcanic strata. Volcanic material is the dominant Iithology to the end of the drill hole at $-5700 \mathrm{msl}$ elevation.

In the upper portions of the study area near Portland Oregon, the oldest rocks exposed in the Columbia River basin are the Skamania Volcanics. These rocks display limited exposure at Ione Reef and along the south shore of Lady Island near Camas Washington. The Columbia River Basalt Group (CRBG) overlie the Skamania Volcanics and are exposed in numerous small bedrock knobs and along the steep valley walls throughout the study area. The Miocene CRBG flows were erupted from 17 to 6 ma from fissures in northeast Oregon, eastern Washington, and western Idaho (Beeson and others, 1989). The basalts flowed west through the ancestral Columbia River valley filling topographic lows such as the transtensional Portland basin. The Columbia River basalts have recorded nearly continuous tectonic activity through the Tertiary (Beeson and others, 1989). The basalt flows crop out primarily at the margins of the Portland basin. Overlying the CRBG is a 
thick section, up to 1,200 feet (366 meters), of Pliocene to Pleistocene fluvial sediments. The Sandy River Mudstone is the lower member of this section. It is composed of mudstone, claystone, siltstone, and very fine sands. The Sandy River Mudstone has been interpreted by Trimble (1963) to represent lacustrine or overbank deposits. Above the Sandy River Mudstone is the Troutdale Formation. The Troutdale Formation consists of two distinct members (Tolan and Beeson, 1984). The lower member consists of pebble and cobble conglomerates of predominantly Columbia River Basalt along with clasts of quartzite and micaceous sandstones interpreted to be derived from the ancestral Columbia River and is confined to an area near the present Columbia River channel (Tolan and Beeson, 1984). The upper member is composed of locally derived pebble and cobble vitric sandstones with basalt conglomerate interbeds (Tolan and Beeson, 1984). Interbedded with the Troutdale Formation are the Boring lavas. These Pliocene to Pleistocene lavas are high alumina basalt that originated from 90 vents throughout the Portland and Vancouver area (Allen, 1975).

During latest Pleistocene time catastrophic flood debris was deposited in the Portland basin (Bretz, 1928, Bretz, 1969). The floods were the result of glacial melt water outbursts from glacial Lake Missoula in western Montana (Waitt, 1985). Waitt (1985) determined that a minimum of 40 , and most likely greater than 60 , flood events inundated the 
Columbia River Valley. These successive flood events probably resulted in extensive scouring of the Columbia River valley. Both coarse and fine grained sediments were deposited upon much of the backflooded Portland basin and Willamette valley floors. The narrows at Kalama, Washington restricted the outflow from the Portland basin, but downstream of Kalama the floods diminished, possibly decreasing to $0 \mathrm{~m}$ elevation (relative to modern sea level) at Astoria (Allen, 1986). Allen (1986) indicated that the over-steepened northeast face of Nicolai Mountain, east of Clatskanie Oregon, represents the furthest downriver geomorphic expression from the Bretz floods. The actual depths of the flood-scoured, pre-Holocene contact between Kalama and Astoria are unknown, but they are unlikely to be deeper then the minimum sea level of -390 ft ($120 \mathrm{~m})$ below modern sea level, that prevailed during the end of the last glacial stage (Bloom, 1983). Waitt (1985) estimated that the age of the last catastrophic flood event occurred about 12,700 years ago. This date is based on the $11,250 \pm 250$ years Glacier Peak ash layer $G$ which overlies deposits of one huge flood but not those of the smaller, late stage floods that followed deglaciation of the Columbia River valley. The nature of the sediments back filling the presumed flood scour basins in the pre-Holocene Columbia River channel have not previously been documented. 


\section{SEA LEVEL CHANGES}

Along most of the worlds coastlines sea level has been rising throughout the Holocene. The geologic community defines the beginning of the Holocene period at 10,000 years bp From a glacially lower level of about $120 \pm 60$ meters below present sea level (Bloom, 1983), the sea surface rapidly rose in reciprocal proportion to the volume of the shrinking late Wisconsin glacial ice sheets and mountain glaciers. By 10,000 years bp, the area of former ice cover was reduced to about $50 \%$ of its maximum extent during the late wisconsin glaciation (Bloom, 1983). The Holocene has been a period characterized by global marine transgression, although the rates and amounts have varied from place to place. Geological evidence suggests that global sea level rose at a relatively rapid rate of at least $10 \mathrm{mmy}^{-1}$, and subsequently slowed to the present rate of 1-2 mm $\mathrm{Y}^{-1}$ about 5,000 years ago (Bloom, 1983).

Along the Pacific Coast one of the well studied estuaries is San Francisco Bay, California. Its entrance near the Golden Gate is 60 to $70 \mathrm{~m}$ below present sea level and was probably entered by the sea about 11,000 to 10,000 years ago (Atwater and others, 1977). By 8000 years bp, most of the present Bay area was flooded. Prior to 8,000 years bp, the submergence rate was about $2 \mathrm{~cm}$ per year (Figure 6). Since 6000 years bp, the rate has been only one tenth as fast, about 1 to $2 \mathrm{~mm}$ per year (Atwater and others, 1977). 


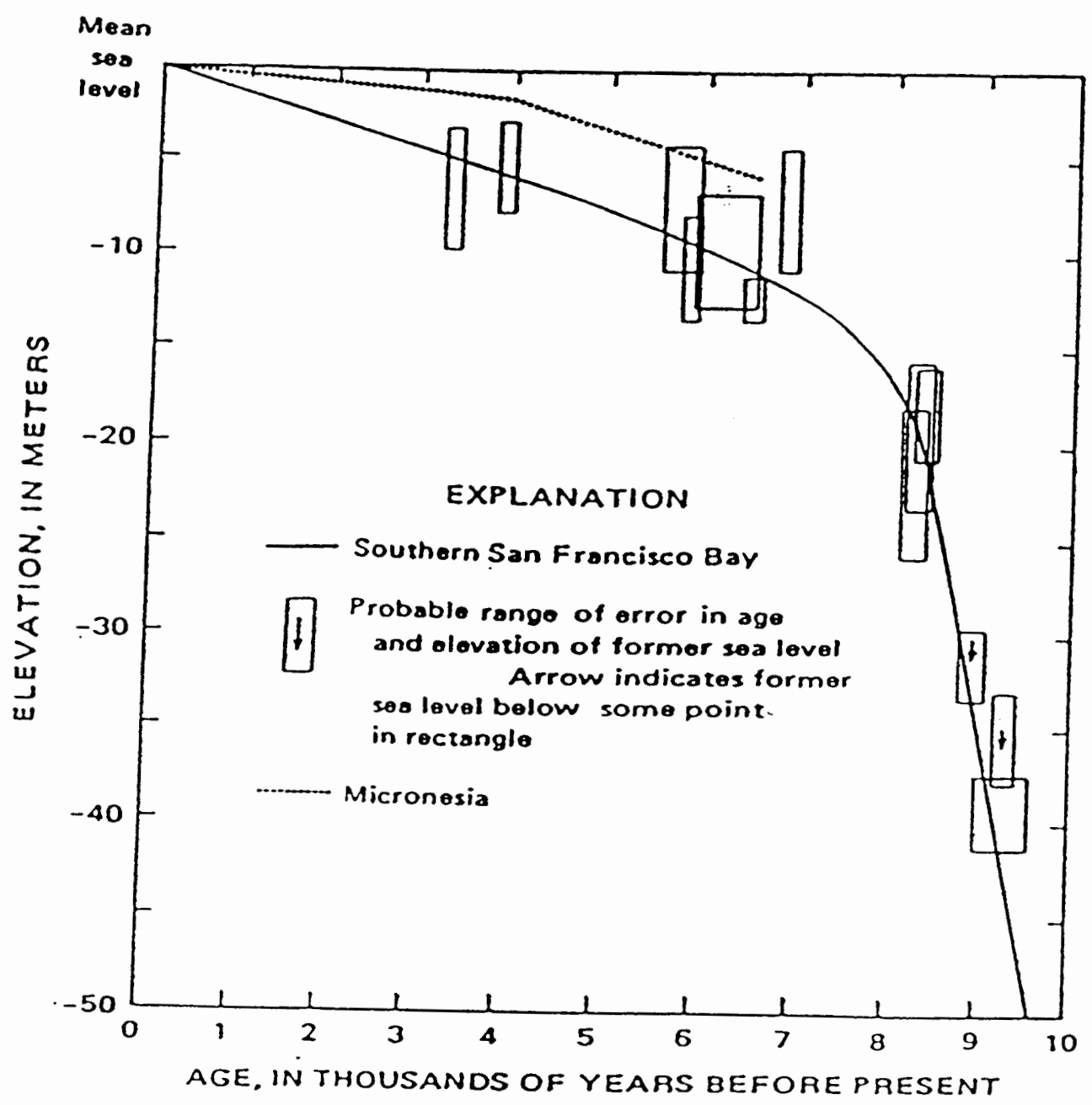

Eigure 6. Holocene sea-level history for southern San Francisco Bay (Atwater et al., 1977). 
Glenn (1978) reports radiocarbon dates in a core from Tillamook Bay that suggest similar rates for coastal Oregon (Figure 7). Studies at Alsea Bay, Oregon (Peterson and others, 1984), and at Grays Harbor, Washington (Peterson and Phipps, 1992) showed that sediment infilling rates in the active margin estuaries decreased substantially following the declining rate of eustatic sea level rise in mid Holocene time. Figure 8 (Peterson and Phipps, 1992) shows a sediment level curve for Grays Harbor that clearly displays the rapid sedimentation rate $(1.2 \mathrm{~cm} / \mathrm{yr})$ that corresponds to the early Holocene rapid sea level rise followed by a sharp decrease in the sedimentation rate $(0.5 \mathrm{~cm} / \mathrm{yr})$, particularly after $5.5 \mathrm{ka}$, which is in accord with the declining rate of sea level rise.

Rankin (1983) considered sea level fluctuations as controlling factors in the beach ridge and dune development in the Clatsop Plains region immediately south of the mouth of the Columbia River. His analysis was based on radiocarbon dating of developed peat layers within the Clatsop Plains dune complex. Figure 9 is a sea level plot of radio-carbon dates compared to sea level curves from various sources. Rankin (Figure 9) reported that sea level fluctuations consisted of a sharp rise until 2300 years bp followed by a gradual fall until 1400 years bp and then reversed to show a gradual rise to the present. However, local tectonics are now thought to dominate the short period sea level fluctuations (350-500 years) along the Pacific northwest coast. This coastline is 


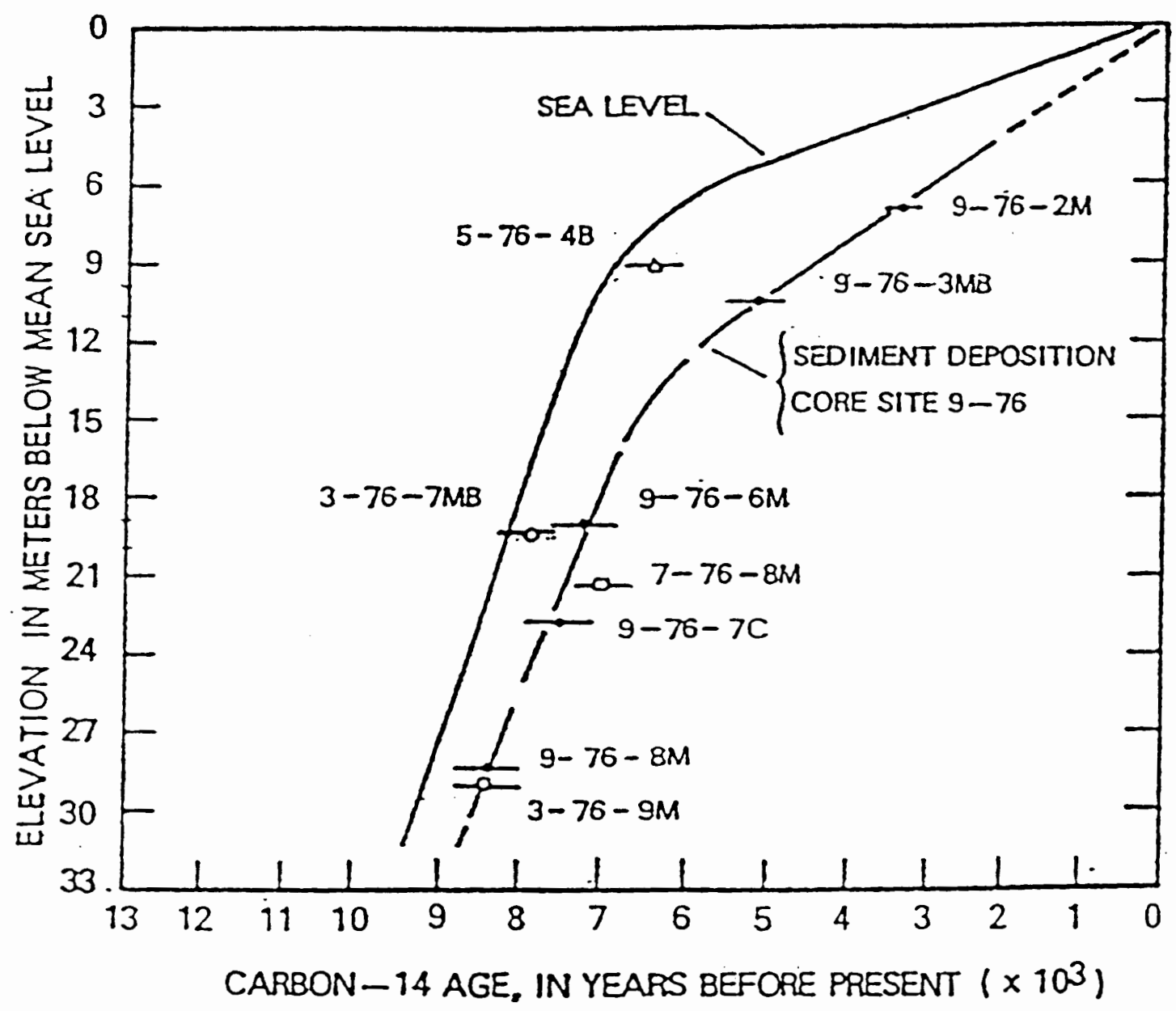

Eigure 7. Generalized curve of world-wide sea-level rise (Kraft, 1971) and curve of sediment deposition from Tillamook Bay, Oregon (Glenn, 1978). 
GRIYS HARBOR BASIN. WASHINGTON

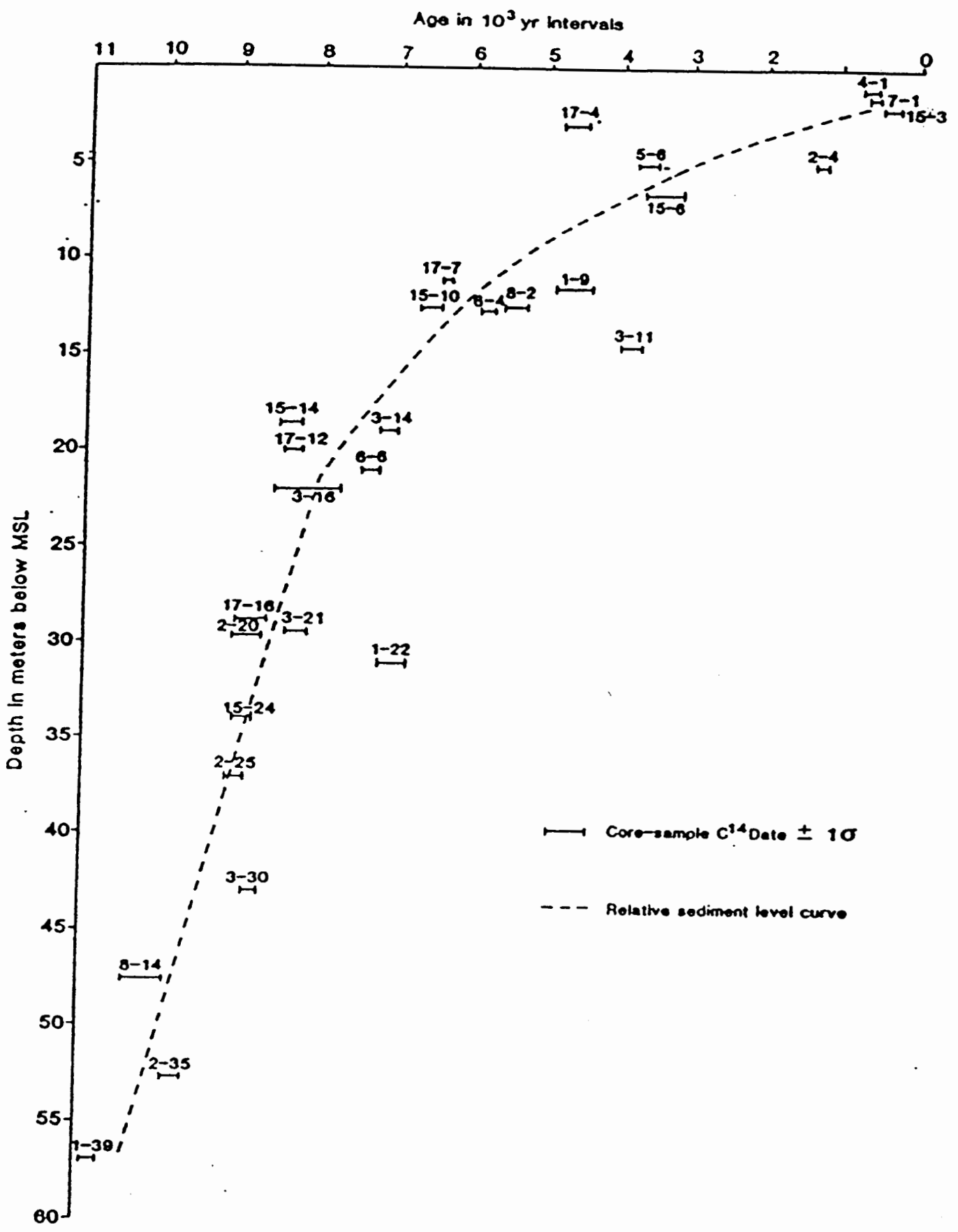

Figure 8. Sediment level curve for Grays Harbox Washington (Peterson and Phipps, 1992). Note the abrupt decrease in sediment accumulation about 7,000 years ago. 


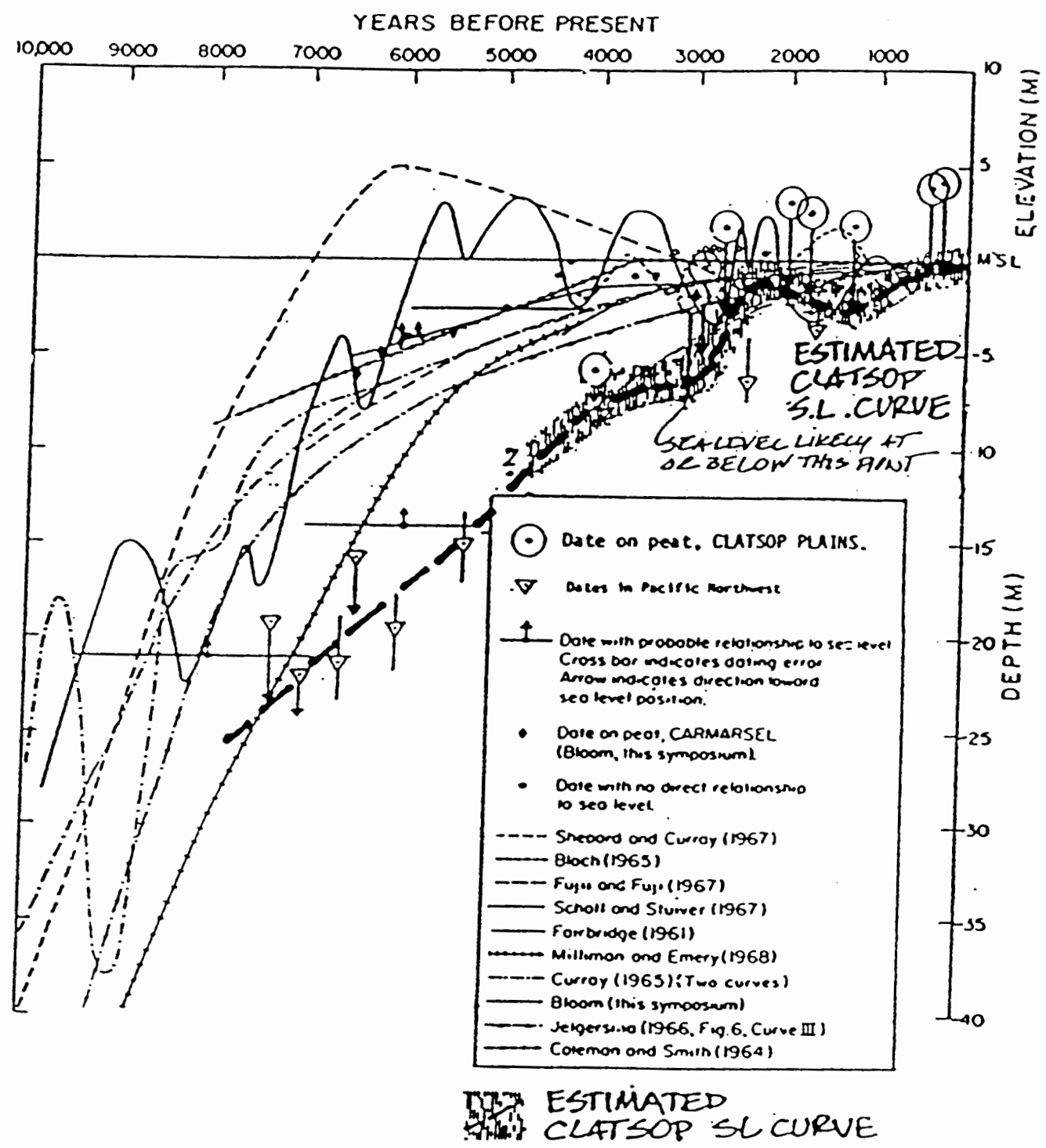

Figure 9. Sea level plot of carbon dates from the clatsop plains (Rankin, 1983) compared to sea level curves from various sources, (modified from Curry, Shepard, and Veech, 1970 and Bloom, 1977). 
known to have experienced megathrust earthquakes (Darienzo and Peterson, 1990).

Since 1940 the average sea level around the United States has been rising at a rate of about $1.5 \mathrm{~mm} \mathrm{Y}^{-1}$ (Hicks, 1978). However, sea level has not continued to rise along the oregon and Washington coast adjacent to the Columbia River estuary in historic times. Modern tectonic uplift of coastal Oregon and Washington is producing in a lowering of relative sea level (Hicks, 1972). Geodetic levelling from 1904 to 1974 (Ando and Balazas, 1979) and tide gauge data from 1946 to 1974 (Hicks, 1972, 1978; Chelton and Davis, 1982) both suggest that sea level in Astoria has been falling since the turn of the century. The estimated rates of sea level fall ranges between 0.01 and $0.11 \mathrm{~cm} \mathrm{Y}^{-1}$ depending on method and period considered; the higher and probably more reliable estimate $\left(0.11 \mathrm{~cm}^{-1}\right)$ is that of Chelton and Davis (1982). The mechanisms for this tectonic uplift are the result of interseismic strain accumulation associated with interplate coupling between the Juan de Fuca Plate and the North American Plate in the Cascadia subduction zone (Darienzo and Peterson, 1990; Atwater and others, 1987). The last dislocation of the central Cascadia margin occurred about 300 years ago and resulted in 1-2 meters of subsidence at the mouth of the Columbia River (C.D. Peterson, personal communication, 1993).

A study of beach sediments along the southern washington coast by Ballard (1964) indicates that the net longshore drift 
of sands on the inner shelf between the Columbia River and Grays Harbor is to the north. The broad fan shaped pattern of bottom contours north and west of the outer end of the north jetty called Peacock Spit is undoubtedly formed from sediments that have been carried northward, possibly from dredge spoils deposited offshore of the Columbia River entrance. 
STUDY AREA

The study area (Figure 10) includes the lower Willamette River basin (Portland area to the mouth) and lower Columbia River basin (LCRB) (Troutdale, Oregon to Cape Disappointment, washington). The area is defined as the tidally influenced regions of the lower Columbia River and Willamette basins that had the Mazama ash bed deposited in the Holocene sedimentary alluvium, including the adjacent floodplain. The eastern boundary is at the mouth of the sandy River near river mile 120. The southern boundary is about 200 meters upriver from the Fremont Bridge crossing of the willamette River in Portland. The western boundary is defined by a vertical plane extending across the mouth of the river from cape Disappointment, Washington to the northwestern extent of the uplifted marine terrace deposits near warrenton oregon. Figure 10 shows the locations mentioned in text.

Depth profiles extend down to at least the elevations of the Mazama ash horizon (generally -70 to -45 feet, or -21 to 14 meters msl,, and are extended to the pre-Holocene contact in the areas where this data is available. 


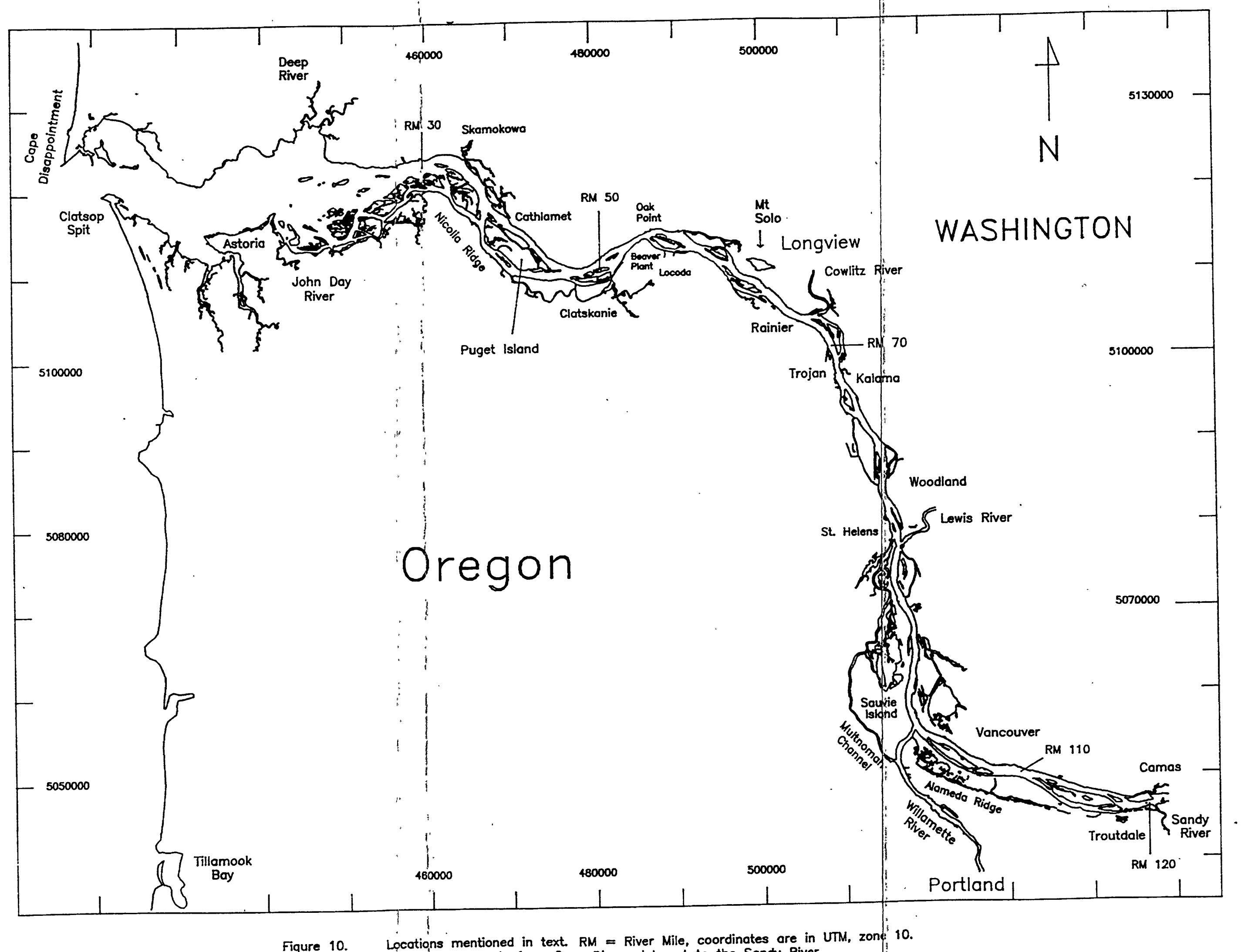

Figure 10. Locations mentioned in text. RM $=$ River Mile, coordinates ore in
Study areo extends from Cope Disappointment to the Sandy River. 


\section{METHODS OF INVESTIGATION}

This investigation includes a compilation of existing borehole records and reported occurrences of a key tephra layer bed in the Holocene fill of the lower Columbia River. Analysis of facies types and their stratigraphic distributions are derived from drill core logs within the lower Columbia River flood plain and its adjacent tributaries. The dating and stratigraphic correlation of the key ash beds in the Holocene fill are established by tephra chronologic methods (discussed below). These marker beds are used in conjunction with extrapolated sea level curves to predict a sediment depth-age curve for the lower Columbia River sedimentary fill.

TEPHRA CORE DATA IN THE COLUMBIA RIVER VALLEY FILL Core data for many of the Mazama ash occurrences were derived from Ken Robbins, a retired engineer for Dames and Moore Inc., of Portland, Oregon. Ken noted from borehole logs 73 occurrences of the target ash bed in the Portland area and 72 occurrences in the Longview, Washington area. I have noted an additional $50+$ occurrences of this ash horizon mostly from areas outside of the Portland and Longview regions, with most of these occurring in the lower estuary region. 


\section{TEPHRA SOURCE ANALYSIS}

For this study nine samples of tephra were collected from Eive different drill core borings in the lower estuary. Three of the borings are from the oregon Department of Transportation (ODOT) John Day River Bridge project near Astoria, Oregon. Another boring is located approximately 0.5 $\mathrm{km}$ east of the John Day River Bridge project in the flood plain of the John Day River. The fifth arill core is from a proposed bridge site on Holbrook slough in Warrenton oregon. Appendix A contains the geochemical data used in this study.

Detrital material and organics were removed from each sample (except sample NG-9), and the sample was subjected to the following laboratory procedures: 1) all visible grains larger then Eine sand size were removed using stainless steel tweezers; 2) the samples were ground to a powder using a washed porcelain mortar and pestle; 3) samples were transferred to $200 \mathrm{ml}$ glass beakers and deionized water was added and mixed to produce a slurry; 4) the slurry was transferred to porcelain petri dishes and dried overnight in a I ab oven; 5) the dried samples were then prepared with $\mathrm{H}_{2} \mathrm{O}_{2}$ to remove the organic material and placed in a vent hood overnight; 6) samples were then placed on a hot plate for 30 minutes to drive off vapors; 7) after heating the samples were again mixed with deionized water to aid in the transfer to plastic centrifuge containers; 8) the samples were then centrifuged to further separate out any detrital material that 
remained; 9) after centrifuging the samples were redried overnight and ground to a powder the following morning with a porcelain mortar and pestle.

An approximate one gram split from each sample was placed into clean $2 / 5$ dram polyvials and weighed to 0.0001 gram with a Mettler HIOT balance. To reduce the effects of varying geometries with respect to the gamma ray detector, each sample was filled to approximately an equal volume. The polyvials were then heat sealed and placed in 2 dram polyvials for irradiation.

The samples were exposed to a flux of $2.0 \times 10^{12}$ neutrons $\mathrm{cm}^{-2} \mathrm{sec}^{-1}$ at $250 \mathrm{KW}$ for one hour. Gamma ray spectra were obtained using a high purity Germanium coaxial photon detection system. Initially, 4-5 days (1000 sec live time), and again 12-16 days (3000 sec live time) after irradiation. Elemental concentration peaks and percent errors were obtained with the use of the EG\&G ORTEC $92 \mathrm{x}$ Spectrum Master program package. The standard U.S.G.S. rocks BCR-1, JB-2, JR-1, and Mag-I were analyzed simultaneously with samples to provide a check on the accuracy of the method. Two recounts were also performed to check the precision of the instrumental method.

Analysis for the geochemical data sets was performed by constructing two dimensional plots (Appendix A, graphs A-1 through A-16) of various elements in an attempt to establish groupings and/or linear trends between the different sets, as 
well as comparison with the other reported tephra compositions.

\section{COMPILATION OF BOREHOLE LOGS}

The most extensive subsurface data base in the LCRB is that of industry boreholes drilled and logged for foundation testing. The borehole records include locations at all of the major bridges, port facilities, and industrial centers. Many of the borehole logs record lithologies from depths of at least 30 meters below msl. Water well logs are also available for much of the river basin in areas not adequately explored by the industry borehole logs. Wherever possible the foundation test bore hole logs were used rather then existing water well logs to characterize the Holocene fill in areas adequately represented by industry drillhole records. This preference of using the industry drillhole records is because these logs generally have more detailed and reliable Iithologic descriptions and the locations are more accurate. The methods of analysis for the industrial drill core logs are as follows: initially over 1000 drill core and 200 water well logs were obtained from the following sources; Oregon Department of Transportation (ODOT) region I and region II geology offices; Washington Department of Transportation (WASHDOT) region IV geology office; U.S. Geological Survey Water Resources Department, Oregon Division; Washington Department of Ecology; Northwest Oil and Gas Report; Fujitani 
and Hilts Inc., Portland office; U.S. Army Corps of Engineers, Portland division; L.R. Squires Inc., Lake Oswego, oregon; and Dames and Moore Inc. of Portland, Oregon. The drill core logs were then compiled by the author who analyzed the logs and compared the location, elevation, lithology of the sediments, stratigraphic sequences, and nature of the lithologic contacts. These sedimentary characteristics were then incorporated into data base files for the purpose of evaluating the Holocene sedimentary stratigraphy.

Data for the last 163 borehole records (MAP ID\# 1324 through MAP ID\# 1487, Appendix B) were compiled by Ian Maden (1990), who generously contributed this information on the behalf of the Oregon Department of Geology and Mineral Industries (DOGAMI).

Appendix $B$ is a table of numeric information compiled from both industrial borehole and water well records. The table is designed to convey both geographical position (in UTM coordinates) and geologic information (depth to Holocene contact). A complete explanation of the data base appears in Appendix B. A brief sample appears in Table IV. The existing data distribution did not permit a regularly spaced network of sample sites or include a statistically valid grid for comparisons of sediment distribution. However, the distribution of 1487 core logs distributed throughout the 
Location

Weyerhauser

Longview

Mt Coffin

site
MaP ID\# UTM EAST UTM NORTH Surface Ho
EleV ft Dep
Hole Hole QalBasal QalBasal Gis
Depth Ft Base Ft ContactFt ContactM Code

$\begin{array}{rrrr}1 & 500775 & 5108222 & -16 \\ 2 & 500801 & 5108183 & -18 \\ 3 & 500828 & 5108152 & -20.5 \\ 4 & 500868 & 5108110 & -12.5 \\ 5 & 500789 & 5108201 & -19 \\ 6 & 500838 & 5108218 & 20\end{array}$

$\begin{array}{rr}6.5 & -22.5 \\ 38 & -56 \\ 35.5 & -56 \\ 16.5 & -29 \\ 34 & -53 \\ 36.5 & -16.5\end{array}$

Basal Isopach Isopach Ash Feet Meters Code Min Max

Location: General description of the borehole location.

Map ID\#: Point Number that represents the unique designation for each borehole log.

UTM EAST: Universal Transverse Mercator grid position in zone 10. All values are in meters.

UTM NORTH: Universal Transverse Mercator grid position north of the equator. All values are in meters.

Surface Elev Ft: Surface Elevation in feet from sea level (USC\&GS datum) indicated on the borehole records.

Hole Depth Ft: Hole depth in feet.

Hole Base Ft: Hole Base Elevation in Feet; Base elevation in feet of the borehole.

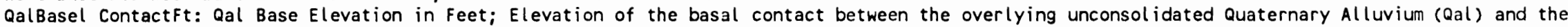
underlying Formation.

QalBasal ContactM: Qal Base Elevation in meters; Same as above column only in meters.

Basal Lithol: Basal Lithology; Lithology of the underlying strata below the unconsol idated alluvium.

Isopach Feet: I sopach in feet; Thickness of Qal and Qff in feet.

Isopach Meters: Isopach in meters; Thickness of Qal and off in meters.

Ash Code: Binary code used to indicate the presence of the Mazama Ash occurrence. $1=y e s ; 0=$ no.

SPT MinMax: Standard Penetration test values. Reported as minimum and maximum values for the unconsolidated alluvial fill. 
study area, is sufficient to qualitatively analyze trends of sediment distribution, such as general grain size partitioning within the valley fill.

The two dimensional cross sections of the river valley fill were constructed by using a computer graphing program (Golden Software Grapher). The linear distributions of the bore hole sites, surface elevations, and underlying Iithologic contact elevations were plotted. Then the graphs were imported into a computer drafting program (Autocad) for Iithologic pattern designation and final preparation of the cross sections.

A Geographic Information System (PC Arc Info) was used to construct plan view maps of the entire study area. The maps for the lower Willamette and lower Columbia River regions were created by digitizing the 32 U.S.G.S. 7.5 minute topographic sheets that cover the Columbia and lower willamette River floodplains. The margins of the Columbia and Willamette river floodplains served as the boundary for the 0 isopach contour Iine. In the areas upriver from Longview, washington the USGS 7.5 minute topographic 40' contour line was delineated as the edge of the floodplain. This elevation also closely corresponds to areas mapped as "Qal" by previous investigators. In only one case was an area above the 40 foot contour line included within the floodplain boundary. This occurrence is on Sauvie Island and is discussed later in the text. The 40 foot contour Iine was used because it represents 
a consistent reference line that appeared on all of the U.S.G.S. topographic maps. The maximum elevation of floods in historic time recorded by the U.S. Army Corps of Engineers reached elevations of only 32.8 feet (1948) and slightly greater during the 1894 flood event in the Portland basin. Below Longview in the estuary region and adjacent tributaries the floodplain margin was digitized along the $25^{\prime}$ supplemental contour line. The 0 isopach surface is defined as the upper surface of the modern flood plain. This floodplain surface elevation decreases in the downstream direction and also from the margins of the floodplain towards the modern river position. Note, that while the isopach surface undulates with floodplain topography, it represents a consistent time line. Therefore, the isopach lines do not necessarily represent equal elevation surfaces, but do represent equal sediment depth surfaces.

The isopach maps for the sedimentary fill volume of the LCRB were also constructed using the GIS system. Initially the post catastrophic flood sediment thicknesses in meters (column 13 of Appendix B) were plotted on base maps for the entire study area. Then contour lines were drawn by hand at 10 meter intervals. Finally the contour lines were digitized into a separate coverage using the GIS system.

The volume of fill calculations were derived by partitioning the LCRB into 12 depth intervals $(0-10,10-20$, $20-30,30-40,40-50,50-60,60-70,70-80,80-90,90-100,100-$ 
110, and 110-120 meters) from the isopach map. The volume of each depth interval was calculated by taking the product of area (in $\mathrm{M}^{2}$ ) for each polygon and the average thickness for the respective isopach interval. Note, even though there is no 120 meter isopach contour, the depth calculation used a $115 \mathrm{~m}$ value as the average amount of fill for the 110-120 $\mathrm{m}$ polygon. Finally, all of the polygon areas for the isopach intervals were summed to reach the final value for each depth interval.

ANALYSIS OF BOREHOLE DATA USED FOR THE CROSS-SECTIONS

Analysis of the industrial bore hole logs used in the cross-sections was performed by partitioning the Holocene sediments into general groupings based on the most abundant grain size fractions distributed within the sedimentary horizons as indicated by the core logs. All sediments that were delineated as silt, clay, or mud, on the logs are termed silt and clay on the cross-sections. The sand size fractions were partitioned into fine, medium, and coarse sands when adequate detail was given on the core log. But, for many of the water wells and some of the industry holes the logs did not partition the sand sized sediments into fine, medium, and coarse fractions and therefore the description of sand is used for all three fractions. Mixtures of sand and silt are also included and termed sandy silt, silty sand, stratified sand and silt, etc., depending on the lithological description in 
the corresponding drillhole log. The term gravel is used for all sediments in the gravel size range.

The depth of the Holocene contact with the underlying sedimentary strata was delineated from borehole logs as the boundary horizon in which the drillhole penetrated sediments described as cobbles, boulders, or dense gravel. This partition is based on the assumption that the last of the catastrophic Pleistocene floods were of very high energy. The floods were apparently capable of transporting much larger grain size sediments then is observed in the modern river environment, particularly as the head of tide has since progressed up the valley with the ensuing marine transgression. However, it is possible that some of these coarse grained sediments could have been transported and deposited by the river system since the Missoula floods. Conversely, some of the deep sands found in the drillholes that are designated as part of the Holocene fluvial system could represent lag deposits (especially in the Portland basin area) left by the winnowing flood events.

In short, the basal contact elevations of the Holocene fill are taken here to be at major lithologic transitions between the overlying unconsolidated sand and/or silts, and the underlying unconsolidated coarse grained gravel or cobble fill, or consolidated units such as cemented sedimentary units (Troutdale and Astoria Formations) or bedrock units (Boring 
Basalts, Columbia River Basalt Group, Gobel volcanics, and the Skamania volcanics).

\section{ANALYSIS OF THE SEDIMENT PARTITION DATA}

Borehole records 1 through 1324 (Appendix B) contain some form of lithologic description based on grain size for the late Quaternary alluvial sediments deposited in the LCRB. The borehole records collected from engineering firms, oregon Department of Transportation (ODOT), WASHDOT, etc., alI used grain size analysis to delineate the respective lithologic characteristics. The grain size partitioning increments are based on the Unified Soil Classification (USC) system. The USC system defines the grain size boundary between sand and silt at $0.074 \mathrm{~mm}$. The water well lithologies did not use the USC system for lithologic distribution. These lithologies were recorded by the driller, who is generally experienced at giving rough estimates of sediment lithology based on observed grain size.

Appendix D displays the sediment grainsize partition data used for lithologic partitioning. The lithologies were partitioned into four primary categories discussed below. The 54 borehole records used in Appendix D were chosen primarily on their total depth. I generally chose the borehole records that reached the lowest hole base elevation to ensure that the lowest elevation horizons would be represented. To ensure a wide spread distribution, boreholes from throughout the basin 
were selected even if they did not penetrate to lower elevations then other boreholes. I preferred to use boreholes from engineering projects as opposed to water wells drillers logs because the engineered holes involved laboratory testing and better quality lithologic descriptions. But, water well logs were used in areas where the engineered holes were not available, or where the water wells penetrated to lower elevations and therefore were used to add additional control for greater subsurface depths.

The four lithologic designations were delineated as sand, silty sand, sandy silt, and silt. These four lithologic components were used because nearly all of the borehole records described the sediments using these lithologic terms, and rarely were coarser and finer grained sediments encountered according to the core logs. When grain sizes larger than sand were encountered, such as gravel, sandy gravel, sand and gravel, and gravelly sand, they were included with the sand designation for the grain size partitioning data. As mentioned earlier, often the Holocene contact with the underlying catastrophic flood deposits was delineated at the boundary between medium and very coarse sediments. The coarse grain sizes classified here refer to those sediments which had substantial amounts of finer unconsolidated sediments below and were not designated as pre-Holocene deposits. Similarly, when grain sizes smaller than silt, such as clay, mud, peat, clayey silt, and silty clay, were 
encountered they were included with the silt grain size category for the sediment partitioning designations. The silty sand designation includes lithologies described as silty sand, sandy loam, and, sand and gravel and silt. The sandy silt designation includes lithologies that implied a greater component of silt than sand, such as sandy silt, silt loam, and, sand and silt and clay (or mud). Occasionally, when the lithologic description used sand and silt, or loam, as the lithologic description, these intervals were split in half with $50 \%$ of the respective interval assigned to the sand category and the other $50 \%$ assigned to the silt category.

The isopach depth listed in Appendix D for the borehole records occasionally deviates from the isopach depth listed in Appendix B. This occurs because the isopach used in Appendix B occasionally includes material (such as dredge spoils) used for fill. For the isopach used in Appendix D, any fill material indicated on the borehole record was subtracted out because I wanted to account for only grain size distribution that occurred from natural depositional processes.

Appendix D represents a table of numerical values derived from the borehole logs. This table was constructed for the purpose of displaying the measured values for sand, silty sand, sandy silt, and silt, and the subsequent percentages of each grain size lithology for each of the borehole record. Three types of total values are listed. The first value labeled "borehole percent" is the average percentage for each 
grain size lithology for all of the boreholes. This value gives equal representation to each borehole regardless of its penetrated depth. The second total value listed labeled "isopach percent" is the average percentage for each Iithology based on total penetrated depth for the boreholes. This value gives a proportionately greater influence to those boreholes that penetrated deeper into the basin fill, because the total sum of a particular grainsize amount was divided by the sum of the total penetrated isopach depth. Therefore each foot of penetrated depth carries equal value, (i.e. a 300 foot penetration hole carries 3 times as much value as a 100 foot penetrated depth hole. This value was used as the lithologic percentage of "total infilled sediment" in the LCRB stated later in the thesis. Below each of the elevation interval columns is the total percentage of grain size distribution for each of the elevation intervals. The subsurface elevation intervals are listed in feet (rounded to the nearest 0.5 feet) but correspond to 10 meter intervals (i.e. the 0 to 33 foot subsurface elevation interval approximately equals the 0 to 10 meter interval). The values were used for comparison of grain size distribution with subsurface elevation.

The Map ID\# numbers in column 1 correspond to the Map ID\# of Appendix B. Generally, the borehole records are arranged in order of their upstream progression. 
RESULTS

THE MAZAMA ASH LAYER

A distinctive layer of volcanic ash has been encountered in numerous (197) (Appendix C) deep test borings in the flood plains of the Willamette River from Swan Island to the mouth, and the Columbia River from Troutdale to Warrenton. Since 1959, when the layer was first recognized and sampled in borings from the Rivergate area of North Portland, mapping of its occurrence has been maintained primarily by Ken Robbins. Microscopic analysis showed the ash is mainly glass shards with indices of refraction in the range of Mazama ash. Additional efforts for identification were undertaken in 1975 when samples were submitted to Dr. Beeson (Portland State Universityl for trace element studies and to $\mathrm{Dr}$. Kittleman (University of oregon) for mineralogical analysis. The trace element studies clearly showed the ash to be Mazama; however, the mineralogical studies could identify only those samples that were already known to be Mazama (i.e. samples of untransported ash).

The ash layer is waterlain and is a good marker for the flood plain elevation in the Portland area at the time of the Mazama eruption. A complete database for the Mazama ash layer occurrences appears in Appendix C. The general basinwide range 
is from -41 to -92 feet $\mathrm{msl}$. The average elevation of the base of the ash layer for the Portland basin occurrences (includes sites down river to Trojan) is -56.8 feet $(-17.3$ meters) msl. The average elevation in the Longview basin (includes sites down river to the Beaver Army terminal near Locoda Oregon) is -62.9 feet $(-19.2$ meters). For the sites down river from Skamokowa, Washington, the average elevation is -59.3 feet (18.1 meters). No occurrences were recorded between Skamokowa, Washington and the Beaver Army terminal area. The layer thickness is quite variable from thin layers less then $1 / 2$ inch to a maximum of 35.5 feet (Map ID\# 940, in the main Willamette River channel near Linnton, Oregon). The average thickness is about 3.4 feet ( 1.0 meters). For the isopach calculations, layers designated as TL (thin layer) or NG (not given) were assigned an isopach of 0.1 feet. Also, layers that were assigned a less than (<) value assumed the maximum thickness indicated.

The May 18, 1980 eruption of Mount St. Helens provides an excellent example of rapid tephra dispersal in the Columbia River. Hubbel and others (1983), estimated that $27.5 \times 10^{6} \mathrm{~m}^{3}$ of sediment was contributed in the first 24 hours after the eruption. This pulse of sediment input reduced the $12.2 \mathrm{~m}$ deep navigation channel to $4.3 \mathrm{~m}$ at the mouth of the Cowlitz River. 
In most instances of the Mazama ash occurrence, there are abrupt, distinct contact at both the upper and lower surfaces of the ash layer. In some instances there is a thin interbedding of fine sand, silt and/or clay at the contacts, usually the upper contact (K.C. Robbins, Personal Communication, 1992). The ash layer itself is quite homogenous and free from contamination by other flood plain materials.

The ash occurs as a very firm layer when thicknesses of six inches or more are encountered. Sample blow counts are commonly as much as three times those for the flood plain deposits occurring above and below the ash layer. The ash layer is characteristically light gray to pale purplish gray when wet and dries to a very light gray to chalky white. Laboratory tests indicate the following physical properties: grain Size: generally 95 to $100 \%$ passes \# 200 sieve $(0.074 \mathrm{~mm})$; shear strength: non-cohesive with average phi=31 (K.C. Robbins, unpublished data, 1992).

Considering the small (silt) size of the ash particles, the environments of sediment deposition would indicate quiet low energy settings of channel sloughs and floodplains. Some of the large isopach deposits probably represent channel deposits such as point bars (M.H. Beeson, personal communication, 1994).

The Mazama ash deposits in the lower Willamette River basin were derived from ash fluvially transported down the Willamette River, as opposed to backflooding from the Columbia 
River. The U.S. Department of Agriculture soil Surveys from Lane County, Linn County, and Clackamas County, all state that pyroclastic material occurs in the sifton soils of the winkle surface in the Willamette Valley. The Winkle surface is an early to mid Holocene $(10,850 \pm 240$ yr to $5,280 \pm 270$ yr) alluvial surface deposited in the floodplain of the Willamette River (Reckendorf, 1992). Generally, the ash occurs as fine grained material in the intersticial spaces of coarser grained deposits of gravel (Reckendorf, 1992). The extensive deposits of ash in the upper portions of the willamette valley indicate that the deposits found in the lower willamette River basin were derived from the willamette River.

\section{GEOCHEMICAL ANALYSIS OF THE TARGET ASH LAYER}

The target ash samples that I analyzed were irradiated for INAA in the Oregon state University TRIGA MARK II Reactor. Gamma Ray spectra were obtained at Portland State University. Thirty tephra samples were previously prepared and analyzed by various investigators.

The geochemical data for the sample sets (Appendix A, Tables A-1 and Table A-2) used for tephra source analysis were collected by four different analysts from five separate experiments. Sample set NG-1 through NG-9 (Appendix A, Table A-2) are all ash samples from drill cores located along the southern margin of the Columbia River estuary. Sample sites (Appendix A, Table A-3) range from Warrenton, Oregon, west of 
Astoria to the Fernhill/Burnside road area about 8 miles east of Astoria. The sampled horizons range from -48.5 to $-69.4 \mathrm{ft}$ msl. The gamma ray spectra for these nine samples were obtained by the author. This set of nine samples is collectively referred to as "Astoria ash" on the odd numbered graphs presented in Appendix A.

Sample sets L-1 through L-7 (Longview, Washington) and P1 through P-13, P-16 and P-16-1.5, (Portland area) (Table A-3) are all samples of suspect ash (except for P-16-1.5 which is sediment from 1.5 ft beneath the ash layer basal contact in sample P-16). These samples are from drill cores located in the Longview, Washington and Portland, Oregon areas. For the Portland area samples both Willamette and Columbia River sites are represented. The element concentration numbers for these samples were obtained by Dr. Marvin H. Beeson, at Portland State University.

Sample sets StH-JB through StH-UGG are all Mt. St. Helens tephra. These samples are from tephra unit set $S$ and set $J$ (Tables A-1 and Table A-3) and represent multiple layers within each set. The samples were submitted by Dr. Paul E. Hammond of Portland State University to Dr. Marvin H. Beeson and were part of the same irradiation batch as the Longview and Portland sets. Sample set MAZ-1 through MAZ-3 (Tables A-1 and A-3) are all known Mazama ash samples from locations in central Oregon (Beeson, unpublished data). Samples MAZ-4 (CFPAVG-1) and MAZ-5 (CFP-154) are also known Mazama tephra 
samples. The geochemical data for these two samples is from Bacon and Druitt (1988). It should be noted the Bacon and Druitt (1988) did not report geochemical concentrations for Cobalt. The Phelps Creek sample represents tephra from Phelps Creek, near Trinity, Washington. This tephra has been attributed to one of the two eruptions of Glacier Peak 11,200 ka (Randle, Goles, and Kittleman, 1971). The geochemical data point from this sample is labeled "Glacier Peak tephra" in figures A-1 through A-16 of Appendix A.

All the graphs in Appendix A (graphs A-1 through A-16) are arranged in pairs. Odd numbered plots represent two elements plotted against each other for the Longview and Astoria area ash samples. The even numbered plots are for the suspect ash occurrence from the Portland area (both willamette and Columbia Rivers) tephra samples. This style of plotting was used for two reasons: first, to prevent the graphed points from appearing too cluttered; second, to delineate any differences between the Portland basin samples and the samples from below the Cowlitz and Lewis Rivers because these two tributaries have delivered large amounts of reworked Mount st. Helens tephra to the lower Columbia River basin.

\section{LITHOLOGIC DISTRIBUTION}

During Holocene time the lower Columbia basin sedimentation has been influenced by marine transgression 
along with infilling of terrigenous and volcanic sediments. Sea level rise has the same general sedimentologic effect as damming a river. The river responds by aggrading its bed in an upstream direction. Alluvial sands were found at least 90-100 meters depth in Cathlamet channel (Abby, 1989) providing direct evidence that the lower Columbia River has accumulated substantial volumes of sediment due to the effect of sea level rise.

Generally the Holocene sediments for the LCRB are dominantly fine sands. Fine sands are apparent in all of the borehole records (Appendix B) extending from Cape Disappointment, Washington and Warrenton, Oregon, up river to the Sandy River near the eastern extent of the study area, about 120 miles in river distance. While lenses and layers of both coarser sands and gravels, along with finer silts and clays, occur locally, fine sands are shown to be distributed throughout the entire lower Columbia River basin.

The results of the data analysis are plotted in a series of two dimensional cross sections that display the vertical and lateral lithologic distribution for the Holocene sedimentary deposits. The cross section locations are generally at bridge sites and developed port industrial areas where the data density is sufficient for both vertical and lateral characterization of the sedimentary fill. The basal contact for the Holocene fill is incorporated into the cross sections only in areas where it can be accurately determined. 
In the estuary region, The cross-sections for the Astoria bridge shows that fine sands occur from the base of the Holocene deposits at subsurface elevations greater than -275 feet ( -84 meters) msl, up to the modern river deposits. I have estimated the basal contact for the unconsolidated late Pleistocene/Holocene sedimentary deposits to occur at about 393 feet msl (-120 meters). This subsurface contact elevation is based on the occurrence of a seismic reflector present at about -430 feet (-130 meters) elevation about 10 miles downriver of the cross-section location. The seismic survey was located near the mouth of the Columbia river south of Peacock Spit. The survey was performed by Geo-Recon Inc. The seismic profile was observed by the author but unavailable for reproduction. The location of the Astoria bridge cross-section appears in Figure 11. By comparison, grain size decreases in the peripheral areas off the main channel axis of the Astoria bridge cross-section (Figure 12). The deposit sorting is also more variable towards the valley margins, as shown by the presence of stratified sands and silts, and sandy silt deposits. These subsurface results are consistent with the findings of the CREDDP study that showed modern fine sediment (silts and muds) to be distributed in the peripheral bays and off channel axis bars (Figure 4).

The Puget Island cross-section (Figure 13 and Figure 14) shows a better record of the isolated lithologic lenses of channel cut and fill structures. This cross-section probably 


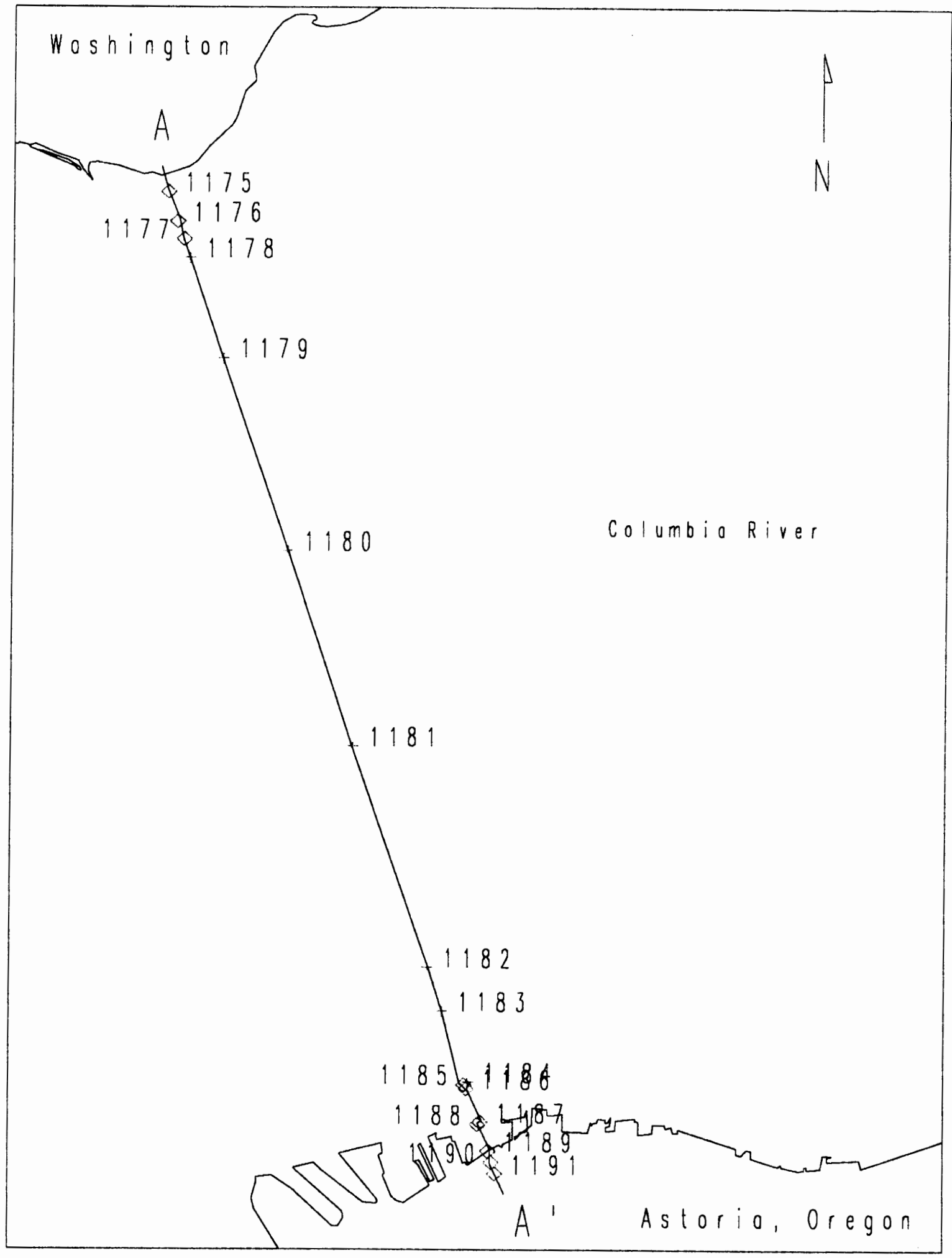

Figure 11. Locolion of Astorio bridge cross-section. 


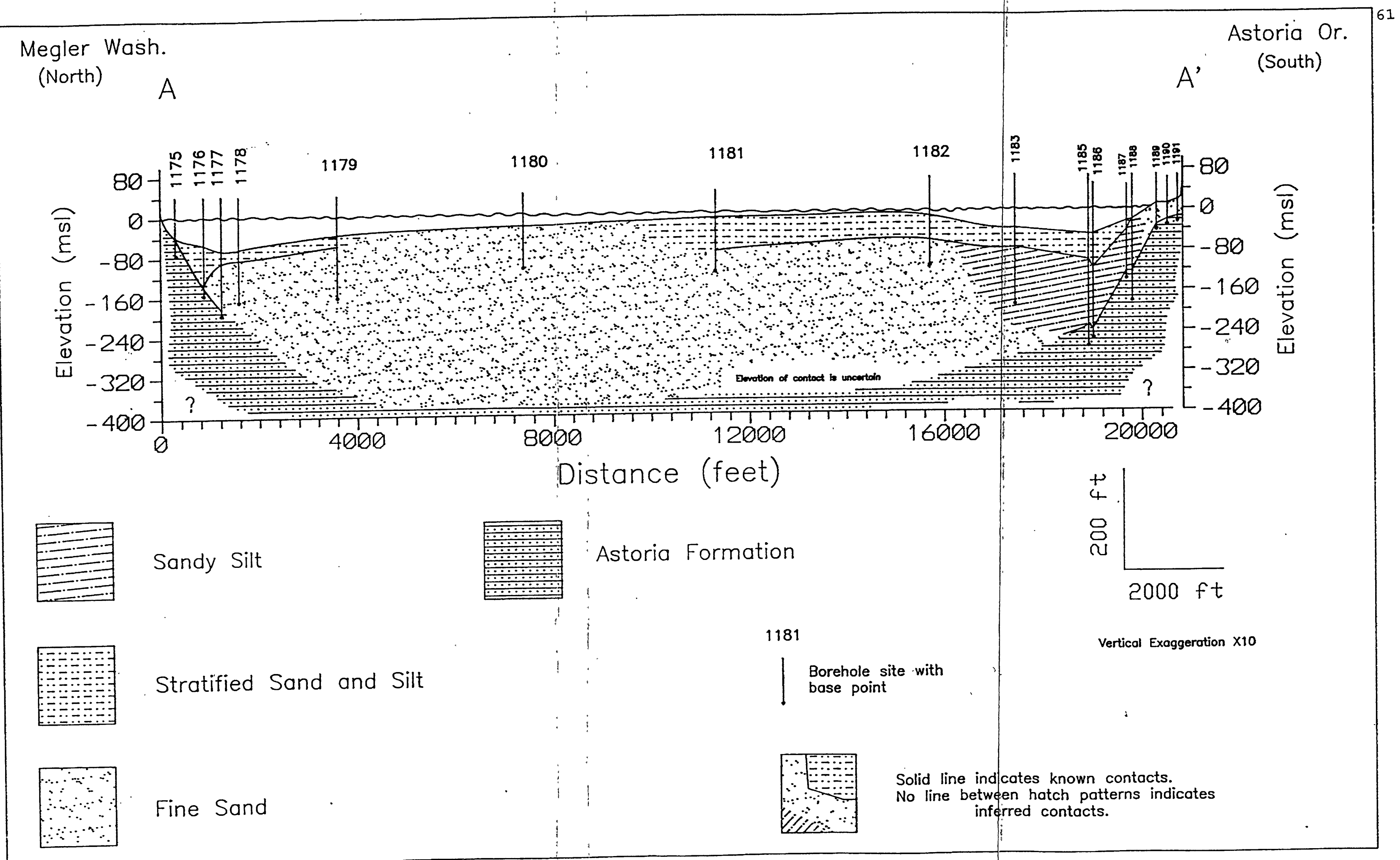

Eigure 12.: Astoria bridge cross-section. 


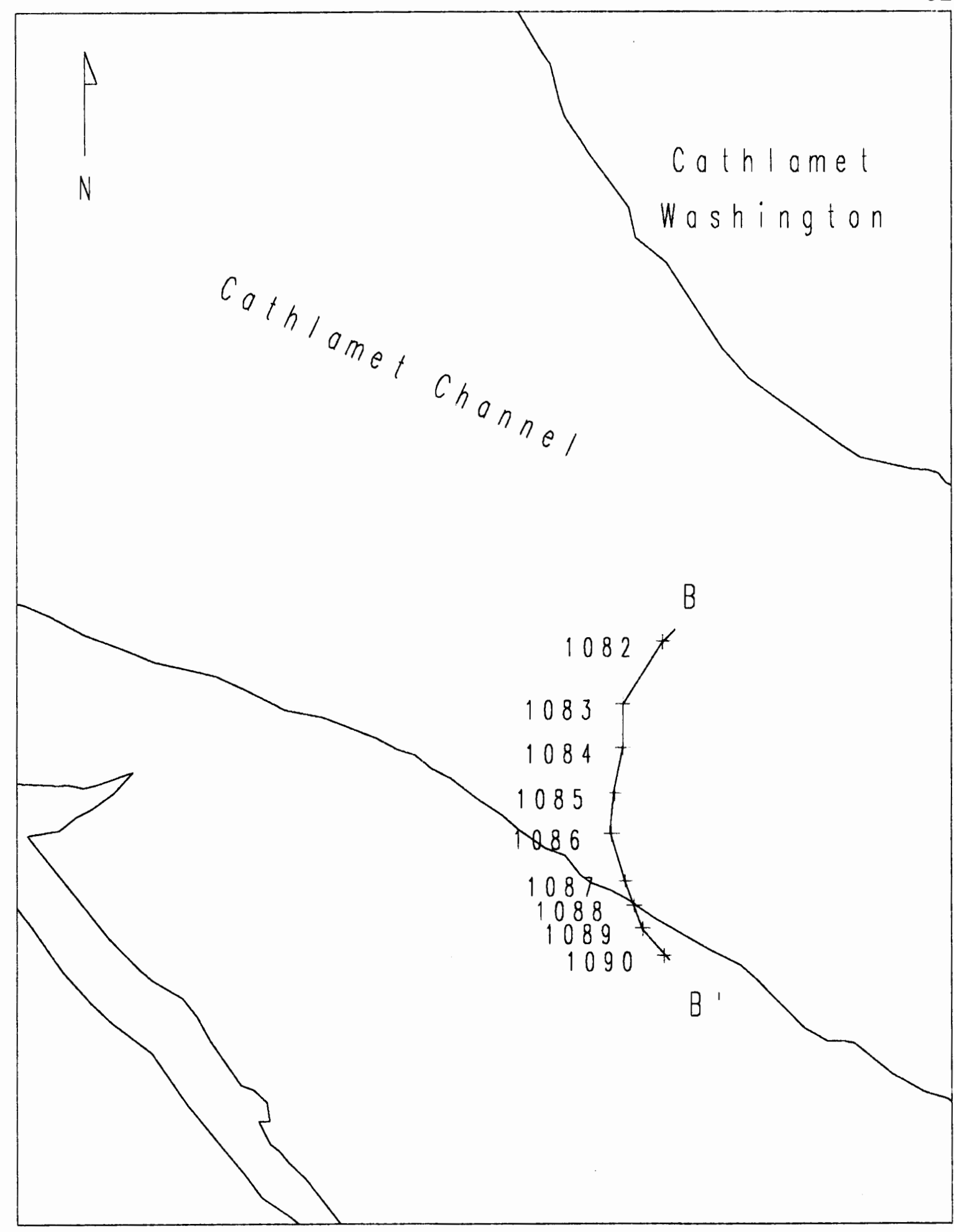

Eigure 13. Locotion of puget ls lond bridge cross-section. 


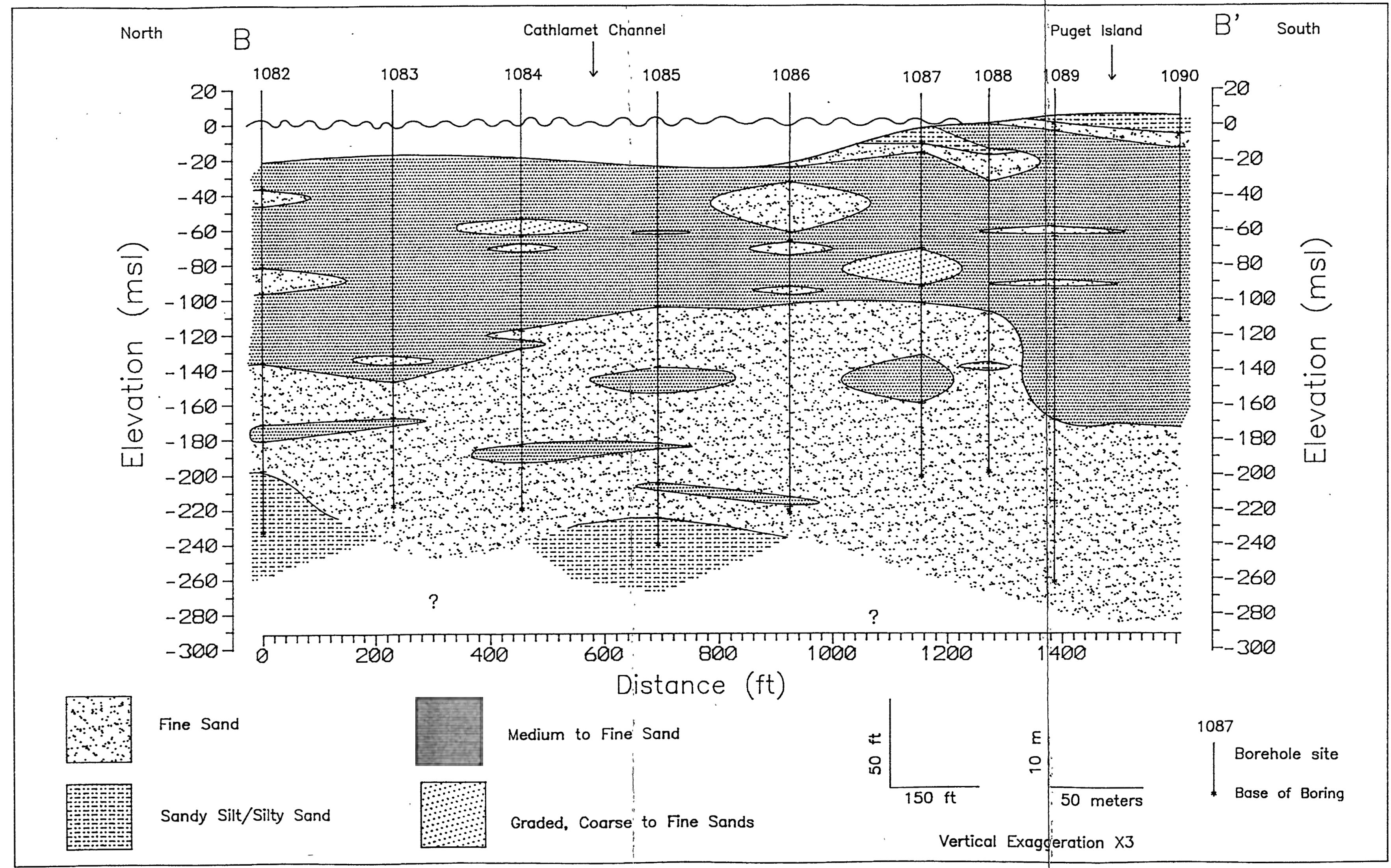

Eigure 14. Puget Island bridge cross-section. 
best exemplifies the distribution of the local lenses and cut and fill sedimentary structures because it used the shortest length compared to the other cross-sections. At depth none of the borings penetrated the pre-Holocene deposits. Generally, the dominant grain size distribution increases from fine sand to medium sands above the -120 feet $(-37$ meters $) \mathrm{ms}$ elevation. Both the sedimentary structures and coarsening upward trend most likely record a shift in the main channel axis (and subsequent higher energy regime) to the north side of the valley in this particular stretch of the river.

The cross-section (Figure 15 and Figure 16) from Oak Point, Washington to Locoda Oregon, near River mile 54, represents the deepest measured penetration for late Quaternary (post-catastrophic flood) sedimentary alluvium. The primary feature of note in this cross-section is the occurrence of the contact between the Holocene Columbia River alluvium and the underlying coarse-grained deposits. This contact is based on waterwell data from hole number 1154 and a geophysical contact near hole 1156. The contact at -286 feet msl (-87.2 meters) in hole 1154 was described as unconsolidated gravels by the water well driller and is interpreted by the author as catastrophic flood deposits. The deeper geophysical contact beneath the modern south channel axis is found near drillhole 1156. 


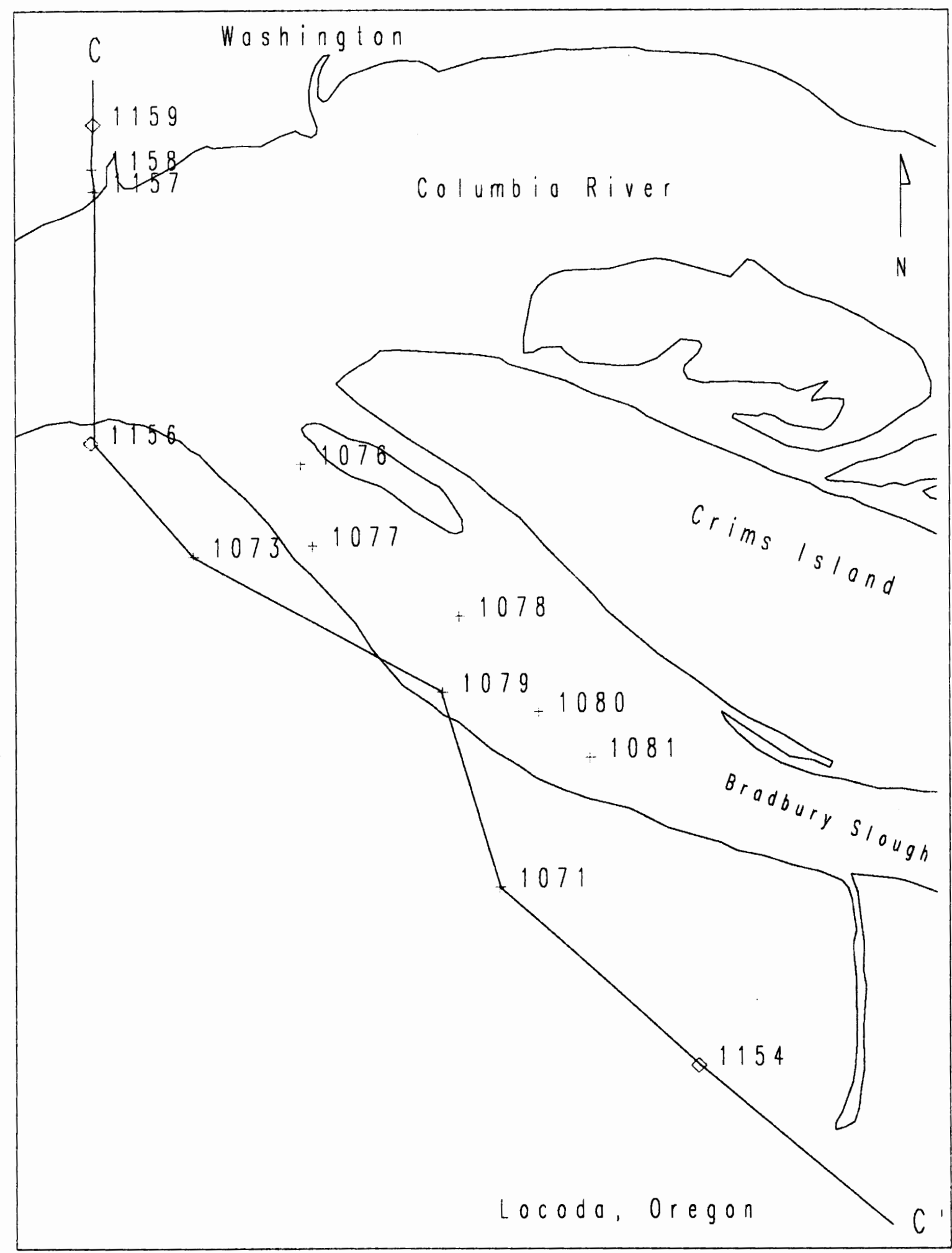

Eigure 15. Locotion of ook Point, Woshington to Locodo, oregon cross-section. 

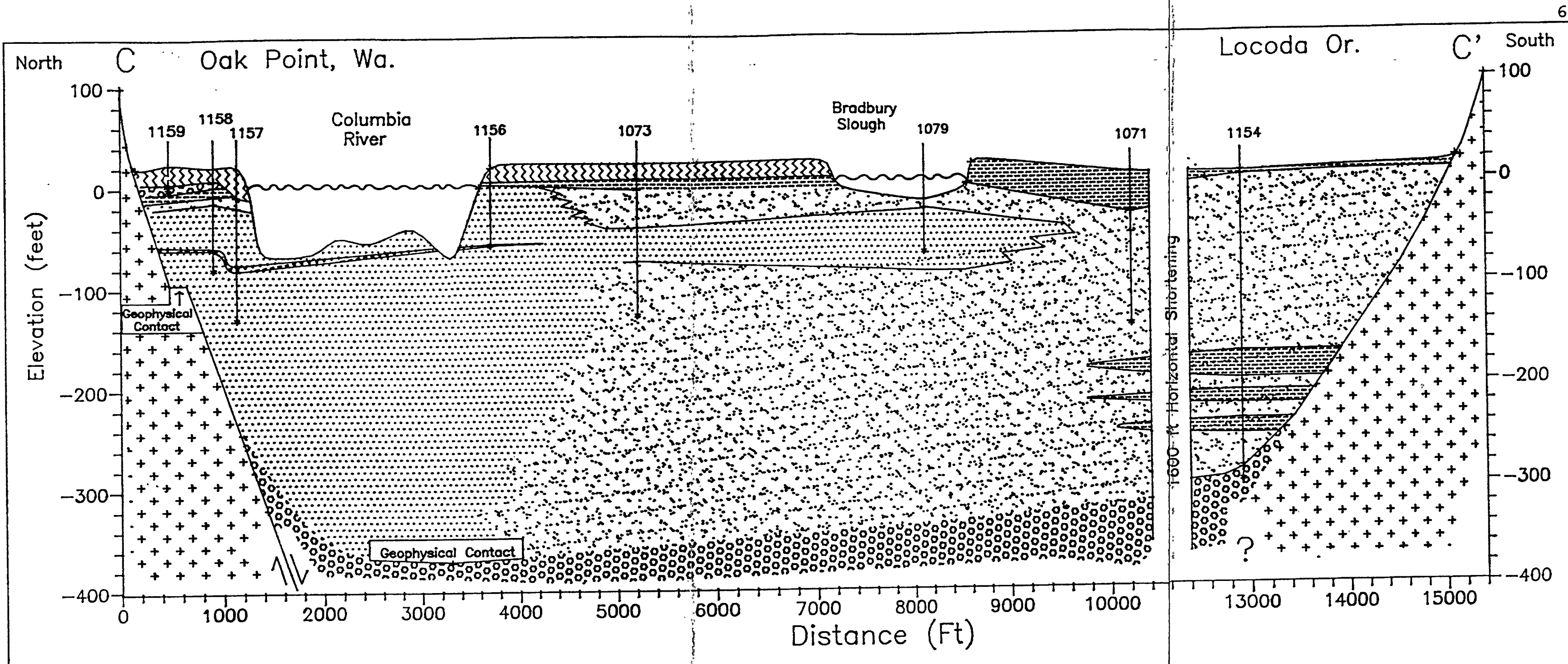

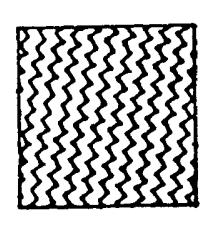
Artificial Fill
Mostly Dredge sands

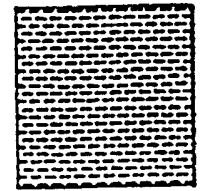
Cloy/Silt described as clay and/or silt.

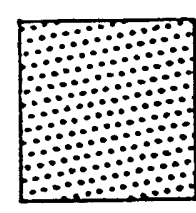

Graded Sands Unconsolidated fine, medium, and deposited by the Columbia River
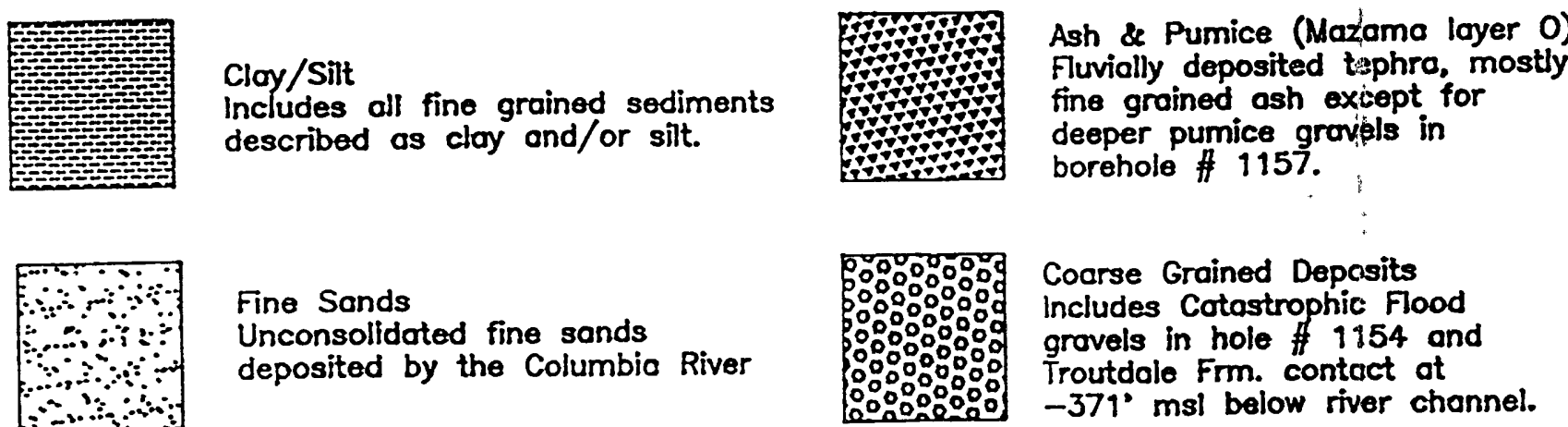
Fine Sonds
Unconsolidated fine sands
deposited by the Columbio River
Cocrse Grained Depasits Includes Cotastrophic Flood grovels in hole \# 1154 and Troutdale Frm. contact at
$-371^{\circ} \mathrm{msl}$ below river channel.
Vertical Exaggeration $\times 10$

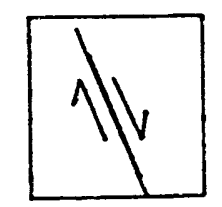

Foult; (Wells, 1981) Foult; (Wells,
Normol fault, probably inactive.
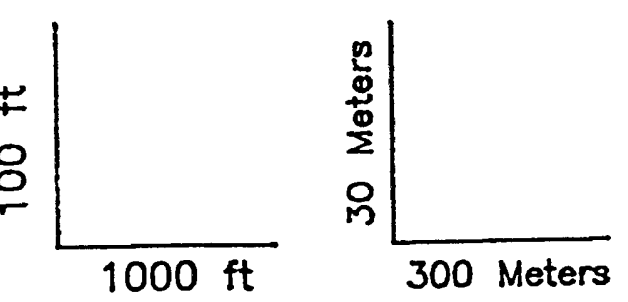

Wanapum Bosalt of the Frenchman Springs Member (Wells, 1981)

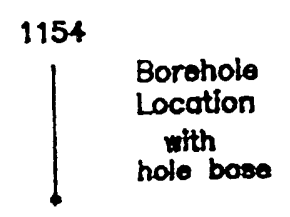


This geophysical contact, at -371 feet ( -113 meters), is based on a seismic reflector from an acoustic survey performed by Geo-Recon Inc. for a local utility company (data observed by the author but unavailable for reproduction). The contact is based on a one way travel time of .075 seconds (75 milliseconds) at a rate of $5000 \mathrm{ft} / \mathrm{s}$ as modeled in the survey for the subbottom overlying sedimentary alluvium. The presence of a sub-bottom reflector indicates the underlying strata has a significant density contrast with the overlying sediments. Also, nearby, the catastrophic flood deposits occur at -300 feet msl (-91.4 meters) in the Champlin well (Hole \#1292) approximately 5 miles ( 8 kilometers) downriver. Therefore, this reflector at -371 feet (113 meters), is most likely the contact with the underlying flood deposits or the Pleistocene Troutdale Formation.

The seismic survey on the north shore of the river near Oak Point, Washington at the mouth of Mill Creek (RM 54) indicated that hard rock was present at -97 feet msl (-30 meters). Rock was found 16 feet south of hole \# 1178, to 171 feet south of hole \# 1178 at a depth of 118 feet (36 meters). No rock was found further south of this point. The rock velocity was estimated to be approximately 10,000 feet/s. I have interpreted this rock stratum to be weathered basalt of the Columbia river Basalt Group. This interpretation is based on the observation that Wells (1981) mapped from surface outcrops at least two horizontal flows of the Wanapum Basalt 
in excess of 15 miles along the steep north slope of the Columbia River in this area. The basalt at depth could be Grande Ronde Basalt of the CRBG because these basalts normally occur relatively lower in the Miocene stratigraphic section.

A normal fault has been interpreted to form the steep northern slope of the river basin in this area. This interpretation is based on the occurrence of the CRBG at the surface and near subsurface (-97 feet, -30 meters) along the northern basin margin, yet the basalt is absent 3000 feet to the south and 275 feet (84 meters) lower under the southern river channel. Also, Wells (1981) mapped an ENE-WSW trending strike slip fault offset by a NW-SE trending normal fault only 2000 feet (610 meters) west of the cross-section axis. The fault is assumed to be inactive with the Holocene sediments in depositional contact. The Mazama ash horizon occurs in drillholes 1156, 1157, and 1158 .

The cross-section of the Longview Bridge (Figure 17 and Figure 18) shows the late Pleistocene and Holocene stratigraphy beneath the southern Longview basin. The crosssection extends from Rainier, Oregon in the south north to Industrial way' along the waterfront in the industrial section of the town of Longview. The profile shows lithified sands and gravels under a water well (hole \#227) interpreted by the author to be the Troutdale Formation. These deposits are assumed to extend under the Longview basin but none of the other drill holes penetrated this lithified strata. Drill 


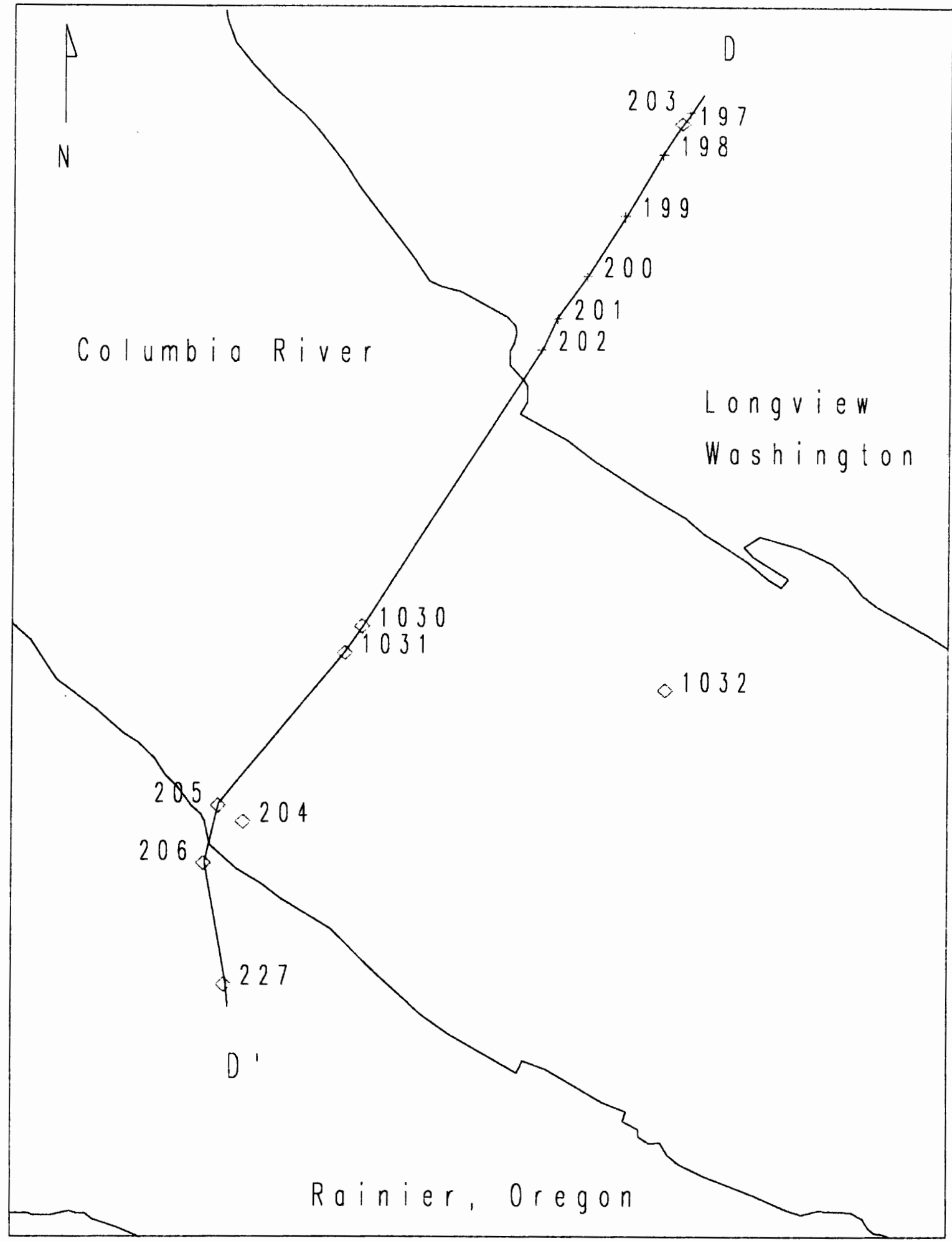

Figure 17. Locotion of Longriew bridge cross-section. 


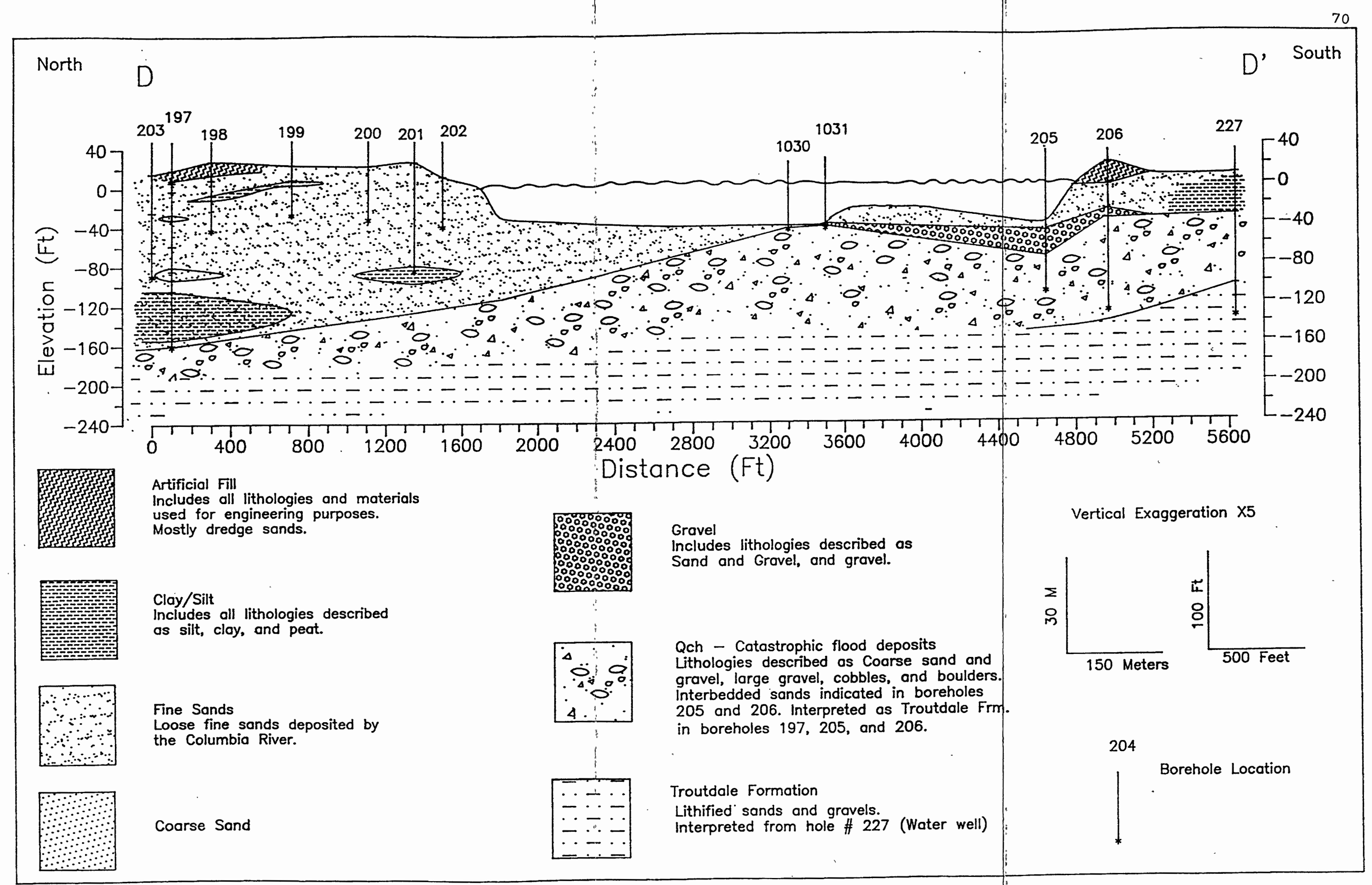

Eigure 18. Longview bridge cross-section. 
holes 206, 205, 1031, and 1030 all penetrated "cobbles, boulders, and coarse sands" at shallow levels (-15 to -42 feet) along the southern portion of the river and increased in depth to -160 feet at hole 197. This stratigraphic horizon was interpreted to be of catastrophic flood origin, based on the coarse grain size. The original borehole records indicated that this stratum was the Troutdale Formation in holes 205,206, and 197. Holes 205 and 206 indicated the presence of some thin layers of interbedded sands. Coarse gravels overlie the flood deposits along the modern southern channel while fine sands and lenses of fine grained sediments (silt, clay, and peat) occur throughout the rest of the cross section. Modern artificial fill deposits (dredge material ?) associated with the bridge construction occur at the surface.

The cross-section from Burlington, Oregon to Vancouver, Washington displays the lithologic distribution of sedimentary deposits and the position of the underlying medium-grained versus coarse-grained contact surface beneath Sauvie Island and the confluence region of the willamette and Columbia Rivers. Figure 19 shows the location for the cross-section that appears in Figure 20. Fine-grained deposits of silty sand occur beneath the flood plains of Sauvie Island and Vancouver, Washington. Medium-grained deposits of sands occur beneath the area of the confluence of the Willamette and Columbia Rivers and, beneath Multnomah Channel near the western margin of the cross-section. The Portland Hills fault defines the western 


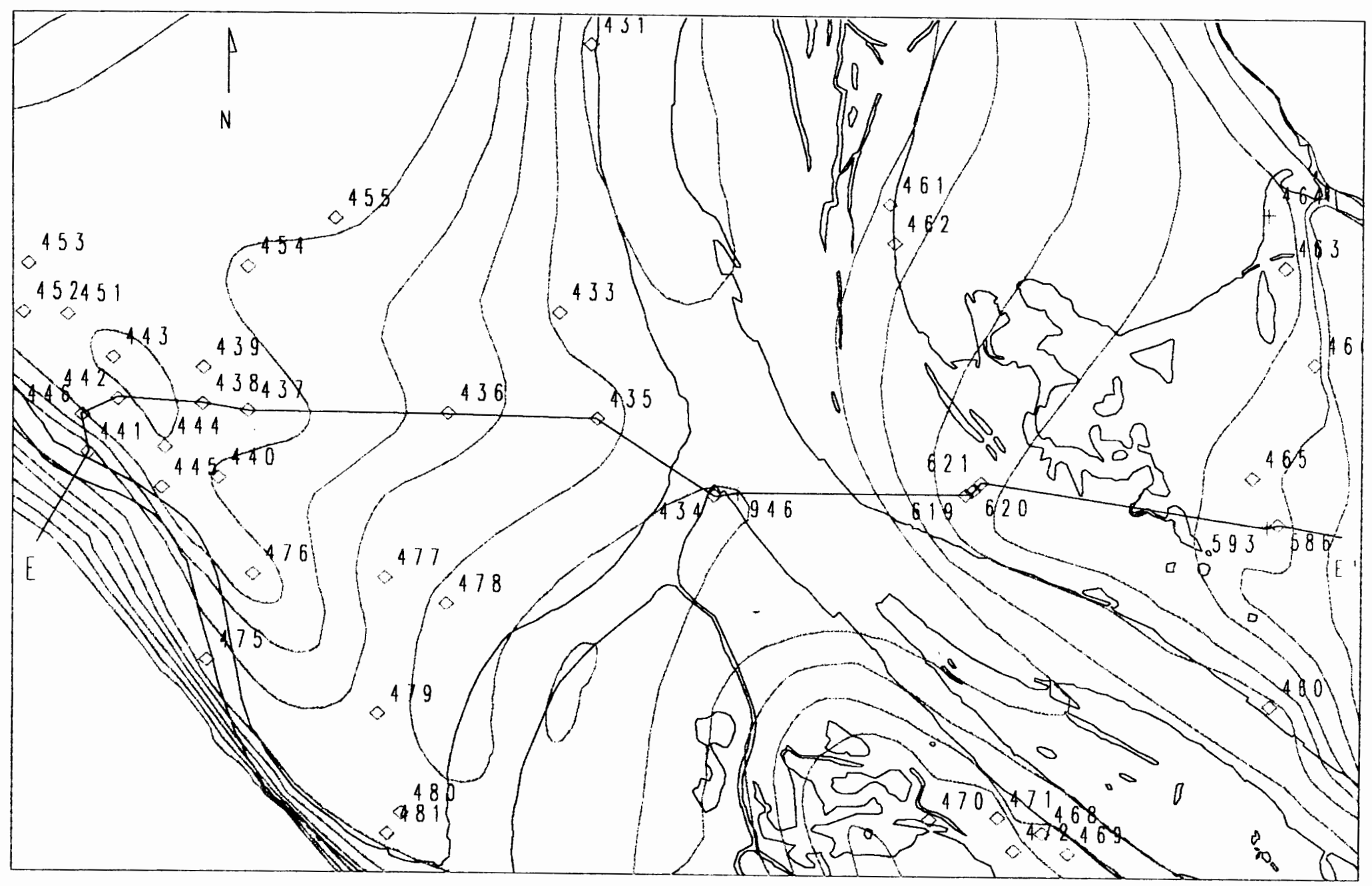

Figure 19. Burlington, Oregon to vancouver, Woshington cross-section locotion Contour lines represent 10 meter isopoch on Holocene and lole Pleistocene tine-groined deposits. 
boundary of the alluvial deposits just west of Multnomah Channel at the base of the Tualatin Mountains. The Portland Hills fault displays normal offset (Beeson and others, 1991). Beneath the medium and fine-grained deposits are extensive coarse-grained deposits of cobbles and gravels derived from the catastrophic floods that swept through the area during late Pleistocene time. Note that some of the fine-grained deposits overlying the coarse-grained deposits may have also been derived from the catastrophic floods, especially the areas above the 40' elevation on Sauvie Island. Further discussion of these upper Sauvie Island late Pleistocene deposits appears later in the text. The position of the contact surface between the fine-grained deposits of the late Pleistocene deposits versus the Holocene fine-grained alluvial deposits is uncertain. The Troutdale Formation underlies much of the eastern portion of the lithologic profile. The Troutdale Formation has been mapped at the surface at the eastern end of the cross-section and was also identified in borings 619, 620, and 621, beneath the floodplain of west Vancouver, Washington.

In the Portland area, the two major Freeway bridges (I-5 and I-205) provide the best locations for cross-sectional profiles because of the continuity of the data. Both profiles show Holocene deposits of fine sands and lesser amounts of local coarse sands, gravels, and silts deposited on the underlying Troutdale Formation. In both cross-sections the 
Troutdale Formation occurs at about -160 feet ( -49 meters) msl on the south side of the river and extends beyond the limits of the profiles underneath the modern floodplain. To the north of the modern channel axis the Troutdale conglomerates rise to near surface elevations.

At the I-5 bridge site (Figures 21 and Figure 22) the contact with the late Pleistocene catastrophic flood deposits is at -150 feet ( -46 meters) msl beneath Hayden Island. Fine sands are the dominant lithology of the Holocene fill throughout the entire cross-section. Coarse-grained sands and scattered gravels can be found just above the flood deposits beneath both the modern main channel and the oregon slough channel immediately south of Hayden Island. Fine-grained silts and clays with interbedded fine sands have been deposited throughout the Holocene under the former site of the city of Vanport on the southern floodplain.

The I-205 bridge cross-section location appears in Figure 23. The I-205 bridge cross-section (Figure 24) is quite similar to the I-5 bridge lithologic profile. Generally, the Troutdale Formation contact ranges from -80 feet (-24 meters) msl beneath the northern main channel to -180 feet ( -55 meters) msl beneath the southern floodplain, in the vicinity of the Portland Airport, where the conglomerate pinches out, exposing a window of the Sandy River Mudstone Formation. Overlying the Troutdale conglomerate is a deposit of fine 


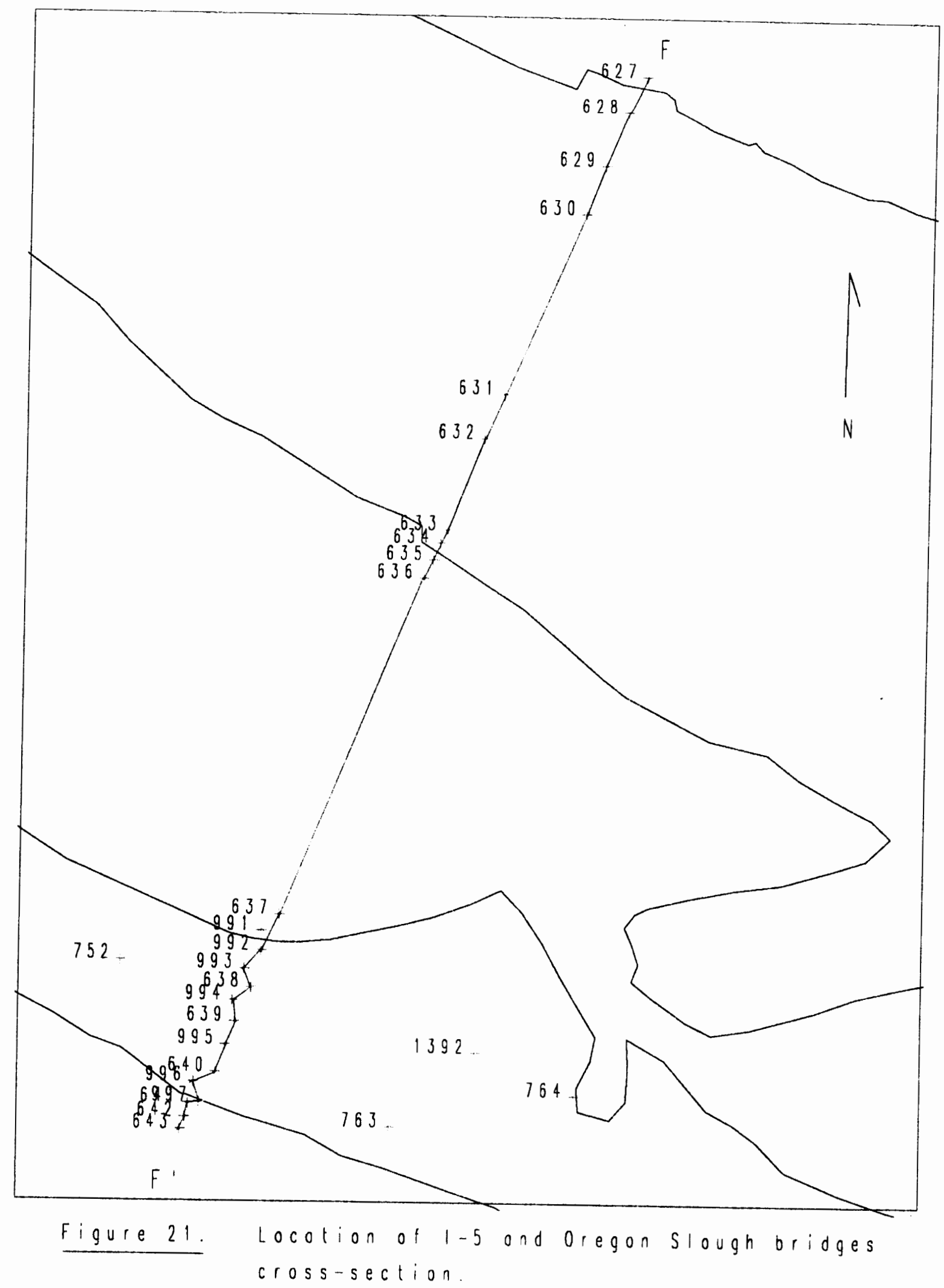




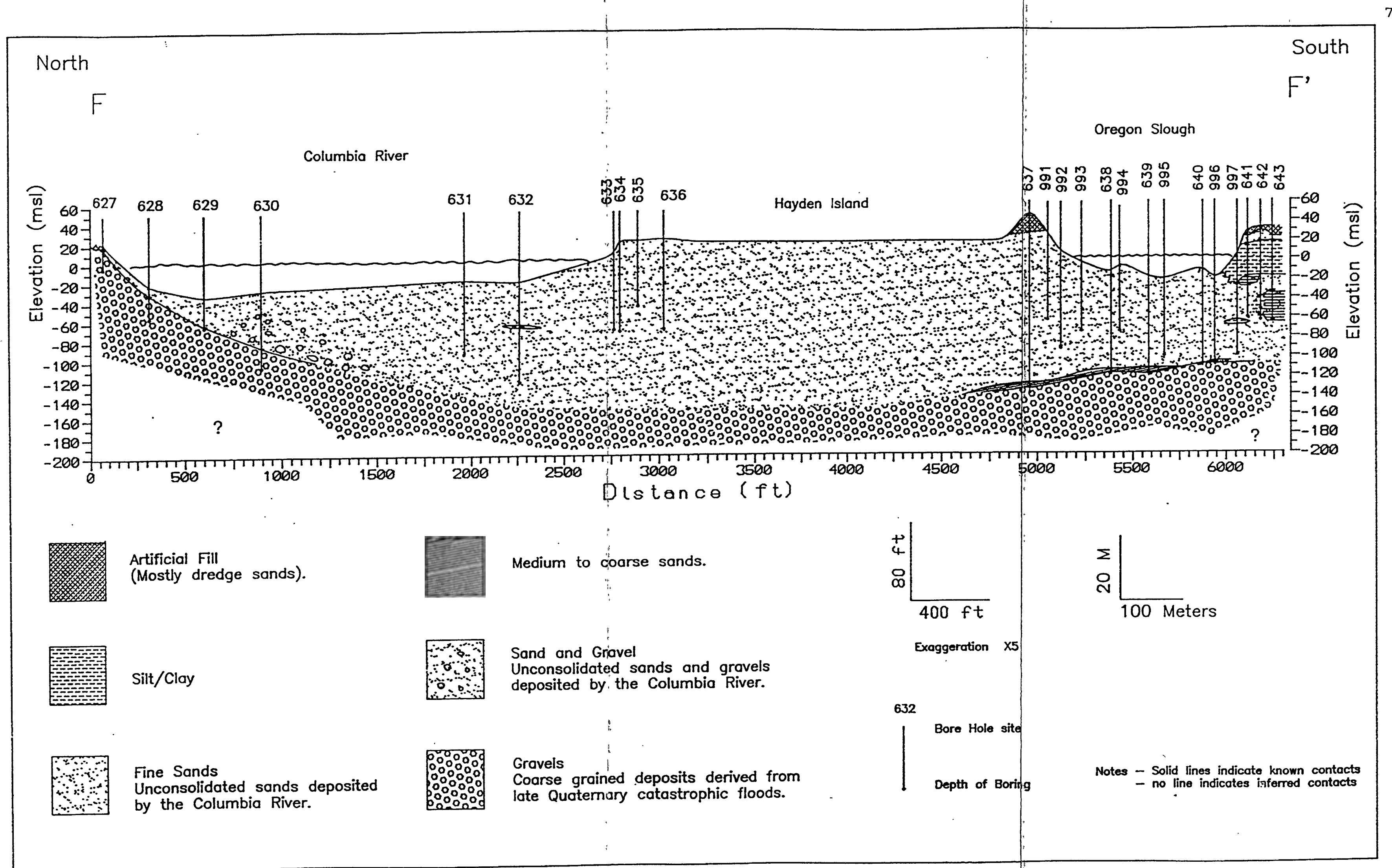

Figure 22. $\quad 1-5$ and Oregon Slough bridges cross-section. 


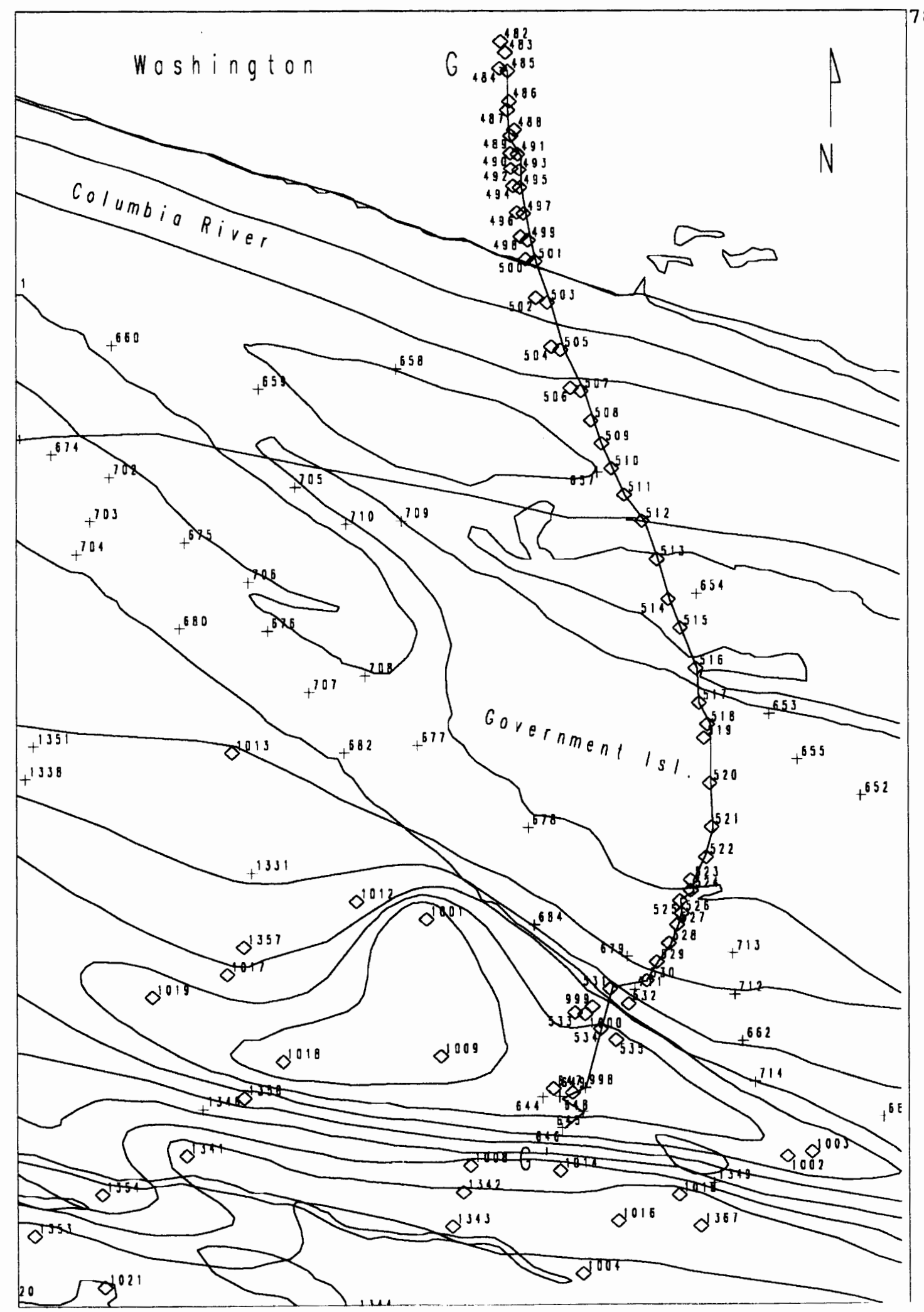

Figure 23. Locolion of l-205 bridge cross-section.

Contout lines represent 10 meler isopoch on Holocene olluviol deposils. 


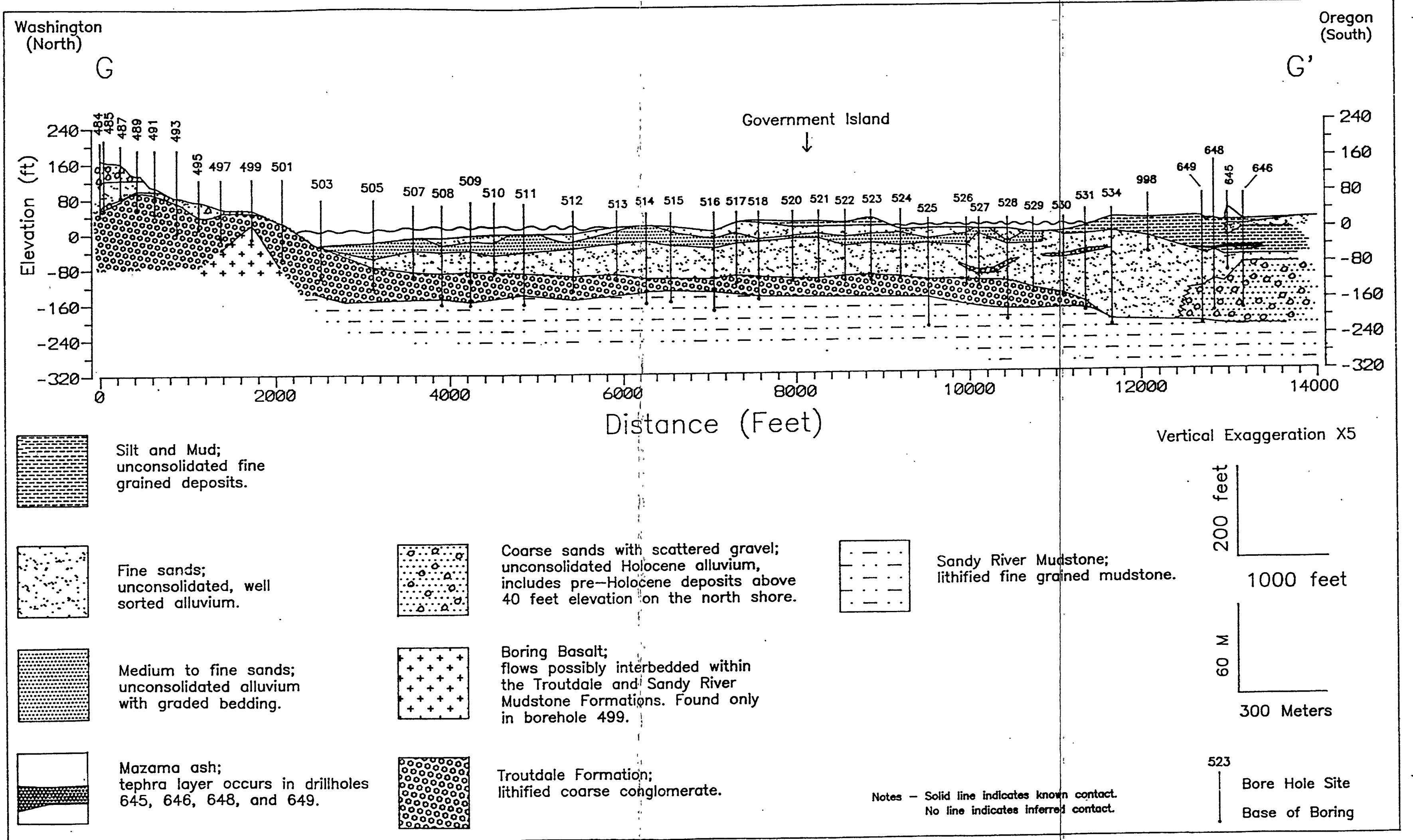

Figure 24. 1-205 bridge cross-section. 
sands the extends across the entire cross section. A 500 foot long gravel lens up to 10 feet in thickness is deposited within the fine sands beneath the modern southern channel just south of Government Island. Also notable is a sheet of medium sands that extends from 0 feet $\mathrm{msl}$ to about -40 feet $\mathrm{msl}$ all along the profile until it pinches out underneath the southern channel near Marine Drive. Silts and interbedded fine sands occur on the floodplain from Marine Drive south to the southern limit of the cross section. The Mazama ash horizon forms a thin deposit at -51 feet ( -15.5 meters) msl beneath (borings 645, 646, 648, and 649) the southern floodplain sediments.

\section{LITHOLOGIC GRAIN SIZE DATA}

Analysis of grain size partitioning was performed for 54 of the borehole records in an attempt to delineate how much sand, silty sand, sandy silt, and silt, was distributed throughout the Holocene fill of the LCRB. Also, did grain size distribution change with respect to subsurface elevation within the basin? The data presented in Appendix D allows us to examine the percentages of sand, silty sand, sandy silt, and silt distributed for the length of each core log, and further partitioning of the sediments into elevation intervals allows us to inspect the lithologic variations with subsurface elevation. The results indicate that $54.7 \%$ of the total LCRB sediments are sand size (or larger) sediments (> $0.075 \mathrm{~mm}$ ); 
$17.5 \%$ are silty sands; $14.8 \%$ are sandy silt; and $13.0 \%$ are silt size or finer ( $<0.075 \mathrm{~mm}$ ). The grain size distribution does not increase or decrease appreciably with respect to changes in subsurface elevation. Throughout the entire elevation range the sand sized grains are the dominant component of the infilling sediments. The percentage of silty sand, sandy silt, and silt, generally ranged from 5\% to $25 \%$ for the respective subsurface elevation interval for each lithologic component. Never did the percentage of any one of the three finer components exceed the percentage of sand within the respective interval. Also, the percentage of sand was usually greater then 50 percent. The combined total of the other three components only exceeded the percentage of sand for the 0 to -33 feet $(0$ to $-10 \mathrm{~m}),-164$ to -197 feet $(-50$ to $-60 \mathrm{~m})$, and -197 to -230 feet $(-60$ to $-70 \mathrm{~m})$ intervals, and in these intervals the amount exceeded was minimal. This suggests that the Columbia River has had sufficient energy to transport and bypass sands and finer grained sediments through the LCRB throughout Holocene time. This also suggests that the Columbia River has functioned as a source of sands to the littoral zone rather than a sink during the Holocene period.

\section{VOLUME OF BASIN FILL}

The volume of Holocene fill in the LCRB was calculated for twelve depth intervals from the isopach maps. The 
resulting sedimentary volumes for each interval appear in Table V.

Figure 25 is a plot of the cumulative volume of sedimentary fill $\left(\mathrm{Km}^{3}\right)$ plotted against the average depth below present sea level (in meters) for each depth interval. Also plotted is a best fit line that displays the volume increase with decreasing depth. The total volume of fill is calculated to be $74.57 \mathrm{Km}^{3}$ in the LCRB. This total volume of sediment infilling is most likely a conservative estimate because the western boundary for the isopach map was derived from extending a line from the southern tip of Cape Disappointment, across the main channel axis to Clatsop spit, then projecting the line south, southeast through warrenton Oregon where the boundary line intersects the most northwestern extent of the older Pleistocene terraces (Neim and Neim, 1985) in northwest Clatsop County. This southwest boundary intersection coincides with the 3500 year old shoreline of Rankin (1983) and nearly eliminates the clatsop dunes region from being incorporated into the volume of fill estimate. Also, a seismic profile located at the mouth of the river suggests that the depth of sedimentary fill may be 130 meters as previously mentioned. The plot of cumulative volume of fill vs. depth below sea level (Figure 25) displays a nearly linear relationship. The above discussion of sedimentary infilling is primarily based on the cumulative volume of fill calculations and general observations from borehole records. To accurately assess the 


\section{TABLE V}

HOLOCENE SEDIMENT VOLUME CALCULATIONS

$\begin{array}{lccc}\begin{array}{c}\text { Depth } \\ \text { Interval } m\end{array} & \begin{array}{c}\text { Area }\left(\mathrm{KM}^{3}\right) \\ \text { Per Interval }\end{array} & \begin{array}{c}\text { Volume } \\ \text { of total } \\ \text { fill }\end{array} & \begin{array}{c}\text { Cumulative fill } \\ \text { Volume }\left(\mathrm{KM}^{3}\right)\end{array} \\ 10-10 & 121.3 & 0.61 & 74.57 \\ 20-30 & 104.8 & 1.57 & 61.71 \\ 30-40 & 134.4 & 3.36 & 49.99 \\ 40-50 & 151.4 & 5.30 & 39.46 \\ 50-60 & 145.1 & 6.53 & 30.36 \\ 60-70 & 121.5 & 6.68 & 22.74 \\ 70-80 & 113.7 & 7.39 & 16.45 \\ 80-90 & 102.3 & 7.68 & 11.35 \\ 90-100 & 85.4 & 7.26 & 7.32 \\ 100-110 & 83.9 & 7.97 & 1.23 \\ 110-120 & 75.3 & 7.91 & 0.54 \\ & 107.1 & 12.32 & \end{array}$




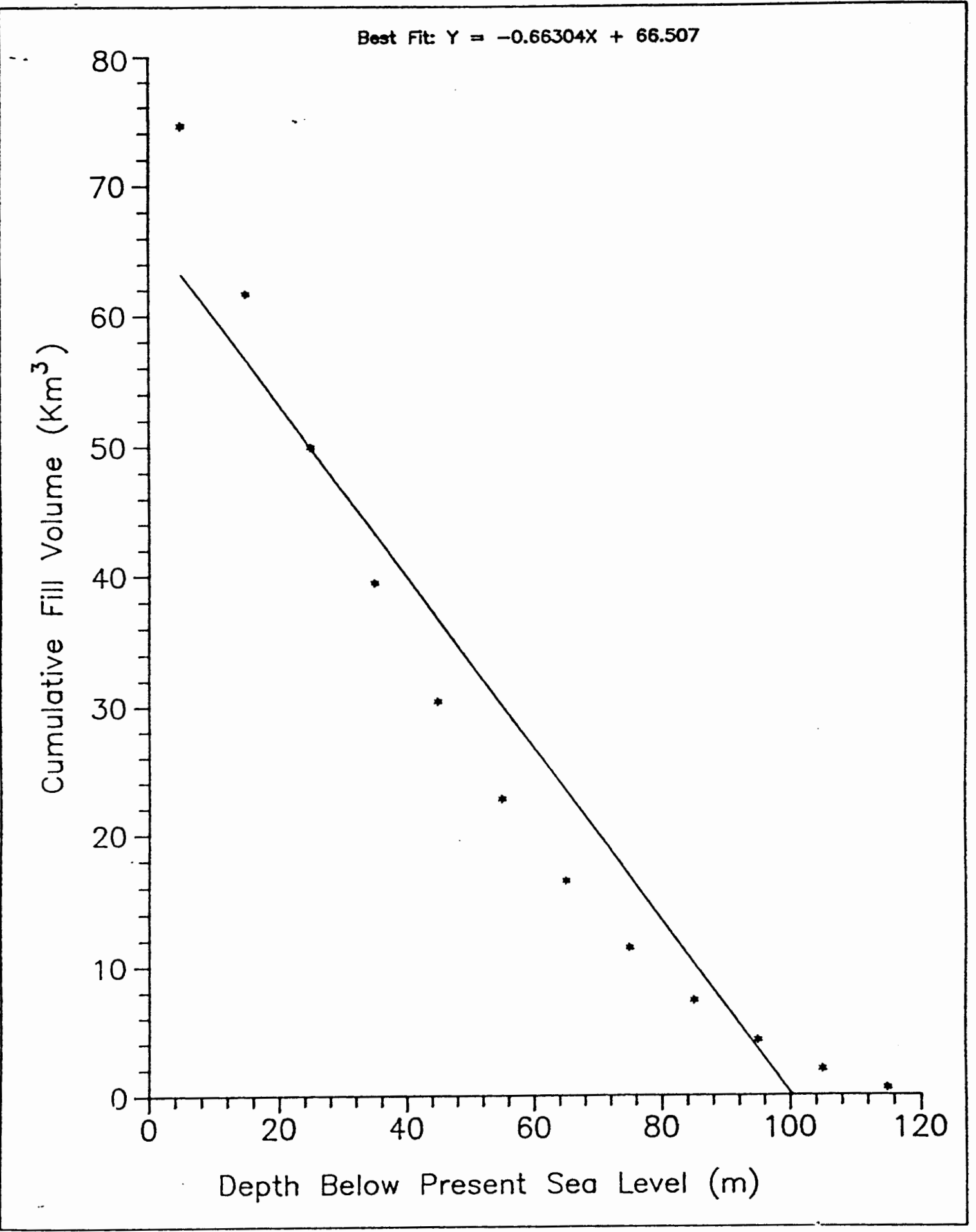

Figure 25. Volume of sedimentary fill vs depth for the lower Columbia River basin. 
ratio of sediment accumulation through time in the LCRB it is necessary to address the rate of sediment accumulation.

\section{RATE OF SEDIMENT ACCUMULATION}

A total volume of $74.57 \mathrm{~km}^{3}\left(7.457 \times 10^{10} \mathrm{~m}^{3}\right)$ of sediment has accumulated in the LCRB since the time of the catastrophic floods, about 12 - $13 \mathrm{ka}$. This volume estimate gives us a useful measure for characterizing the rate of sediment infilling of the LCRB during the latest Pleistocene and Holocene time. These sediment accumulation rates allow us to address some important questions about the Columbia River fluvial system. (1) Do modern estimates of sediment discharge reflect the past records of sediment discharge? (2) What are the effects of flow regulation (dams, channelization, etc.) on the sediment discharge rate? (3) How might changes in sediment retention rate in the Columbia River have affected sediment supply to coastal areas adjacent to the Columbia River during the Holocene period?

A comparison of past retention rates versus present discharge rates can be calculated and compared in the LCRB. Table VI shows the calculated values for the comparison of present discharge rates verses depositional volume. A total volume of $7.457 \times 10^{10} \mathrm{~m}^{3}$ of sediment has been deposited in the LCRB since the last of the catastrophic floods. Waitt (1985) estimated the last flood event at 12,700 years bp. This corresponds to an annual depositional rate of $5.87 \times 10^{6} \mathrm{~m}^{3} / \mathrm{yr}$ 


\section{MODERN DISCHARGE RATES HINDCAST TO PAST DEPOSITIONAL RATES}

\begin{tabular}{|c|c|c|c|}
\hline & $\begin{array}{l}\text { Discharge } \\
\text { Annual Rates } \\
10^{6} \mathrm{~m}^{3} \mathrm{yr}^{-1}\end{array}$ & $\begin{array}{l}\text { Deposition } \\
\text { Annual Rates } \\
10^{6} \mathrm{~m}^{3} \mathrm{yr}^{-1}\end{array}$ & $\begin{array}{l}\text { Total Volume } \\
\text { of Deposition } \\
10^{10} \mathrm{~m}^{3}\end{array}$ \\
\hline \multicolumn{4}{|l|}{$\frac{\text { CREDDP }}{1868-1934^{*}}$} \\
\hline $\begin{array}{l}1868-1934^{*} \\
\text { sand fraction }\end{array}$ & $\begin{array}{r}14.0 \\
7.0\end{array}$ & $\begin{array}{l}1.4 \\
0.7\end{array}$ & $\begin{array}{l}1.78 \\
0.89\end{array}$ \\
\hline $\begin{array}{l}1864-1981 \\
\text { sand fraction }\end{array}$ & $\begin{array}{r}11.8 \\
5.5\end{array}$ & $\begin{array}{l}1.18 \\
0.55\end{array}$ & $\begin{array}{l}1.50 \\
0.70\end{array}$ \\
\hline $\begin{array}{l}\text { This Study } \\
\text { Total (12,700 yrs) } \\
\text { Pre Mazama ( } 5855 \text { Yrs) } \\
\text { Post Mazama (6845 yrs) }\end{array}$ & $\begin{array}{l}58.7 \\
85.4 \\
35.9\end{array}$ & $\begin{array}{l}5.87 \\
8.54 \\
3.59\end{array}$ & $\begin{array}{l}7.457 \\
4.999 \\
2.458\end{array}$ \\
\hline \multicolumn{4}{|c|}{$\begin{array}{l}\text { \# Assumes } 10 \% \text { bedload, with } 100 \% \text { of bedload deposited within the system. } \\
\text { Does include contributions from the Willamette, but not Cowlitz, Lewis, and other } \\
\text { tributaries below Vancouver Washington. Willamette River contribution uses an average of } 1.2 \\
\text { milion tons y }{ }^{-1} \text { (based on USGS, unpublished data, WY } 1963-1964 \text { (Sherwood and others, 1990). }\end{array}$} \\
\hline
\end{tabular}


through the last 12,700 thousand years. Assuming that $10 \%$ of the total sediment load is bedload and $100 \%$ of the bedload is deposited in the LCRB system, this corresponds to an annual total (including suspended load) sediment discharge rate of $5.87 \times 10^{7} \mathrm{~m}^{3} / \mathrm{yr}$. To further characterize the late Quaternary sedimentary deposition rates we can use the Mazama ash layer marker to partition the LCRB sedimentary fill into pre-mazama and post-mazama time periods. For example, we use the date of 6845 years bp (Bacon, 1988) as the time marker, and the 20 meter ( 65.6 feet) depth interval as the depth of the ash bed, (Appendix C) as the pre versus post Mazama fill volume depth horizon. For the pre-mazama time period the annual rate of deposition is $8.54 \times 10^{6} \mathrm{~m}^{3} \mathrm{yr}^{-1}$. For the post mazama period the rate is $3.59 \times 10^{6} \mathrm{~m}^{3} \mathrm{yr}^{-1}$ of sediment deposition. This shows a decrease in depositional volume by a factor of 2.38 from the pre-Mazama to post-Mazama time intervals. Peterson and Phipps (1992) performed a similar study at Grays Harbor, Washington. They calculated a four-fold decrease in average basin sediment accumulation rate between the early and late Holocene period for Grays Harbor. This study (Columbia River) calculated a 2.38 times decrease in sediment deposition rate for the late Holocene (post-Mazama) period.

In the CREDDP study Sherwood and others (1990) estimated the modern total sediment discharge rate (within historic 
time, 1868-1981) for the Columbia River to be $1.13 \mathrm{x} 10^{7} \mathrm{~m}^{3} / \mathrm{yr}$ (Tables II and Table III). The pre-regulation (1868-1934) sediment discharge rate is estimated to be $1.4 \mathrm{X} \quad 10^{7} \mathrm{~m}^{3} \mathrm{yr}^{-1}$ (Table III). The sediment discharge rate from my basin fill calculation $\left(5.87 \times 10^{7} \mathrm{~m}^{3} / \mathrm{yr}\right)$ suggests that the prehistoric rate is larger by a factor of 4.97 times (relative to the CREDDP historic value) and 4.19 times (relative to the preregulation value). Factors of 4.97 and 4.19 times are substantial differences and these values show a major discrepancy between the reported modern discharge rates compared to the discharge rate derived from the geologic record. How can these differences in depositional rate be explained?

To address the differences between the modern discharge rate calculation and the geologic record calculation we need to look at the factors that influence each estimate. The CREDDP study (Sherwood and others, 1990) based its calculation on a heuristic model for predicting sediment discharge from riverflow measurements, and from direct measurements of sediment discharge along the Columbia River. Their value of $11.8 \times 10^{6} \mathrm{~m}^{3} \mathrm{yr}^{-1}$ was calculated from hindcast measurements from water years 1878 to 1981 (see Table III). The estimate of $5.87 \times 10^{7} \mathrm{~m}^{3} / \mathrm{yr}$ from this study is based on a total volume of $74.28 \times 10^{10} \mathrm{~m}^{3}$ deposited over a period of 12,700 years and assumes that bedload is only $10 \%$ of the total sediment load 
and that $100 \%$ of the bedload is deposited in the system. Both calculations have their strengths and weaknesses.

The primary strength of CREDDP's discharge rate calculation is that it incorporated direct measurements to augment their model. A major weakness is that the direct measurements were performed for a short period of time (19641970) and then incorporated into a model to project a longer period of time. Also, these measurements of sediment discharge rate and riverflow were performed during the historic period which has been a time of major river modifications such as irrigation removal, flow regulation, and dam construction for both the main stem of the Columbia River and along many of its tributary river systems. I note that the CREDDP values were not designed for projecting past prehistoric discharge rates. One of the major problems this study encountered is that the discharge rates reported for the Columbia River are barely sufficient to fill the known volume of the LCRB. To fill the basin using CREDDP values we need to assume amounts of deposition greater then $60 \%$ of the total discharge for the pre-Mazama period and amounts of deposition greater than $30 \%$ for the post-Mazama period. The lack of silt and clay in the Holocene fill argues against such large percentages of total sediment load deposition.

The primary strength of the discharge rate calculation from this study is that it incorporates the known volume of fill and sediment grain size distribution for the post 
catastrophic flood period, therefore negating the short time interval used by the CREDDP study.

There are multiple possibilities for the discrepancies in discharge rate value for the brief historic record (CREDDP) value versus the longterm geologic record value (this study). The engineered features such as dam construction, flow regulation, and irrigation withdrawal could dampen the historic value. Flow regulation in modern times has reduced peak flow rates (floods) along the Columbia River and its tributaries when the river is capable of transporting the greatest amount of sediment. Conversely, flow regulation has increased the discharge rate during low flow periods. The geologic record discharge rate value suggests that past sediment discharge was most likely greater. Waitt (1985) noted that while the last catastrophic "large" flood was estimated to occur about 12,700 years ago, the 11,250 \pm 250 Glacier Peak ash layer G (Table I) was overlain by smaller late stage floods that followed deglaciation of the Columbia River drainage basin. These late stage floods were capable of transporting and depositing sediment in the LCRB. However, back filling of the LCRB occurred in response to marine transgression, which did not significantly influence the LCRB until after $11,000 \mathrm{bp}$ (Figures 7 and 8).

Another potentially major contributing sediment source to the LCRB that is accounted for in the volumetric analysis from this study, but not accounted for in the CREDDP estimates, 
involves the contributions of infrequent yet catastrophic input of the Cascade volcanic eruptions and lahars. All of the values reported in Table III are measurements from Vancouver, Washington. This measuring station essentially records the eastern sub-basin sediment contributions, yet essentially eliminates the contributions from the Cowlitz, Lewis, and other tributaries down river from this station. The CREDDP study did use data (1963-1964 -one water year) for the Willamette River and projected that single year's data back in time for the cumulative time periods calculations. Simenstad and others (1990) reported that "although the coastal subbasin (of the Columbia River, west of the Cascade Range) occupies $8 \%$ of the total drainage basin, it contributes $24 \%$ of the total riverflow due to the large excess of precipitation over evaporation, and the mild, wet winters." If sediment discharge yields are proportional to riverflow, the coastal sub-basin certainly contributes a significant, and partially unaccounted for, amount of sediment to the LCRB.

The May 18, 1980, eruption of Mount St. Helens shows how volcanic events can supply substantial amounts of sediment to the LCRB from these volcanic arc tributaries. Fairchild and Wigmosta (1983) estimated the amount of sediment in the mudflows that reached the Toutle and Cowlitz River confluence to approach nearly $100 \mathrm{X} 10^{6} \mathrm{~m}^{3}$ in volume. Schuster (1981) reported that $34 \times 10^{6} \mathrm{~m}^{3}$ of sediment accumulated in the Columbia River adjacent to the mouth of the Cowlitz River 
immediately after the eruption, and the Cowlitz continues to contribute an unusually high rate of sediment to the LCRB. Table VII (Abby, 1989) lists the sediment discharge rate for the Cowlitz River following the 1980 eruption of Mount St. Helens.

The disproportionately high volume of sediment input to the LCRB following the 1980 eruption shows how past volcanic events can influence the sediment supply to the LCRB. Throughout the Holocene period many volcanic events have input large amounts of sediment to the LCRB, as shown by the Mazama ash bed occurrence. Table I lists past late Quaternary volcanic events that have erupted "large volumes" of tephra. Certainly, even lesser eruptive events, not listed in Table I, from local Cascade volcanos have input substantial amounts of sediments into the basin. Also these large amounts of sediment influx can most likely endure for decades (or longer through reworking) before the local fluvial system returns to its normal sediment discharge level.

An alternative hypothesis for the large discrepancy in the modern versus geologic records based discharge rate values is that the LCRB functioned as a sink and received substantial amounts of sediment from the marine environment during the early stages of the marine transgression. However, evidence for this hypothesis is not substantial. The dominance of sand sized sediments throughout all depths of the LCRB suggests 
TABLE VII

SEDIMENT CONTRIBUTION OF THE COWLITZ RIVER TO THE COLUMBIA RIVER AFTER THE 1980 ERUPTION OF MOUNT ST. HELENS

$$
\text { Sediment yield }\left(10^{6} \mathrm{~m}^{3}\right)
$$

\begin{tabular}{|c|c|c|c|}
\hline Water Year & Total & Bed Material & Bed $\%$ of Total \\
\hline$\overline{1980}$ & $\overline{30.6}$ & $\mathrm{~N} / \mathrm{A}$ & $\mathrm{N} / \mathrm{A}$ \\
\hline 1981 & $\mathrm{~N} / \mathrm{A}$ & $\mathrm{N} / \mathrm{A}$ & $\mathrm{N} / \mathrm{A}$ \\
\hline 1982 & 17.59 & 0.76 & 4.3 \\
\hline 1983 & 16.06 & 2.29 & 14.3 \\
\hline 1984 & 7.65 & 1.53 & 20.0 \\
\hline 1985 & 4.59 & 1.53 & 33.3 \\
\hline 1986 & 3.82 & 1.53 & 40.0 \\
\hline 1987 & 3.82 & 1.53 & 40.0 \\
\hline
\end{tabular}

Where bed material is grains larger than very fine sand ( $>0.125 \mathrm{~mm}$, excluding very fine sand). 
that sufficient energy for fluvial depositional processes has allowed for throughflow of river sediments to the marine side throughout the Holocene marine transgression.

The effects of past and present sediment supply from the Columbia River system to the adjacent marine environment can also be assessed independently. Rankin (1983) showed that the shoreline along the northern Oregon coast at 3500 years b.p. had moved eastward with the marine transgression and was up against the uplifted Pleistocene terraces. Since that time the shoreline has prograded westward to form Clatsop Spit. This shoreline progradation shows that there has been a sufficient amount of Columbia River sediment to supply the adjacent coastline since 3500 years bp. Also, Peterson and Phipps (1992) indicated that the barrier spit in Grays Harbor, Washington, is supplied by Columbia River sands and has been accreting vertically for the last 9000 years. This further supports the idea that the Columbia River has been a source of sands to nearby coastal areas rather than a sink.

To accurately assess the rate of sediment accumulation a sediment level verses age curve needs to be constructed.

A preliminary late Holocene sediment level curve for the LCRB appears in figure 26. Table VIII lists the dates used in figure 26 . Note that the two oldest dates are based on the age of geologic occurrence as opposed to radio-carbon dates.

Three trends are plotted in figure 26. The curved line 


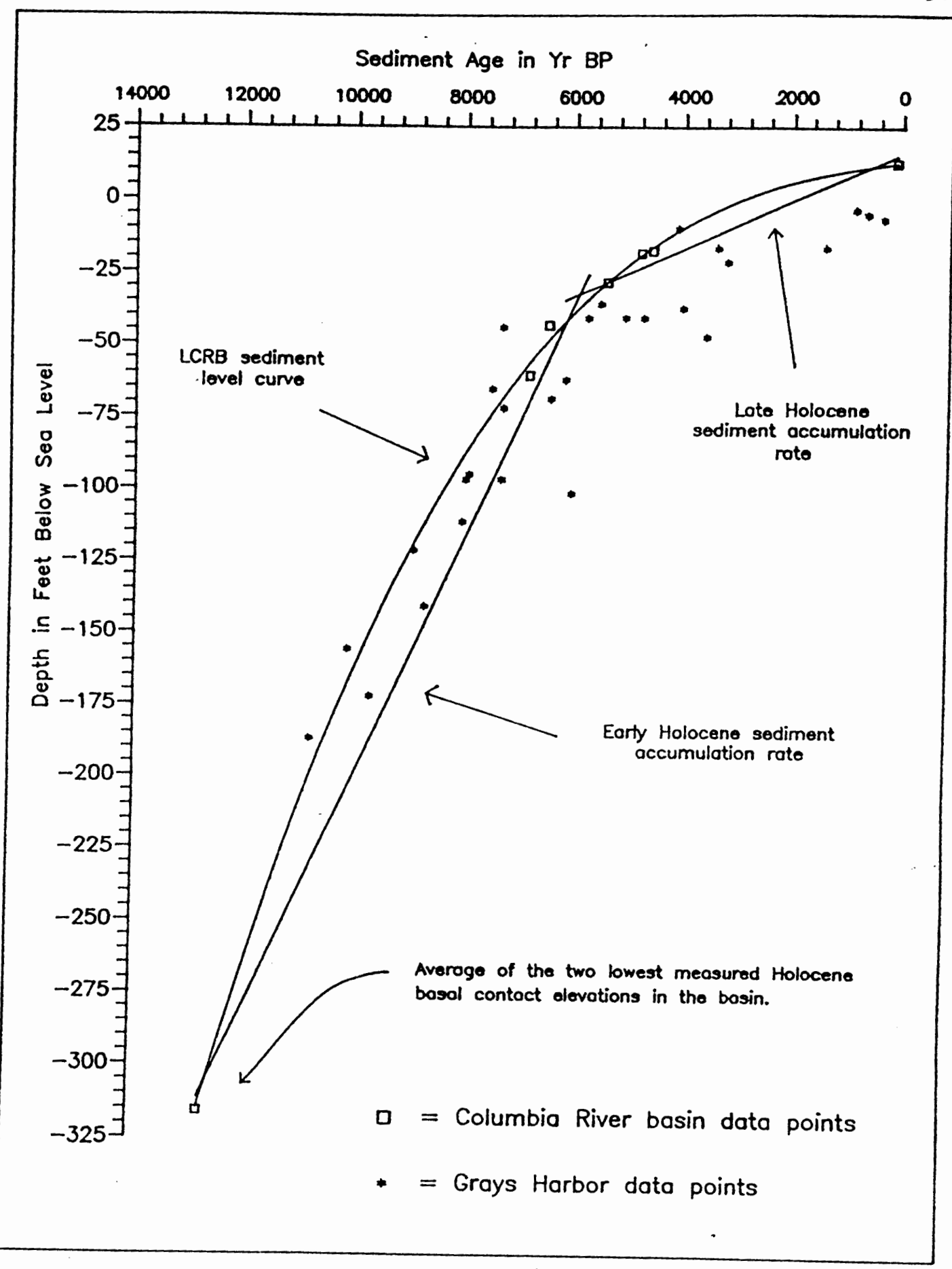

Elqure 26.

Predicted sediment oge-level curve for the lower Columbia River basin (boxes) compared to Groys Harbor sediment depth-age data (asterisks). 
TABLE VIII

\section{SEDIMENT AGE ELEVATIONS}

$\begin{array}{ccc}\text { Site } & \text { Date (RCYBP) } & \text { Elevation } \mathrm{ft} \text { (msl) } \\ 564^{\mathrm{a}} & 100 \pm 70 & +12.87 \\ 564^{\mathrm{a}} & 4590 \pm 70 & -17.58 \\ \star^{*} & 4800 \pm 90 & -18.5 \\ \star^{\mathrm{b}} & 5420 \pm 100 & -28.5 \\ \text { Mazama }^{\mathrm{c}} & 6490 \pm 100 & -43.5 \\ 262 \& 260^{\mathrm{d}} & 6845 & -60.96 \\ & 12,700 & -316.0\end{array}$

* Data from P.E. Hammond (1975). Samples from two different boreholes on the west bank of the willamette River north of Linnton Oregon.

a Sample from borehole near N. Marine drive, Portland, Oregon.

b Sample from carbonized wood within a Mazama ash layer.

c Average elevation for all of the Mazama ash data points. RCYBP from Bacon, 1983.

d Elevation is an average from these two boreholes and represents the two lowest known contact elevations. RCYBP date from Waitt, 1985. 
that extends through the boxed points is the apparent sediment level curve for the LCRB. The lower straight line segment represents the slope of sediment accumulation rate for the pre-Mazama time period. The upper straight line segment represents the sediment accumulation rate slope for the postMazama time period. The square boxes are data points from the Portland basin area of the ICRB. The smaller points (asterisks) are data points from Grays Harbor that Peterson and Phipps (1992) used to construct a similar sediment level curve for that estuary. Note that generally the Columbia River points (boxes, $0-7 \mathrm{ka}$ ) plot at a slightly higher elevation for a given depth, than the Grays Harbor estuary points. This relation is likely due to higher average elevation of the fluvial flood plain in the upper reaches of the LCRB, as compared to the tidally dominated depositional system of the Grays Harbor estuary. As previously mentioned, the upper five points of the LCRB data points were determined by radio-carbon dating methods. The second to lowest box point is plotted from the average elevation of all the Mazama ash points (Appendix C) versus the age of the Mazama eruption at 6845 years ago (Bacon and Druitt, 1988). The lowest boxed point at -316 feet $(-96.3 \mathrm{~m})$ and 12,700 years $\mathrm{bp}$, is an average from the two lowest elevations in boreholes 260 and 262 (Appendix B) in Longview, Washington and near Kalama, Washington respectively, and represents the lowest elevation occurrence for the Holocene contact in the upper basin of the LCRB. This point 
was used as a reference marker for the Columbia River base level at the onset of the Holocene marine transgression in the LCRB. Note, these two base level points are greater then 60 miles $(97 \mathrm{~km})$ inland from the modern river mouth location. Most likely the base level was lower in the lower river reaches.

The shape of the sediment level curve for the LCRB closely resembles some eustatic sea-level curves reported for the Holocene (Atwater and others, 1977; Glenn, 1978; Kraft, 1971; Peterson and Phipps, 1992; Figures 7, 8 and 9). The curve shows a steep rise during the early Holocene period followed by a significant decline in the sedimentation rate during the late Holocene. The lower line segment learly Holocene) slope corresponds to an accumulation rate of 12.6 $\mathrm{mm} / \mathrm{yr}$. Peterson and Phipps (1992) calculated a similar 12 $\mathrm{mm} / \mathrm{yr}$ accumulation rate for the Grays Harbor estuary. The upper line segment represents the late Holocene sediment accumulation rate. The slope of this line corresponds to a rate of $2.5 \mathrm{~mm} / \mathrm{yr}$. A comparison of the two sediment accumulation rates shows that the post-Mazama (late Holocene) sediment accumulation rate declined by a factor of five times versus the pre-Mazama, early Holocene, rate in the LCRB.

There is still much uncertainty as to the level of fluvial-esturine deposition throughout the LCRB. Additional $\mathrm{C}^{14}$ age data needs to be collected for the sediment levels within the LCRB, especially in the lower reaches of the estuary, and 
throughout the basin below the depth of the Mazama ash layer. These data are needed to further evaluate the predicted sediment level curve from this study and to constrain sedimentation rates in the different portions of the basin. 


\section{DISCUSSION}

Within the Columbia River estuary Holocene fill, the Mazama ash layer provides a regional key stratigraphic interval that roughly divides the sedimentary deposits into early and late Holocene time. This time interval, about 6845 years bp, is particularly important as it roughly corresponds to a major change in rate of sea level rise (fast: greater than 7000 years bp, slow: less than 7000 years bp).

The primary chronostratigraphic marker bed is the Mazama ash layer. No previous literature for the ash bed has been published. Geochemical analysis of the ash layer has been compiled by Dr. Marvin Beeson (Portland State University), Dr. Larry Kittleman (University of Oregon), and by the author for this study.

\section{MAZAMA ASH GEOCHEMISTRY}

The results of the tephra source analysis shows that the suspect Mazama ash horizon is indeed derived from the climatic eruption(s) of Mount Mazama 6845 years ago. Appendix A contains the geochemical data tables (Tables $\mathrm{A}-1$ and $\mathrm{A}-2$ ) and graphs (Figures A-1 through A-16) used for analysis. The circled fields labeled "Mazama Ash" and "Mt. St. Helens tephra" in Figures A-1 through A-16 (Appendix A) are for the 
samples known to have been derived from these two potential source volcanos.

Rare earth elements are normally somewhat concentrated in glass relative to co-existing crystals, and it is unlikely their abundances would be significantly modified by weathering processes (Randle, and others, 1971). Therefore, La, Ce, and Sm should be good discriminants judging from the distinctive ranges in tables $A-I$ and $A-I I$. One should note that to a first approximation the elements of this group are coherent. Plots A-I through A-6 (La vs Sm, Ce vs Sm, and La vs Ce) of Appendix A clearly display that both the Portland area and Longview/Astoria area ash occurrences are distributed around known Mazama ash points. Clearly these points were not derived from Mount St. Helens or Glacier Peak tephras because they all contain higher concentrations of Lanthanum, Samarium, and Cerium, yet the rare earth elements do not distinguish the suspect ash samples from the sediment found in the Portland basin.

Thorium is also a useful discriminant in ash samples. Th is also concentrated in glass relative to co-existing crystalline phases. Unlike the situation in holocrystalline rocks, where this element may be located at grain boundary sites and readily removed during weathering, Th in these ash samples would probably not be leached out easily due to its low geochemical mobility (Randle, and others, 1971). Its abundances vary from one group of ashes to another but the 
ranges in a particular set are narrow. The thorium contents of the Mt. St. Helens and Glacier Peak sample provide a clear distinction between these two sets and the Mazama ash in our data (plots $A-7 \& A-8)$.

Hafnium (plots $A-9 \& A-10$ ) also seems to be useful. Like Thorium, it is concentrated in glass and would not be expected to be mobilized during weathering. Hafnium is also useful for distinguishing the ash samples from the Portland area sediment and Glacier Peak tephra because all of the ash samples show a higher concentration of Hafnium compared to the sediment and Glacier Peak tephra. The Hafnium vs Thorium ratios also show a coherent grouping around the known Mazama points.

The transition metals $\mathrm{Co}, \mathrm{Fe}$, and $\mathrm{Sc}$ are all concentrated in crystalline phases relative to glass. Therefore, these elements best distinguish the separation of the ash samples from the sediment sample and the near source Mount st. Helens sample set. Plots A-11 through A-16 display that the ash samples had generally lower concentrations of iron, cobalt, and scandium. On the basis of transition metal element concentrations the Portland, Longview, and Astoria area ash occurrences can be distinguished from the Mount st. Helens set of ashes and also suggest that these samples were not derived from the reworking of previously deposited sediments.

Based on the above observations the ash samples from the borings in the Portland, Longview, and Astoria regions were 
certainly derived from Mt. Mazama as opposed to either a Mt. St. Helens or Glacier Peak source.

Analysis of the target ash layer indicates that it was derived from the climatic eruption of Mount Mazama 6845 years ago. The data in Appendix A show little geochemical variability between the data points from individual sample sets. Also, there is little variability between sample sets from the different analysts. This lack of variability indicates that results show good geochemical correlation between multiple analysts in independent experiments. The significance of identifying the geochemical character of the ash bed in the LCRB allows it to be used as a marker horizon. Combined with its widespread distribution and known age of deposition, it can be used as a key chronostratigraphic marker within the Holocene deposits of the Columbia River basin.

ANCESTRAL RIVER VALLEY MORPHOLOGY AND BASIN FILL

The basin isopach maps (Maps 1 through 4) display the sedimentary infilling and subsequent morphology of the LCRB and the adjacent tributaries. The maps (especially Map 1) illustrate the generally narrow river valley and steep incised slopes along the lateral margins of the valley. This narrow channel axis form suggests that the Columbia River has been confined to its present incised canyon with only minor lateral migration. 
The isopach maps show some very intriguing subsurface features. Depths below the 110 meter contour represents the maximum thickness and lowest elevation occurrences for the Holocene alluvium. The base elevation of nearly -120 meters is consistent with pre-Holocene lower global sea level stands during the late Pleistocene (Bloom, 1983). Also, known late Pleistocene contacts from boreholes at nearly -100 meters msl occurring more then 60 and 70 miles upriver (Longview and Kalama, Washington) give supporting evidence for a Holocene base level near -120 meters $\mathrm{msl}$ in the lowest portions of the LCRB. The isopach contours also show that the Columbia river has excavated a deep valley with steep lateral margins prior to deposition of the Holocene alluvium.

In the vicinity of Longview, Washington, the Cowlitz River is a major tributary of the Mount St. Helens area, capable of transporting large volumes of primary or reworked volcanic debris to the Columbia River system. The Cowlitz River delta at Longview shows evidence of progradation out into the Longview basin. The isopach contours (Map 2) show that the former Columbia River channel axis flowed beneath the present site of Longview on the modern Cowlitz River delta. The timing of the Columbia River channel shift to the southern margin of the Longview basin is uncertain but probably coincided with the eruptive sequences (Table III) that deposited the set $J(8300 \pm 300 \mathrm{bp})$ tephras or during the set 
$Y(3350-3510 \pm 240 \mathrm{bp})$ and/or set $\mathrm{P}(2580-2930 \pm 250 \mathrm{bp})$ eruptive sequences.

Also of note in the vicinity of Longview, Washington, the drill holes penetrated a series of small basalt knobs. The knobs trend in a northwest to southeast alignment which suggests the presence of a structural trend, possibly a fault. The knobs appear to have a streamlined form with their long axis parallel to the direction of riverflow. The streamlined form is likely the result of scouring by lower river elevations (down cutting) and/or the catastrophic flood events that swept through the Longview basin during the late Pleistocene. Also of note is the deep $(>60 \mathrm{~m})$ channel just north of Mount Solo in Longview. This channel could represent the presence of a bifurcation of the main channel axis around Mount solo caused by either the catastrophic floods or subsequent flow of the early Holocene Columbia River.

Similar to the Cowlitz River system in Longview, the Lewis River delta near Woodland, Washington has also prograded out into the Columbia River valley. Map 3 shows that the present position of the Columbia River channel occupies the western margin of the valley. But, the isopach contours suggest that the Columbia River formerly occupied the central valley axis flowing underneath the present location of the modern Lewis River delta. Timing for this lateral channel shift is uncertain but it most likely occurred during progradation of the Lewis River delta during the Mount st. 
Helens eruptive Set $J$, set $Y$, or Set $P$, eruptive sequences as stated above.

In the Portland area the isopach data (Map 4) suggests both scouring and depositional features. Along the western margin of Sauvie Island (Maps 3 and 4) the isopach contours show a shallow (10-20 meters beneath the surface) gravel bar aligned in a northwest direction parallel to Multnomah channel that curves northeast near the middle of the island. The drill holes all penetrated coarse grained sediment described as "gravel, cobbles" and occasionally "boulders". This gravel bar may represent an extension of Alameda Ridge in north Portland, a deposition remnant from the catastrophic Bretz flood events. The isopach data indicate a deep channel (greater than 50 meters) beneath the modern Multnomah Channel near the southwest shoreline of Sauvie Island. This channel combined with the gravel bar immediately north (and parallel) to the channel suggests that a portion of the willamette River may have occupied this deep channel either during, or immediately following, the catastrophic floods and subsequently breached the gravel bar to occupy its present channel shortly thereafter. Also, the sediments deposited upon the sauvie Island gravel ridge could possibly represent late Quaternary fine grain facies sediments deposited by the winnowing flood events. Evidence for this idea is suggested by the high topographic position of the sediments. The finer sediments deposited on the gravel bar reach elevations exceeding 50 feet 
(15 meters) above modern $\mathrm{msl}$, peak island elevations reach 70 feet (21 meters) msl. Previous geologic mapping in the Portland basin area has mapped the upper Sauvie Island surface as "Qal" (Trimble, 1963), but historic flood data from the U.S. Army Corps of Engineers indicates that flood elevations have only reached 32.8 feet (1948) and slightly greater during the 1894 flood event. The presence of alluvial sediments above the 50 foot elevation suggests that either pre-historic floods in the Portland Basin have reached above this elevation, or that the sediments deposited on the Sauvie Island gravel bar may actually represent fine-grained facies (Qff) deposits from the late Pleistocene floods. Archeological evidence from recovered artifacts suggests that native Americans were present at least 4,500 years ago on the upper elevations of Sauvie Island. This evidence is based on "artifact form and technology" (Ken Ames, Personal Communication). This archeological evidence further supports my interpretation is that these deposits represent the fine-grained facies deposits from the catastrophic floods. These deposits also show how difficult it is to distinguish between modern flood alluvium and catastrophic flood alluvium based on grain size alone. This example gives a surface analog to a potential problem that may be occurring at depth; how, and where, does one define the Holocene boundary when coarser grained deposits are not present. I should also note that this area is the only 
region within the study area where the upper isopach surface exceeds 40 feet in elevation.

Map 4 also shows the presence of another shallow gravel bar beneath the present location Smith and Bybee lakes in north Portland. The gravel ridge is about 20 to 30 meters below the modern surface level and is aligned parallel to Alameda ridge. This gravel bar is most likely a depositional feature left by the catastrophic floods. The occurrence of coarse-grained facies deposits beneath Sauvie Island and north Portland illustrate the potential for possible large volume aquifers buried beneath the Holocene sediments. Yet, the question of water quantity and quality from these potential aquifers awaits further investigation.

Map 4 shows the presence of two deep (greater than $60 \mathrm{M}$ ) channels beneath the Rivergate area of North Portland extending up the Willamette River drainage system. Either or both of these channels may represent the location where the Willamette River breached the northwestern extension of Alameda ridge.

In the area near the southern extension of the I-205 Bridge the isopach contours indicate the presence of a deep $(80+\mathrm{m})$ scour channel. This channel extends from the borings immediately east from the south end of the bridge and extends westward underneath the Portland Airport where it broadens out and shallows to the level of the main valley floor. Whether this channel is an erosional remnant from the catastrophic 
floods or was formed by the early Holocene Columbia River awaits further investigation. But this feature does suggest a break in slope for the incised lower Columbia River valley because the isopach data indicate that upriver from the scour channel the sediment thickness only reaches depths to 40 meters.

Inspection of the cross sections and sediment partition data (Appendix D) shows that fine sands have been the dominant grain size deposited throughout the lower, middle, and upper portions of the drill core logs. This trend is fairly uniform for the cross sections and is independent of their position relative to the eastern and western portions of the study area. This uniform grain size partitioning suggests that the finer silt and clay size sediments have almost entirely bypassed the lower Columbia River system throughout the Holocene transgression. While local deposits of fine-grained silt and clay size sediments are apparent, their distribution as lenses and thin beds suggests that subsequent channel migrations may have scoured them out during subsequent lateral channel migrations. Sediment bypassing also supports the idea that the lower Columbia River has remained in a nearly stable energy regime and that during Holocene sea level rise. The valley was not a quiet standing body of water dominantly influenced by rapid sea level rise but, rather, an energetic system capable of continuously transporting sediment into and through the lower river basin. If sea level had outpaced 
fluvial infilling, there should be extensive deposits of fine sediments at depth in the lower river valley, but that is not indicated by the drill hole logs, or the sediment partition data. Furthermore, the dominance of sand throughout the length of the lower Columbia River valley indicates that fine sand has also been bypassed through the system throughout Holocene time. These results are consistent with reports of the Clatsop spit progadation (Rankin, 1983) after a decrease in the rate of sea level rise after 7,000 years b.p. . The indications that the Columbia River has been bypassing sands to the marine environment throughout the Holocene is also consistent with the development and vertical growth of the barrier spits at Grays Harbor (Peterson and Phipps, 1992).

The rate of LCRB infilling decreased by more than $50 \%$ from the pre-Mazama to post-Mazama time interval (Table VI). The depth vs fill volume plot displays a near linear relation, suggesting that sediment deposition rate changes were not due to non linear trends of basin volume with depth. Two primary factors could cause the dramatic decrease in sediment depositional rate after 7,000 years bp: (1) a decrease in sediment supply rate or (2) a change in sediment retention rate. A major climatic change in the Pacific Northwest should have closely followed the end of glaciation in the latest Pleistocene-early Holocene time possibly supplying more sediment at the end of glaciation. However, a major decrease in the rate of eustatic sea level rise occurred in the early- 
middle Holocene time at about 7,000 years ago (Bloom, 1983). A decreasing rate of sea level rise could have resulted in a shallowing of the LCRB and bypassing of bedload sediments through the LCRB to the coastal zone. Although additional sediment-level/age curves are needed for the LCRB to discriminate between these two possibilities, the latter is presumed here, primarily due to the predominance of bed load (sand) deposited throughout the Holocene period. Bypassing has apparently been occurring throughout the Holocene period. Therefore, the controls on sediment throughflow appear to dominate sediment deposition rather then variable sediment input. In any case, the sediment accumulation rates are likely to underestimate the sand supply to the LCRB. The dominance of river sand throughout the length of the basin implies significant throughflow of this size fraction throughout the Holocene. The lack of accumulated silts and clays shows that these finer fractions were never effectively trapped in the fluvially dominated LCRB. Estimates of prehistoric total discharge, based on an assumed $10 \%$ bedload, are also likely to under represent actual total sediment discharge, unless bedload accounts for more then $10 \%$ of the total sediment discharge.

The apparent sediment bypassing through the LCRB through Holocene time indicates that the lower Columbia River is not similar to the tidally dominated depositional systems that occur in Grays Harbor and Tillamook Bay. The lower Columbia 
River basin has been a fluvially dominated system throughout the Holocene. The relative base level for fluvial deposition has kept close pace with the rise of the Holocene marine transgression and continued to bypass fine grained sediments. The rate of sediment bypassing has increased in reciprocal proportion to the decrease in sea level rise. 


\section{CONCLUSIONS}

The lower Columbia River basin Holocene sedimentary deposits record the post catastrophic flood stratigraphic development of the river basin during the Holocene marine transgression in the Pacific northwest. From the infilled sedimentary deposits I have recorded the following information: 1) the occurrence of a key chronostratigraphic marker horizon, the Mazama ash bed, and measurements of its thickness and stratigraphic position. 2) A database (Appendix B) of 1487 borehole records has been compiled. This database gives adequate control for construction of four isopach maps that record the depth and volume of infilled sediments for the LCRB. 3) Information derived from this database gives an image of the subsurface basin morphology and the position of the underlying pre Holocene contact surface. 4) Borehole sediment grain-size partitioning has been performed to delineate the general overall vertical grain-size distribution within the LCRB sedimentary deposits. 5) A sediment age-level curve has been constructed, and rates of infilling have been calculated. Finally, 6) we can use the above information to comment on the sediment supply and retention rate, and how these inputs have been affected by the marine transgression during Holocene time. 
The Mazama ash bed occurrence has been identified in 197 boreholes from throughout the LCRB. The ash bed appears in the floodplain sediments of both Oregon and Washington, and extends from Troutdale, Oregon downriver to Warrenton, Oregon. Sedimentary characteristics indicate the ash bed was deposited by fluvial processes in a floodplain environment. The borehole records indicate that the average elevation for the basal contact is -61.0 feet $(-18.6$ meters $)$.

INAA geochemical data from multiple analysts in separate experiments identifies the source of the suspect ash bed. The comparisons indicate the suspect ash to be derived from the climax eruption of Mount Mazama 6845 years ago. Identification of this key marker bed gives a time horizon that allows us to partition the LCRB sedimentary deposits into two distinct time intervals; the pre-Mazama and post-Mazama time periods. This ash bed indicates the average floodplain elevation at the time of deposition.

A comprehensive database (Appendix B) of 1487 borehole records from throughout the LCRB has been compiled. This database gives us sufficient control for delineating the depth and extent of subsurface lithologic contacts for the Mazama ash bed and the Holocene basal contact.

The database was used to construct four isopach maps that show the widespread distribution of the boreholes and resulting isopach contours. The isopach maps display some intriguing subsurface features. The Columbia River valley 
morphology reveals that the river was capable of down cutting a deep incised valley with steep walls prior to the deposition of Holocene sediments during the subsequent marine transgression. The erosional process responsible for downcutting the pre Holocene surface must have been the late Pleistocene Columbia River and culminated about 12,700 years ago with the catastrophic floods. On a local scale, some of the prominent subsurface features displayed by the isopach maps are as follows: 1) The shallow basaltic bedrock knobs that occur beneath the western floodplain of Longview, Washington. These knobs are probably erosional remnants (similar to Mount Solo) formed by the catastrophic floods that swept through the area during latest Pleistocene time. The linear northwest to southeast alignment suggest the possibility of a structural trend (fault?) that runs parallel to these bedrock knobs. 2) The Cowlitz River is one of two major tributaries that originate near Mount st. Helens. It enters the Columbia River at Longview, Washington. The isopach contours indicate that the voluminous sedimentary discharge from the Cowlitz river has prograded outwards the cowlitz delta and subsequently infilled the early Holocene Columbia River channel, forcing the modern channel to the south side of the valley. 3) Similarly, The Lewis River delta about 20 miles further upriver has also prograded outwards infilling the early Holocene Columbia River channel. 4) Further upriver near the confluence of the Willamette River deep subsurface 
channels suggest that this area has been influenced by an early Holocene/late Pleistocene shift in channel structure. A deep 50 meter channel is present along the southwestern portion of Sauvie Island. This channel is probably a former Willamette River channel that was wholly or partially restricted to this position either during or immediately following the deposition of Alameda ridge during the catastrophic flood events. Also, near the confluence of the Willamette River with the Columbia River, two $60+$ meter channels are present. These channels were probably formed during or soon after the late Pleistocene flood events. Further upriver in the east Portland area near the I-205 bridge site, the Columbia River has excavated a deep $80+$ meter channel. This event also was most likely the result of late Pleistocene scouring.

A total volume of 74.57 cubic kilometers $\left(7.457 \times 10^{10} \mathrm{~m}^{3}\right)$ of sediment has accumulated in the LCRB since the catastrophic floods, about 12,700 years ago. This corresponds to an average annual depositional rate of $5.87 \mathrm{X} 10^{6} \mathrm{~m}^{3} \mathrm{yr}^{-1}$. Using the Mazama ash layer occurrence as a time line the Holocene sedimentary fill can be partitioned into two distinct time intervals. For the pre-Mazama time period the average annual LCRB sediment deposition volume is $8.54 \times 10^{6} \mathrm{~m}^{3} \mathrm{yr}^{-1}$. For the post-Mazama time period the average annual LCRB sediment accumulation volume is $3.59 \mathrm{X} 10^{6} \mathrm{~m}^{3} \mathrm{yr}^{-1}$. These two volumes show that the average annual sediment depositional volume has decreased by a factor 
of 2.38 from the early to late Holocene time. The nearly linear volume of fill versus depth trend indicates that the base level of the LCRB fluvial system has closely kept pace with the Holocene sea level rise.

The volume of fill value can also be used to calculate the past sediment discharge rates. Based on the assumption that $10 \%$ of the sediment in transport is bedload and that $100 \%$ of the bedload is deposited within the system, this study hindcasts an annual fluvial sediment discharge rate of $58.7 \mathrm{X}$ $10^{6} \mathrm{~m}^{3} \mathrm{yr}^{-1}$. For the pre and post Mazama time periods the corresponding discharge rates are $85.3 \times 10^{6} \mathrm{~m}^{3} \mathrm{yr}^{-1}$ and $35.9 \mathrm{X}$ $10^{6} \mathrm{~m}^{3} \mathrm{yr}^{-1}$ respectively. These values are much greater than the modern sediment discharge rates reported by previous investigators. A portion of this large discrepancy can be attributed to the infrequent yet substantial volumes of sediment derived from LCRB tributaries that drain from the nearby Cascade volcanos following eruptive events. These volcanic contributions were essentially unaccounted for by the previous investigators. Also, previous investigations have used discharge calculations from historic times to augment their models. Dam construction and flow regulations on the main stem of the Columbia and many of its tributaries has dampened peak flows when the river is capable of transporting its largest loads. Therefore, the previous investigators may have under estimated the fluvial sediment discharge rates. The remainder of the large sediment volume discrepancy can be 
accounted for by the mid-Holocene adjustment in sediment retention rate attributed to the increased rate of sediment bypassing

Grain size distribution partition data were recorded from the borehole records. The results indicate that $54.7 \%$ of the total infilled sediments are sands, $17.5 \%$ are silty sands, $14.8 \%$ are sandy silts, and $13.0 \%$ are silt size or smaller. The grain size distribution did not change appreciably with respect to increased subsurface elevation. Throughout the entire elevation range sand size grains are the primary component of the alluvial sedimentary deposits. This homogeneous grain size distribution shows that throughout Holocene time the Columbia River has had sufficient energy to transport sand sized sediments into and through the LCRB. This also shows that the river has functioned as a source of sands to the adjacent nearshore environment rather than a sink for littoral sands during Holocene time.

A Holocene sediment age-level curve for the LCRB has been constructed from chronologic markers (radiocarbon dates and contact elevations) within the unconsolidated sedimentary deposits. The sediment level curve (Figure 26) closely resembles eustatic sea level curves reported from other Pacific coast estuaries. The curve shows a steep rise during the early Holocene followed by a pronounced decline during late Holocene time. The slope of the early Holocene line and late Holocene sediment level line shows the rate of sediment 
accumulation for these two respective time intervals. The early Holocene sediment accumulation rate is $12.6 \mathrm{~mm}$ per year, and the late Holocene accumulation rate is $2.5 \mathrm{~mm}$ per year. These rates correspond to a decline in sediment level accumulation of 5 times. This decreasing sediment accumulation rate indicates that fine grained sediments are not being retained in the basin but are continuing to be transported through the LCRB. It also clearly displays the adjustment in sediment deposition rate that occurred in mid-Holocene time.

A nearly linear trend in volume of sedimentary fill versus depth combined with a significant decrease in the rate of sediment accumulation levels shows that the sedimentary deposits of the LCRB have closely kept pace with the Holocene sea level rise. This demonstrates that the Columbia River has been a fluvially dominated depositional system throughout the Holocene marine transgression. As the sea level rise decreased during mid-Holocene time the fluvial system responded by increasing its throughput of fine grained sediments. Finegrained sediments continue to be transported through the lower river basin and deposited offshore. 
References Cited

Abbe, T., 1989. Sediment Dynamics of the shore slopes of the Puget Island reach of the Columbia River, Oregon and Washington. Unpublished M. S. Thesis, Portland State University, Portland, Oregon, $231 \mathrm{p}$.

Allen, J.E., 1975. Volcanos of the Portland area, Oregon. The Ore Bin, 37: 145-157.

Allen, J.E., Burns, M., and Sargent, S.C., 1986. Cataclysms on the Columbia. Timber, Press Publishing Co., Portland, Oregon. $211 \mathrm{p}$.

Ando, M. and Balazas, E.I., 1979. Geodetic evidence for aseismic subduction of the Juan de Fuca Plate. Journal of Geophysical Research, 84: 3023-3028.

Atwater, B.F., Hedel, C.W., and Helley, E.J., 1977. Late Quaternary depositional history, Holocene sea level changes, and vertical crustal movement, Southern San Francisco Bay, California. U.S. Geological Survey Professional Paper 1014.

Atwater, B.F., 1987. Evidence for Great Holocene earthquakes along the outer of Washington State. Science, 36:942-944.

Bacon, C.R., 1983. Eruptive history of Mount Mazama and Crater Lake caldera, Cascade Range, U.S.A. Journal of

Volcanology and Geothermal Research, 18: 57-115.

Bacon, C.R., and Druitt, T.H., 1988. Compositional evolution of the zoned calalkaline magma chamber of Mount Mazama, Crater Lake, Oregon. Contributions to mineralogy and petrology, $98: 224-256$.

Baldwin, E.M., 1981. Geology of Oregon. Third Edition; Kendal/Hunt Publishing Co., Dubuque, Iowa, $170 \mathrm{p}$.

Ballard, R.L., 1964. Distribution of beach sediment near the Columbia River. Department of Oceanography Technical Report No. 98, University of Washington, Seattle Washington, $82 \mathrm{p}$.

Beeson, M.H., and Moran, M.R., 1979. Columbia River Basalt Group stratigraphy in western Oregon. Oregon Geology, $41: 11-14$. 
Beeson, M.H., Fecht, K.R., Reidel, S.P., and Tolan, T.L., 1985. Regional Correlations within the Frenchman Springs Member of the Columbia River Basalt Group: New insights into the middle Miocene tectonics of northwestern Oregon. oregon Geology, 47:87-96.

Beeson, M.H., Tolan, T.L., and Anderson, J.L., 1989a. The Columbia River Basalt Group in western Oregon; geologic structures and other factors that controlled flow emplacement patterns, in Reidel, S.P., and Hooper, P.R., eds., Volcanism and tectonics in the Columbia River flood-basalt province: Geological Society of America Special Paper 239, p. 223-246.

Beeson, M.H., Tolan, T.L., and Madin, I.P., 1991. Geologic map of the Portland quadrangle, Multnomah, and Washington Counties, Oregon, and Clark, County, Washington. Oregon Department of Geology and Mineral Industries geologic Map Series GMS -75 .

Bloom, A.L., 1983. Sea level and coastal changes. In "LateQuaternary Environments of the United States, " v.2, "The Late Pleistocene", p. 42-51. University of Minnesota Press, Minneapolis.

Bretz, J.H., 1928. Alternative hypothesis for Channeled Scabland. Journal of Geology, 36:193-223.

Bretz, J.H., 1969. The Lake Missoula floods and the Channeled Scabland. Journal of Geology, 77:505-543.

Chelton, D.B. and Davis, R.E., 1982. Monthly mean sea-level variability along the west coast of North America. Journal of Physical Oceanography, 12:757-784.

Crandell, D.R., and Mullineaux, D.R., 1973. Pine Creek volcanic assemblage of Mount St. Helens, Washington. U.S. Geological Survey Bulletin 1383-A.

Crandell, D.R., and Mullineaux, D.R., 1978. Potential hazards from future eruptions of Mount st. Helens volcano,

Washington. U.S. Geological Survey Bulletin 1383-c, 26p.

Darienzo, M.E., and Peterson, C.D., 1990. Episodic tectonic subsidence of late Holocene salt marshes, northern Oregon central Cascadia margin. Tectonics, 9:122 .

Dudas, M.J., Howard, M.E., and Schmitt, R.A., 1973. Identification of dacitic tephra by activation analysis of their primary mineral phenocrysts. Quaternary Research, 3:307-315. 
Fairchild, L.H., and Wigmosta, M., 1983. Dynamic and volumetric characteristics of the May 18, 1980, lahars on the Toutle River Washington. In: Technical memo of PWRI no. 1908, Proceedings of symposium on erosion control in volcanic areas, July 6-9, 1982, Seattle and Vancouver, Washington. February 1983, Sabo (Erosion Control) division, Erosion Control Department, Public Works Research Institute, Ministry of Construction, Government of Japan.

Frank, F.J., 1970. Ground Water resources of the Clatsop Plains sand-dune area, Clatsop County, Oregon. U.S. Geological Survey Water Supply Paper 1899-A.

Fryxell, R., 1965. Mazama and Glacier Peak volcanic ash layers: relative ages. Science, 147: 1288-1290.

Glenn, J.L., 1965. Late Quaternary sedimentation and geologic history of north Willamette Valley, Oregon. Ph.D.

dissertation, Oregon State University, Corvallis Oregon.

Glenn, J.L., 1978. Sediment sources and Holocene sedimentation history in Tillamook Bay, Oregon. U.S. Geological Survey Water Resources Division Open file Report 78-680, 64 p.

Hamilton, P. 1983. Numeric modelling of the depth dependent salinity intrusion for the coal port deepening project in the Columbia River estuary. Final Report to the U.S. Army Corps of Engineers District, Portland, Oregon.

Hamilton, P. 1984. Hydrodynamic modelling of the Columbia River estuary, vol. 2. Final report of the Simulation Work Unit. Columbia River Data Development Program, Astoria, Oregon, 372pp.

Hamilton, P. 1990. Modeling of the salinity and circulation for the Columbia River estuary. Progress in Oceanography, $25: 113-156$.

Hammond, P.E, 1975. Some radiocarbon dates in surficial deposits of Bulletin No. $60,45 \mathrm{p}$. the Portland area. The ore Bin, 37:10:161-162.

Haushild, W.L., Perkins, R.W., Stevens, H.H.Jr., Dempster, G.R.Jr., and Glenn, J.L., 1966. Radionuclide transport in the Pasco to Vancouver, Washington, reach of the Columbia River, July 1962 to September 1963, Progress Report. US Geological Survey, Open File Report, Portland, Oregon, $188 \mathrm{pp}$. 
Herrmann, F.A., 1968. Model studies of navigation improvements, Columbia River estuary report 1: Hydraulic and salinity verification. U.S. Army Engineers Waterways Experiment station technical report, 2-735, Vicksburg, Mississippi, 24pp. 15 photos, 218 plates.

Hicks, S.D., 1972. On the classification and trends of long period sea level series. Shore Beach, 20-23.

Hicks, S.D., 1978. An average geopotential sea level series for the United States. Journal of Geophysical Research, $83: 1377-1379$.

Hubbell, D.W., Glenn, J.L., and Stevens, H.H.Jr., 1971. Studies of sediment transport in the Columbia River Estuary. Proceedings 1971. Technical Conference on estuaries in the Pacific Northwest. Proc. Circ. 42, Engineering Experiment Station, Corvallis, Oregon, 190226 .

Jay, D.A., and Good, J.W., 1978. Columbia River estuary sediment and sediment transport. Columbia River estuary inventory of physical and biological resources, Columbia River estuary Taskforce, Astoria, Oregon. 208-1 to 20845 .

Jay, D.A., 1984. Columbia River estuary circulatory processes. Final Report. Columbia River Estuary Data Development Program, Astoria, Oregon. 170pp.

Jay, D.A., and Smith, J.D., 1990. Circulation, density structure, and neap-spring transitions in the Columbia River estuary. Progress in Oceanography, 25:81-112.

Judson, S., and Ritter, D.F., 1964. Rates of regional denudation in the United States. Journal of Geophysical Research, 69:3395-3401.

Lockett, J., and Kidby, A.A., 1961. Prototype measurements of the Columbia River estuary. Proceedings of the American Society of Civil Engineers, Journal of the Hydraulics Division, 87:57-83.

Lowry, W.D., and Baldwin, E.M., 1952. Late Cenozoic geology of the lower Columbia River valley, Oregon and Washington. Geological Society of America Bulletin, 63: 1-24.

Madin, I.P., 1990. Earthquake-hazard geology maps of the Portland metropolitan area: Oregon Department of Geology and Mineral Industries Open File Report 0-90-2, 21 p. 8 maps. 
Magill, J., and Cox, A., 1981. Post Oligocene tectonic rotation of the Oregon western Cascade Range and the Klammath Mountains. Geology, 9:127-131.

McAnally, W.H.Jr., Brogdon, N.J., and Stewart, J.P., 1983. Columbia River estuary hybrid models, Report 4; entrance channel tests. U.S. Army Corps of Engineers, hydraulics laboratory, Vicksburg, Mississippi. 37p. and plates.

Mehringer, P.J.Jr., Blinman, E., and Peterson, K.L., 1977. Pollen influx and volcanic ash. Science, 198: 257-261.

Mullineaux, D.R., Hyde, J.H., and Rubin, M., 1975. Widespread late glacial and postglacial tephra deposits from Mount Saint Helens volcano, Washington. U.S. Geological Survey Journal of Research, 3: 329-335.

Mullineaux, D.R., and Wilcox, R.E., Ebaugh, W.F., Fryxell, R., and Rubin, M., 1978. Age of the last major scabland flood of the Columbia plateau in eastern Washington. Quaternary Research, 10: 171-180.

Mullineaux, D.R., and Wilcox, R.E., 1980. Stratigraphic subdivision of airfall tephra from the climatic series of eruptions of Mount Mazama, Oregon. EOS Transactions of the American Geophysical Union, 61: 66.

Neim, A.R., and Neim, W. A., 1985. Geologic map of the Astoria basin, Clatsop and northernmost Tillamook counties, northwest Oregon. Oregon Department of Geology and Mineral Industries $O i l$ and Gas Investigations 14, 8 p., 2 plates, scale 1:100,000.

Niem, W.A., Niem, A.R., and Snavely, P.D., Jr., 1987. Geologic map of the Astoria Basin, Clatsop and northernmost Tillamook Counties, northwest Oregon, OGI-14, state of Oregon Department of Geology and Mineral Industries.

O'Brien, M.P., 1952. Salinity currents in estuaries. Transactions of the American Geophysical Union, 9:520522 .

O'Brien, M.P., 1971. Field and laboratory studies navigation channels of the Columbia River estuary. Hydraulic

engineering laboratory, University of California at Berkeley, Report HEL-24-4, 35p.

Peterson, C.D., Sheidegger, K., Komar, P., and Neim, W.A., 1984. Sediment composition and hydrography of six highgradient estuaries of the northwestern United States. Journal of Sedimentary Petrology, 54:86-97. 
Peterson, C.D., and Phipps, J.B., 1992. Holocene sedimentary framework of Grays Harbor basin, Washington, USA. Society for Sedimentary Geology Special Publication no. 48. p. $273-285$.

Porter, S.C., 1978. Glacier Peak tephra in the North Cascade Range, Washington; stratigraphy, distribution, and relationship to late-glacial events. Quaternary Research, v. 10, p. 30-41.

Powers, H.A., and Wilcox, R.E., 1964. Volcanic ash from Mount Mazama (Crater Lake) and from Glacier Peak. Science 144: $1334-1336$.

Randal, K., Goles,G.G., and Kittleman,L.R.,1971. Geochemical and petrological characterization of ash samples from Cascade Range volcanos: Quaternary Research, v. 1, p. $261-282$.

Rankin, D.K., 1983. Holocene geologic history of the Clatsop Plains foredune ridge complex: Unpublished M.S. Thesis, Portland State University, Portland, Oregon, $176 \mathrm{p}$.

Reckendorf, F.F., 1992. Geomorphology, stratigraphy, and soil interpretations, Willamette Valley, Oregon. Proceedings of the eighth international soil management workshop: utilization of soil survey information for sustainable land use. Soil Conservation Service; U.S. Dept. of Agriculture, p. 178-200.

Sarna-Wojcicki, A.M., Champion, D.E., and Davis, J.O., 1983. Holocene volcanism in the conterminous United States and the role of silicic volcanic ash layers in correlation of latest Pleistocene and Holocene deposits. In Wright, H.E., Jr., ed., Late Quaternary environments of the United States; Vol. 2, the Holocene: Minneapolis, University of Minnesota Press, p. 52-77.

Schlicker, H.G., Deacon, R.J., Beaulieu, J.D., and Olcott, G.W., 1972. Environmental geology of the coastal region of Tillamook and Clatsop counties, Oregon. Oregon Department of Geology and Mineral Industries Bulletin 74, $164 \mathrm{p}$.

Schuster, R.I., 1981. Effects of the eruption of civil works and operations in the Pacific Northwest. In: The 1980 Eruptions of Mt. St. Helens, Washington, P.W. Lipman and D.R. Mullineaux, editors, U.S. Geological Survey Professional Paper 1250, Washington D.C. 
Sheidegger, K.F., Klum, L.D., and Runge, E.J., 1971. Sediment sources and dispersal patterns of Oregon continental shelf sands. Journal of Sedimentary Petrology, 41, 11121120 .

Sherwood, C.R., Creager, J.S., Roy, E.H., Gelfenbaum, G., and Dempsey, T., 1984. Sedimentary processes and environments in the Columbia River Estuary. Columbia River Estuary Data Development Program, Columbia River Estuary Study Taskforce, Astoria, Oregon. 317pp.

Sherwood, C.R., and Creager, J.S., 1990. Sedimentary Geology of the Columbia River estuary. Progress in Oceanography, $25: 15-79$.

Sherwood, C.R., Jay, D.A., Harvey, R.B., Hamilton, P. and Simenstad, C.A., 1990. Historical changes in the Columbia River Estuary. Progress in Oceanography, 25:299-352.

Simenstad, C.A., Small, L.F., McIntire, C.D., Jay, D.A. and Sherwood, C.R., 1990. An introduction to the Columbia River estuary: Brief history, prior studies and the role of the CREDDP studies. Progress in Oceanography, 25:175210 .

Simpson, R.W., and Cox, A., 1977. Paleomagnetic evidence for tectonic rotation of the Oregon Coast Range. Geology, $5: 585-589$.

Snavely, P.D.,Jr. 1948. Coquille Formation in the Nestucca Bay quadrangle. Oregon. Geological Society of the Oregon Country Newsletter, v. 14 p. 10-12.

Soil Survey of Clackamas County Area Oregon, 1985. U.S. Dept. of Agriculture; Soil Conservation Service, p. 183-184.

Soil Survey of Lane County Area Oregon, 1987. U.S. Dept. of Agriculture; Soil Conservation Service, p. 228.

Soil Survey of Linn County Area Oregon, 1987. U.S. Dept. of Agriculture; Soil Conservation Service, p. 227.

Swanson, R.D., 1986. A stratigraphic-geochemical study of the Troutdale Formation and Sandy River Mudstone in the Portland Basin and Lower Columbia River Gorge: Portland Oreg., Portland State University master's thesis, 103p.

Tolan, T.L., and Beeson, M H., 1984. Intracanyon flows of the Columbia River Basalt Group in the lower Columbia River Gorge and their relationship to the Troutdale Formation. Geological Society of America Bulletin, v. 95, no. 4, p. 463-477. 
Trimble, D.E., 1963. Geology of the Portland Oregon and adjacent areas: U.S. Geological Survey Bulletin 1119, $119 \mathrm{p}$.

U.S. Army, Corps of Engineers, 1933. Mouth of the Columbia River current survey 1932-1933. Report No. MCR 100/5.288. Portland, Oregon

U.S. Army, Corps of Engineers, 1960. 1959 current measurements program, Columbia River at the mouth, Oregon and Washington. v. 6, Corps of Engineers, Portland, Oregon. $320 \mathrm{p}$.

U.S. Geological Survey, 1988. Lithology, thickness, and extent of hydrogeologic units underlying the east Portland area, Oregon. Water Resources Investigations Report 88-4110.

Van Winkle, W., 1914a. Quality of the surface waters of Washington. US Geological Survey Water Supply Paper 339 , $105 \mathrm{pp}$.

Van Winkle, W., 1914b. Quality of the surface waters of Oregon. U.S. Geological Survey Water Supply Paper 363.

Waitt, R.B., Jr. 1985. Case for periodic jokulhaulps from Pleistocene glacial Lake Missoula: Geological Society of America Bulletin 96:10:p 1271-1286.

Wells, R.E., 1981. Geologic map of the Eastern Willapa Hills Cowlitz, Lewis, and Wahkiakum counties, Washington. State of Washington Department of Natural Resources, Open File Report 81-674.

Wells, R.E., and Heller, P.L., 1988. The relative contribution of accretion, shear, and extension to Cenozoic tectonic rotation in the Pacific Northwest. Geological Society of America Bulletin, v. 100, p. 325-338.

Whetten, J.T., 1966. Sediments from the lower Columbia River and Origin of Graywacke. Science, 152, 1057-1058.

Whetten, J.T., Kelly, J.C., and Hanson, L.G. 1969.

Characteristics of Columbia River sediment and sediment transport. Journal of Sedimentary Petrology, 39, 11491166 .

Williams, H., 1942. The geology of Crater Lake National Park, Oregon, with a reconnaissance of the cascade Range southward to Mount Shasta. Carnegie Institution of Washington Publication 540, $162 \mathrm{p}$. 
Wright, H.E., Jr., 1983. Late Quaternary environments of the United States. Vol. 2, The Holocene: Minneapolis, University of Minnesota Press, p. 52-77.

Yelin, T.S., and Patton, H.J., 1991. Seismotectonics of the Portland, Oregon, region. Seismological Society of America Bulletin, v. 81, no. 1 ; p.109-130. 
APPENDIX A

GEOCHEMICAL DATA AND ELEMENT CONCENTRATION PLOTS 
TABLE A-1 ELEMENT CONCENTRATIONS FOR TEPHRA SAMPLES (ALL VALUES ARE PPT EXCEPT WHERE NOTED) (Samples Analyzed by previous investigators)

Sample (Concentration / Uncertainty)

\begin{tabular}{|c|c|c|c|c|c|c|c|c|c|c|c|c|c|c|}
\hline \multirow[b]{2}{*}{$\begin{array}{l}\text { ASH } L-1 \\
\text { ASH } L-2 \\
\text { ASH } L-3 \\
\text { ASH } L-4 \\
\text { ASH } L-5 \\
\text { ASH } L-6 \\
\text { ASH } L-7 \\
\text { ASH } P-1 \\
\text { ASH } P-2 \\
\text { ASH } P-4 \\
\text { ASH } P-5 \\
\text { ASH } P-6 \\
\text { ASH } P-8 \\
\text { ASH } P-9 \\
\text { ASH } P-10 \\
\text { ASH } P-11 \\
\text { ASH } P-12 \\
\text { ASH } P-13\end{array}$} & \multicolumn{2}{|c|}{$\mathrm{Na} \%$} & \multicolumn{2}{|l|}{ La } & \multicolumn{2}{|c|}{ Sm } & \multicolumn{2}{|c|}{ Sc } & \multicolumn{2}{|c|}{$\mathrm{Ba}$} & \multicolumn{3}{|c|}{$\mathrm{Ce}$} & $\begin{array}{r}\text { Eu } \\
0.11\end{array}$ \\
\hline & $\begin{array}{l}3.55 \\
3.28 \\
3.61 \\
3.27 \\
3.22 \\
3.49 \\
3.23 \\
3.48 \\
3.61 \\
3.16 \\
3.26 \\
2.91 \\
3.57 \\
3.56 \\
3.13 \\
3.24 \\
3.53 \\
3.53\end{array}$ & $\begin{array}{l}0.06 \\
0.06 \\
0.06 \\
0.06 \\
0.06 \\
0.06 \\
0.06 \\
0.06 \\
0.06 \\
0.06 \\
0.06 \\
0.06 \\
0.08 \\
0.06 \\
0.06 \\
0.06 \\
0.06 \\
0.06\end{array}$ & $\begin{array}{l}26.2 \\
25.2 \\
22.3 \\
25.5 \\
24.0 \\
26.1 \\
23.3 \\
22.4 \\
22.3 \\
25.4 \\
24.1 \\
23.2 \\
23.5 \\
21.9 \\
21.3 \\
20.6 \\
21.9 \\
24.0\end{array}$ & $\begin{array}{l}1.4 \\
1.5 \\
1.4 \\
1.4 \\
1.3 \\
1.4 \\
1.4 \\
1.4 \\
1.3 \\
1.4 \\
1.4 \\
1.4 \\
1.4 \\
1.4 \\
1.4 \\
1.3 \\
1.4 \\
1.3\end{array}$ & $\begin{array}{l}5.17 \\
5.33 \\
4.93 \\
4.95 \\
4.75 \\
5.32 \\
5.02 \\
5.05 \\
4.85 \\
5.43 \\
4.82 \\
4.80 \\
5.04 \\
4.93 \\
4.95 \\
5.04 \\
4.86 \\
5.30\end{array}$ & $\begin{array}{l}0.10 \\
0.12 \\
0.11 \\
0.12 \\
0.11 \\
0.10 \\
0.10 \\
0.10 \\
0.10 \\
0.12 \\
0.12 \\
0.11 \\
0.12 \\
0.11 \\
0.11 \\
0.10 \\
0.11 \\
0.11\end{array}$ & $\begin{array}{r}7.66 \\
8.68 \\
7.15 \\
8.62 \\
7.46 \\
7.64 \\
8.22 \\
7.10 \\
6.98 \\
9.06 \\
8.88 \\
11.10 \\
7.61 \\
6.97 \\
9.71 \\
9.68 \\
6.93 \\
7.76\end{array}$ & $\begin{array}{l}0.17 \\
0.19 \\
0.16 \\
0.18 \\
0.16 \\
0.16 \\
0.17 \\
0.16 \\
0.15 \\
0.18 \\
0.18 \\
0.20 \\
0.16 \\
0.16 \\
0.18 \\
0.18 \\
0.16 \\
0.16\end{array}$ & $\begin{array}{r}1000 \\
1100 \\
1000 \\
1100 \\
1000 \\
1200 \\
900 \\
1100 \\
600 \\
1000 \\
700 \\
1100 \\
1200 \\
1300 \\
1200 \\
700 \\
900 \\
900\end{array}$ & $\begin{array}{l}400 \\
400 \\
400 \\
400 \\
400 \\
400 \\
400 \\
400 \\
400 \\
400 \\
400 \\
400 \\
400 \\
400 \\
400 \\
400 \\
400 \\
400\end{array}$ & $\begin{array}{l}45.0 \\
55.0 \\
38.0 \\
41.0 \\
49.0 \\
45.0 \\
45.0 \\
45.0 \\
35.0 \\
52.0 \\
44.0 \\
48.0 \\
41.0 \\
44.0 \\
43.0 \\
39.0 \\
45.0 \\
42.0\end{array}$ & $\begin{array}{l}4.0 \\
4.0 \\
4.0 \\
4.0 \\
4.0 \\
4.0 \\
4.0 \\
4.0 \\
4.0 \\
4.0 \\
4.0 \\
5.0 \\
4.0 \\
4.0 \\
4.0 \\
4.0 \\
4.0 \\
4.0\end{array}$ & $\begin{array}{l}1.06 \\
1.03 \\
0.96 \\
1.27 \\
0.96 \\
1.21 \\
1.16 \\
0.97 \\
0.96 \\
1.05 \\
1.02 \\
1.30 \\
1.13 \\
1.16 \\
1.05 \\
1.11 \\
1.17 \\
1.06\end{array}$ & $\begin{array}{l}0.11 \\
0.11 \\
0.11 \\
0.12 \\
0.11 \\
0.11 \\
0.11 \\
0.10 \\
0.10 \\
0.11 \\
0.11 \\
0.12 \\
0.11 \\
0.11 \\
0.11 \\
0.11 \\
0.11 \\
0.11\end{array}$ \\
\hline $\begin{array}{l}\text { STH JB } \\
\text { STH JY } \\
\text { STH } 4 \\
\text { STH } 3 \\
\text { STH UG } \\
\text { STH LG } \\
\text { STH UGG }\end{array}$ & $\begin{array}{l}1.94 \\
2.89 \\
3.36 \\
3.14 \\
3.25 \\
3.19 \\
3.16\end{array}$ & $\begin{array}{l}0.04 \\
0.06 \\
0.06 \\
0.06 \\
0.06 \\
0.06 \\
0.07\end{array}$ & $\begin{array}{r}9.9 \\
9.5 \\
11.7 \\
13.3 \\
13.4 \\
14.8 \\
17.5\end{array}$ & $\begin{array}{l}1.0 \\
1.1 \\
1.2 \\
1.2 \\
1.2 \\
1.2 \\
1.4\end{array}$ & $\begin{array}{l}3.38 \\
2.98 \\
2.76 \\
3.56 \\
3.30 \\
3.47 \\
3.25\end{array}$ & $\begin{array}{l}0.09 \\
0.08 \\
0.08 \\
0.09 \\
0.10 \\
0.11 \\
0.10\end{array}$ & $\begin{array}{r}12.50 \\
8.39 \\
7.49 \\
7.33 \\
13.30 \\
12.10 \\
8.14\end{array}$ & $\begin{array}{l}0.20 \\
0.18 \\
0.16 \\
0.16 \\
0.20 \\
0.20 \\
0.19\end{array}$ & $\begin{array}{r}700 \\
400 \\
800 \\
700 \\
600 \\
1100 \\
800\end{array}$ & $\begin{array}{l}400 \\
300 \\
300 \\
300 \\
400 \\
400 \\
400\end{array}$ & $\begin{array}{l}23.0 \\
24.0 \\
20.0 \\
27.0 \\
31.0 \\
34.0 \\
28.0\end{array}$ & $\begin{array}{l}4.0 \\
4.0 \\
4.0 \\
4.0 \\
4.0 \\
4.0 \\
5.0\end{array}$ & & $\begin{array}{l}0.11 \\
0.09 \\
0.09 \\
0.10 \\
0.11 \\
0.11 \\
0.12\end{array}$ \\
\hline $\begin{array}{l}\text { BCR-1-3 } \\
\text { BCR-1-4 } \\
0-16-1 \\
0-16-2 \\
\text { GSP-1-1 } \\
\text { GSP-1-2 }\end{array}$ & $\begin{array}{l}2.43 \\
2.46 \\
3.20 \\
3.19 \\
2.16 \\
2.26\end{array}$ & $\begin{array}{l}0.03 \\
0.04 \\
0.04 \\
0.05 \\
0.03 \\
0.05\end{array}$ & $\begin{array}{l}26.1 \\
27.3 \\
41.5 \\
40.1 \\
191.0 \\
188.0\end{array}$ & $\begin{array}{l}0.6 \\
0.9 \\
0.8 \\
1.1 \\
1.7 \\
2.0\end{array}$ & $\begin{array}{l}6.60 \\
6.69 \\
6.60 \\
6.62 \\
28.10 \\
27.40\end{array}$ & $\begin{array}{l}0.07 \\
0.10 \\
0.07 \\
0.09 \\
0.20 \\
0.30\end{array}$ & $\begin{array}{l}3.84 \\
3.92\end{array}$ & & $\begin{array}{l}500 \\
340\end{array}$ & $\begin{array}{l}200 \\
160\end{array}$ & 60.0 & $\begin{array}{l}3.0 \\
2.0\end{array}$ & $\begin{array}{l}0.37 \\
0.27\end{array}$ & $\begin{array}{l}0.06 \\
0.04\end{array}$ \\
\hline $\begin{array}{l}\text { GSP - } 1 \\
\text { BCR - } 1-2 \\
0-16-3 \\
0-16-4\end{array}$ & & & & & & & $\begin{array}{r}6.36 \\
33.00 \\
4.04 \\
3.90\end{array}$ & $\begin{array}{l}0.11 \\
0.30 \\
0.11\end{array}$ & $\begin{array}{r}1300 \\
1300 \\
600 \\
330\end{array}$ & $\begin{array}{l}300 \\
400 \\
300 \\
120\end{array}$ & $\begin{array}{r}394.0 \\
59.0 \\
70.0 \\
0.0\end{array}$ & $\begin{array}{l}7.0 \\
4.0 \\
4.0 \\
0.0\end{array}$ & $\begin{array}{l}1.86 \\
1.94 \\
0.33 \\
0.35\end{array}$ & $\begin{array}{l}0.13 \\
0.14 \\
0.08 \\
0.07\end{array}$ \\
\hline $\begin{array}{l}P-16 \\
P-16 G \\
P-16-1.5 \\
K 104(P-12) \\
K 107(P-11)\end{array}$ & $\begin{array}{l}3.43 \\
3.35 \\
2.11 \\
3.87 \\
3.40\end{array}$ & $\begin{array}{l}0.05 \\
0.05 \\
0.03 \\
0.05 \\
0.05\end{array}$ & $\begin{array}{l}27.6 \\
27.3 \\
24.0 \\
26.7 \\
25.9\end{array}$ & $\begin{array}{l}1.6 \\
1.6 \\
1.3 \\
1.7 \\
1.7\end{array}$ & $\begin{array}{l}4.96 \\
5.01 \\
5.25 \\
5.09 \\
4.07\end{array}$ & $\begin{array}{l}0.09 \\
0.11 \\
0.09 \\
0.10 \\
0.10\end{array}$ & $\begin{array}{r}8.15 \\
7.00 \\
20.90 \\
6.52 \\
6.73\end{array}$ & $\begin{array}{l}0.17 \\
0.17 \\
0.30 \\
0.16 \\
0.16\end{array}$ & $\begin{array}{l}500 \\
500 \\
500 \\
800 \\
700\end{array}$ & $\begin{array}{l}300 \\
300 \\
400 \\
300 \\
300\end{array}$ & $\begin{array}{l}43.0 \\
46.0 \\
49.0 \\
42.0 \\
44.0\end{array}$ & $\begin{array}{l}3.0 \\
3.0 \\
4.0 \\
3.0 \\
3.0\end{array}$ & $\begin{array}{l}1.27 \\
1.18 \\
1.48 \\
1.13 \\
1.09\end{array}$ & $\begin{array}{l}0.10 \\
0.10 \\
0.12 \\
0.10 \\
0.10\end{array}$ \\
\hline $\begin{array}{l}\text { MAZ } 1 \\
\text { MAZ } 2 \\
\text { MAZ } 3 \\
\text { CFP-154 } \\
\text { CFP-AVE- } 1\end{array}$ & $\begin{array}{l}3.71 \\
3.39 \\
3.23 \\
5.27 \\
5.23\end{array}$ & $\begin{array}{l}0.05 \\
0.06 \\
0.05\end{array}$ & $\begin{array}{l}25.1 \\
32.0 \\
22.7 \\
23.0 \\
22.0\end{array}$ & $\begin{array}{l}1.4 \\
2.0 \\
1.7\end{array}$ & $\begin{array}{l}4.66 \\
4.79 \\
4.79 \\
5.00 \\
4.80\end{array}$ & $\begin{array}{l}0.08 \\
0.16 \\
0.11\end{array}$ & $\begin{array}{l}7.46 \\
6.80 \\
6.75 \\
6.7 \\
6.5\end{array}$ & $\begin{array}{l}0.15 \\
0.20 \\
0.06\end{array}$ & $\begin{array}{c}600 \\
600 \\
560 \\
76\end{array}$ & $\begin{array}{l}200 \\
400 \\
200 \\
6\end{array}$ & $\begin{array}{r}42.0 \\
47.0 \\
46.3 \\
44 . \\
43 .\end{array}$ & $\begin{array}{l}3.0 \\
4.0 \\
1.1\end{array}$ & $\begin{array}{l}1.16 \\
0.91 \\
1.06\end{array}$ & $\begin{array}{l}0.09 \\
0.12 \\
0.05 \\
95 \\
92\end{array}$ \\
\hline nelps Crk & & & 13.5 & 0.7 & 2.56 & 0.15 & 7.54 & 0.14 & 220 & 50 & 30.7 & 0.8 & 0.82 & 0.0 \\
\hline
\end{tabular}


TABLE A-1 (cont inued)
ELEMENT CONCENTRATIONS FOR TEPHRA SAMPLES (ALL VALUES ARE pPI EXCEPT WHERE NOTED) (Samples Analyzed by previous investigators)

\begin{tabular}{|c|c|c|c|c|c|c|c|c|c|c|}
\hline & Lu & & Th & & Hf & & Co & & $\mathrm{Fe} \%$ & \\
\hline $\begin{array}{l}\text { ASH } L-1 \\
\text { ASH } L-2 \\
\text { ASH } L-3 \\
\text { ASH } L-4 \\
\text { ASH } L-5 \\
\text { ASH } L-6 \\
\text { ASH } L-7\end{array}$ & $\begin{array}{l}0.18 \\
0.14 \\
0.16 \\
0.26 \\
0.22 \\
0.15 \\
0.21\end{array}$ & $\begin{array}{l}0.12 \\
0.12 \\
0.11 \\
0.13 \\
0.11 \\
0.11 \\
0.12\end{array}$ & $\begin{array}{l}5.3 \\
4.5 \\
4.2 \\
3.9 \\
5.6 \\
5.2 \\
5.3\end{array}$ & $\begin{array}{l}0.6 \\
0.7 \\
0.6 \\
0.6 \\
0.6 \\
0.6 \\
0.6\end{array}$ & $\begin{array}{l}5.1 \\
8.0 \\
6.6 \\
5.1 \\
7.3 \\
9.1 \\
6.3\end{array}$ & $\begin{array}{l}1.10 \\
1.20 \\
1.10 \\
1.10 \\
1.10 \\
1.10 \\
1.10\end{array}$ & $\begin{array}{r}7.60 \\
12.20 \\
6.70 \\
9.70 \\
7.50 \\
7.30 \\
9.40\end{array}$ & $\begin{array}{l}0.90 \\
1.20 \\
0.80 \\
1.10 \\
0.90 \\
0.80 \\
1.00\end{array}$ & $\begin{array}{l}2.03 \\
2.12 \\
1.84 \\
2.39 \\
1.94 \\
2.04 \\
2.40\end{array}$ & $\begin{array}{l}0.11 \\
0.11 \\
0.09 \\
0.11 \\
0.10 \\
0.10 \\
0.11\end{array}$ \\
\hline $\begin{array}{l}\text { ASH } P-1 \\
\text { ASH } P-2 \\
\text { ASH } P-4 \\
\text { ASH } P-5 \\
\text { ASH } P-6 \\
\text { ASH } P-8 \\
\text { ASH } P-9 \\
\text { ASH } P-10 \\
\text { ASH } P-11 \\
\text { ASH } P-12 \\
\text { ASH } P-13\end{array}$ & $\begin{array}{l}0.24 \\
0.21 \\
0.15 \\
0.36 \\
0.27 \\
0.34 \\
0.28 \\
0.31 \\
0.25 \\
0.16 \\
0.15\end{array}$ & $\begin{array}{l}0.11 \\
0.11 \\
0.12 \\
0.14 \\
0.14 \\
0.13 \\
0.13 \\
0.14 \\
0.13 \\
0.12 \\
0.12\end{array}$ & $\begin{array}{l}5.6 \\
4.7 \\
4.6 \\
5.9 \\
5.0 \\
5.2 \\
5.3 \\
4.1 \\
4.3 \\
4.6 \\
6.0\end{array}$ & $\begin{array}{l}0.6 \\
0.6 \\
0.7 \\
0.6 \\
0.7 \\
0.6 \\
0.6 \\
0.7 \\
0.6 \\
0.6 \\
0.6\end{array}$ & $\begin{array}{l}6.3 \\
6.3 \\
4.7 \\
7.8 \\
6.0 \\
5.6 \\
7.0 \\
7.4 \\
7.4 \\
7.5 \\
5.9\end{array}$ & $\begin{array}{l}1.00 \\
1.00 \\
1.10 \\
1.10 \\
1.30 \\
1.10 \\
1.10 \\
1.20 \\
1.10 \\
1.10 \\
1.10\end{array}$ & $\begin{array}{r}7.30 \\
5.40 \\
10.50 \\
9.00 \\
14.70 \\
7.40 \\
6.60 \\
11.30 \\
12.50 \\
6.00 \\
8.80\end{array}$ & $\begin{array}{l}0.90 \\
0.70 \\
1.10 \\
1.00 \\
1.40 \\
0.90 \\
0.80 \\
1.20 \\
1.10 \\
0.80 \\
0.90\end{array}$ & $\begin{array}{l}1.71 \\
1.88 \\
2.51 \\
2.14 \\
2.87 \\
2.04 \\
2.05 \\
2.77 \\
2.56 \\
1.89 \\
1.89\end{array}$ & $\begin{array}{l}0.09 \\
0.09 \\
0.11 \\
0.10 \\
0.13 \\
0.10 \\
0.10 \\
0.12 \\
0.11 \\
0.09 \\
0.10\end{array}$ \\
\hline $\begin{array}{ll}\text { STH JB } \\
\text { STH JY } \\
\text { STH } 4 \\
\text { STH } 3 \\
\text { STH UG } \\
\text { STH LG } \\
\text { STH UGG }\end{array}$ & $\begin{array}{l}0.24 \\
0.20 \\
0.20 \\
0.22 \\
0.22 \\
0.06 \\
0.12\end{array}$ & $\begin{array}{l}0.14 \\
0.12 \\
0.12 \\
0.12 \\
0.14 \\
0.14 \\
0.14\end{array}$ & $\begin{array}{l}1.8 \\
2.5 \\
2.5 \\
2.7 \\
0.7 \\
1.4 \\
1.9\end{array}$ & $\begin{array}{l}0.7 \\
0.6 \\
0.6 \\
0.6 \\
0.7 \\
0.7 \\
0.7\end{array}$ & $\begin{array}{l}4.3 \\
4.7 \\
4.9 \\
5.1 \\
3.4 \\
4.3 \\
3.2\end{array}$ & $\begin{array}{l}1.20 \\
1.10 \\
1.00 \\
1.00 \\
1.20 \\
1.20 \\
1.20\end{array}$ & $\begin{array}{l}19.40 \\
11.30 \\
10.70 \\
11.00 \\
20.80 \\
22.40 \\
12.80\end{array}$ & $\begin{array}{l}1.40 \\
1.20 \\
1.00 \\
1.10 \\
1.50 \\
1.50 \\
1.20\end{array}$ & $\begin{array}{l}4.68 \\
3.10 \\
2.72 \\
2.68 \\
4.13 \\
3.95 \\
2.99\end{array}$ & $\begin{array}{l}0.16 \\
0.13 \\
0.12 \\
0.12 \\
0.15 \\
0.15 \\
0.14\end{array}$ \\
\hline $\begin{array}{l}\text { BCR-1-3 } \\
\text { BCR-1-4 } \\
0-16-1 \\
0-16-2 \\
\text { GSP-1-1 } \\
\text { GSP-1-2 }\end{array}$ & $\begin{array}{l}0.39 \\
0.31\end{array}$ & $\begin{array}{l}0.11 \\
0.08\end{array}$ & $\begin{array}{r}10.2 \\
9.1\end{array}$ & $\begin{array}{l}0.4 \\
0.3\end{array}$ & $\begin{array}{l}9.4 \\
6.9\end{array}$ & $\begin{array}{l}0.80 \\
0.60\end{array}$ & $\begin{array}{l}2.30 \\
1.80\end{array}$ & $\begin{array}{l}0.40 \\
0.30\end{array}$ & $\begin{array}{l}1.12 \\
1.13\end{array}$ & $\begin{array}{l}0.05 \\
0.04\end{array}$ \\
\hline $\begin{array}{l}\text { GSP - 1 } \\
\text { BCR-1-2 } \\
0-16-3 \\
0-16-4\end{array}$ & $\begin{array}{l}0.09 \\
0.55 \\
0.39 \\
0.25\end{array}$ & $\begin{array}{l}0.09 \\
0.18 \\
0.13 \\
0.07\end{array}$ & $\begin{array}{r}104.0 \\
6.6 \\
8.8 \\
9.1\end{array}$ & $\begin{array}{l}1.3 \\
0.7 \\
0.6 \\
0.2\end{array}$ & $\begin{array}{r}15.9 \\
8.4 \\
7.9 \\
7.4\end{array}$ & $\begin{array}{l}1.20 \\
1.30 \\
1.00 \\
0.50\end{array}$ & $\begin{array}{r}10.60 \\
53.90 \\
2.10 \\
1.90\end{array}$ & $\begin{array}{l}0.90 \\
1.80 \\
0.60 \\
0.20\end{array}$ & $\begin{array}{l}3.04 \\
9.37 \\
1.15 \\
1.13\end{array}$ & $\begin{array}{l}0.09 \\
0.19 \\
0.08 \\
0.03\end{array}$ \\
\hline $\begin{array}{l}P-16 \\
P-16 G \\
P-16-1.5 \\
K 104(P-12) \\
K 107(P-11)\end{array}$ & $\begin{array}{l}0.55 \\
0.38 \\
0.49 \\
0.32 \\
0.34\end{array}$ & $\begin{array}{l}0.13 \\
0.12 \\
0.16 \\
0.12 \\
0.12\end{array}$ & $\begin{array}{l}5.7 \\
5.5 \\
4.3 \\
5.1 \\
6.3\end{array}$ & $\begin{array}{l}0.5 \\
0.6 \\
0.7 \\
0.5 \\
0.5\end{array}$ & $\begin{array}{l}7.2 \\
7.6 \\
3.1 \\
7.3 \\
6.4\end{array}$ & $\begin{array}{l}0.90 \\
0.90 \\
1.20 \\
0.90 \\
0.90\end{array}$ & $\begin{array}{r}7.70 \\
5.50 \\
24.40 \\
4.30 \\
4.00\end{array}$ & $\begin{array}{l}0.80 \\
0.80 \\
1.30 \\
0.60 \\
0.70\end{array}$ & $\begin{array}{l}1.99 \\
1.80 \\
5.27 \\
1.61 \\
1.77\end{array}$ & $\begin{array}{l}0.10 \\
0.10 \\
0.15 \\
0.09 \\
0.09\end{array}$ \\
\hline $\begin{array}{l}\text { MAZ } 1 \\
\text { MAZ } 2 \\
\text { MAZ } 3 \\
\text { CFP-154 } \\
\text { CFP-AVE-1 }\end{array}$ & $\begin{array}{l}0.49 \\
0.55 \\
0.41 \\
0.35 \\
0.34\end{array}$ & $\begin{array}{l}0.12 \\
0.16 \\
0.07\end{array}$ & $\begin{array}{l}4.9 \\
6.4 \\
5.6 \\
5.3 \\
5.1\end{array}$ & $\begin{array}{r}0.5 \\
0.7 \\
0.19\end{array}$ & $\begin{array}{l}6.1 \\
6.5 \\
7.0 \\
5.9 \\
5.7\end{array}$ & $\begin{array}{l}0.80 \\
1.20 \\
0.40\end{array}$ & $\begin{array}{l}4.70 \\
4.50 \\
3.90\end{array}$ & $\begin{array}{l}0.60 \\
0.80 \\
0.30\end{array}$ & $\begin{array}{l}2.20 \\
1.79 \\
1.87 \\
1.61 \\
1.66\end{array}$ & $\begin{array}{l}0.09 \\
0.12 \\
0.04\end{array}$ \\
\hline Phelps Crk & 0.20 & 0.03 & 5.6 & 0.13 & 3.1 & 0.09 & 9.80 & 0.20 & 2.29 & 0.02 \\
\hline
\end{tabular}


TABLE A-2 INAA ANALYSIS; IST \& 2ND COUNT DATA FOR SAMPLES ANALYZED FOR THIS STUDY

ELEMENT CONCENTRATIONS FOR ASTORIA AREA ASH SAMPLES - 1ST COUNT DATA

SAMPLE (Concentration / Uncertainty) (All concentrations in ppm except where noted)

\begin{tabular}{|c|c|c|c|c|c|c|c|c|c|c|c|c|c|c|}
\hline \multirow[b]{2}{*}{$\begin{array}{l}\text { NG-1 } \\
\text { NG-2 } \\
\text { NG-3 } \\
\text { NG-4 } \\
\text { NG-5 } \\
\text { NG-6 } \\
\text { NG-7 } \\
\text { NG-8 } \\
\text { NG-9 }\end{array}$} & \multicolumn{2}{|r|}{ As } & \multicolumn{2}{|r|}{$\mathrm{Ga}$} & \multicolumn{2}{|c|}{$\mathrm{Na} \%$} & \multicolumn{2}{|r|}{$K$} & \multicolumn{3}{|c|}{ Sc } & \multicolumn{2}{|l|}{$\mathrm{Cr}$} & $\mathrm{Fe} \%$ \\
\hline & $\begin{array}{r}16.35 \\
7.10 \\
5.87 \\
4.02 \\
7.19 \\
8.34 \\
3.28 \\
6.41 \\
12.39\end{array}$ & $\begin{array}{r}0.00 \\
9.57 \\
24.73 \\
25.41 \\
26.08 \\
25.66 \\
37.41 \\
24.37 \\
0.00\end{array}$ & $\begin{array}{r}11.13 \\
11.20 \\
29.96 \\
49.96 \\
16.20 \\
0.00 \\
32.24 \\
0.00 \\
181.36\end{array}$ & $\begin{array}{r}0.00 \\
22.75 \\
40.93 \\
0.00 \\
0.00 \\
0.00 \\
37.31 \\
0.00 \\
0.00\end{array}$ & $\begin{array}{l}3.35 \\
1.46 \\
3.27 \\
3.16 \\
3.40 \\
3.45 \\
3.25 \\
3.23 \\
3.05\end{array}$ & $\begin{array}{l}0.25 \\
0.22 \\
0.25 \\
0.26 \\
0.26 \\
0.30 \\
0.28 \\
0.30 \\
0.28\end{array}$ & $\begin{array}{l}2.03 \\
1.57 \\
2.65 \\
2.40 \\
2.22 \\
2.45 \\
2.93 \\
2.91 \\
2.41\end{array}$ & $\begin{array}{r}9.96 \\
5.79 \\
14.04 \\
14.57 \\
13.58 \\
0.00 \\
15.71 \\
14.87 \\
19.15\end{array}$ & $\begin{array}{r}7.79 \\
16.24 \\
7.87 \\
7.80 \\
8.66 \\
8.91 \\
8.36 \\
7.96 \\
7.21\end{array}$ & $\begin{array}{l}4.44 \\
2.65 \\
5.08 \\
6.23 \\
5.65 \\
6.56 \\
4.43 \\
5.52 \\
5.45\end{array}$ & $\begin{array}{r}134.83 \\
109.61 \\
0.00 \\
0.00 \\
0.00 \\
0.00 \\
0.00 \\
78.53 \\
0.00\end{array}$ & $\begin{array}{l}0.00 \\
0.00 \\
0.00 \\
0.00 \\
0.00 \\
0.00 \\
0.00 \\
0.00 \\
0.00\end{array}$ & $\begin{array}{l}2.41 \\
6.37 \\
3.56 \\
2.42 \\
2.10 \\
3.13 \\
2.51 \\
2.88 \\
2.81\end{array}$ & $\begin{array}{r}28.06 \\
16.58 \\
0.00 \\
19.15 \\
27.81 \\
24.89 \\
15.52 \\
0.00 \\
0.00\end{array}$ \\
\hline $\begin{array}{l}\text { MAG- } 1 \\
\text { JR-1 } \\
\text { JB-2 } \\
1633 a\end{array}$ & & & & & & & & & $\begin{array}{r}6.10 \\
3.84 \\
54.00\end{array}$ & $\begin{array}{l}1.27 \\
3.14 \\
0.53\end{array}$ & $\begin{array}{l}0.00 \\
0.00\end{array}$ & $\begin{array}{l}0.00 \\
0.00\end{array}$ & $\begin{array}{l}1.86 \\
4.22 \\
9.89\end{array}$ & $\begin{array}{l}5.10 \\
0.00 \\
3.08\end{array}$ \\
\hline $\begin{array}{l}\text { NG-4* } \\
\text { MAG-1* }\end{array}$ & $\begin{array}{l}23.40 \\
10.05\end{array}$ & $\begin{array}{l}0.00 \\
0.00\end{array}$ & & & $\begin{array}{l}3.04 \\
2.81\end{array}$ & $\begin{array}{l}0.38 \\
0.28\end{array}$ & $\begin{array}{l}2.74 \\
2.89\end{array}$ & $\begin{array}{r}21.69 \\
9.74\end{array}$ & $\begin{array}{r}8.03 \\
16.98\end{array}$ & $\begin{array}{l}6.05 \\
1.42\end{array}$ & $\begin{array}{l}0.00 \\
0.00\end{array}$ & $\begin{array}{l}0.00 \\
0.00\end{array}$ & $\begin{array}{l}2.20 \\
5.37\end{array}$ & $\begin{array}{l}0.0 \\
6.5\end{array}$ \\
\hline
\end{tabular}

$\begin{array}{llllllll}\text { Co } & \text { Sb } & \text { Hf } & \text { La } & \text { Sm } & \text { Yb } & \text { Lu } & \text { Th }\end{array}$

\begin{tabular}{|c|c|c|c|c|c|c|c|c|c|c|c|c|c|}
\hline $\begin{array}{l}\text { NG-1 } \\
\text { NG-2 } \\
\text { NG-3 } \\
\text { NG-4 } \\
\text { NG-5 } \\
\text { NG-6 } \\
\text { NG-7 } \\
\text { NG-8 } \\
\text { NG-9 }\end{array}$ & $\begin{array}{r}37.22 \\
28.89 \\
34.51 \\
12.02 \\
0.00 \\
3.12 \\
22.53 \\
17.08 \\
27.42\end{array}$ & $\begin{array}{r}0.0 \\
0.0 \\
0.0 \\
0.0 \\
0.0 \\
0.0 \\
49.5 \\
0.0 \\
0.0\end{array}$ & $\begin{array}{l}0.80 \\
0.81 \\
0.80 \\
0.61 \\
1.44 \\
7.13 \\
1.16 \\
0.92 \\
0.92\end{array}$ & $\begin{array}{r}34.46 \\
30.18 \\
37.85 \\
38.10 \\
27.80 \\
0.00 \\
49.04 \\
0.00 \\
0.00\end{array}$ & $\begin{array}{l}7.70 \\
6.67 \\
5.63 \\
6.15 \\
6.87 \\
7.90 \\
6.85 \\
7.68 \\
6.87\end{array}$ & $\begin{array}{r}0.00 \\
0.00 \\
0.00 \\
29.48 \\
0.00 \\
45.38 \\
39.93 \\
27.45 \\
42.98\end{array}$ & $\begin{array}{ll}25.18 & 3.32 \\
31.07 & 2.30 \\
23.68 & 5.11 \\
24.30 & 4.70 \\
24.36 & 6.02 \\
26.36 & 5.55 \\
25.00 & 4.21 \\
24.99 & 5.51 \\
21.63 & 4.26\end{array}$ & $\begin{array}{ll}4.54 & 1.78 \\
5.33 & 1.18 \\
5.11 & 1.78 \\
5.03 & 1.68 \\
5.27 & 1.54 \\
4.74 & 1.69 \\
5.35 & 1.55 \\
5.22 & 1.56 \\
4.13 & 1.76\end{array}$ & $\begin{array}{rr}3.07 & 26.72 \\
2.59 & 26.14 \\
2.62 & 0.00 \\
2.21 & 27.32 \\
7.16 & 0.00 \\
3.24 & 24.91 \\
4.52 & 23.11 \\
3.87 & 22.42 \\
2.91 & 31.73\end{array}$ & $\begin{array}{l}0.40 \\
0.34 \\
0.58 \\
0.30 \\
0.37 \\
0.30 \\
0.43 \\
0.44 \\
0.31\end{array}$ & $\begin{array}{r}33.38 \\
43.18 \\
20.99 \\
0.00 \\
37.28 \\
28.08 \\
0.00 \\
0.00 \\
0.00\end{array}$ & $\begin{array}{l}0.00 \\
16.24 \\
10.23 \\
15.39 \\
0.00 \\
14.74 \\
14.87 \\
16.71 \\
17.61\end{array}$ & $\begin{array}{l}0.0 \\
0.0 \\
0.0 \\
0.0 \\
0.0 \\
0.0 \\
0.0 \\
0.0 \\
0.0\end{array}$ \\
\hline $\begin{array}{l}\text { MAG-1 } \\
\text { JR-1 } \\
\text { JB-2 } \\
1633 \mathrm{a}\end{array}$ & $\begin{array}{l}11.37 \\
10.80 \\
39.80\end{array}$ & $\begin{array}{c}0.0 \\
0.0 \\
17.1\end{array}$ & & & $\begin{array}{l}1.56 \\
1.25\end{array}$ & $\begin{array}{l}44.74 \\
41.34\end{array}$ & $\begin{array}{ll}7.64 & 1.70 \\
3.66 & 2.89\end{array}$ & $\begin{array}{ll}0.00 & 0.00 \\
0.00 & 0.00\end{array}$ & & $\begin{array}{r}0.05 \\
5.08 \\
0 .\end{array}$ & $\begin{array}{r}0.00 \\
0.00 \\
00 \quad 0 .\end{array}$ & & $\begin{array}{l}0.0 \\
0.0\end{array}$ \\
\hline $\begin{array}{l}\text { IG-4* } \\
\text { IAG-1* }\end{array}$ & $\begin{array}{l}14.83 \\
20.59\end{array}$ & $\begin{array}{l}39.6 \\
10.4\end{array}$ & & & $\begin{array}{l}0.00 \\
6.53\end{array}$ & $\begin{array}{r}0.00 \\
39.43\end{array}$ & $\begin{array}{ll}26.83 & 4.53 \\
45.72 & 1.67\end{array}$ & $\begin{array}{ll}0.00 & 0.00 \\
0.00 & 0.00\end{array}$ & & $\begin{array}{l}1.15 \\
0.20\end{array}$ & $\begin{array}{l}0.00 \\
0.00\end{array}$ & $\begin{array}{r}6.50 \\
11.21\end{array}$ & $\begin{array}{l}0.0 \\
0.0\end{array}$ \\
\hline
\end{tabular}

* Repl icate analysis 
TABLE A-2 (continued) ASTORIA AREA ASH SAMPLES - 2ND COUNT DATA

SAMPLE CONCENTRATION (PPM) UNCERTAINTY (\%)

$\begin{array}{lllllll}\mathrm{Rb} & \mathrm{CS} & \mathrm{Sr} & \mathrm{Ba} & \mathrm{Sc} & \mathrm{Cr} & \mathrm{Fe} \%\end{array}$

NG-1

$N G-2$

NG-3

NG-4

NG-5

NG-6

NG-7

NG-8

NG-9

MAG-1

$\mathrm{JB}-2$

JR-1

$1633 a$

NG-4*

MAG-1*
82.0314 .40

77.3114 .97

64.6111 .18

61.2911 .40

51.6114 .24

61.1117 .26

52.6026 .13

77.8315 .59

53.9618 .29

$\begin{array}{lllllll}3.38 & 7.37 & 245.85 & 29.03 & 761.37 & 5.43\end{array}$ $\begin{array}{lllllll}5.59 & 8.96 & 657.87 & 0.00 & 579.83 & 7.19\end{array}$ $\begin{array}{llllll}3.46 & 8.82 & 229.26 & 24.95 & 781.05 & 5.10\end{array}$ $\begin{array}{llllll}3.77 & 11.10 & 231.95 & 25.63 & 689.36 & 5.41\end{array}$ $\begin{array}{lllllll}3.69 & 10.37 & 408.36 & 35.33 & 757.37 & 5.54\end{array}$ $\begin{array}{llllll}4.65 & 9.98 & 275.61 & 28.95 & 791.11 & 5.64\end{array}$ $\begin{array}{lllllll}3.82 & 8.03 & 0.00 & 0.00 & 741.19 & 6.26\end{array}$ $\begin{array}{llllll}4.12 & 9.89 & 271.18 & 23.35 & 728.70 & 5.98\end{array}$ $\begin{array}{llllll}3.84 & 10.74 & 231.41 & 23.01 & 626.10 & 6.75\end{array}$

$152.00 \quad 6.54$ 19.5733 .69 $257.00 \quad 2.55$

$\begin{array}{llllll}8.30 & 2.60 & 156.00 & 30.47 & 490.00 & 4.78\end{array}$ $\begin{array}{llllllll} & 2.91 & 31.92 & 492.65 & 0.00 & 208.03 & 10.48\end{array}$ $\begin{array}{llllllll}160.46 & 10.17 & 11.81 & 2.78 & 514.79 & 25.58 & 138.41 & 2.70\end{array}$

60.9415 .16

$3.11-7.44$

$149.41 \quad 4.87$

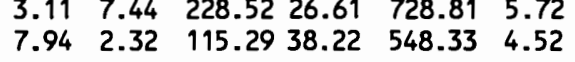

7.441 .01

$15.69 \quad 0.76$

$6.87 \quad 1.07$

$6.54 \quad 1.02$

7.331 .02

$\begin{array}{ll}7.87 & 0.67\end{array}$

$7.46 \quad 1.10$

7.191 .28

$6.05 \quad 1.13$

$\begin{array}{llll}17.00 & 0.39 & 105.00 & 1.64\end{array}$ $\begin{array}{llll}54.01 & 0.22 & 27.40 & 13.31\end{array}$

$\begin{array}{lllll}5.20 & 0.74 & 2.75 & 26.62\end{array}$

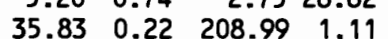

$\begin{array}{llll}6.48 & 1.07 & 6.99 & 27.20\end{array}$

$\begin{array}{llll}16.14 & 0.41 & 113.41 & 1.47\end{array}$
$2.06 \quad 1.52$

$4.03 \quad 0.96$

$1.91 \quad 1.51$

1.831 .48

$2.08 \quad 1.49$

$2.14 \quad 1.47$

$2.28 \quad 1.38$

$2.24 \quad 1.33$

$\begin{array}{ll}1.73 & 1.55\end{array}$

$\begin{array}{ll}4.86 & 0.51\end{array}$

9.890 .38

$0.62 \quad 2.46$

$9.21 \quad 0.37$

$\begin{array}{ll}1.86 & 1.39\end{array}$

$\begin{array}{ll}4.88 & 0.48\end{array}$
Co

$\begin{array}{llll}4.88 & 5.09 & 186.50 & 14.64\end{array}$

$\begin{array}{llll}14.84 & 2.93 & 98.41 & 34.51\end{array}$

$\begin{array}{lllll}4.31 & 4.46 & 69.88 & 27.87\end{array}$

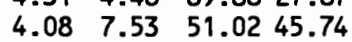

$\begin{array}{llll}5.00 & 6.51 & 57.22 & 44.84\end{array}$

$\begin{array}{llll}5.41 & 6.51 & 55.80 & 47.12\end{array}$

$\begin{array}{llll}4.62 & 5.32 & 0.00 & 0.00\end{array}$

$\begin{array}{lllll}4.53 & 4.48 & 0.00 & 0.00\end{array}$

$\begin{array}{llll}4.10 & 5.38 \quad 47.49 & 47.03\end{array}$

$N G-9$

MAG-1

JB-2

$\mathrm{JR}-1$

1633a

NG -4 *

MAG-1*
$20.00 \quad 1.48 \quad 126.00 \quad 16.29$

$\begin{array}{lllll}39.81 & 1.13 & 110.01 & 16.27\end{array}$

$0.84 \quad 12.63 \quad 15.76 \quad 34.68$

$38.56 \quad 1.01219 .08 \quad 13.16$

$4.02 \quad 5.19 \quad 52.51 \quad 44.50$

$\begin{array}{llll}19.53 \quad 1.37 & 121.78 \quad 16.01\end{array}$
$\mathrm{Ce}$

$\begin{array}{ll}49.58 & 2.43\end{array}$

$62.11 \quad 2.10$

$\begin{array}{ll}47.54 & 2.44\end{array}$

$45.62 \quad 2.50$

52.212 .36

$52.95 \quad 2.44$

51.612 .34

$48.96 \quad 2.40$
41.38

$41.38 \quad 2.65$

$94.00 \quad 0.94$ 7.9910 .68

$\begin{array}{ll}49.00 & 1.29\end{array}$

$\begin{array}{ll}178.15 & 0.67\end{array}$

$\begin{array}{ll}46.71 & 2.47\end{array}$

$93.65 \quad 0.94$
Nd

$25.15 \quad 0.00$ $0.00 \quad 0.00$

$27.25 \quad 0.00$

$23.27 \quad 0.00$

26.0434 .36

$\begin{array}{ll}30.13 \quad 0.00 & 0\end{array}$

27.1319 .17

$26.97 \quad 0.00$

25.5735 .54

44.0026 .58

25.5020 .62

$79.80 \quad 5.99$

24.8128 .84

$43.53 \quad 0.00$
Sm

$\begin{array}{ll}4.76 & 2.28\end{array}$

$\begin{array}{ll}5.63 & 1.29\end{array}$

$\begin{array}{ll}4.80 & 2.07\end{array}$

$4.40 \quad 2.26$

$\begin{array}{ll}4.94 & 2.21\end{array}$

$5.32 \quad 2.86$

$4.92 \quad 3.12$

4.813 .21

$4.20 \quad 3.32$

$78.00 \quad 0.64$

$2.30 \quad 1.47$

$6.20 \quad 1.07$

$16.72 \quad 0.56$

$4.44 \quad 3.35$

$7.87 \quad 1.41$
Eu

Tb

$1.15 \quad 5.50$

$1.50 \quad 4.56$

1.1010 .84

$1.02 \quad 6.71$

$1.18 \quad 10.23$

1.185 .06

1.1512 .66

$1.14 \quad 6.17$

$0.98 \quad 5.88$

$\begin{array}{lll}0.68 & 0.00\end{array}$

0.8116 .41

$0.61 \quad 10.27$

$0.55 \quad 10.11$

0.6211 .59

0.669 .97

$0.56 \quad 0.00$

0.620 .00

0.6427 .91

$0.88 \quad 0.00$

$\begin{array}{llll}0.31 & 8.19 & 1.10 & 4.48\end{array}$

$\begin{array}{llll}3.75 & 4.32 & 2.15 & 2.74\end{array}$

$\begin{array}{llll}1.09 & 9.51 & 0.54 & 9.39\end{array}$

$\begin{array}{llll}1.68 & 2.94 & 0.91 & 4.36\end{array}$
Tm

Yb

NG- 1

$N G-2$

NG-3

NG-4

NG- 5

NG-6

NG-7

NG-8

NG-9

MAG -1

JB-2

JR-1

$1633 a$

NG-4*

MAG-1* $\begin{array}{llll}0.00 & 0.00 & 2.90 & 11.90\end{array}$

$\begin{array}{llll}0.00 & 0.00 & 2.84 & 16.41\end{array}$

$\begin{array}{lllll}0.00 & 0.00 & 2.61 & 10.64\end{array}$

$\begin{array}{llll}0.00 & 0.00 & 2.86 & 13.97\end{array}$

$\begin{array}{lllll}0.00 & 0.00 & 3.24 & 10.32\end{array}$

$\begin{array}{llll}0.00 & 0.00 & 3.10 & 12.06\end{array}$

$\begin{array}{llll}0.00 & 0.00 & 3.03 & 11.37\end{array}$

$0.7035 .46 \quad 3.03 \quad 9.99$

$\begin{array}{llll}0.44 & 49.25 \quad 2.52 & 12.48\end{array}$

$\begin{array}{llll}0.52 & 37.22 \quad 3.00 \quad 9.28\end{array}$

$2.50 \quad 8.39$

$\begin{array}{llll}0.73 & 23.16 \quad 4.60 \quad 3.73\end{array}$

$\begin{array}{llll}1.25 & 19.85 & 8.01 & 5.11\end{array}$

$\begin{array}{llll}0.00 & 0.00 & 2.61 & 12.80\end{array}$

0.7124 .69

$3.12 \quad 8.24$

$\begin{array}{lrrr} & \text { Lu } & & \mathrm{Zr} \\ & & & \\ 0.38 & 7.16 & 241.79 & 23.90 \\ 0.40 & 12.44 & 498.31 & 43.42 \\ 0.37 & 7.02 & 206.20 & 22.65 \\ 0.34 & 6.46 & 274.81 & 37.93 \\ 0.39 & 6.55 & 210.90 & 43.62 \\ 0.39 & 8.29 & 402.52 & 41.49 \\ 0.39 & 7.31 & 198.54 & 41.90 \\ 0.36 & 8.18 & 0.00 & 0.00 \\ 0.33 & 7.97 & 184.91 & 0.00\end{array}$

Sb

Hf

Ta

$0.00 \quad 0.00$

$21.89 \quad 0.00$

0.7626 .98

$0.00 \quad 0.00$

$0.00 \quad 0.00$

$0.00 \quad 0.00$

$\begin{array}{ll}1.03 & 0.00\end{array}$

$0.00 \quad 0.00$

$0.00 \quad 0.00$

$0.40 \quad 10.35 \quad 92.34 \quad 47.70$

$\begin{array}{llll}0.40 & 9.93 \quad 50.88 & 0.00\end{array}$

$\begin{array}{lllll}0.68 & 4.17 & 102.00 & 22.05\end{array}$

$\begin{array}{llll}1.15 & 4.91 \quad 306.89 & 19.66\end{array}$

1.6523 .61
$6.22 \quad 0.00$

$5.65 \quad 4.21$

4.615 .50

$5.54 \quad 3.78$

$5.66 \quad 3.71$

$5.98 \quad 5.31$

$6.20 \quad 3.97$

$5.90 \quad 4.14$

5.694 .13

$4.98 \quad 4.23$

1.1217 .39

1.4917 .20

0.9916 .15

$0.94 \quad 0.00$

1.1912 .06

$0.68 \quad 0.00$

0.7521 .50

0.9420 .82

$0.78 \quad 0.00$

$00 \quad 1.6911 .66$

$\begin{array}{llllll}1.75 & 11.45 & 4.70 & 2.74 & 1.90 & 4.01\end{array}$

$\begin{array}{llllll}6.80 & 10.16 & 7.41 & 3.10 & 5.38 & 6.95\end{array}$

$\begin{array}{llll}0.36 & 7.66 & 197.75 & 22.52\end{array}$

$0.00 \quad 0.00$

$5.70 \quad 3.95$

0.9024 .23

$\begin{array}{llll}0.42 & 8.62 & 137.36 & 0.00\end{array}$

$\begin{array}{ll}1.32 & 0.00\end{array}$

3.773 .94

2.314 .00 
TABLE A-2 (continued) ASTORIA AREA ASH SAMPLES - 2ND COUNT DATA

Th La

$\begin{array}{lrrrr}\text { NG-1 } & 6.34 & 3.21 & 29.21 & 6.00 \\ \text { NG-2 } & 7.56 & 2.48 & 34.40 & 3.68 \\ \text { NG-3 } & 5.80 & 2.87 & 27.69 & 5.20 \\ \text { NG-4 } & 5.41 & 2.95 & 25.33 & 5.71 \\ \text { NG-5 } & 5.92 & 2.89 & 26.24 & 5.66 \\ \text { NG-6 } & 6.42 & 3.04 & 38.27 & 7.73 \\ \text { NG-7 } & 6.05 & 3.34 & 29.13 & 6.95 \\ \text { NG-8 } & 5.93 & 2.90 & 31.31 & 7.79 \\ \text { NG-9 } & 5.12 & 3.17 & 25.40 & 8.04 \\ & & & & \\ \text { MAG-1 } & 12.80 & 1.12 & 46.00 & 1.75 \\ \text { JB-2 } & 0.30 & 48.19 & 1.96 & 18.71 \\ \text { JR-1 } & 26.50 & 0.55 & 21.00 & 3.59 \\ \text { 1633a } & 25.49 & 0.68 & 89.36 & 1.96 \\ & & & & \\ \text { NG-4* } & 5.64 & 2.95 & 31.96 & 7.02 \\ \text { MAG-1* } & 12.77 & 0.99 & 53.74 & 4.31\end{array}$

* Replicate Analysis 
TABLE A-3 (continued) LOCATIONS FOR SAMPLES USED IN INAA ANALYSIS

MOUNT SAINT HELENS SAMPLES

STH-JB

STH-JY

STH -4

STH-3

STH-UG

STH-LG

STH-UGG

BCR $-1-2$

BCR-1-3

BCR $-1-4$

GSP - 1

GSP - 1- 1

GSP - 1-2

0-16-1

$0-16-2$

$0-16-3$

$0-16-4$

\author{
Upper of two discrete beds of set $J$ tephra \\ Main bed of set $J$ tephra, below JB \\ Upper most layer of set $S$ tephra \\ Lower of 2 main beds at top of set $S$ \\ Upper part of layer $G$ \\ Lower part of layer $G$ \\ Layer $\mathrm{G}$
}

USGS STANDARDS
Columbia River Basalt - 2nd replicate analysis
Columbia River Basalt - 3rd replicate analysis
Columbia River Basalt - 4 th replicate analys is
Quartz Monzonite
Quartz Monzonite - 2nd replicate analys is
Quartz Monzonite - 3rd repl icate analysis
Rhyol ite Obsidian
Rhyolite Obsidian - 2nd replicate analysis
Rhyolite Obsidian - 3rd replicate analys is
Rhyolite Obsidian - 4th replicate analysis 


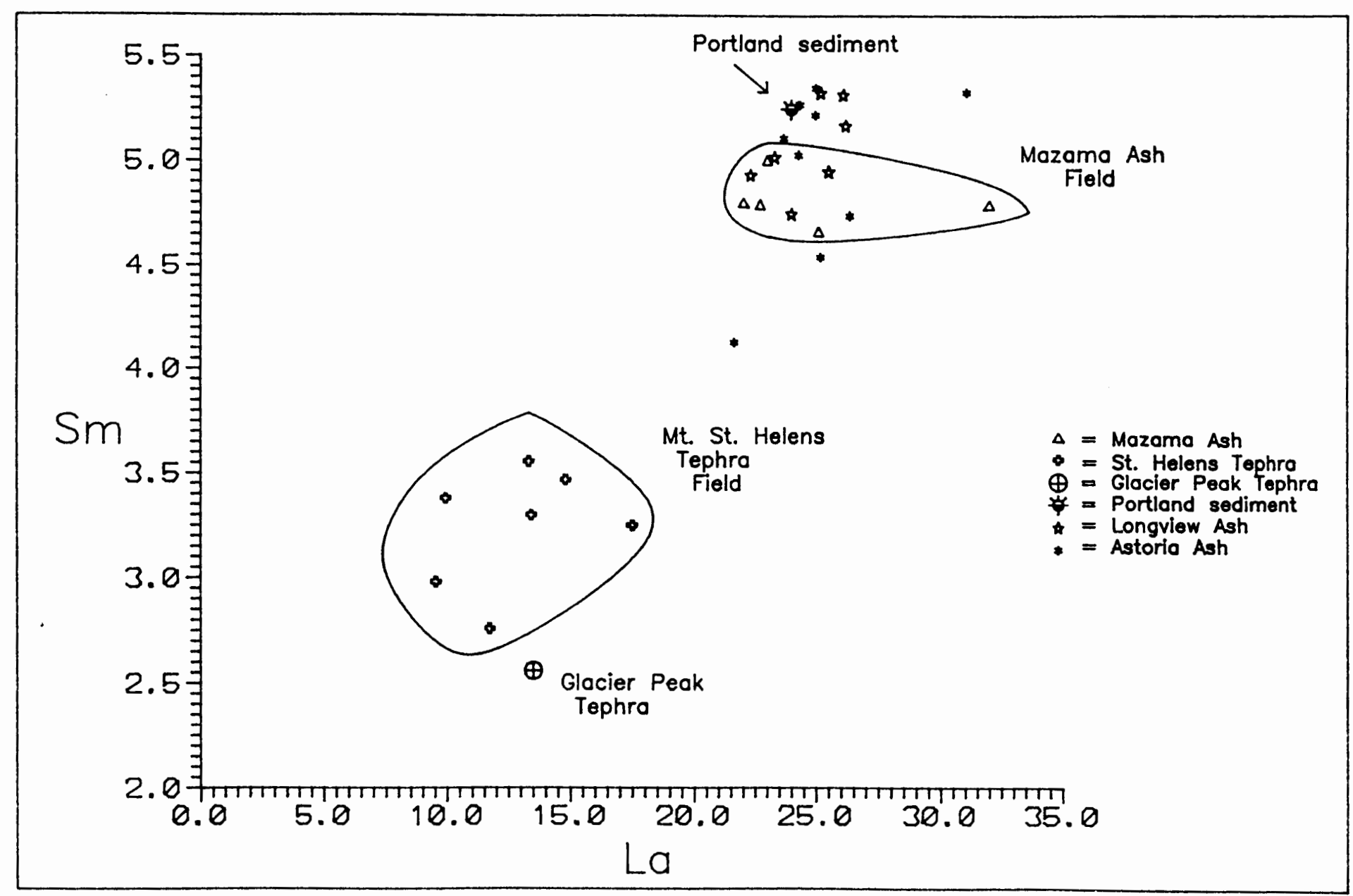

Figure A-1. Lanthanum vs. Somarium; Astorio and Longview oreo sample sites. 


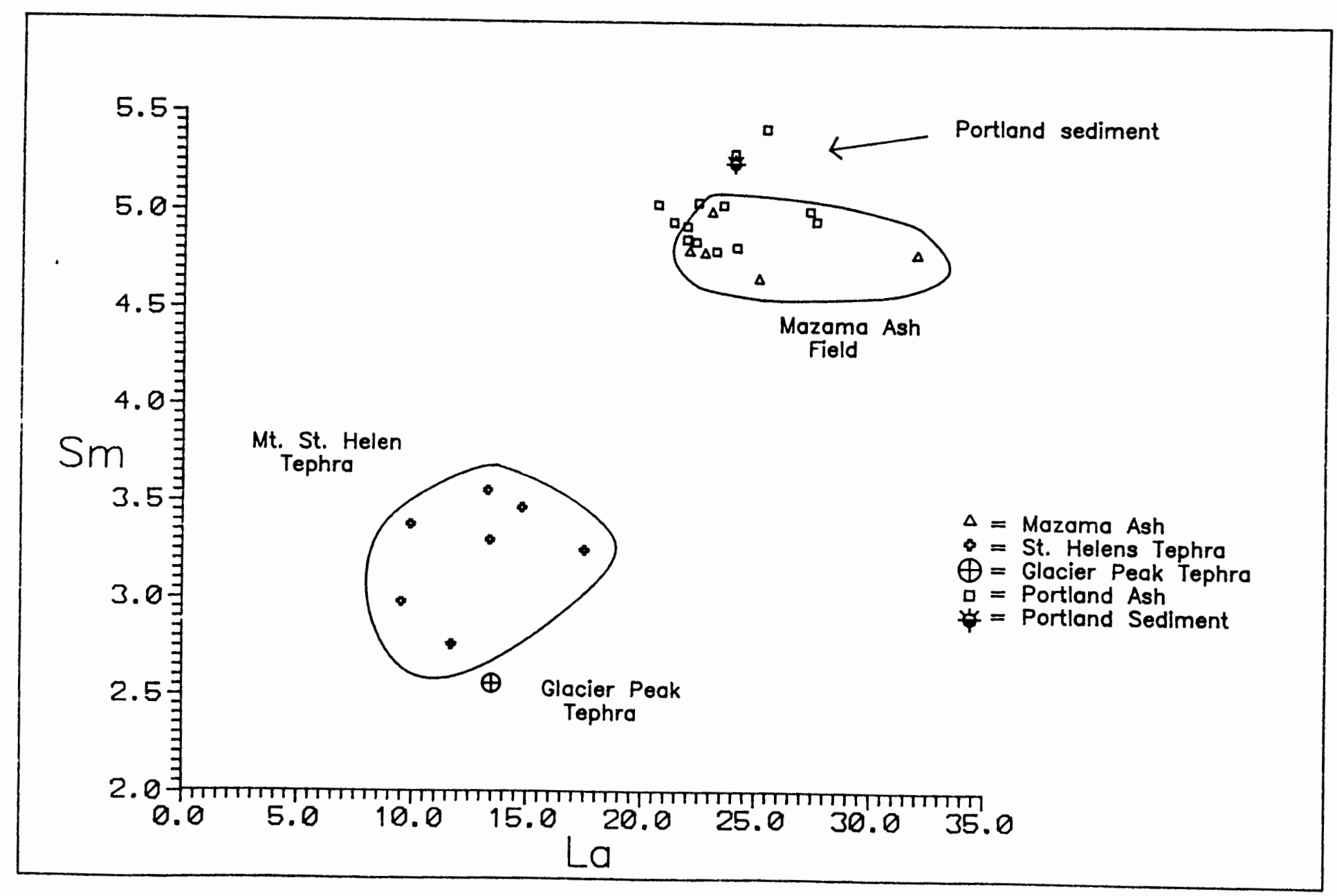

Eigure $A-2$ Lanthanum vs. Samarium; Portland area sample sites. 


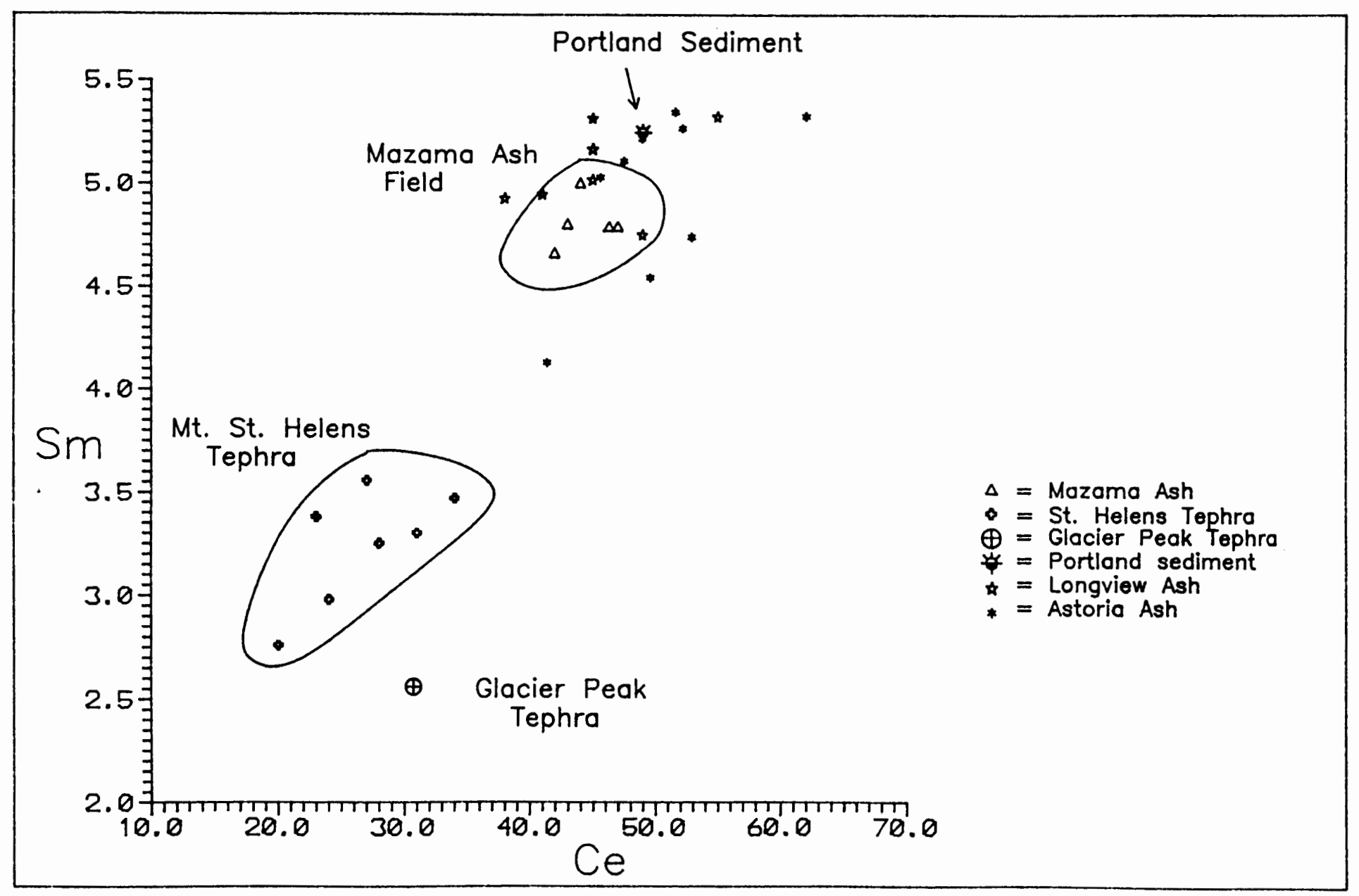

Eigure A-3. Cerium vs. Samorium; Longview and Astoria area sample sites. 


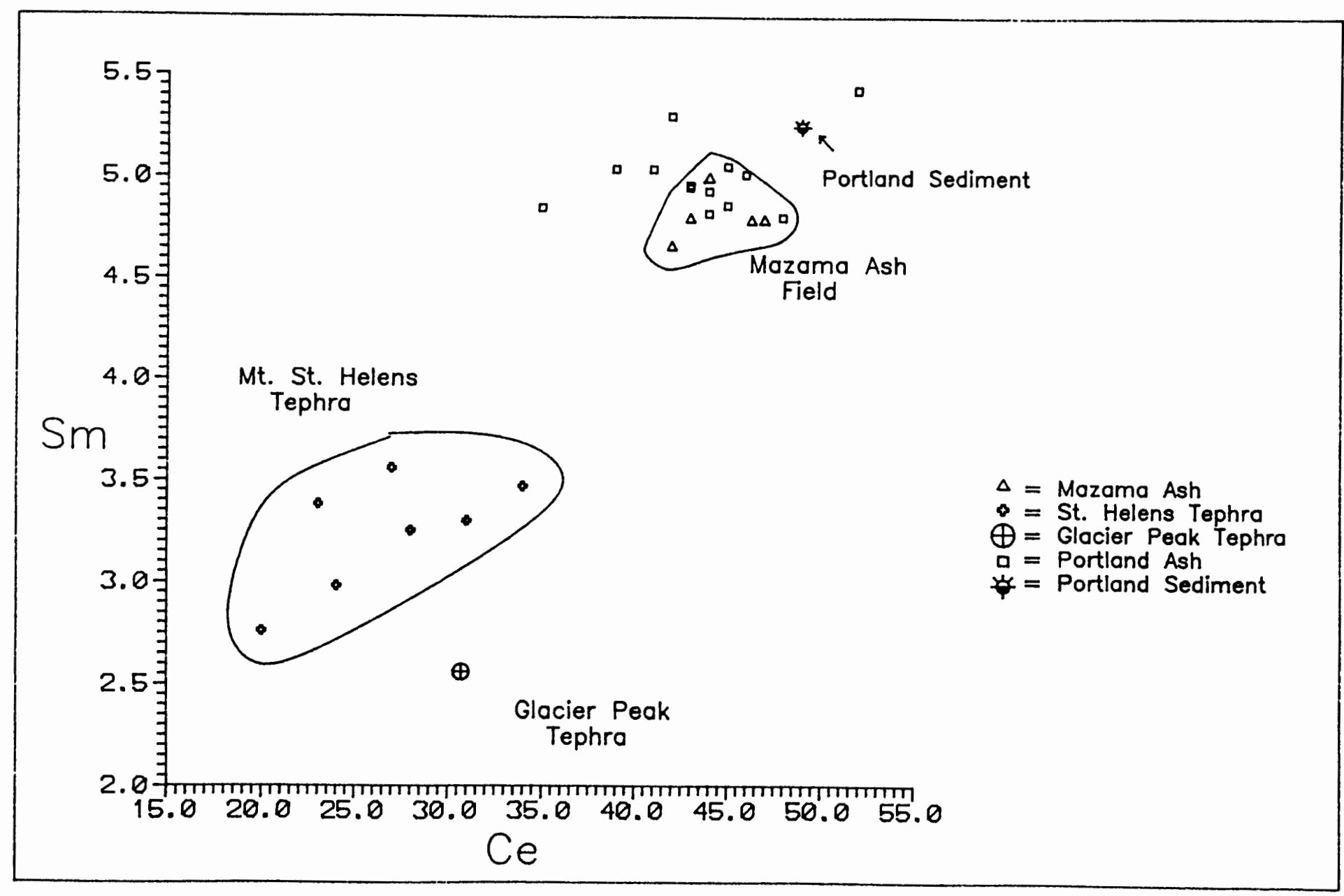

Eigure $\mathrm{A}-4 \quad$ Cerium vs. Somarium; Portland areo sample sites. 


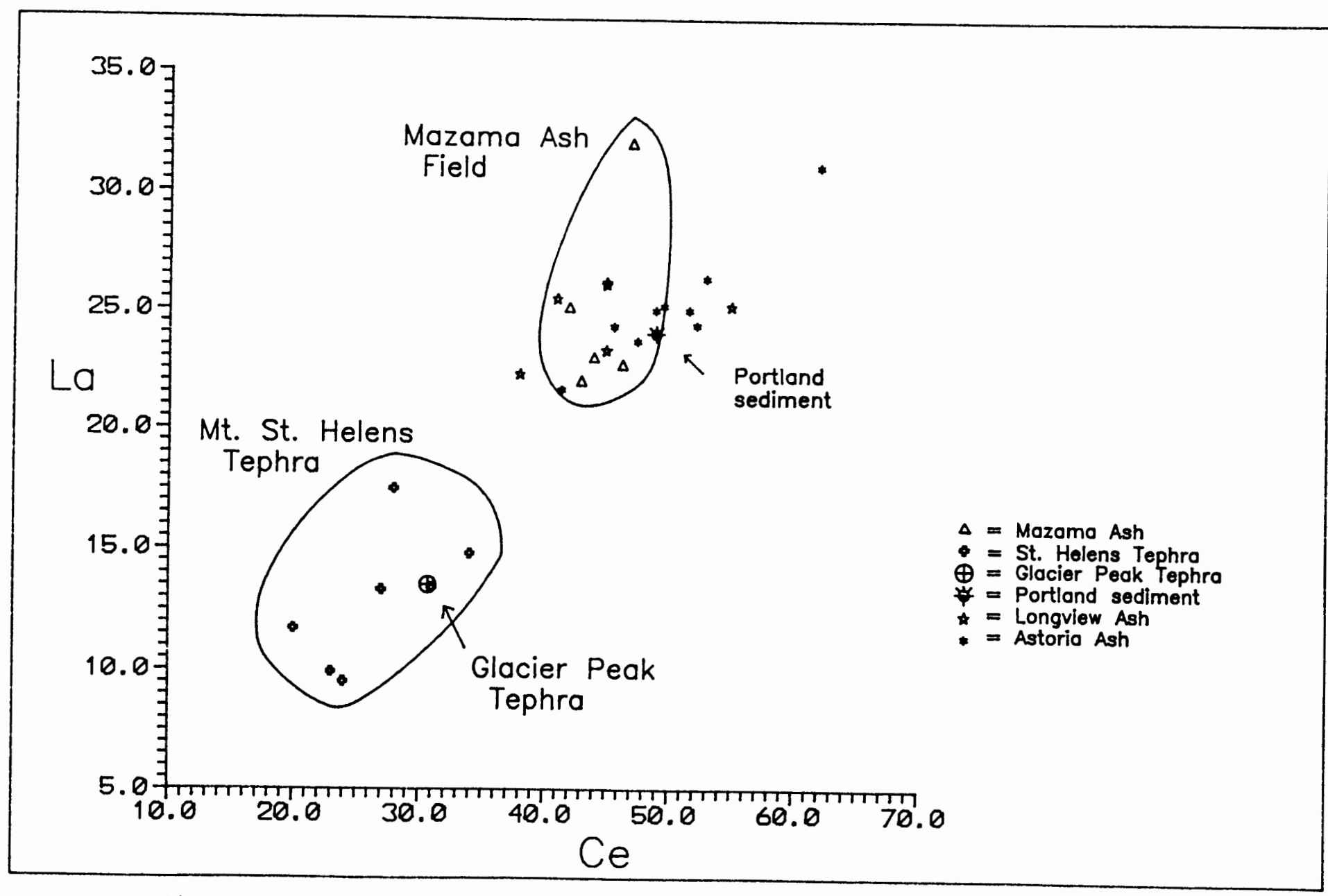

Figure A-5, Cerium vs. Lantanum; Longview and Astoria area sample sites. 


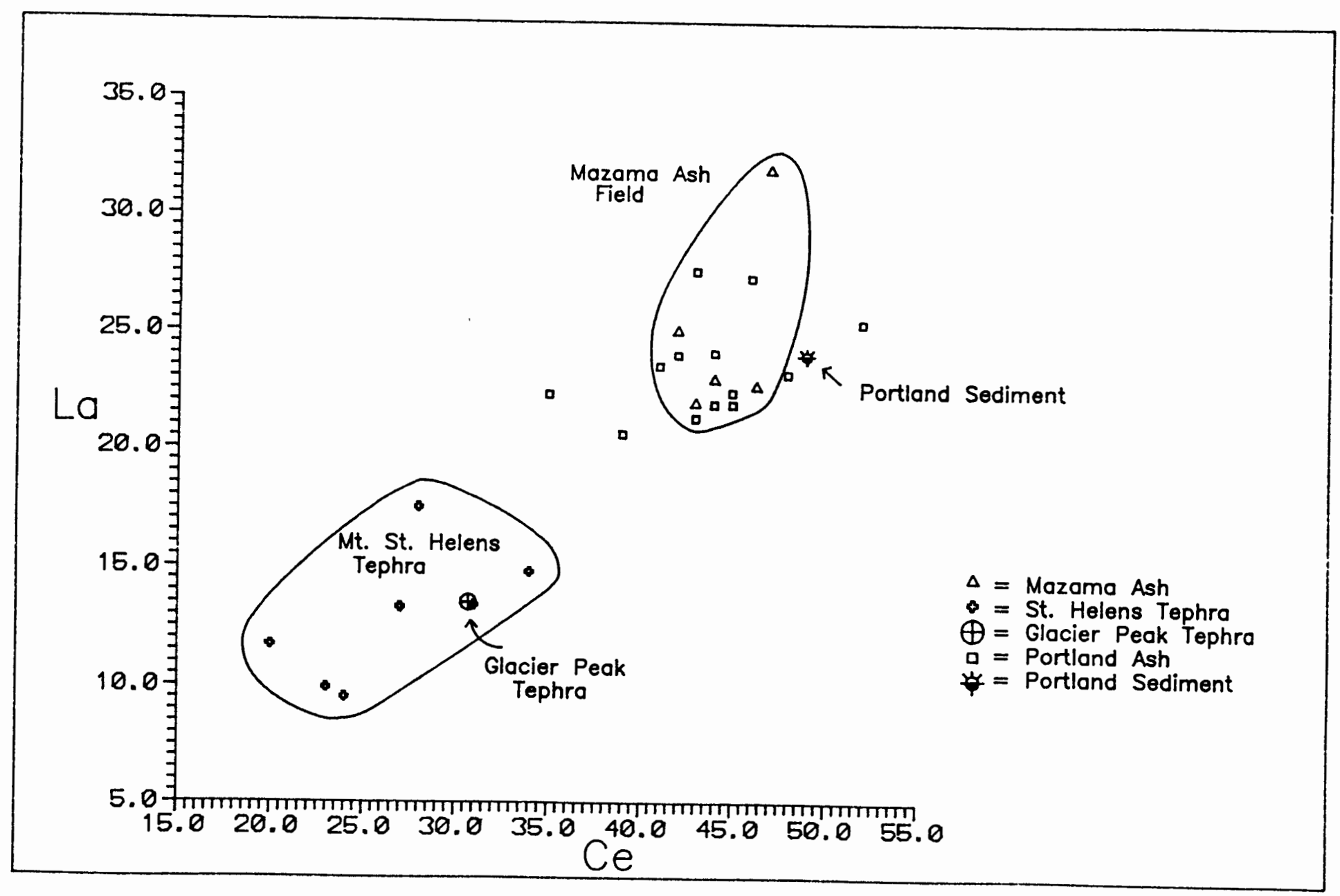

Eigure A-6, Cerium vs. Lantanum; Portland area sample sites. 


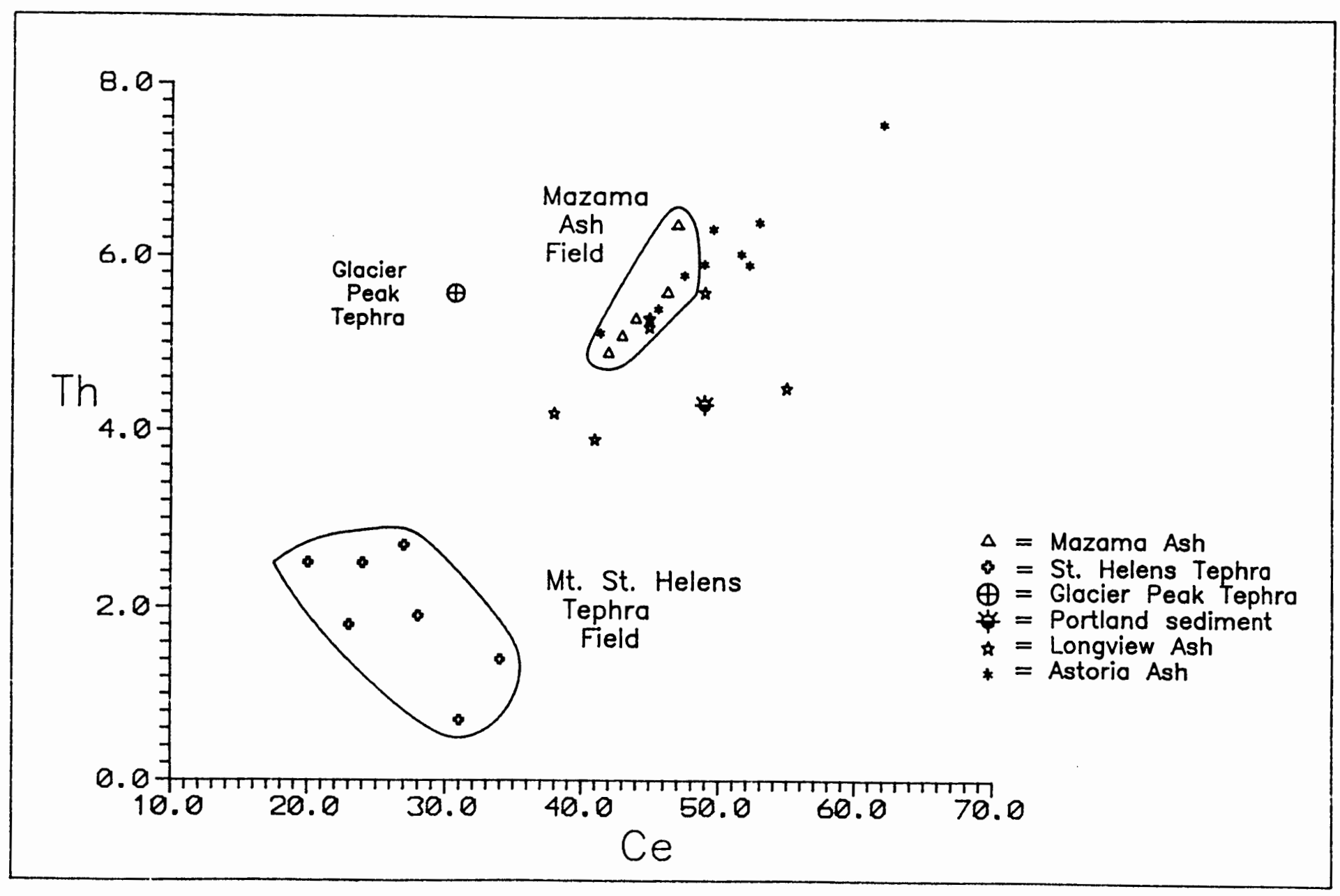

Eigure $A-Z$ Cerium vs. Thorium; Longview and Astoria area sample sites. 


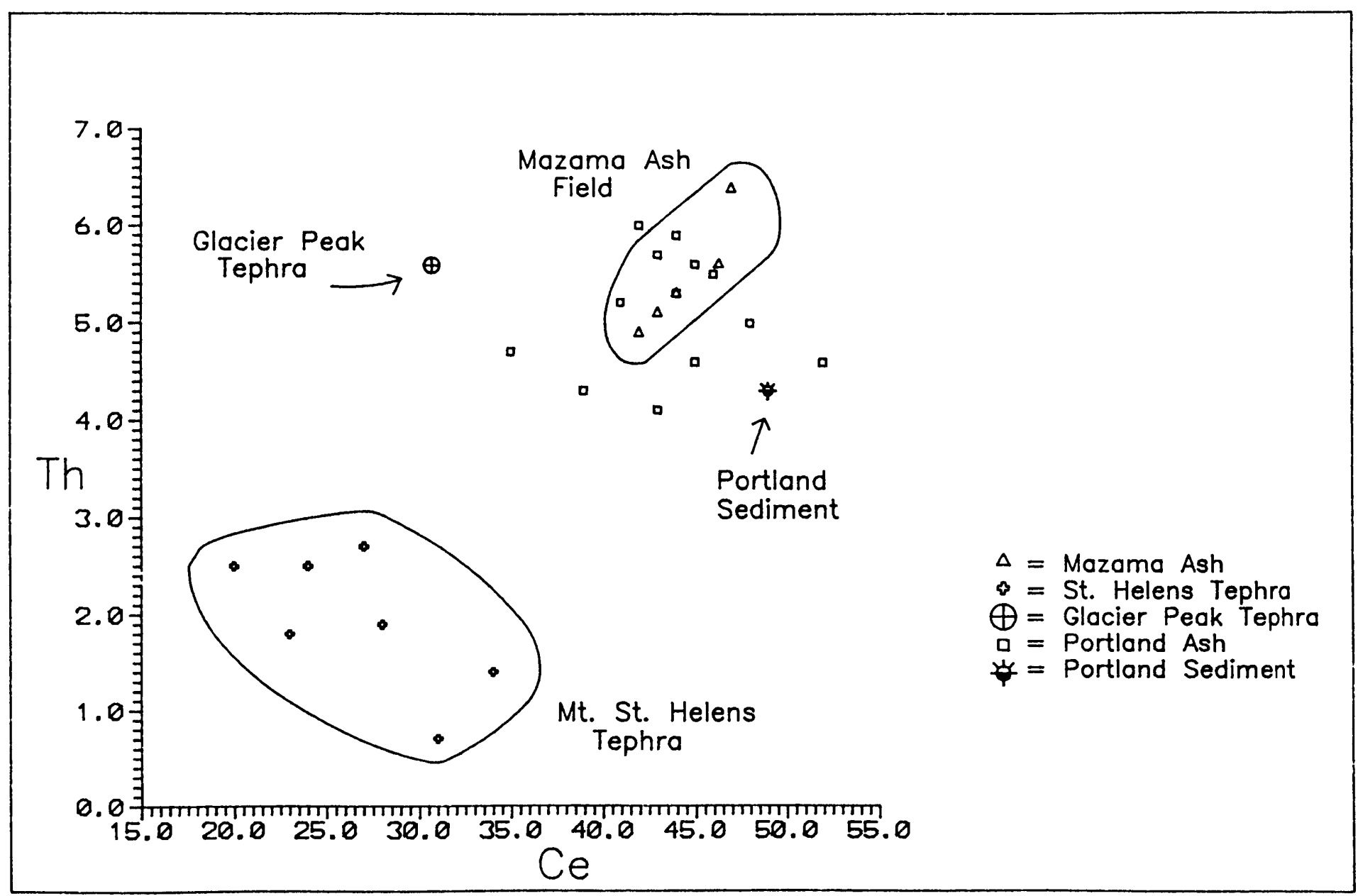

Eigure A-8. Cerium vs. Thorium; Portland area sample sites. 


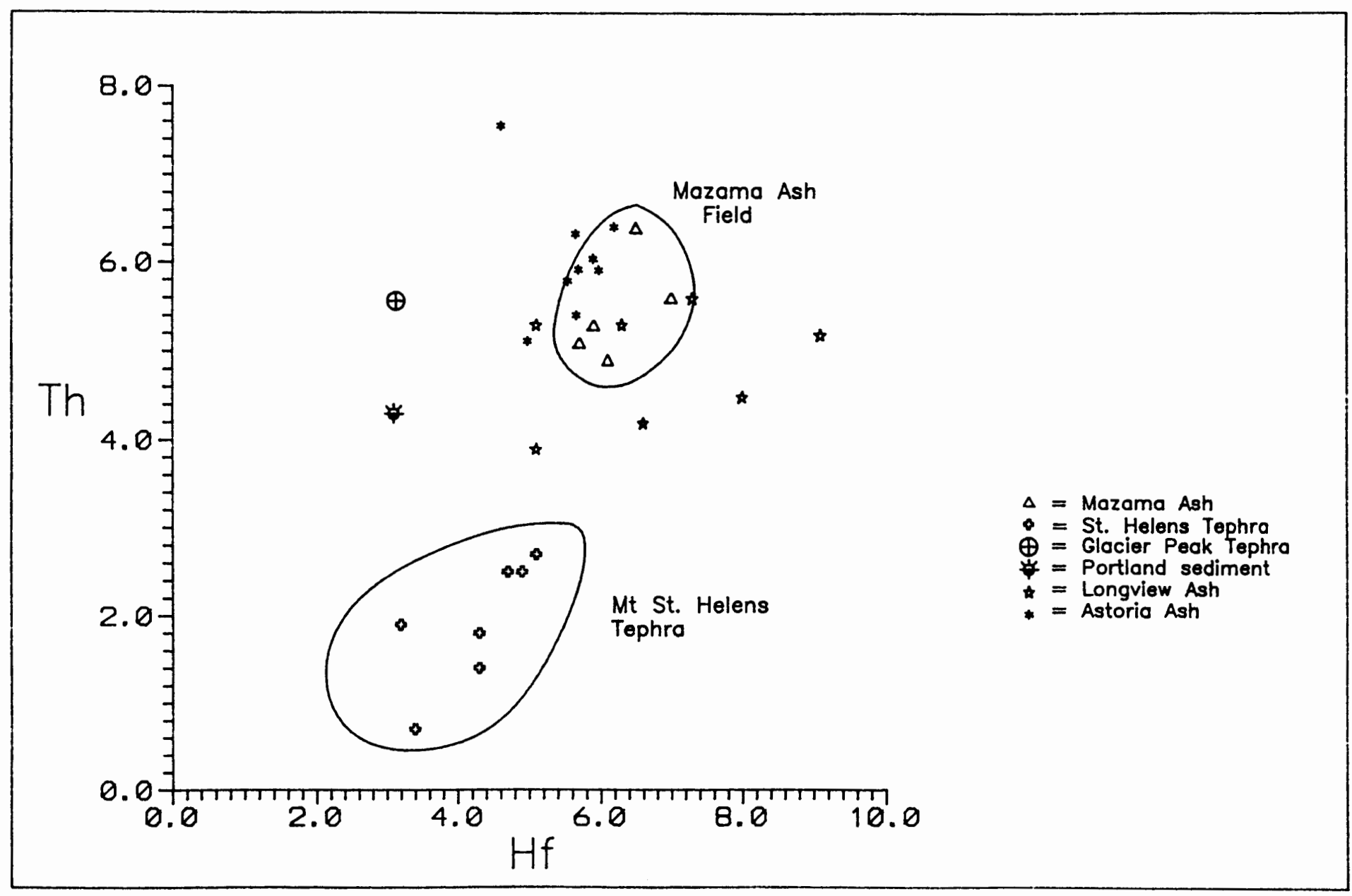

Eigure A-9 Hofnium vs. Thorium; Longview and Astorio areo somple sites. 


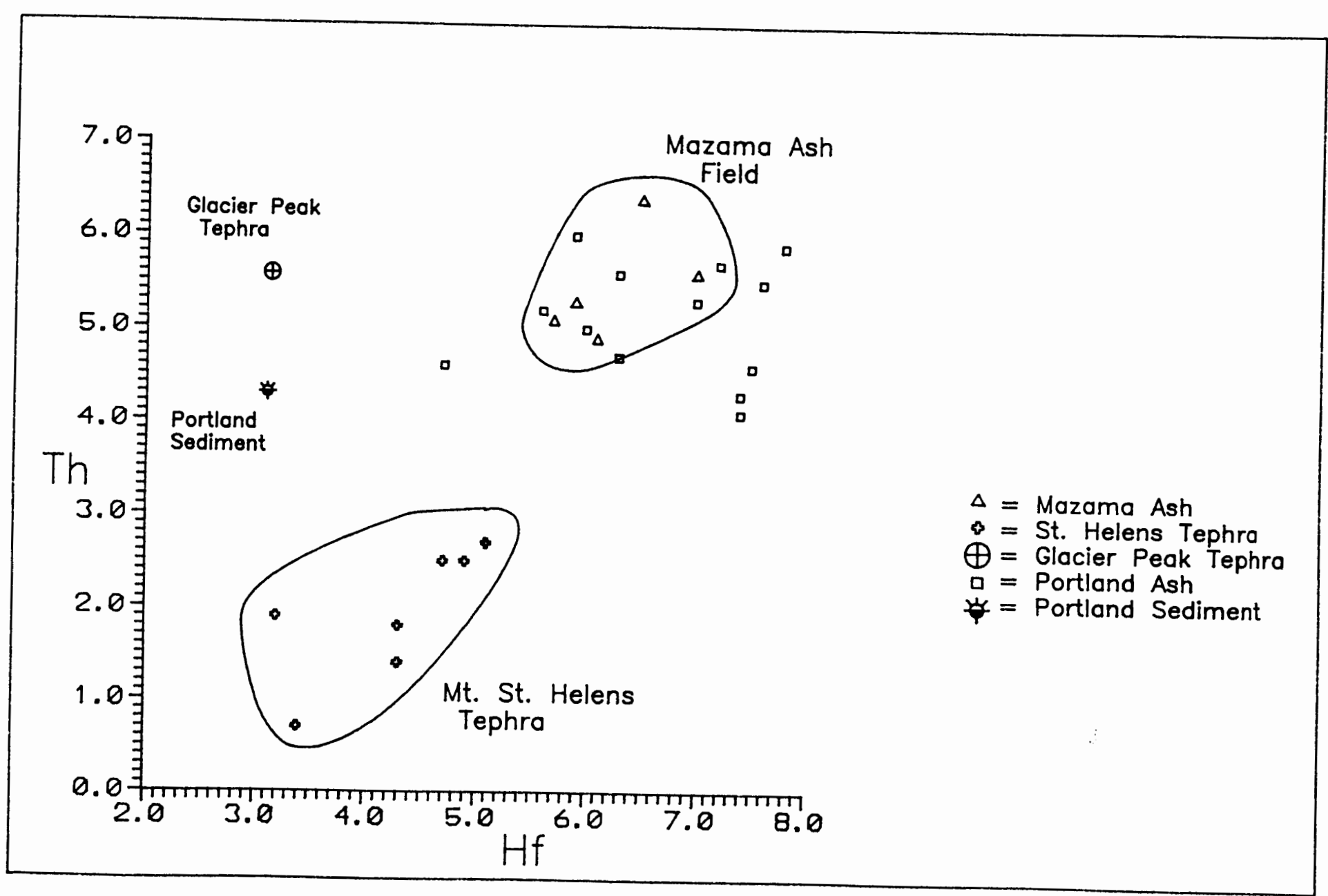

Eigure $A-10 \quad$ Hafnium vs. Thorium; Portland area somple sites. 


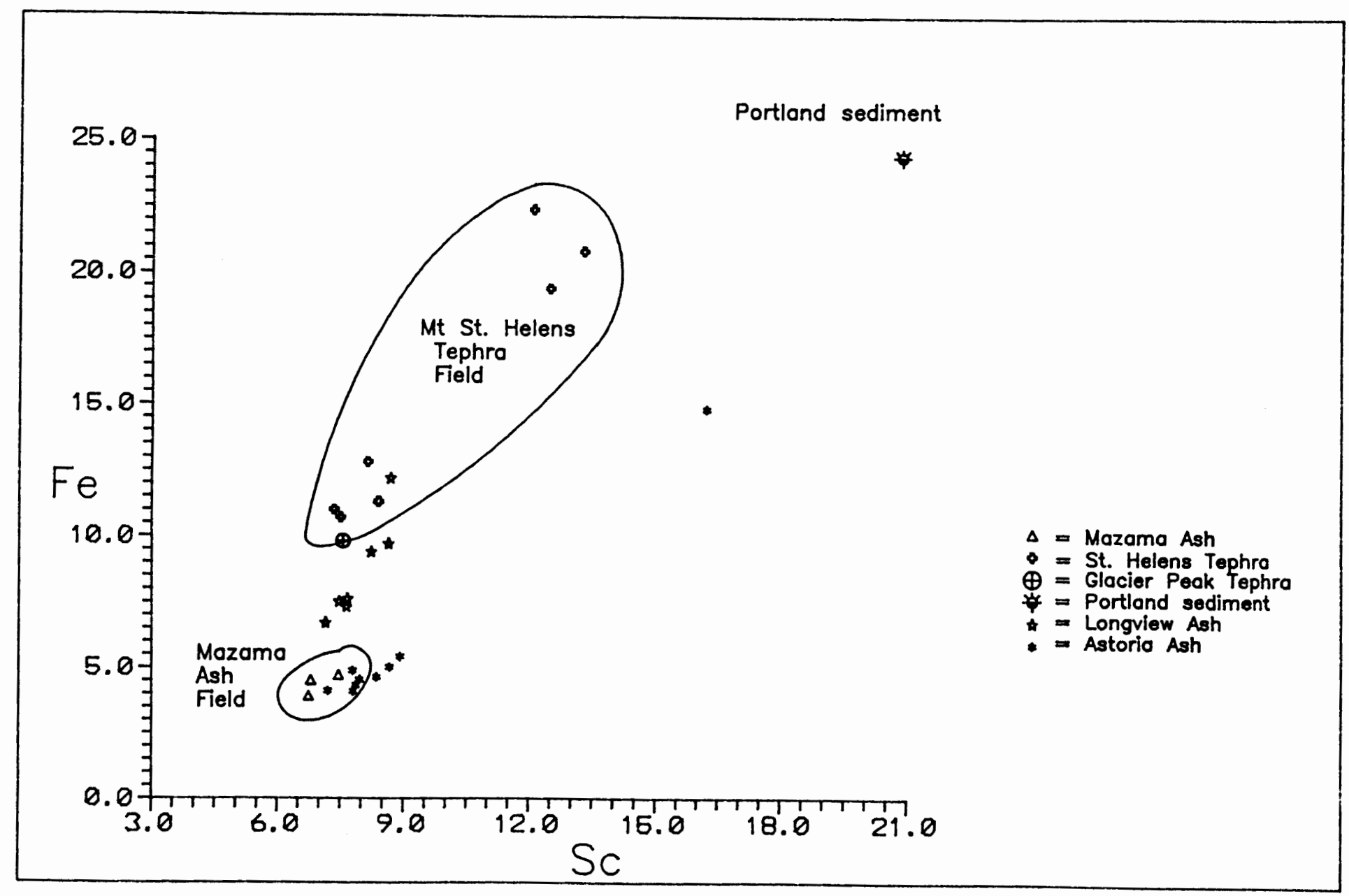

Eigure A-11 Scondium vs. Cobolt; Longview and Astorio oreo somple sites. 


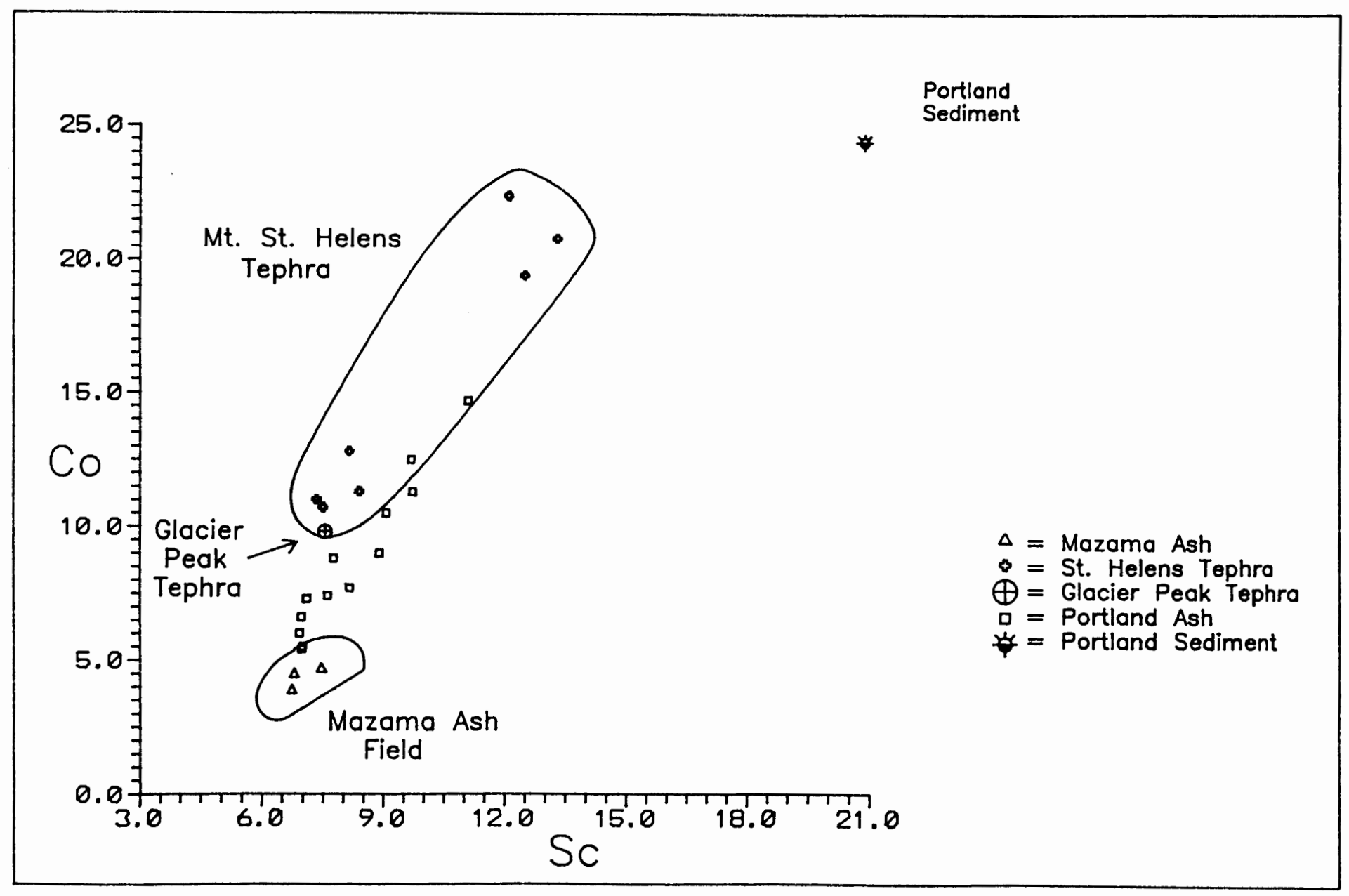

Eiqure A-12. Scandium vs. Cobalt; Portland area sample sites. 


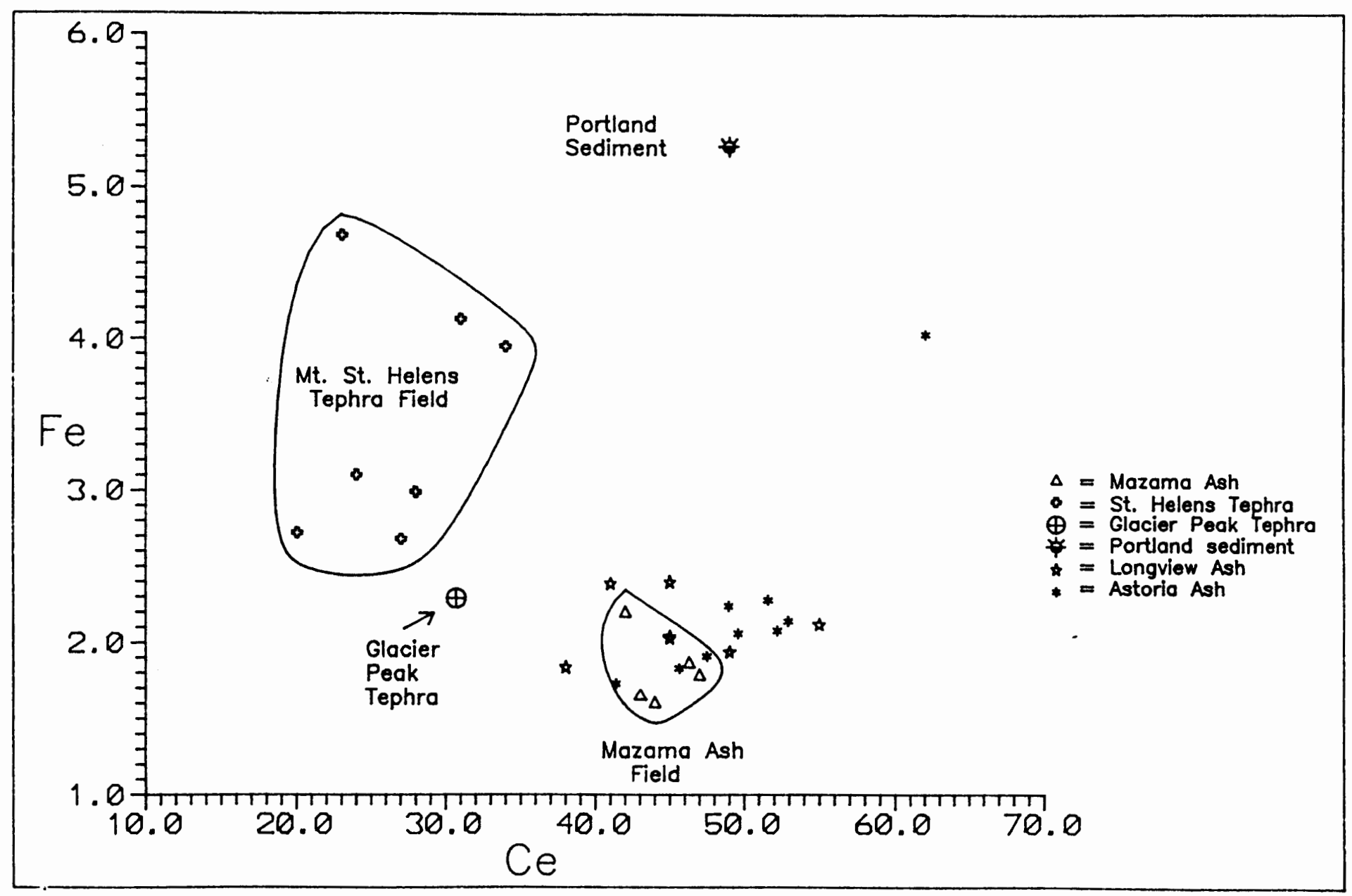

Eigure $A-13$. Cerium vs. Iron; Longview and Astoria area sample sites. 


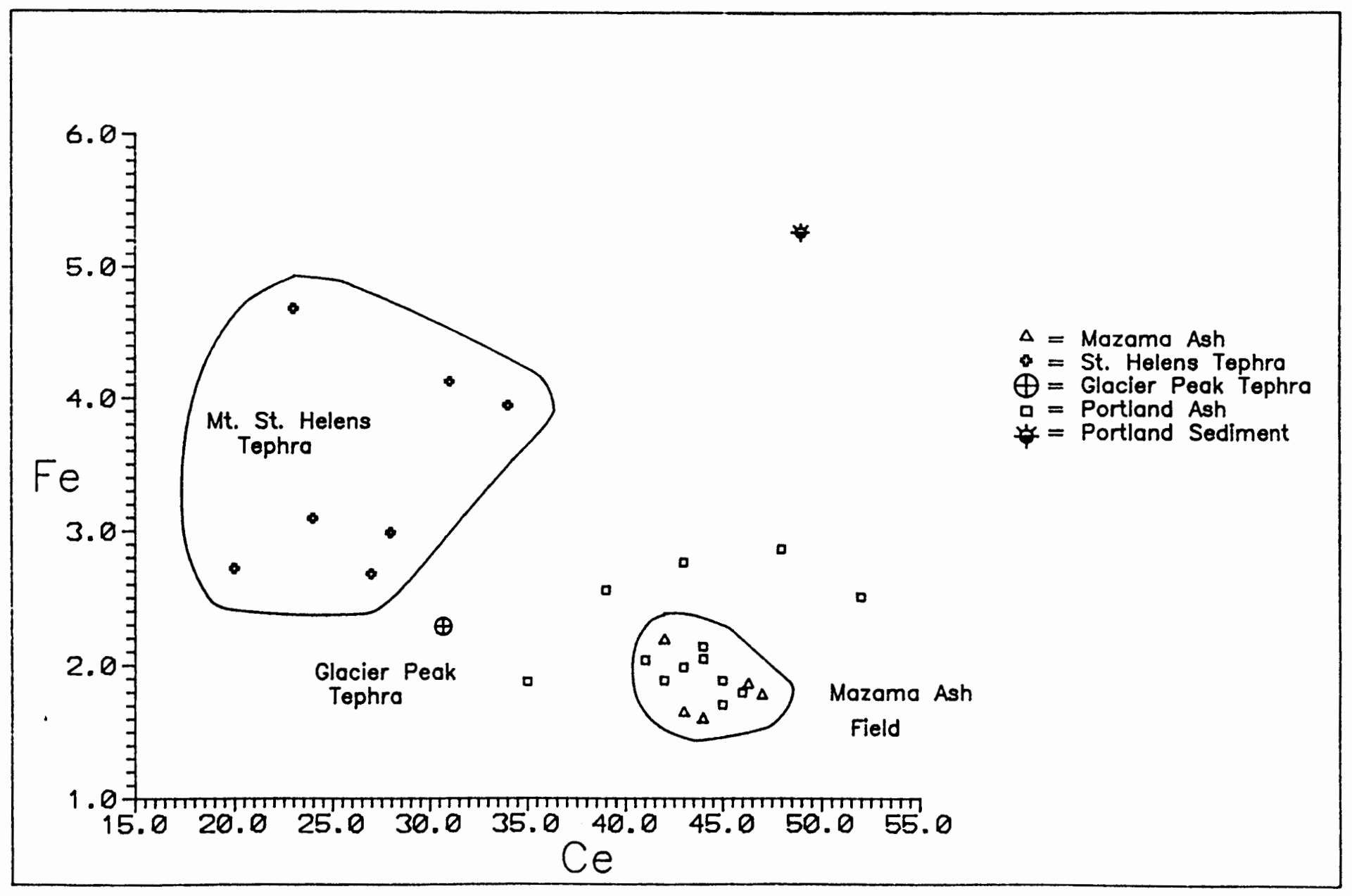

Eigure A-14 Cerium vs. Iron; Portland area sample sites. 


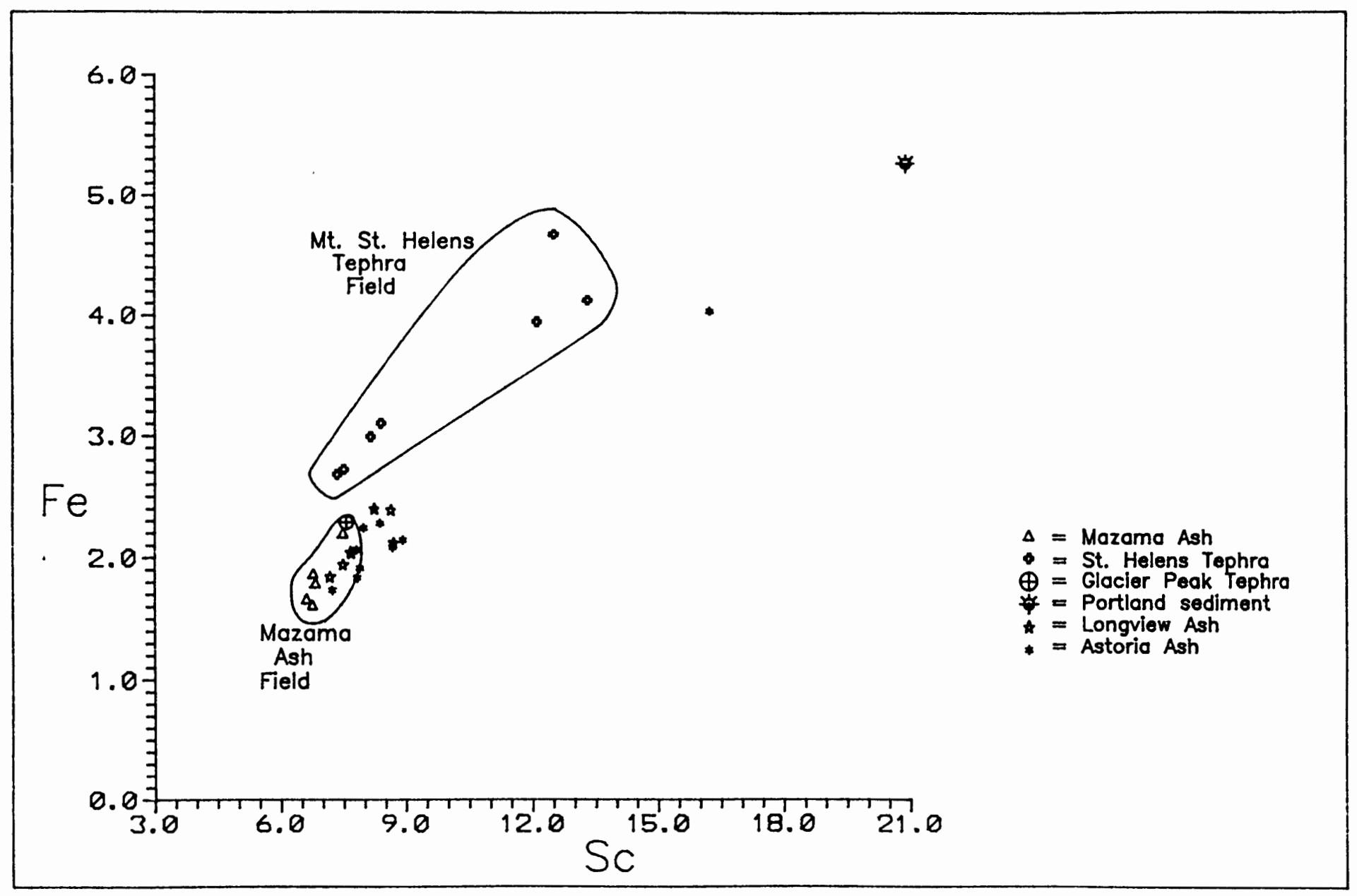

Eigure A-15. Scandium vs. Iron; Longview and Astoria area sample sites. 


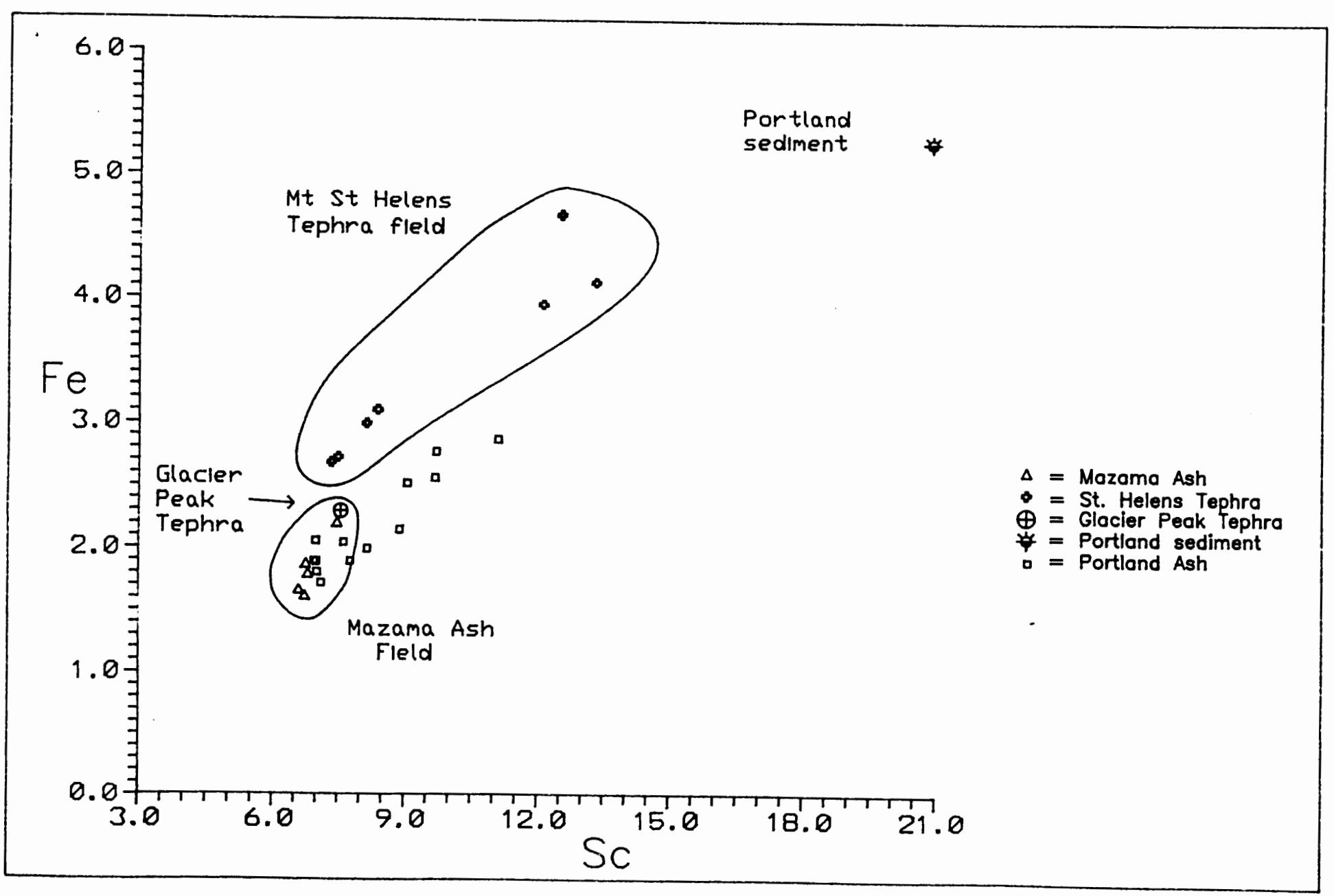

Eigure $A-16$ Scandium vs. Iron; Portland area sample sites. 
APPENDIX B

DATA BASE OF BOREHOLE RECORDS 
Listed below is an explanation of how this data base was constructed including the methods used for interpretation.

Data for the last 163 records (Pt \# 1324 through Pt \# 1487) were taken from DOGAMI's Portland area seismic database. The database was compiled by Ian Maiden and generously donated by DOGAMI. Only those points from the DOGAMI database that fell within the floodplain boundaries and were not from duplicate borehole logs already compiled by the author were used.

Column 1 - Location: General description of the borehole location. Water well designations are based on the official system for rectangular subdivision of public lands, referenced to the Willamette Base Line and Meridian. Many of the water wells were located in the center of their respective grid section if the well log did not indicate a quarter section reference. Also, for the sections that had multiple well occurrences without any quarter section reference, only one well log was chosen to represent that particular section; generally the well chosen was one that penetrated the underlying strata below the Holocene alluvium. This location designation was common for the Sauvie Island water wells and some of the wells on the Lewis River delta.

Column 2 - Map ID\#: Map identification Number that represents the unique designation for each borehole log incorporated into the data set and displayed on all maps in the thesis.

Column 3 - UTM EAST: Universal Transverse Mercator grid position in zone 10. All values are in meters and increase eastward.

Column 4 - UTM NORTH: Universal Transverse Mercator grid position north of the equator. All values are in meters and increase northward.

Column 5 - Surface Elev Ft: Surface Elevation in feet from sea level (USC\&GS datum) indicated on the borehole records. For the water wells where no surface elevation was given, the elevation was estimated from the nearest reference point (contour line or benchmark) indicated from the corresponding USGS 7.5 series topographic map. For boreholes in the Longview Washington area that indicated surface elevations from the slaughters Bar datum, elevations were corrected to the USC\&GS datum by adding 0.98 feet.

Column 6 - Hole Depth Ft: Depth of the borehole in feet.

Column 7 - Hole Base Ft: Hole Base Elevation in Feet; Base elevation in feet of the borehole.

Column 8 - QalBasal Contact ft: Qal Base Elevation in Feet; Elevation of the basal contact between the overlying unconsolidated Quaternary Alluvium (Qal) and the underlying Formation. The contact was interpreted by the author as the boundary between the fine-grained (Qal and Qff) unconsolidated deposits and the underlying (QfC, QMC, $\mathrm{Tt}, \mathrm{CRBG}$, or Ta) lithologies. The boundary was based on either a partition in grainsize, cementation, or density (interpreted from SPT blowcounts, or geophysical measurements) contrast. For boreholes that did not penetrate the underlying strata a value of zero appears for that data record. 
Column 9 - QalBasal ContactM: Qal Base Elevation in meters; Same as column $G$ in meters. These values were used to estimate isopach of gal and Qff for all of the maps that appear in the thesis.

Column 10 - GIS Code: Binary code used for all borehole logs to indicate if the borehole penetrated any formation or lithologic unit beneath the unconsolidated Quaternary alluvium. $0=$ no; $1=$ yes.

Column 11 - Basal Lithol: Lithology of the underlying strata below the unconsolidated alluvium, used as the boundary for the Holocene contact. Abbreviations for the lithologies listed on the borehole records are as follows: Rock = local basin pre-Holocene strata of unidentified lithology; $Q 1 s=$ landslide deposits; $S \& G(\& C)=$ sand and gravel (and cobbles); Grvl = gravel; GrCobbles= gravel and cobbles; Bouldr = boulders; Qff = fine grained facies of the late Quaternary catastrophic flood deposits; QfC = coarse grained facies of the late Quaternary catastrophic flood deposits; Tt = Troutdale Formation; SRM = Sandy River mudstone; Bslt = Basalt; Claystn = Claystone; Ast Frm = Astoria Formation; Gobel V. = Gobel volcanics.

Column 12 - Isopach feet: Isopach in feet; Thickness of Qal and Qff in feet. Includes fill material in some areas.

Column 13 - Isopach Meters: Isopach in meters; Thickness of Qal and off in meters. Includes fill material in some areas.

Column 14 - Ash Code: Binary code used to indicate the presence of the Mazama Ash occurrence. 1 = yes; $0=$ no.

Column 15 - SPT Min/Max: Standard Penetration test values reported as the minimum and maximum number of blows reported within the unconsolidated Quaternary alluvium. SPT is defined as the number of blows required to drive a 2 inch outer diameter sampler one foot using a 140 pound weight free falling 30 inches per blow. The asterisk (*) indicates the number of blows required to drive a Dames and Moore inc. type $U$ sampler one foot with 800 pound weight falling 24 inches per blow (also used to drive casing, personal communication with Dames and Moore inc.). 
Weyerhauser

Longview

Mt Coffin

site

Weyerhauser

Longview
Elev Ft Depth Ft Base Ft Contactft ContactM Code Lithol Feet Meters Code Min Max

$\begin{array}{rrrrrrrr}500775 & 5108222 & -16 & 6.5 & -22.5 & -22 & -6.7 & 1 \\ 500801 & 5108183 & -18 & 38 & -56 & & & 0 \\ 500828 & 5108152 & -20.5 & 35.5 & -56 & & & 0 \\ 500868 & 5108110 & -12.5 & 16.5 & -29 & -28 & -8.5 & 1 \\ 500789 & 5108201 & -19 & 34 & -53 & -52 & -15.8 & 1 \\ 500838 & 5108218 & 20 & 36.5 & -16.5 & -16 & -4.9 & 1 \\ & & & & & & & \\ 501141 & 5108509 & 15.5 & 93 & -77.5 & 0 & 0.0 & 0 \\ 501183 & 5108557 & 15.5 & 76.5 & -61 & 0 & 0.0 & 0 \\ 501358 & 5108168 & 15.5 & 62 & -46.5 & 0 & 0.0 & 0 \\ 501491 & 5108310 & 15.5 & 60 & -44.5 & 0 & 0.0 & 0 \\ 501455 & 5108261 & 15.5 & 60 & -44.5 & 0 & 0.0 & 0 \\ 501368 & 5108364 & 15.5 & 80 & -64.5 & 0 & 0.0 & 0 \\ 501304 & 5108416 & 17 & 205 & -188 & 0 & 0.0 & 0 \\ 501331 & 5108448 & 16 & 152 & -136 & 0 & 0.0 & 0 \\ 501324 & 5108443 & 16 & 212 & -196 & -193 & -58.8 & 1 \\ 501328 & 5108433 & 16 & 164 & -148 & 0 & 0.0 & 0 \\ 501307 & 5108421 & 17 & 155 & -138 & 0 & 0.0 & 0 \\ 501273 & 5108345 & 15 & 151 & -136 & 0 & 0.0 & 0 \\ 500907 & 5108720 & 16.5 & 72 & -55.5 & 0 & 0.0 & 0 \\ 500910 & 5108801 & 12.5 & 71.5 & -59 & 0 & 0.0 & 0 \\ 500966 & 5108864 & 11.5 & 100.5 & -89 & 0 & 0.0 & 0 \\ 501058 & 5108801 & 12 & 80.5 & -68.5 & 0 & 0.0 & 0 \\ 501005 & 5108778 & 15 & 71.5 & -56.5 & 0 & 0.0 & 0 \\ 501144 & 5108789 & 15 & 71.5 & -56.5 & 0 & 0.0 & 0 \\ 500836 & 5108815 & 17 & 30 & -13 & 0 & 0.0 & 0 \\ 500789 & 5108663 & 23.5 & 75.5 & -52 & 0 & 0.0 & 0 \\ 501108 & 5108589 & 16 & 148.5 & -132.5 & 0 & 0.0 & 0 \\ 501410 & 5108523 & 13 & 117 & -104 & 0 & 0.0 & 0 \\ 501074 & 5108859 & 15 & 102.5 & -87.5 & 0 & 0.0 & 0 \\ 501120 & 5108727 & 15 & 100.5 & -85.5 & 0 & 0.0 & 0 \\ 501093 & 5108772 & 15 & 181 & -166 & 0 & 0.0 & 0 \\ 500894 & 5108871 & 15 & 101 & -86 & 0 & 0.0 & 0 \\ 500927 & 5108840 & 15 & 155 & -140 & 0 & 0.0 & 0 \\ 500962 & 5108702 & 15 & 100.5 & -85.5 & 0 & 0.0 & 0 \\ 501003 & 5108915 & 15 & 100 & -85 & 0 & 0.0 & 0 \\ 500857 & 5108765 & 17 & 161 & -144 & 0 & 0.0 & 0 \\ 501480 & 5108596 & 15 & 192.5 & -177.5 & 0 & 0.0 & 0 \\ 500859 & 5108704 & 18 & 60.5 & -42.5 & 0 & 0.0 & 0 \\ 500805 & 5108792 & 19.5 & 74 & -54.5 & 0 & 0.0 & 0 \\ 500876 & 5108827 & 15 & 70 & -55 & 0 & 0.0 & 0\end{array}$

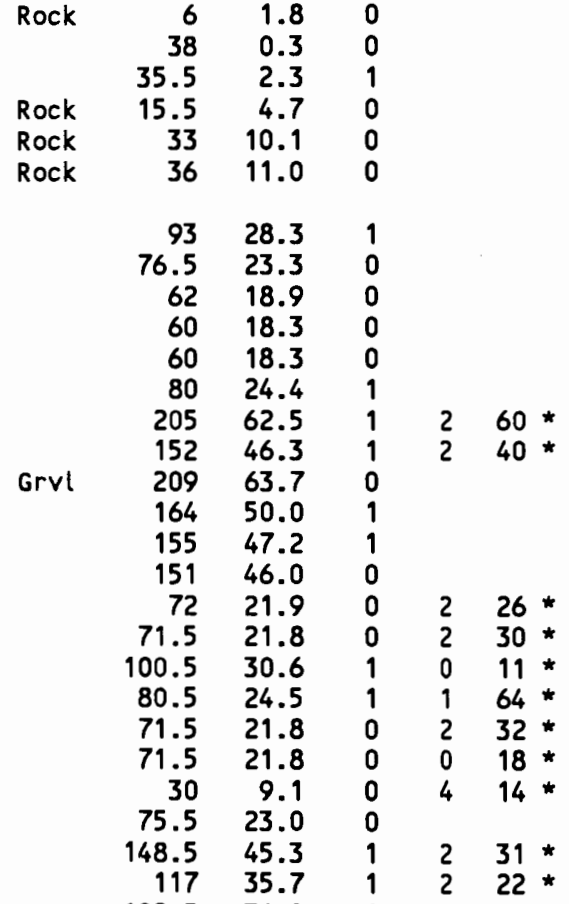

$100.5 \quad 30.6$

$\begin{array}{rrr}181 & 55.2 & 0 \\ 101 & 30.8 & 1 \\ 155 & 47.2 & 1 \\ 100.5 & 30.6 & 1 \\ 100 & 30.5 & 1 \\ 161 & 49.1 & 0 \\ 192.5 & 58.7 & 1 \\ 60.5 & 18.4 & 0 \\ 74 & 22.6 & 0 \\ 70 & 21.3 & 0\end{array}$ 


\begin{tabular}{|c|c|c|c|c|c|c|c|c|}
\hline . & $\begin{array}{l}41 \\
42 \\
43 \\
44 \\
45 \\
46 \\
47 \\
48 \\
49 \\
50 \\
51\end{array}$ & $\begin{array}{l}500906 \\
500966 \\
500973 \\
501004 \\
501073 \\
501041 \\
500797 \\
500914 \\
500867 \\
501064 \\
501013\end{array}$ & $\begin{array}{l}5108757 \\
5108774 \\
5108802 \\
5108732 \\
5108746 \\
5108783 \\
5108732 \\
5108635 \\
5108872 \\
5108719 \\
5108812\end{array}$ & $\begin{array}{r}17 \\
14.5 \\
14.5 \\
18 \\
15 \\
14 \\
21.5 \\
19.5 \\
13 \\
15 \\
12.5\end{array}$ & $\begin{array}{r}81 \\
70 \\
70 \\
85.5 \\
89 \\
70 \\
61 \\
60.5 \\
70 \\
70 \\
50\end{array}$ & $\begin{array}{r}-64 \\
-55.5 \\
-55.5 \\
-67.5 \\
-74 \\
-56 \\
-39.5 \\
-41 \\
-57 \\
-55 \\
-37.5\end{array}$ & $\begin{array}{l}0 \\
0 \\
0 \\
0 \\
0 \\
0 \\
0 \\
0 \\
0 \\
0 \\
0\end{array}$ & $\begin{array}{l}0.0 \\
0.0 \\
0.0 \\
0.0 \\
0.0 \\
0.0 \\
0.0 \\
0.0 \\
0.0 \\
0.0 \\
0.0\end{array}$ \\
\hline Weyerhauser & $\begin{array}{l}52 \\
53 \\
54 \\
55 \\
56 \\
57 \\
58 \\
59 \\
60 \\
61 \\
62 \\
63 \\
64 \\
65 \\
66 \\
67 \\
68 \\
69 \\
70 \\
71 \\
72 \\
73 \\
74 \\
75 \\
76 \\
77 \\
78 \\
79 \\
80 \\
81\end{array}$ & $\begin{array}{l}501275 \\
501226 \\
501348 \\
501363 \\
501321 \\
500844 \\
500907 \\
500864 \\
501799 \\
502046 \\
500692 \\
500593 \\
500518 \\
501695 \\
501848 \\
501929 \\
501749 \\
501786 \\
501854 \\
501774 \\
501838 \\
501907 \\
501960 \\
502017 \\
502107 \\
502166 \\
501293 \\
501793 \\
501786 \\
501917\end{array}$ & $\begin{array}{l}5108619 \\
5108608 \\
5108519 \\
5108542 \\
5108567 \\
5108332 \\
5108313 \\
5108369 \\
5107826 \\
5107711 \\
5108426 \\
5108557 \\
5108667 \\
5108004 \\
5107920 \\
5107847 \\
5108014 \\
5107937 \\
5107851 \\
5107981 \\
5107789 \\
5107693 \\
5107788 \\
5107674 \\
5107649 \\
5107688 \\
5108499 \\
5107908 \\
5107846 \\
5107809\end{array}$ & $\begin{array}{r}10 \\
10 \\
10 \\
10 \\
10 \\
24 \\
25 \\
25 \\
16 \\
17 \\
17.5 \\
17.5 \\
26.5 \\
17 \\
16.5 \\
15 \\
16 \\
16.5 \\
16.5 \\
16.5 \\
16 \\
16.5 \\
16 \\
16.5 \\
15.5 \\
15 \\
15.5 \\
16.5 \\
15.5 \\
15.5\end{array}$ & $\begin{array}{r}71.5 \\
101.5 \\
50 \\
86.5 \\
50 \\
152 \\
76.5 \\
71.5 \\
118 \\
105.5 \\
161 \\
173.5 \\
200.5 \\
109 \\
54.5 \\
179 \\
100 \\
20.5 \\
127 \\
61 \\
118 \\
110 \\
112 \\
197 \\
110 \\
177.5 \\
156.5 \\
17 \\
70.5 \\
70.5\end{array}$ & $\begin{array}{r}-61.5 \\
-91.5 \\
-40 \\
-76.5 \\
-40 \\
-128 \\
-51.5 \\
-46.5 \\
-102 \\
-88.5 \\
-143.5 \\
-156 \\
-174 \\
-92 \\
-38 \\
-164 \\
-84 \\
-3.5 \\
-110.5 \\
-44.5 \\
-102 \\
-93.5 \\
-96 \\
-180.5 \\
-94.5 \\
-162.5 \\
-141 \\
-0.5 \\
-55 \\
-55\end{array}$ & $\begin{array}{r}0 \\
0 \\
0 \\
0 \\
0 \\
0 \\
0 \\
0 \\
-101 \\
0 \\
0 \\
0 \\
0 \\
-84 \\
-38 \\
-164 \\
-84 \\
-3.5 \\
-107.5 \\
-43.5 \\
-102 \\
0 \\
0 \\
0 \\
0 \\
-162.5 \\
0 \\
-0.5 \\
0 \\
0\end{array}$ & $\begin{array}{r}0.0 \\
0.0 \\
0.0 \\
0.0 \\
0.0 \\
0.0 \\
0.0 \\
0.0 \\
-30.8 \\
0.0 \\
0.0 \\
0.0 \\
0.0 \\
-25.6 \\
-11.6 \\
-50.0 \\
-25.6 \\
-1.1 \\
-32.8 \\
-13.3 \\
-31.1 \\
0.0 \\
0.0 \\
0.0 \\
0.0 \\
-49.5 \\
0.0 \\
-0.2 \\
0.0 \\
0.0\end{array}$ \\
\hline
\end{tabular}

Surface Hole Hole QalBasal QalBasal GIS Basal Isopach I sopach Ash SPT
Elev Ft Depth Ft Base Ft Contactft ContactM Code Lithol Feet Meters Code Min Max

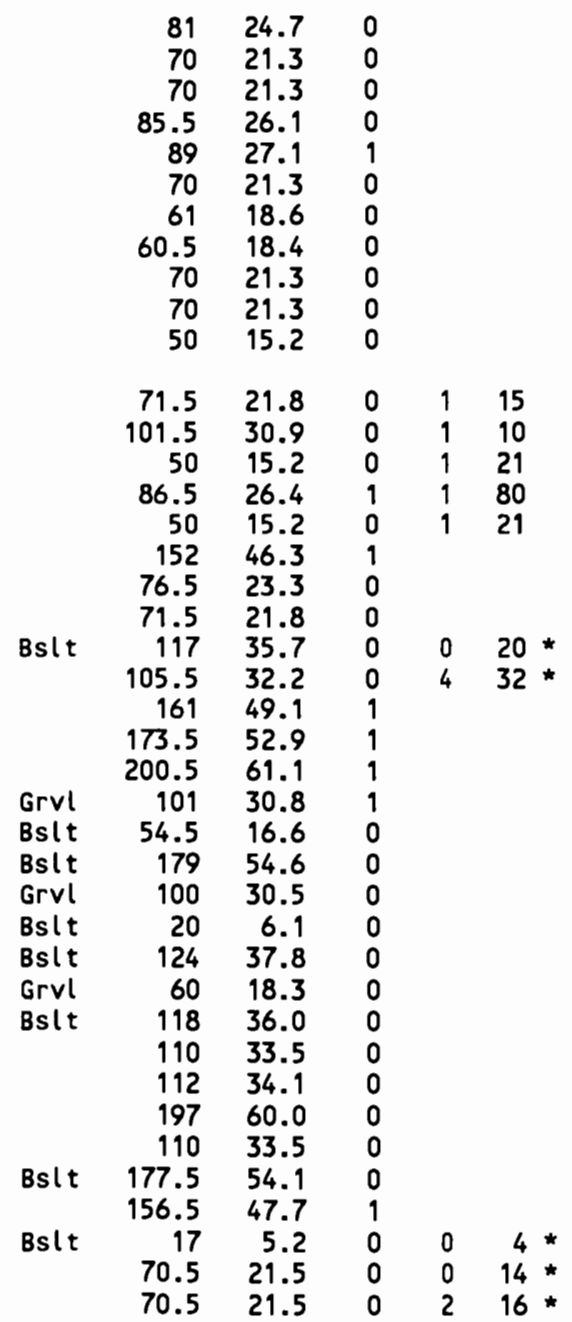



Elev Ft Depth Ft Base Ft Contactft ContactM Code Lithol Feet Meters Code Min Max

Reynolds Metals

Longview

\begin{tabular}{|c|c|c|c|c|c|}
\hline $\begin{array}{l}\text { Bslt } \\
\text { Bslt }\end{array}$ & $\begin{array}{r}70.5 \\
70 \\
36 \\
21.5 \\
70.5 \\
70.5 \\
70.5 \\
70.5\end{array}$ & $\begin{array}{r}21.5 \\
21.3 \\
11.0 \\
6.6 \\
21.5 \\
21.5 \\
21.5 \\
21.5\end{array}$ & $\begin{array}{l}0 \\
0 \\
0 \\
0 \\
0 \\
0 \\
0 \\
0\end{array}$ & 1 & 21 * \\
\hline $\begin{array}{r}\text { Tt } \\
\text { Grvl } \\
\text { Tt }\end{array}$ & $\begin{array}{r}81 \\
203 \\
209 \\
231 \\
97 \\
151.5 \\
98 \\
126 \\
100 \\
100 \\
102.5 \\
63 \\
225 \\
100 \\
152 \\
101.5 \\
100 \\
103 \\
100 \\
80 \\
82 \\
88 \\
88 \\
100 \\
100 \\
32 \\
32 \\
32 \\
32 \\
32 \\
32 \\
32 \\
32\end{array}$ & $\begin{array}{r}24.7 \\
61.9 \\
63.7 \\
70.4 \\
29.6 \\
46.2 \\
29.9 \\
38.4 \\
30.5 \\
30.5 \\
31.2 \\
19.2 \\
68.6 \\
30.5 \\
46.3 \\
30.9 \\
30.5 \\
31.4 \\
30.5 \\
24.4 \\
25.0 \\
26.8 \\
26.8 \\
30.5 \\
30.5 \\
9.8 \\
9.8 \\
9.8 \\
9.8 \\
9.8 \\
9.8 \\
9.8 \\
9.8\end{array}$ & $\begin{array}{l}1 \\
0 \\
0 \\
0 \\
1 \\
1 \\
1 \\
0 \\
1 \\
1 \\
1 \\
0 \\
1 \\
1 \\
1 \\
1 \\
0 \\
1 \\
1 \\
0 \\
0 \\
1 \\
1 \\
1 \\
0 \\
0 \\
0 \\
0 \\
0 \\
0 \\
0 \\
0 \\
0\end{array}$ & $\begin{array}{l}1 \\
2\end{array}$ & 18 * \\
\hline
\end{tabular}


Hole QalBasal QalBasal Gis

Basal

I sopach I sopach Ash

SPT

Elev Ft Depth Ft Base Ft ContactFt ContactM Code Lithol Feet Meters Code Min Max

$\begin{array}{rrrrrrrrl}123 & 499911 & 5109469 & 10.2 & 103 & -92.8 & 0 & 0.0 & 0 \\ 124 & 499873 & 5109360 & 11.4 & 92 & -80.6 & 0 & 0.0 & 0 \\ 125 & 499955 & 5109316 & 11 & 117 & -106 & 0 & 0.0 & 0 \\ 126 & 500022 & 5109217 & 12.2 & 135 & -122.8 & 0 & 0.0 & 0 \\ 127 & 500100 & 5109314 & 10.4 & 132 & -121.6 & 0 & 0.0 & 0 \\ 128 & 500192 & 5109380 & 8.9 & 101.5 & -92.6 & 0 & 0.0 & 0 \\ 129 & 500038 & 5109530 & 6 & 73 & -67 & 0 & 0.0 & 0 \\ 130 & 500037 & 5109499 & 6 & 70 & -64 & 0 & 0.0 & 0 \\ 131 & 500094 & 5109632 & 6 & 70 & -64 & 0 & 0.0 & 0 \\ 132 & 500068 & 5109606 & 6 & 70 & -64 & 0 & 0.0 & 0 \\ 133 & 500046 & 5109436 & 6 & 71 & -65 & 0 & 0.0 & 0 \\ 134 & 499992 & 5109472 & 6 & 40 & -34 & 0 & 0.0 & 0 \\ 135 & 499930 & 5109589 & 7.5 & 72.5 & -65 & 0 & 0.0 & 0 \\ 136 & 499894 & 5109556 & 6.5 & 70 & -63.5 & 0 & 0.0 & 0 \\ 137 & 499768 & 5109374 & 12 & 223 & -211 & 0 & 0.0 & 0 \\ 138 & 499781 & 5109431 & 12 & 80 & -68 & 0 & 0.0 & 0 \\ 139 & 499820 & 5109386 & 12 & 215 & -203 & 0 & 0.0 & 0 \\ 140 & 499917 & 5109327 & 10 & 211 & -201 & -200 & -61.0 & 1 \\ 141 & 499930 & 5109263 & 10 & 92 & -82 & 0 & 0.0 & 0 \\ 142 & 499876 & 5108957 & -26 & 100 & -126 & 0 & 0.0 & 0 \\ 143 & 499988 & 5108855 & -36 & 90 & -126 & 0 & 0.0 & 0 \\ 144 & 500086 & 5108776 & -51.5 & 48 & -99.5 & 0 & 0.0 & 0 \\ 145 & 499842 & 5109967 & 6.1 & 100 & -93.9 & 0 & 0.0 & 0 \\ 146 & 499916 & 5110097 & 4.8 & 80 & -75.2 & 0 & 0.0 & 0 \\ 147 & 499922 & 5108887 & -40.5 & 127 & -167.5 & 0 & 0.0 & 0 \\ 148 & 499980 & 5108821 & -44.5 & 136 & -180.5 & -178.5 & -54.4 & 1 \\ 149 & 500010 & 5108807 & -40.5 & 140.5 & -181 & -179.5 & -54.7 & 1 \\ 150 & 499635 & 5110007 & 11 & 74.5 & -63.5 & 0 & 0.0 & 0 \\ 151 & 499688 & 5109968 & 11 & 62 & -51 & 0 & 0.0 & 0 \\ 152 & 499717 & 5109934 & 10.5 & 87.5 & -77 & 0 & 0.0 & 0 \\ 153 & 499677 & 5110006 & 11 & 70 & -59 & 0 & 0.0 & 0 \\ 154 & 499725 & 5109966 & 11 & 67 & -56 & 0 & 0.0 & 0 \\ 155 & 499661 & 5110120 & 4 & 25.5 & -21.5 & 0 & 0.0 & 0 \\ 156 & 499779 & 5110074 & 7 & 23.5 & -16.5 & 0 & 0.0 & 0 \\ 157 & 499829 & 5110029 & 7 & 25.5 & -18.5 & 0 & 0.0 & 0 \\ 158 & 499883 & 5110000 & 7.5 & 25.5 & -18 & 0 & 0.0 & 0 \\ 159 & 499671 & 5110170 & 5 & 109.5 & -104.5 & 0 & 0.0 & 0 \\ 160 & 499700 & 5110096 & 6.5 & 96.5 & -90 & 0 & 0.0 & 0 \\ 161 & 499735 & 5110136 & 5 & 98.5 & -93.5 & 0 & 0.0 & 0 \\ 162 & 499763 & 5110104 & 5 & 103 & -98 & 0 & 0.0 & 0 \\ 163 & 499820 & 5110053 & 5.5 & 106 & -100.5 & 0 & 0.0 & 0 \\ 164 & 499866 & 5110020 & 9 & 113.5 & -104.5 & 0 & 0.0 & 0\end{array}$

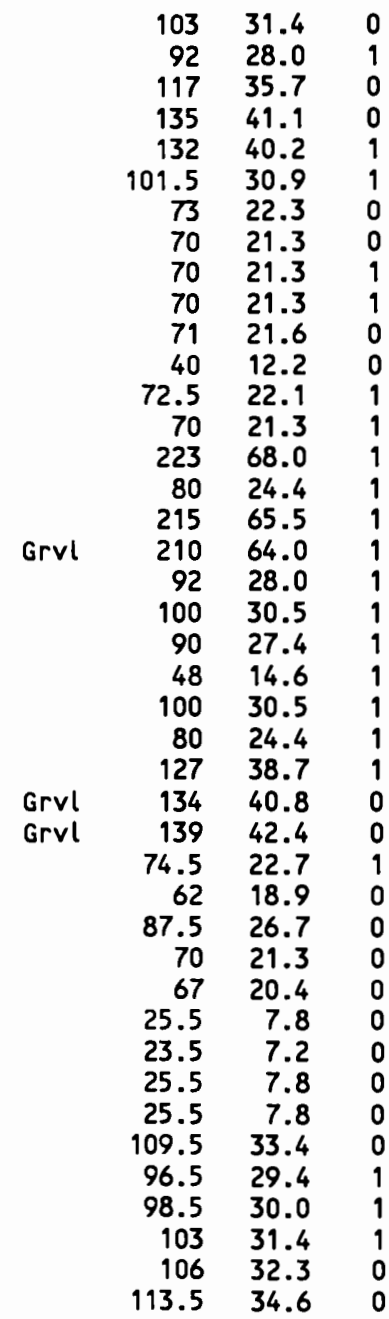

230 *

$226 *$

$222 *$

$420 *$ 
Elev Ft Depth Ft Base Ft ContactFt ContactM Code Lithol Feet Meters Code Min Max

Newsprint

Plant

Longview

Retirement Home

Longview Wa.

Longview Bank

$165 \quad 499835$

5109936

$499870 \quad 5110124$

$499700 \quad 5110147$

$499571 \quad 5110187$

$499837 \quad 5110042$

$499732 \quad 5110063$

$499563 \quad 5110136$

$499783 \quad 5109980$

$499691 \quad 5110039$

$499554 \quad 5110061$

$499609 \quad 5109946$

$499772 \quad 5109867$

$499672 \quad 5109841$

$\begin{array}{rrr}8 & 90.5 & -82.5 \\ 6.2 & 100.2 & -94 \\ 5.5 & 53.5 & -48 \\ 5 & 69.5 & -64.5 \\ 4.4 & 46.4 & -42 \\ 5.1 & 62.1 & -57 \\ 5.1 & 61.1 & -56 \\ 3.3 & 49.3 & -46 \\ 5.6 & 42.6 & -37 \\ 2.3 & 41.8 & -39.5 \\ 4.2 & 50.2 & -46 \\ 4.5 & 50.5 & -46 \\ 6 & 52 & -46 \\ 5 & 51 & -46\end{array}$

$\begin{array}{rlll}-82.5 & 0 & 0.0 & 0\end{array}$

$\begin{array}{ll}0.0 & 0 \\ 0.0 & 0\end{array}$

$0.0 \quad 0$

$0.0 \quad 0$

$0.0 \quad 0$

$0.0 \quad 0$

$0.0 \quad 0$

$\begin{array}{ll}0.0 & 0 \\ 0.0 & 0\end{array}$

$0.0 \quad 0$

$\begin{array}{ll}0.0 & 0 \\ 0.0 & 0\end{array}$

4995375109935

0.00

$505076 \quad 5107947$

$505115 \quad 5107992$

$\begin{array}{lll}18 & 90 & -72\end{array}$

$505106 \quad 5108053$

$\begin{array}{rrr}18 & 90 & -72 \\ 16 & 72 & -56 \\ 15 & 51.5 & -36.5\end{array}$

0.00

$504603 \quad 5109899$

$\begin{array}{rrr}16.5 & 81.5 & -65\end{array}$

$504618 \quad 5109859$

16.5

$504591 \quad 5109795$

14.5

$-22.5$

505079

5109091

19
18

$98.5 \quad-79.5$

$56.5-38.5$

505062

5109056

5109014

18
18

$55-37$

$505086 \quad 5109063$

18.5

$\begin{array}{lr}55 & -37 \\ 54 & -35.5\end{array}$

0.00

Longview Fibre

$190 \quad 506300$

5105497

5062215105292

$506561 \quad 5105311$

14
14

$122.5-108.5$

$\begin{array}{lll}15.6 & 137.1-121.5\end{array}$

$\begin{array}{lll}15.6 & 171.2 & -155.6\end{array}$

$\begin{array}{lll}194 & 506493 & 5105267\end{array}$

$\begin{array}{lll}15.5 & 171.5 & -156\end{array}$

195

$506523 \quad 5105381$

$151.5-136$

Internat. Paper

$196 \quad 504729 \quad 5104969$

$-24$

48.

$-72.5$

$\begin{array}{lll}197 & 503565 & 5106291 \\ 198 & 503533 & 5106238 \\ 199 & 503469 & 5106135\end{array}$

Longview Bridge

200

503407

5106033

18.5
27

23.6
22.5

182
70
50
55

$\begin{array}{rrrrr}182 & -163.5 & -159.5 & -48.6 & 1 \\ 70 & -43 & 0 & 0.0 & 0 \\ 50 & -26.4 & 0 & 0.0 & 0 \\ 55 & -32.5 & 0 & 0.0 & 0\end{array}$

$0.0 \quad 0$

$0.0 \quad 0$

$0.0 \quad 0$

$0.0 \quad 0$

$\begin{array}{ll}0.0 & 0 \\ 0.0 & 0\end{array}$

$\begin{array}{ll}0.0 & 0 \\ 0.0 & 0\end{array}$

0.00

$\begin{array}{ll}0.0 & 0 \\ 0.0 & 0\end{array}$

0.00

$0.0 \quad 0$$$
0.00
$$

$-48.6 \quad 1$

$\begin{array}{ll}0.0 & 0 \\ 0.0 & 0\end{array}$ $\begin{array}{rrr}90.5 & 27.6 & 0\end{array}$

$\begin{array}{ll}53.5 & 16.3\end{array}$

$\begin{array}{lll}69.5 & 21.2 & 0\end{array}$

$\begin{array}{lll}46.4 & 14.1 & 0\end{array}$

$62.1 \quad 18.9$

$61.1 \quad 18.6$

$49.3 \quad 15.0$

$\begin{array}{lll}42.6 & 13.0 & 0\end{array}$

$\begin{array}{lll}41.8 & 12.7 & 0\end{array}$

$50.2 \quad 15.3$

$\begin{array}{lll}50.5 & 15.4 & 0\end{array}$

$\begin{array}{lll}52 & 15.8 & 0 \\ 51 & 15.5 & 0\end{array}$

$\begin{array}{lllll}90 & 27.4 & 1 & 1 & 28 \\ 72 & 21 & \text { * }\end{array}$

$\begin{array}{rrrrr}72 & 21.9 & 0 & 1 & 26 \\ 51.5 & 15.7 & 0 & 2 & 31 *\end{array}$

$81.5 \quad 24.8 \quad 0$

$\begin{array}{lll}72 & 21.9 & 0 \\ 37 & 11.3 & 0\end{array}$

$\begin{array}{lllll}98.5 & 30.0 & 0 & 2 & 42\end{array}$

$\begin{array}{lllll}56.5 & 17.2 & 0 & 2 & 40\end{array}$

$\begin{array}{lllll}55 & 16.8 & 0 & 4 & 35\end{array}$

$\begin{array}{lllll}\mathbf{5 5} & 16.8 & 0 & 3 & 31 \\ \mathbf{5 4} & 16.5 & 0 & 2 & 26\end{array}$

$\begin{array}{rrr}122.5 & 37.3 & 1 \\ 122 & 37.2 & 0\end{array}$

$\begin{array}{lllll}137.1 & 41.8 & 1 & 5 & 39\end{array}$ *

$\begin{array}{lllll}171.2 & 52.2 & 1 & 2 & 37\end{array}$

$\begin{array}{lllll}171.5 & 52.3 & 1 & 5 & 42 \\ 151.5 & 46.2 & 1 & 3 & 38 \text { * }\end{array}$

$151.546 .21-338$ *

$48.514 .8 \quad 0 \quad 320$ *

Grvl $\quad \begin{array}{lll}178 & 54.3 & 0\end{array}$

$\begin{array}{lll}70 & 21.3 & 0 \\ 50 & 15.2 & 0 \\ 55 & 16.8 & 0\end{array}$ 
Elev Ft Depth Ft Base Ft Contactft ContactM Code Lithol Feet Meters Code Min Max

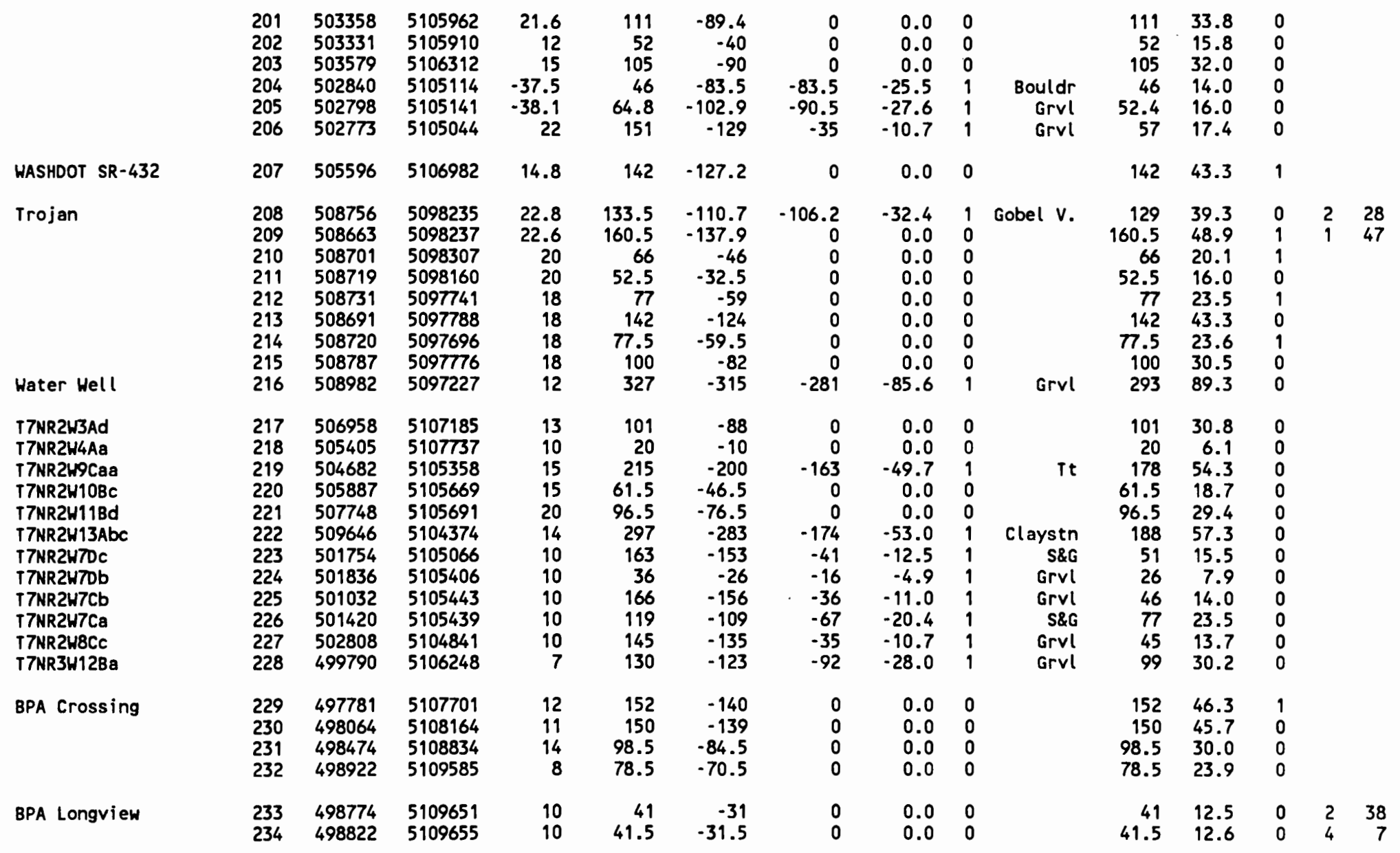




\begin{tabular}{|c|c|c|c|c|c|c|c|c|c|c|c|c|c|c|c|}
\hline Location & Map ID\# & UTM EAST & UTM NORTH & $\begin{array}{l}\text { Surface } \\
\text { Elev Ft }\end{array}$ & $\begin{array}{l}\text { Hole } \\
\text { Depth Ft }\end{array}$ & $\begin{array}{l}\text { Hole } \\
\text { Base Ft }\end{array}$ & $\begin{array}{l}\text { QalBasal } \\
\text { Contactft }\end{array}$ & $\begin{array}{l}\text { QalBasal } \\
\text { ContactM }\end{array}$ & $\begin{array}{l}\text { GIS } \\
\text { Code }\end{array}$ & $\begin{array}{l}\text { Basal } \\
\text { Lithol }\end{array}$ & $\begin{array}{l}\text { I sopach } \\
\text { Feet }\end{array}$ & $\begin{array}{l}\text { I sopach } \\
\text { Meters }\end{array}$ & $\begin{array}{l}\text { Ash } \\
\text { Code }\end{array}$ & & $\begin{array}{l}\text { PT } \\
n \text { Max }\end{array}$ \\
\hline CERRO COIP & $\begin{array}{l}235 \\
236 \\
237\end{array}$ & $\begin{array}{l}497937 \\
497640 \\
497174\end{array}$ & $\begin{array}{l}5111132 \\
5111014 \\
5110817\end{array}$ & $\begin{array}{r}4 \\
3 \\
11\end{array}$ & $\begin{array}{r}135.5 \\
187 \\
150\end{array}$ & $\begin{array}{r}-131.5 \\
-184 \\
-139\end{array}$ & $\begin{array}{r}-128 \\
0 \\
0\end{array}$ & $\begin{array}{r}-39.0 \\
0.0 \\
0.0\end{array}$ & $\begin{array}{l}1 \\
0 \\
0\end{array}$ & Bslt & $\begin{array}{l}132 \\
187 \\
150\end{array}$ & $\begin{array}{l}40.2 \\
57.0 \\
45.7\end{array}$ & $\begin{array}{l}1 \\
1 \\
1\end{array}$ & & \\
\hline $\begin{array}{l}\text { Proposed Grain } \\
\text { Storage Fac. } \\
\text { Longview }\end{array}$ & $\begin{array}{l}238 \\
239 \\
240 \\
241 \\
242 \\
243 \\
244 \\
245\end{array}$ & $\begin{array}{l}498639 \\
498514 \\
498551 \\
498772 \\
498807 \\
498618 \\
498418 \\
498448\end{array}$ & $\begin{array}{l}5109682 \\
5109658 \\
5109766 \\
5109600 \\
5109701 \\
5109624 \\
5109676 \\
5109788\end{array}$ & $\begin{array}{r}10.7 \\
13.2 \\
5.4 \\
15.4 \\
5.4 \\
14.2 \\
15.7 \\
6\end{array}$ & $\begin{array}{r}147.7 \\
141.2 \\
76.4 \\
142.4 \\
101.4 \\
141.2 \\
141.7 \\
142\end{array}$ & $\begin{array}{l}-137 \\
-128 \\
-71 \\
-127 \\
-96 \\
-127 \\
-126 \\
-136\end{array}$ & $\begin{array}{l}0 \\
0 \\
0 \\
0 \\
0 \\
0 \\
0 \\
0\end{array}$ & $\begin{array}{l}0.0 \\
0.0 \\
0.0 \\
0.0 \\
0.0 \\
0.0 \\
0.0 \\
0.0\end{array}$ & $\begin{array}{l}0 \\
0 \\
0 \\
0 \\
0 \\
0 \\
0 \\
0\end{array}$ & & $\begin{array}{r}147.7 \\
141.2 \\
76.4 \\
142.4 \\
101.4 \\
141.2 \\
141.7 \\
142\end{array}$ & $\begin{array}{l}45.0 \\
43.0 \\
23.3 \\
43.4 \\
30.9 \\
43.0 \\
43.2 \\
43.3\end{array}$ & $\begin{array}{l}1 \\
1 \\
1 \\
1 \\
1 \\
1 \\
1 . \\
1\end{array}$ & $\begin{array}{l}2 \\
4 \\
3 \\
8 \\
2 \\
4 \\
5 \\
4\end{array}$ & $\begin{array}{r}83 \\
30 \\
17 \\
75 \\
180 \\
105 \\
50 \\
33\end{array}$ \\
\hline $\begin{array}{l}\text { Willow Grove } \\
\text { Island }\end{array}$ & $\begin{array}{l}246 \\
247 \\
248 \\
249\end{array}$ & $\begin{array}{l}493205 \\
492833 \\
493406 \\
492644\end{array}$ & $\begin{array}{l}5114389 \\
5113587 \\
5113805 \\
5114213\end{array}$ & $\begin{array}{l}10 \\
10 \\
10 \\
10\end{array}$ & $\begin{array}{r}99.5 \\
148.5 \\
152 \\
137\end{array}$ & $\begin{array}{r}-89.5 \\
-138.5 \\
-142 \\
-127\end{array}$ & $\begin{array}{l}0 \\
0 \\
0 \\
0\end{array}$ & $\begin{array}{l}0.0 \\
0.0 \\
0.0 \\
0.0\end{array}$ & $\begin{array}{l}0 \\
0 \\
0 \\
0\end{array}$ & & $\begin{array}{r}99.5 \\
148.5 \\
152 \\
137\end{array}$ & $\begin{array}{l}30.3 \\
45.3 \\
46.3 \\
41.8\end{array}$ & $\begin{array}{l}0 \\
0 \\
0 \\
0\end{array}$ & $\begin{array}{l}0 \\
1 \\
0\end{array}$ & $\begin{array}{l}24 \text { * } \\
30 \text { * } \\
37 \text { * }\end{array}$ \\
\hline $\begin{array}{l}\text { T8NR3W17Cb } \\
\text { T8NR3W26 } \\
\text { T8NR3W26Bd } \\
\text { T8NR3W24 }\end{array}$ & $\begin{array}{l}250 \\
251 \\
252 \\
253\end{array}$ & $\begin{array}{l}493393 \\
498485 \\
498514 \\
500047\end{array}$ & $\begin{array}{l}5113436 \\
5110492 \\
5110441 \\
5112151\end{array}$ & $\begin{array}{l}10 \\
20 \\
20 \\
20\end{array}$ & $\begin{array}{r}105 \\
200 \\
35 \\
230\end{array}$ & $\begin{array}{r}-95 \\
-180 \\
-15 \\
-210\end{array}$ & $\begin{array}{r}0 \\
0 \\
0 \\
-188\end{array}$ & $\begin{array}{r}0.0 \\
0.0 \\
0.0 \\
-57.3\end{array}$ & $\begin{array}{l}0 \\
0 \\
0 \\
1\end{array}$ & Grvl & $\begin{array}{r}105 \\
200 \\
35 \\
208\end{array}$ & $\begin{array}{l}32.0 \\
61.0 \\
10.7 \\
63.4\end{array}$ & $\begin{array}{l}0 \\
1 \\
0 \\
0\end{array}$ & & \\
\hline $\begin{array}{l}\text { T8NR2W260 cad } \\
\text { T8NR2W31Cdac } \\
\text { T8NR3W36Baab } \\
\text { T8NR3W36Adb } \\
\text { T8NR3W25Dcbb } \\
\text { T8NR3W25Dcd } \\
\text { T8NR3W25Cdba } \\
\text { T8NR2W34Cd }\end{array}$ & $\begin{array}{l}254 \\
255 \\
256 \\
257 \\
258 \\
259 \\
260 \\
261\end{array}$ & $\begin{array}{l}508281 \\
501418 \\
499882 \\
500524 \\
500052 \\
500350 \\
499788 \\
506040\end{array}$ & $\begin{array}{l}5109811 \\
5108079 \\
5109452 \\
5108964 \\
5109886 \\
5109704 \\
5109858 \\
5108041\end{array}$ & $\begin{array}{l}12 \\
15 \\
10 \\
10 \\
10 \\
10 \\
10 \\
10\end{array}$ & $\begin{array}{r}361 \\
201.5 \\
410 \\
261 \\
353 \\
339 \\
395 \\
111\end{array}$ & $\begin{array}{r}-349 \\
-184.5 \\
-400 \\
-251 \\
-343 \\
-329 \\
-385 \\
-101\end{array}$ & $\begin{array}{r}-153 \\
-179 \\
-295 \\
-197 \\
-302 \\
-289 \\
-317 \\
0\end{array}$ & $\begin{array}{l}-46.6 \\
-54.6 \\
-89.9 \\
-60.0 \\
-92.1 \\
-88.1 \\
-96.6 \\
0.0\end{array}$ & $\begin{array}{l}1 \\
1 \\
1 \\
1 \\
1 \\
1 \\
1 \\
0\end{array}$ & $\begin{array}{l}\text { Grvl } \\
\text { Grvl } \\
\text { Grvl } \\
\text { Grvl } \\
\text { S\&G } \\
\text { S\&G } \\
\text { Grvl }\end{array}$ & $\begin{array}{l}165 \\
194 \\
305 \\
207 \\
312 \\
299 \\
327 \\
111\end{array}$ & $\begin{array}{l}50.3 \\
59.1 \\
93.0 \\
63.1 \\
95.1 \\
91.1 \\
99.7 \\
33.8\end{array}$ & $\begin{array}{l}0 \\
0 \\
0 \\
0 \\
0 \\
0 \\
0 \\
0\end{array}$ & & \\
\hline $\begin{array}{l}\text { TTNR2W36D } \\
\text { TTNR2W360C } \\
\text { T7NR1H31Dd }\end{array}$ & $\begin{array}{l}262 \\
263 \\
264 \\
265\end{array}$ & $\begin{array}{l}509993 \\
509770 \\
511557 \\
511230\end{array}$ & $\begin{array}{l}5098664 \\
5098436 \\
5098434 \\
5099083\end{array}$ & $\begin{array}{l}10 \\
13 \\
32 \\
18\end{array}$ & $\begin{array}{r}331 \\
101.5 \\
115 \\
29\end{array}$ & $\begin{array}{r}-321 \\
-88.5 \\
-83 \\
-11\end{array}$ & $\begin{array}{r}-315 \\
0 \\
-70 \\
0\end{array}$ & $\begin{array}{r}-96.0 \\
0.0 \\
-21.3 \\
0.0\end{array}$ & $\begin{array}{l}1 \\
0 \\
1 \\
0\end{array}$ & $\begin{array}{r}\text { Claystn } \\
\text { S\&G }\end{array}$ & $\begin{array}{r}325 \\
101.5 \\
102 \\
29\end{array}$ & $\begin{array}{r}99.1 \\
30.9 \\
31.1 \\
8.8\end{array}$ & $\begin{array}{l}0 \\
0 \\
0 \\
0\end{array}$ & & \\
\hline $\begin{array}{l}\text { Kalama Coal } \\
\text { Shipment Fac. }\end{array}$ & $\begin{array}{l}266 \\
267 \\
268\end{array}$ & $\begin{array}{l}509813 \\
510192 \\
510571\end{array}$ & $\begin{array}{l}5098666 \\
5098530 \\
5099040\end{array}$ & $\begin{array}{r}9.5 \\
12 \\
10\end{array}$ & $\begin{array}{r}65 \\
71.5 \\
71.5\end{array}$ & $\begin{array}{l}-55.5 \\
-59.5 \\
-61.5\end{array}$ & $\begin{array}{l}0 \\
0 \\
0\end{array}$ & $\begin{array}{l}0.0 \\
0.0 \\
0.0\end{array}$ & $\begin{array}{l}0 \\
0 \\
0\end{array}$ & & $\begin{array}{r}65 \\
71.5 \\
71.5\end{array}$ & $\begin{array}{l}19.8 \\
21.8 \\
21.8\end{array}$ & $\begin{array}{l}0 \\
0 \\
0\end{array}$ & $\begin{array}{l}1 \\
1 \\
1\end{array}$ & $\begin{array}{l}28 \\
52 \\
33\end{array}$ \\
\hline
\end{tabular}


Location

Dow Chemical

Kal ama Wa

\begin{tabular}{|c|c|c|}
\hline 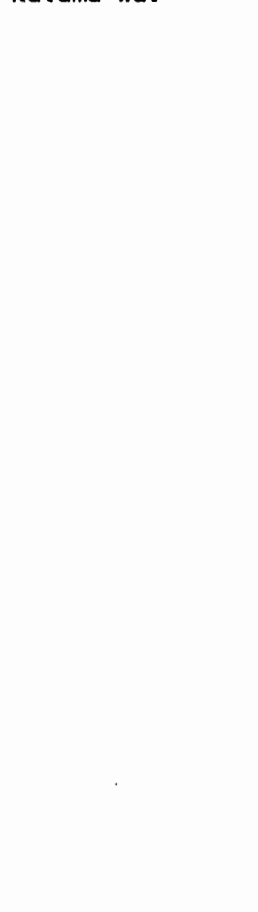 & $\begin{array}{l}271 \\
272 \\
273 \\
274 \\
275 \\
276 \\
277 \\
278 \\
279 \\
280 \\
281 \\
282 \\
283 \\
284 \\
285 \\
286 \\
287 \\
288 \\
289 \\
290 \\
291 \\
292 \\
293 \\
294 \\
295 \\
296 \\
297 \\
298 \\
299\end{array}$ & $\begin{array}{l}511000 \\
510958 \\
511160 \\
510888 \\
510890 \\
511098 \\
511298 \\
510622 \\
510702 \\
510641 \\
510714 \\
510561 \\
510647 \\
510769 \\
510818 \\
510922 \\
510893 \\
511011 \\
511022 \\
511069 \\
510900 \\
511016 \\
511060 \\
510806 \\
509655 \\
509773 \\
509957 \\
510126 \\
510359\end{array}$ \\
\hline $\begin{array}{l}\text { Sand Exploration } \\
\text { Kalama Wa. }\end{array}$ & $\begin{array}{l}300 \\
301 \\
302 \\
303 \\
304 \\
305 \\
306 \\
307 \\
308 \\
309\end{array}$ & $\begin{array}{l}509783 \\
509910 \\
510009 \\
510267 \\
509804 \\
509921 \\
510098 \\
510161 \\
509867 \\
509848\end{array}$ \\
\hline
\end{tabular}

Map ID\# UTM EAST UTM NORTH Surface Hole Hole QalBasal QalBasal GIS Basal Isopach Isopach Ash SPT

Elev ft Depth Ft Base Ft Contactft ContactM Code Lithol Feet Meters Code Min Max

$\begin{array}{rrrrrrrrr}269 & 510586 & 5096664 & 11 & 53.5 & -42.5 & 0 & 0.0 & 0 \\ 270 & 510911 & 5096731 & 9 & 50 & -41 & 0 & 0.0 & 0 \\ 271 & 511000 & 5096817 & 10 & 50 & -40 & 0 & 0.0 & 0 \\ 272 & 510958 & 5096528 & 14 & 52 & -38 & 0 & 0.0 & 0 \\ 273 & 511160 & 5096576 & 10 & 76.5 & -66.5 & 0 & 0.0 & 0 \\ 274 & 510888 & 5096318 & 18 & 50 & -32 & 0 & 0.0 & 0 \\ 275 & 510890 & 5096293 & 18 & 23 & -5 & 0 & 0.0 & 0 \\ 276 & 511098 & 5096244 & 14.5 & 50 & -35.5 & 0 & 0.0 & 0 \\ 277 & 511298 & 5096325 & 12 & 72 & -60 & 0 & 0.0 & 0 \\ 278 & 510622 & 5096549 & 14 & 86 & -72 & 0 & 0.0 & 0 \\ 279 & 510702 & 5096549 & 14 & 86 & -72 & 0 & 0.0 & 0 \\ 280 & 510641 & 5096476 & 20 & 32.5 & -12.5 & 0 & 0.0 & 0 \\ 281 & 510714 & 5096495 & 18 & 32.5 & -14.5 & 0 & 0.0 & 0 \\ 282 & 510561 & 5096585 & 18 & 31.5 & -13.5 & 0 & 0.0 & 0 \\ 283 & 510647 & 5096614 & 14 & 31 & -17 & 0 & 0.0 & 0 \\ 284 & 510769 & 5096386 & 19 & 51 & -32 & 0 & 0.0 & 0 \\ 285 & 510818 & 5096322 & 18.5 & 52 & -33.5 & 0 & 0.0 & 0 \\ 286 & 510922 & 5096206 & 19 & 52 & -33 & 0 & 0.0 & 0 \\ 287 & 510893 & 5096393 & 17 & 50 & -33 & 0 & 0.0 & 0 \\ 288 & 511011 & 5096385 & 13.5 & 52 & -38.5 & 0 & 0.0 & 0 \\ 289 & 511022 & 5096266 & 16.5 & 54 & -37.5 & 0 & 0.0 & 0 \\ 290 & 511069 & 5096338 & 14.5 & 60 & -45.5 & 0 & 0.0 & 0 \\ 291 & 510900 & 5096440 & 13 & 48.5 & -35.5 & 0 & 0.0 & 0 \\ 292 & 511016 & 5096462 & 11.5 & 60 & -48.5 & 0 & 0.0 & 0 \\ 293 & 511060 & 5096508 & 10 & 49 & -39 & 0 & 0.0 & 0 \\ 294 & 510806 & 5096460 & 14.5 & 52 & -37.5 & 0 & 0.0 & 0 \\ 295 & 509655 & 5097711 & -30 & 15 & -45 & 0 & 0.0 & 0 \\ 296 & 509773 & 5097390 & -30 & 16 & -46 & 0 & 0.0 & 0 \\ 297 & 509957 & 5097102 & -30 & 13 & -43 & 0 & 0.0 & 0 \\ 298 & 510126 & 5096902 & -30 & 20 & -50 & 0 & 0.0 & 0 \\ 299 & 510359 & 5096690 & -30 & 14 & -44 & 0 & 0.0 & 0\end{array}$

$\begin{array}{rrr}53.5 & 16.3 & 0 \\ 50 & 15.2 & 0 \\ 50 & 15.2 & 0 \\ 52 & 15.8 & 0 \\ 76.5 & 23.3 & 0 \\ 50 & 15.2 & 0 \\ 23 & 7.0 & 0 \\ 50 & 15.2 & 0 \\ 72 & 21.9 & 0 \\ 86 & 26.2 & 0 \\ 86 & 26.2 & 0 \\ 32.5 & 9.9 & 0 \\ 32.5 & 9.9 & 0 \\ 31.5 & 9.6 & 0 \\ 31 & 9.4 & 0 \\ 51 & 15.5 & 0 \\ 52 & 15.8 & 0 \\ 52 & 15.8 & 0 \\ 50 & 15.2 & 0 \\ 52 & 15.8 & 0 \\ 54 & 16.5 & 0 \\ 60 & 18.3 & 0 \\ 48.5 & 14.8 & 0 \\ 60 & 18.3 & 0 \\ 49 & 14.9 & 0 \\ 52 & 15.8 & 0 \\ 15 & 4.6 & 0 \\ 16 & 4.9 & 0 \\ 13 & 4.0 & 0 \\ 20 & 6.1 & 0 \\ 14 & 4.3 & 0\end{array}$

$\begin{array}{llll}5097606 & -10 & 42 & -52\end{array}$

$\begin{array}{ll}0.0 & 0 \\ 0.0 & 0\end{array}$

$\begin{array}{ll}0.0 & 0 \\ 0.0 & 0\end{array}$

$0.0 \quad 0$

$0.0 \quad 0$

0.00

$0.0 \quad 0$

$0.0 \quad 0$

$0.0 \quad 0$

$\begin{array}{rrr}42 & 12.8 & 0 \\ 33 & 10.1 & 0 \\ 10 & 3.0 & 0 \\ 37 & 11.3 & 0 \\ 49 & 14.9 & 0 \\ 20 & 6.1 & 0 \\ 46 & 14.0 & 0 \\ 40 & 12.2 & 0 \\ 19 & 5.8 & 0 \\ 42 & 12.8 & 0\end{array}$


Hole QalBasal QalBasal GIS

Basal Isopach Isopach Ash SPT Elev Ft Depth Ft Base Ft ContactFt ContactM Code Lithol Feet Meters Code Min Max

Proposed Mill Kalama Ha.

Port of Kalama

Kalama Ha.

South 2 miles

$\begin{array}{rrrrrrrrr}310 & 510188 & 5097140 & -5 & 74.5 & -79.5 & 0 & 0.0 & 0 \\ 311 & 510255 & 5097051 & -0.5 & 71.5 & -72 & 0 & 0.0 & 0 \\ 312 & 510321 & 5096865 & -17 & 72 & -89 & 0 & 0.0 & 0 \\ 313 & 510937 & 5097636 & 9.7 & 15 & -5.3 & 0 & 0.0 & 0 \\ 314 & 510372 & 5097280 & 10.3 & 21 & -10.7 & 0 & 0.0 & 0 \\ 315 & 510389 & 5097624 & 12.9 & 24 & -11.1 & 0 & 0.0 & 0 \\ 316 & 510297 & 5097933 & 8.5 & 15 & -6.5 & 0 & 0.0 & 0 \\ 317 & 510115 & 5098011 & 10.6 & 17 & -6.4 & 0 & 0.0 & 0 \\ 318 & 510384 & 5098093 & 10.2 & 16 & -5.8 & 0 & 0.0 & 0 \\ 319 & 510190 & 5097709 & 9.9 & 16 & -6.1 & 0 & 0.0 & 0 \\ 320 & 510608 & 5097433 & 13.6 & 20 & -6.4 & 0 & 0.0 & 0 \\ 321 & 510584 & 5097658 & 10.3 & 16 & -5.7 & 0 & 0.0 & 0 \\ 322 & 510549 & 5097778 & 10.2 & 16 & -5.8 & 0 & 0.0 & 0 \\ 323 & 511065 & 5097471 & 8.6 & 45 & -36.4 & 0 & 0.0 & 0 \\ 324 & 511001 & 5097313 & 10.9 & 26 & -15.1 & 0 & 0.0 & 0 \\ 325 & 510753 & 5097253 & 10.2 & 20 & -9.8 & 0 & 0.0 & 0 \\ 326 & 510739 & 5096940 & 9.1 & 25 & -15.9 & 0 & 0.0 & 0 \\ 327 & 510484 & 5097072 & 11.4 & 26 & -14.6 & 0 & 0.0 & 0 \\ 328 & 510300 & 5097662 & 9.4 & 10 & -0.6 & 0 & 0.0 & 0 \\ 329 & 510727 & 5097561 & 5.4 & 10 & -4.6 & 0 & 0.0 & 0 \\ 330 & 510584 & 5097565 & 10.8 & 10 & 0.8 & 0 & 0.0 & 0 \\ 331 & 510809 & 5097544 & 11.5 & 17 & -5.5 & 0 & 0.0 & 0 \\ 332 & 510867 & 5097311 & 10 & 50 & -40 & 0 & 0.0 & 0 \\ 333 & 510973 & 5097173 & 10 & 23 & -13 & 0 & 0.0 & 0 \\ 334 & 510376 & 5096788 & 16 & 85 & -69 & 0 & 0.0 & 0 \\ 335 & 510581 & 5097132 & 12 & 18 & -6 & 0 & 0.0 & 0 \\ 336 & 510197 & 5097292 & 10 & 89.5 & -79.5 & 0 & 0.0 & 0 \\ 337 & 510036 & 5096999 & -27.5 & 22.5 & -50 & 0 & 0.0 & 0 \\ 338 & 510140 & 5097090 & -2.5 & 48.5 & -51 & 0 & 0.0 & 0 \\ 339 & 509973 & 5097355 & -2 & 48 & -50 & 0 & 0.0 & 0 \\ 340 & 510122 & 5097295 & -2.5 & 49 & -51.5 & 0 & 0.0 & 0 \\ 341 & 509747 & 5097516 & -23.5 & 26 & -49.5 & 0 & 0.0 & 0 \\ 342 & 511922 & 5094805 & 3.5 & 43.5 & -40 & 0 & 0.0 & 0 \\ 343 & 511962 & 5094699 & 1 & 35.5 & -34.5 & 0 & 0.0 & 0 \\ 344 & 511992 & 5094594 & 4.5 & 39 & -34.5 & 0 & 0.0 & 0 \\ 345 & 511940 & 5094513 & 4 & 31.5 & -27.5 & 0 & 0.0 & 0 \\ 346 & 513243 & 5092026 & 27 & 65 & -38 & -37.5 & -11.4 & 1 \\ 347 & 513202 & 5092095 & 27.5 & 43.5 & -16 & -13.5 & -4.1 & 1 \\ 348 & 513157 & 5092180 & 28 & 68 & -40 & -40 & -12.2 & 1\end{array}$

$\begin{array}{lll}74.5 & 22.7 & 0\end{array}$

$71.5 \quad 21.8 \quad 0$

$72 \quad 21.9$

$15 \quad 4.6 \quad 0$

$21 \quad 6.4$

$24 \quad 7.3$

$15 \quad 4.6$

$17 \quad 5.2$

4.90

$\begin{array}{lll}16 & 4.9 & 0\end{array}$

$\begin{array}{lll}20 & 6.1 & 0\end{array}$

$\begin{array}{lll}16 & 4.9 & 0 \\ 16 & 4.9 & 0\end{array}$

$\begin{array}{lll}45 & 13.7\end{array}$

$\begin{array}{lll}26 & 7.9 & 0\end{array}$

206.9

$25 \quad 7.6$

$10 \quad 3.0$

$10 \quad 3.0$

103.0

$17 \quad 5.2$

$23 \quad 7.0$

$85 \quad 25.9$

$18 \quad 5.5$

$89.5 \quad 27.3$

$22.5 \quad 6.9$

$48.5 \quad 14.8$

$48 \quad 14.6$

$\begin{array}{lll}49 & 14.9 & 0\end{array}$

$\begin{array}{rrr}26 & 7.9 & 0\end{array}$

$\begin{array}{rrr}43.5 & 13.3 & 0 \\ 35.5 & 10.8 & 0 \\ 39 & 11.9 & 0 \\ 31.5 & 9.6 & 0\end{array}$

Bslt $\quad 64.5 \quad 19.7 \quad 0$

Bslt $\quad 40 \quad 12.7 \quad 0$

$\begin{array}{llllll}\text { Bslt } & 68 & 20.7 & 0 & 10 & 24\end{array}$ 


\begin{tabular}{|c|c|c|c|c|c|c|c|c|c|c|c|c|c|c|c|}
\hline & $\begin{array}{l}349 \\
350 \\
351\end{array}$ & $\begin{array}{l}513277 \\
513234 \\
513191\end{array}$ & $\begin{array}{l}5092045 \\
5092110 \\
5092198\end{array}$ & $\begin{array}{r}29 \\
30.5 \\
29\end{array}$ & $\begin{array}{r}45.5 \\
17.5 \\
70\end{array}$ & $\begin{array}{r}-16.5 \\
13 \\
-41\end{array}$ & $\begin{array}{r}-16.5 \\
15.5 \\
-21\end{array}$ & $\begin{array}{r}-5.0 \\
4.7 \\
-6.3\end{array}$ & $\begin{array}{l}1 \\
1 \\
1\end{array}$ & $\begin{array}{l}\text { Bslt } \\
\text { Bslt } \\
\text { Bslt }\end{array}$ & $\begin{array}{r}45.5 \\
15 \\
50\end{array}$ & $\begin{array}{r}13.9 \\
4.6 \\
15.2\end{array}$ & $\begin{array}{l}0 \\
0 \\
0\end{array}$ & 18 & 24 \\
\hline $\begin{array}{l}\text { Virginia Chem Co } \\
\text { Kalama Ha. }\end{array}$ & $\begin{array}{l}352 \\
353 \\
354 \\
355 \\
356 \\
357 \\
358 \\
359\end{array}$ & $\begin{array}{l}512372 \\
512272 \\
512225 \\
512336 \\
512601 \\
512688 \\
512783 \\
512880\end{array}$ & $\begin{array}{l}5093244 \\
5093365 \\
5093497 \\
5093332 \\
5092889 \\
5092601 \\
5092658 \\
5092644\end{array}$ & $\begin{array}{r}29 \\
8.2 \\
32 \\
36.8 \\
21.3 \\
21.3 \\
27.1 \\
28.4\end{array}$ & $\begin{array}{r}85 \\
112 \\
49 \\
44 \\
56.3 \\
37 \\
58 \\
69\end{array}$ & $\begin{array}{r}-56 \\
-103.8 \\
-17 \\
-7.2 \\
-35 \\
-15.7 \\
-30.9 \\
-40.6\end{array}$ & $\begin{array}{r}-51 \\
-98 \\
-13 \\
4 \\
4 \\
-33.5 \\
-14 \\
-29 \\
0\end{array}$ & $\begin{array}{r}-15.5 \\
-29.9 \\
-4.0 \\
1.2 \\
-10.2 \\
-4.3 \\
-8.8 \\
0.0\end{array}$ & $\begin{array}{l}1 \\
1 \\
1 \\
1 \\
1 \\
1 \\
1 \\
0\end{array}$ & $\begin{array}{l}\text { Bslt } \\
\text { Bslt } \\
\text { Bslt } \\
\text { Bslt } \\
\text { Bslt } \\
\text { Bslt } \\
\text { Bslt }\end{array}$ & $\begin{array}{r}80 \\
106.2 \\
45 \\
32.8 \\
54.8 \\
35.3 \\
56.1 \\
69\end{array}$ & $\begin{array}{l}24.4 \\
32.4 \\
13.7 \\
10.0 \\
16.7 \\
10.8 \\
17.1 \\
21.0\end{array}$ & $\begin{array}{l}0 \\
0 \\
0 \\
0 \\
0 \\
0 \\
0 \\
0\end{array}$ & $\begin{array}{l}2 \\
4 \\
4 \\
4 \\
5\end{array}$ & $\begin{array}{l}26 \text { * } \\
13 \text { * } \\
12 \text { * } \\
17 \text { * }\end{array}$ \\
\hline $\begin{array}{l}\text { Grain Terminal } \\
\text { Kalama Wa. }\end{array}$ & $\begin{array}{l}360 \\
361 \\
362 \\
363 \\
364 \\
365 \\
366 \\
367 \\
368 \\
369 \\
370 \\
371 \\
372 \\
373 \\
374 \\
375 \\
376 \\
377 \\
378 \\
379 \\
380\end{array}$ & $\begin{array}{l}513022 \\
512943 \\
512861 \\
512986 \\
512934 \\
513119 \\
512950 \\
512789 \\
512886 \\
513073 \\
512958 \\
512684 \\
512767 \\
512862 \\
512950 \\
512981 \\
513029 \\
512993 \\
513019 \\
513034 \\
512904\end{array}$ & $\begin{array}{l}5091956 \\
5092133 \\
5092308 \\
5092060 \\
5092242 \\
5092038 \\
5092312 \\
5092441 \\
5092484 \\
5092185 \\
5092389 \\
5092400 \\
5092259 \\
5092090 \\
5091914 \\
5092136 \\
5092046 \\
5092170 \\
5092123 \\
5092085 \\
5092311\end{array}$ & $\begin{array}{r}12 \\
9.5 \\
12.5 \\
10.5 \\
14 \\
18 \\
25 \\
11.1 \\
26.4 \\
20 \\
25 \\
-32 \\
-33 \\
-42 \\
-43 \\
12 \\
12 \\
12 \\
16 \\
15 \\
26\end{array}$ & $\begin{array}{r}110 \\
97 \\
65 \\
102 \\
79 \\
78 \\
68 \\
39 \\
26 \\
65 \\
49.5 \\
43 \\
44 \\
33 \\
34 \\
88 \\
99 \\
77 \\
87 \\
91 \\
71\end{array}$ & $\begin{array}{r}-98 \\
-87.5 \\
-52.5 \\
-91.5 \\
-65 \\
-60 \\
-43 \\
-27.9 \\
0.4 \\
-45 \\
-24.5 \\
-75 \\
-77 \\
-75 \\
-77 \\
-76 \\
-87 \\
-65 \\
-71 \\
-76 \\
-45\end{array}$ & $\begin{array}{r}-94 \\
-73.5 \\
-50.5 \\
-71.5 \\
-58 \\
-59 \\
-42 \\
-27.9 \\
2.4 \\
-44 \\
-23.5 \\
0 \\
0 \\
0 \\
0 \\
-67 \\
-69 \\
-63 \\
-60 \\
-64 \\
0\end{array}$ & $\begin{array}{r}-28.7 \\
-22.4 \\
-15.4 \\
-21.8 \\
-17.7 \\
-18.0 \\
-12.8 \\
-8.5 \\
0.7 \\
-13.4 \\
-7.2 \\
0.0 \\
0.0 \\
0.0 \\
0.0 \\
-20.4 \\
-21.0 \\
-19.2 \\
-18.3 \\
-19.5 \\
0.0\end{array}$ & $\begin{array}{l}1 \\
1 \\
1 \\
1 \\
1 \\
1 \\
1 \\
1 \\
1 \\
1 \\
1 \\
0 \\
0 \\
0 \\
0 \\
1 \\
1 \\
1 \\
1 \\
1 \\
0\end{array}$ & $\begin{array}{l}\text { Grvl } \\
\text { Grvl } \\
\text { Rock } \\
\text { Grvl } \\
\text { Grvl } \\
\text { Rock } \\
\text { Rock } \\
\text { Rock } \\
\text { Rock } \\
\text { Rock } \\
\text { Rock }\end{array}$ & $\begin{array}{r}106 \\
83 \\
63 \\
82 \\
72 \\
77 \\
67 \\
39 \\
24 \\
64 \\
48.5 \\
43 \\
44 \\
33 \\
34 \\
79 \\
81 \\
75 \\
76 \\
79 \\
71\end{array}$ & $\begin{array}{l}32.3 \\
25.3 \\
19.2 \\
25.0 \\
21.9 \\
23.5 \\
20.4 \\
11.9 \\
7.3 \\
19.5 \\
14.8 \\
13.1 \\
13.4 \\
10.1 \\
10.4 \\
24.1 \\
24.7 \\
22.9 \\
23.2 \\
24.1 \\
21.6\end{array}$ & $\begin{array}{l}0 \\
0 \\
0 \\
0 \\
0 \\
0 \\
0 \\
0 \\
0 \\
0 \\
0 \\
0 \\
0 \\
0 \\
0 \\
0 \\
0 \\
0 \\
0 \\
0 \\
0\end{array}$ & & \\
\hline $\begin{array}{l}\text { Non Developed } \\
\text { Industrial Site }\end{array}$ & $\begin{array}{l}381 \\
382 \\
383 \\
384 \\
385 \\
386 \\
387\end{array}$ & $\begin{array}{l}519213 \\
519221 \\
519169 \\
519178 \\
513690 \\
513596 \\
513670\end{array}$ & $\begin{array}{l}5083895 \\
5083816 \\
5083866 \\
5083783 \\
5090945 \\
5091045 \\
5091095\end{array}$ & $\begin{array}{r}-2.5 \\
-3.5 \\
-2.5 \\
-3 \\
45 \\
30 \\
14\end{array}$ & $\begin{array}{r}80.5 \\
80 \\
90.5 \\
80 \\
120.8 \\
105.8 \\
86\end{array}$ & $\begin{array}{r}-83 \\
-83.5 \\
-93 \\
-83 \\
-75.8 \\
-75.8 \\
-72\end{array}$ & $\begin{array}{l}0 \\
0 \\
0 \\
0 \\
45 \\
30 \\
14\end{array}$ & $\begin{array}{r}0.0 \\
0.0 \\
0.0 \\
0.0 \\
13.7 \\
9.1 \\
4.3\end{array}$ & $\begin{array}{l}0 \\
0 \\
0 \\
0 \\
1 \\
1 \\
1\end{array}$ & $\begin{array}{l}\text { Rock } \\
\text { Rock } \\
\text { Rock }\end{array}$ & $\begin{array}{r}80.5 \\
80 \\
90.5 \\
80 \\
120.8 \\
105.8 \\
86\end{array}$ & $\begin{array}{l}24.5 \\
24.4 \\
27.6 \\
24.4 \\
36.8 \\
32.2 \\
26.2\end{array}$ & $\begin{array}{l}0 \\
0 \\
0 \\
0 \\
0 \\
0 \\
0\end{array}$ & $\begin{array}{l}0 \\
2 \\
0\end{array}$ & $\begin{array}{l}21 \text { * } \\
22 \text { * } \\
17 \text { * }\end{array}$ \\
\hline
\end{tabular}


Map ID\# UTM EAST UTM NORTH Surface Hole Hole QalBasal QalBasal GIS Basal Isopach Isopach Ash SPT

Elev Ft Depth Ft Base Ft Contactft ContactM Code Lithol Feet Meters Code Min Max

T5NR1W10

T5NR1W11Bd

T5NR1W15Cd

T5NR 1 H14Cb

T5NR1H148d

T5NR 1W14Bdda

TSNR1W14AB

T5NR 1H13BC

T5NR1H13Bb

T5NR 1H13CC

T5NR 1H16CC

T5NR1W8A

Fertilizer Plant

st. Helens Or.

Boise Cascade

St. Helens Or.

Lewis River site

388

516303

5085707

10

$\begin{array}{ll}389 & 517212 \\ 390 & 515623\end{array}$

$\begin{array}{ll}390 & 515623 \\ 391 & 517465\end{array}$

5086350

5084604

5084433

$517080 \quad 5084840$

5084778

$518685 \quad 5084836$

5085255

$518583 \quad 5084050$

$399 \quad 513302 \quad 5087034$

$\begin{array}{rr}43 & -33 \\ 198 & -190 \\ 202 & -192 \\ 51 & -36 \\ 40 & -30 \\ 38 & -28 \\ 30 & -20 \\ 51.5 & -41.5 \\ 56 & -46 \\ 45 & -25 \\ 160 & -145 \\ 70 & -55\end{array}$

$\begin{array}{rrr}0 & 0.0 & 0 \\ 0 & 0.0 & 0 \\ -136 & -41.5 & 1 \\ 0 & 0.0 & 0 \\ 0 & 0.0 & 0 \\ 0 & 0.0 & 0 \\ 0 & 0.0 & 0 \\ 0 & 0.0 & 0 \\ 0 & 0.0 & 0 \\ 0 & 0.0 & 0 \\ -88 & -26.8 & 1 \\ 0 & 0.0 & 0\end{array}$

$\begin{array}{lrrr} & 43 & 13.1 & 0 \\ \text { G\&Cl ay } & 198 & 60.4 & 0 \\ & 146 & 44.5 & 0 \\ & 51 & 15.5 & 0 \\ & 40 & 12.2 & 0 \\ & 38 & 11.6 & 0 \\ & 30 & 9.1 & 0 \\ & 51.5 & 15.7 & 0 \\ & 56 & 17.1 & 0 \\ \text { S\&G } & 45 & 13.7 & 0 \\ & 103 & 31.4 & 0 \\ & 70 & 21.3 & 0 \\ & 61 & 18.6 & 0 \\ & 55 & 16.8 & 1 \\ & & & \\ & 104.7 & 31.9 & 1 \\ & 116.6 & 35.5 & 0 \\ & 94.4 & 28.8 & 1 \\ & & & \\ & 72.5 & 22.1 & 0 \\ & 53.5 & 16.3 & 0 \\ 94.4 & 28.8 & 1\end{array}$

Campbell Lake

site

T4NR1W14Ba

T4NR 1W17Bdd

T3NR1W7

T3NR1H5

T3NR1H19

T3NR1H18

T3NR TH23

T3NR1H26

T3NR 1W30

T3NR1W3OCC

T3NRIWSICd

T3NR1W31Bd

T3NR1W32

T3NR TH33BC

$400 \quad 514351$

5084293

0.7
-12.3

$\begin{array}{ll}61 & -60.3 \\ 55 & -67.3\end{array}$

$0.0 \quad 0$

$\begin{array}{rrr}23 & 104.7 & -81.7 \\ 23.5 & 116.6 & -93.1 \\ 23.5 & 94.4 & -70.9\end{array}$

$402 \quad 515389$

403
404 515373

5076933

5076893

$0.0 \quad 0$

$\begin{array}{ll}0.0 & 0 \\ 0.0 & 0\end{array}$

$405 \quad 518155$

5077917

$\begin{array}{ll}72.5 & -62.5\end{array}$

406
$407 \quad 518401$

5077927

10

$\begin{array}{ll}72.5 & -62.5 \\ 53.5 & -43.5\end{array}$

$94.4 \quad-84.4$

0.00

$\begin{array}{ll}0.0 & 0 \\ 0.0 & 0\end{array}$

$408 \quad 5187$

5068119

20

$\begin{array}{rrr}20 & 80 & -60 \\ 15.5 & 77.5 & -62\end{array}$

$0.0 \quad 0$

$\begin{array}{lll}410 & 517682 & 5075614 \\ 411 & 512622 & 5074826\end{array}$

$411 \quad 512622$

5074826

5066872

$413 \quad 512837 \quad 5068577$

$414 \quad 514120 \quad 5068847$

$\begin{array}{lll}415 & 510784 \quad 5064070\end{array}$

$\begin{array}{lll}416 & 511489 & 5065164\end{array}$

$417 \quad 517655 \quad 5063725$

$418 \quad 517615 \quad 5061995$

$419 \quad 511207 \quad 5062195$

$420 \quad 510654 \quad 5061469$

$421 \quad 511063 \quad 5059884$

$\begin{array}{lll}422 & 511002 & 5060707\end{array}$

$\begin{array}{lll}423 & 512758 & 5060307\end{array}$

$424 \quad 513848$

5060307
5060689

$80 \quad 24.4 \quad 0$

$\begin{array}{rrrrr}321 & -321 & -82 & -25.0 & 1 \\ 372 & -344 & 1 & 0.3 & 1 \\ 60 & -40 & 14 & 4.3 & 1 \\ 92 & -72 & 5 & 1.5 & 1 \\ 43 & -28 & 0 & 0.0 & 0 \\ 120 & -110 & -88 & -26.8 & 1 \\ 119 & -109 & -63 & -19.2 & 1 \\ 151 & -141 & -138 & -42.1 & 1 \\ 169 & -157 & -135 & -41.1 & 1 \\ 127 & -117 & -114 & -34.7 & 1 \\ 127 & -107 & -107 & -32.6 & 1 \\ 120 & -110 & -102 & -31.1 & 1 \\ 83 & -73 & 0 & 0.0 & 0 \\ 80 & -70 & -25 & -7.6 & 1 \\ 80 & -70 & -33 & -10.1 & 1\end{array}$

$\begin{array}{rrrr}\text { Grvl } & 82 & 25.0 & 0 \\ \text { Bslt } & 27 & 8.2 & 0 \\ \text { Grvl } & 6 & 1.8 & 0 \\ \text { Grvl } & 15 & 4.6 & 0 \\ & 43 & 13.1 & 0 \\ \text { Tt } & 98 & 29.9 & 0 \\ \text { S\&G } & 73 & 22.3 & 0 \\ \text { Grvl } & 148 & 45.1 & 0 \\ \text { Tt } & 147 & 44.8 & 1 \\ \text { Grvl } & 124 & 37.8 & 0 \\ \text { S\&G } & 127 & 38.7 & 0 \\ \text { S\&G } & 112 & 34.1 & 0 \\ & 83 & 25.3 & 0 \\ \text { Grvl } & 35 & 10.7 & 0 \\ \text { Grvl } & 43 & 13.1 & 0\end{array}$


Elev Ft Depth Ft Base Ft Contactft ContactM Code Lithol feet Meters Code Min Max

T3NR1W34

T3NR1H35CC

T2NR1W6B

T2NR 1 H6AB

T2NR 1H2AC

T2NR1W6Da

T2NR1H2Bd

T2NR1H2Bb

T2NRIH11CC

T2NR1H13CC

T2NR1H14

T2NR1H15

T2NR1H1680

T2NR1H16BC

T2NR1H16Bb

T2NR1H16Cd

T2NR 1H17Cad

T2NRIHITAC

T2NR1H17AB

T2NR1H1TDa

T2NR1H1TDC

T2NR TH17Bd

NHTL Sauvie Ist.

T2NR 1W7Ba

T2NR1H7Ca

T2NR1W7AC

T2NR1WBCd

T2NR 1 H8CC

T2NR 1 H8Cb

T2NR 1W9Ca

T3NR1W25CB

T3NR1H25DCb

T3NR1E18BC

T3NR1E19A(H1/2)

T2NR1E28Ba

T2NR1E7BCb

T2NR1E7Cb6

T2NRIE9Cad

T2NR1E9BC

T2NR1E16CC

$\begin{array}{lll}425 & 516233 & 5060271 \\ 426 & 517168 & 5060060 \\ 427 & 510953 & 5059464 \\ 428 & 511344 & 5059488 \\ 429 & 511395 & 5059076 \\ 430 & 511794 & 5058687 \\ 431 & 517315 & 5059129 \\ 432 & 517088 & 5059390 \\ 433 & 517040 & 5056686 \\ 434 & 518477 & 5055048 \\ 435 & 517395 & 5055733 \\ 436 & 516031 & 5055774 \\ 437 & 514201 & 5055787 \\ 438 & 513794 & 5055846 \\ 439 & 513801 & 5056173 \\ 440 & 513939 & 5055183 \\ 441 & 512740 & 5055406 \\ 442 & 513018 & 5055886 \\ 443 & 512973 & 5056264 \\ 444 & 513448 & 5055455 \\ 445 & 513425 & 5055090 \\ 446 & 512689 & 5055743 \\ 447 & 510640 & 5058142 \\ 448 & 511064 & 5057961 \\ 449 & 511180 & 5057158 \\ 450 & 511403 & 5057507 \\ 451 & 512555 & 5056651 \\ 452 & 512153 & 5056669 \\ 453 & 512200 & 5057104 \\ 454 & 514198 & 5057082 \\ 455 & 514987 & 5057523 \\ 456 & 519077 & 5061918 \\ 457 & 519542 & 5061649 \\ 458 & 520176 & 5063978 \\ 459 & 521026 & 5064156 \\ 460 & 523585 & 5053159 \\ 461 & 520077 & 5057684 \\ 462 & 520110 & 5057328 \\ 463 & 523707 & 5057131 \\ 464 & 523552 & 5057615 \\ 465 & 523416 & 5055243\end{array}$

$\begin{array}{rrrrrr}20 & 100 & -80 & -70 & -21.3 & 1 \\ 20 & 220 & -200 & -156 & -47.5 & 1 \\ 10 & 110 & -100 & 0 & 0.0 & 0 \\ 20 & 157 & -137 & -126 & -38.4 & 1 \\ 20 & 45 & -25 & -11 & -3.4 & 1 \\ 20 & 55 & -35 & -29 & -8.8 & 1 \\ 20 & 247 & -227 & -220 & -67.1 & 1 \\ 20 & 212 & -192 & -181 & -55.2 & 1 \\ 20 & 232 & -212 & -181 & -55.2 & 1 \\ 30 & 196 & -166 & -165 & -50.3 & 1 \\ 20 & 257 & -237 & -169 & -51.5 & 1 \\ 10 & 155 & -145 & -135 & -41.1 & 1 \\ 40 & 81 & -41 & -33 & -10.1 & 1 \\ 30 & 100 & -70 & -46 & -14.0 & 1 \\ 20 & 98 & -78 & -66 & -20.1 & 1 \\ 50 & 101 & -51 & -50 & -15.2 & 1 \\ 30 & 185 & -155 & -150 & -45.7 & 1 \\ 48 & 85 & -37 & -26 & -7.9 & 1 \\ 20 & 104 & -84 & -34 & -10.4 & 1 \\ 30 & 72 & -42 & -37 & -11.3 & 1 \\ 30 & 85 & -55 & -55 & -16.8 & 1 \\ 30 & 107 & -77 & -71 & -21.6 & 1 \\ & & & & & \\ 10 & 165 & -155 & -155 & -47.2 & 1 \\ 40 & 94 & -54 & -51 & -15.5 & 1 \\ 20 & 100 & -80 & -71 & -21.6 & 1 \\ 30 & 97 & -67 & -64 & -19.5 & 1 \\ 40 & 91 & -51 & -38 & -11.6 & 1 \\ 50 & 106 & -56 & -24 & -7.3 & 1 \\ 30 & 86 & -56 & -45 & -13.7 & 1 \\ 15 & 112 & -97 & -87 & -26.5 & 1 \\ 15 & 98 & -83 & -79 & -24.1 & 1 \\ 10 & 293 & -283 & -217 & -66.1 & 1 \\ 10 & 460 & -450 & -213 & -64.9 & 1 \\ 10 & 78 & -68 & -53 & -16.2 & 1 \\ 29.5 & 260 & -230.5 & -44.5 & -13.6 & 1 \\ 30 & 407 & -377 & -108 & -32.9 & 1 \\ 10 & 214 & -204 & -185 & -56.4 & 1 \\ 20 & 176 & -156 & -148 & -45.1 & 1 \\ 26 & 120 & -94 & -62 & -18.9 & 1 \\ 20 & 76 & -56 & 0 & 0.0 & 0 \\ 25 & 70 & -45 & -14 & -4.3 & 1\end{array}$

$\begin{array}{rrrl}\text { S\&G } & 90 & 27.4 & 0 \\ \text { Grvl } & 176 & 53.6 & 0 \\ & 110 & 33.5 & 0 \\ \text { S\&G } & 146 & 44.5 & 0 \\ \text { S\&G } & 31 & 9.4 & 0 \\ \text { S\&G } & 49 & 14.9 & 0 \\ \text { Grvl } & 240 & 73.2 & 0 \\ \text { S\&G } & 201 & 61.3 & 0 \\ \text { Grvl } & 201 & 61.3 & 0 \\ \text { Bouldr } & 195 & 59.4 & 0 \\ \text { Grvl } & 189 & 57.6 & 0 \\ \text { Grvl } & 145 & 44.2 & 0 \\ \text { S\&G } & 73 & 22.3 & 0 \\ \text { S\&G\&C } & 76 & 23.2 & 0 \\ \text { S\&G } & 86 & 26.2 & 0 \\ \text { S\&G } & 100 & 30.5 & 0 \\ \text { Grvl } & 180 & 54.9 & 0 \\ \text { S\&G } & 74 & 22.6 & 0 \\ \text { Grvl } & 54 & 16.5 & 0 \\ \text { S\&G } & 67 & 20.4 & 0 \\ \text { Grvl } & 85 & 25.9 & 0 \\ \text { S\&G } & 101 & 30.8 & 0 \\ & & & \\ \text { Grvl } & 165 & 50.3 & 0 \\ \text { Grvl } & 91 & 27.7 & 0 \\ \text { Grvl } & 91 & 27.7 & 0 \\ \text { Grvl } & 94 & 28.7 & 0 \\ \text { Grvl } & 78 & 23.8 & 0 \\ \text { Grvl } & 74 & 22.6 & 0 \\ \text { Grvl } & 75 & 22.9 & 0 \\ \text { Tt } & 102 & 31.1 & 0 \\ \text { Grvl } & 94 & 28.7 & 0 \\ \text { Grvl } & 227 & 69.2 & 0 \\ \text { Grvl } & 223 & 68.0 & 0 \\ \text { Tt } & 63 & 19.2 & 0 \\ \text { Tt } & 74 & 22.6 & 0 \\ \text { Tt } & 138 & 42.1 & 0 \\ \text { Grvl } & 195 & 59.4 & 0 \\ \text { S\&G } & 168 & 51.2 & 0 \\ \text { Tt } & 88 & 26.8 & 0 \\ \text { S\&G } & 76 & 23.2 & 0 \\ & 39 & 11.9 & 0 \\ \text { SrV } & & \end{array}$


Map ID\# UTM EAST UTM NORTH Surface Hole Hole QalBasal QalBasal GIS Basal Isopach Isopach Ash SPT Elev Ft Depth Ft Base Ft Contactft ContactM Code Lithol Feet Meters Code Min Max

T2NR1E16Bad

T2NR1E36Ada

Smith \& Bybee

Lakes

Dutch Cones

Buffalo Elec \#6

T2NR1W21Cc

T2NR1W21Bd

T2NR 1W22BC

T2NR1W22

T2NR1W27Bb

T2NR1W27C

T2NR1H28

ODOT

1205 Bridge

$\begin{array}{lll}466 & 523991 & 5056266 \\ 467 & 529579 & 5051212 \\ 468 & 521511 & 5051971 \\ 469 & 521747 & 5051786 \\ 470 & 520480 & 5052090 \\ 471 & 521109 & 5052114 \\ 472 & 521257 & 5051808\end{array}$

35

$\begin{array}{lll}473 & 527109 & 5051175 \\ 474 & 527223 & 5051486\end{array}$

$\begin{array}{lll}475 & 513840 & 5053522 \\ 476 & 514251 & 5054308 \\ 477 & 515461 & 5054282 \\ 478 & 516027 & 5054047 \\ 479 & 515403 & 5053037 \\ 480 & 515627 & 5052121 \\ 481 & 515499 & 5051927\end{array}$

$\begin{array}{lll}482 & 535044 \quad 5050157\end{array}$

483

$484 \quad 535040$

$485 \quad 535070 \quad 5050049$

$486 \quad 535076 \quad 5049941$

$487 \quad 535068 \quad 5049909$

$\begin{array}{lll}488 & 535094 \quad 5049836\end{array}$

$\begin{array}{lll}489 & 535080 & 5049814\end{array}$

$\begin{array}{lll}490 & 535079 \quad 5049749\end{array}$

$491535106 \quad 5049745$

$492 \quad 535081 \quad 5049689$

$493 \quad 535112 \quad 5049683$

$494 \quad 535090 \quad 5049623$

$495 \quad 535114 \quad 5049616$

$496 \quad 535103 \quad 5049525$

$535127 \quad 5049520$

$535116 \quad 5049437$

$535143 \quad 5049423$

$535136 \quad 5049354$

$535169 \quad 5049346$

$535172 \quad 5049212$

$535213 \quad 5049195$

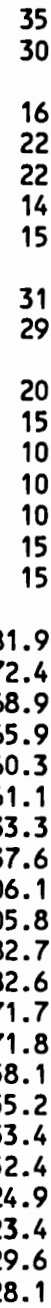

$\begin{array}{rrrrr}211 & -176 & -8 & -2.4 & 1 \\ 260 & -230 & 28 & 8.5 & 1 \\ 119 & -103 & -103 & -31.4 & 1 \\ 114 & -92 & -92 & -28.0 & 1 \\ 89 & -67 & -65 & -19.8 & 1 \\ 88 & -74 & -72 & -21.9 & 1 \\ 84 & -69 & -68 & -20.7 & 1 \\ 168 & -137 & & & \\ 160 & -131 & 20 & 1.5 & 1 \\ & & & 6.1 & 1 \\ 200 & -180 & -176 & -53.6 & 1 \\ 86 & -71 & -60 & -18.3 & 1 \\ 205 & -195 & -176 & -53.6 & 1 \\ 207 & -197 & -193 & -58.8 & 1 \\ 198 & -188 & -182 & -55.5 & 1 \\ 195 & -180 & -170 & -51.8 & 1 \\ 202 & -187 & -170 & -51.8 & 1 \\ & & & & \\ 87.5 & 94.4 & 181.9 & 55.4 & 1 \\ 131.5 & 40.9 & 172.4 & 52.5 & 1 \\ 127 & 41.9 & 168.9 & 51.5 & 1 \\ 111 & 54.9 & 165.9 & 50.6 & 1 \\ 61.5 & 98.8 & 160.3 & 48.9 & 1 \\ 76 & 85.1 & 161.1 & 49.1 & 1 \\ 96 & 37.3 & 133.3 & 40.6 & 1 \\ 81 & 56.6 & 137.6 & 41.9 & 1 \\ 61 & 45.1 & 106.1 & 32.3 & 1 \\ 60 & 45.8 & 105.8 & 32.2 & 1 \\ 80 & 2.7 & 82.7 & 25.2 & 1 \\ 82 & 0.6 & 82.6 & 25.2 & 1 \\ 80 & -8.3 & 71.7 & 21.9 & 1 \\ 62 & 9.8 & 71.8 & 21.9 & 1 \\ 60 & -1.9 & 58.1 & 17.7 & 1 \\ 67 & -11.8 & 55.2 & 16.8 & 1 \\ 60 & -6.6 & 53.4 & 16.3 & 1 \\ 65 & -12.6 & 52.4 & 16.0 & 1 \\ 78 & -53.1 & 12.9 & 3.9 & 1 \\ 81 & -57.6 & 11.4 & 3.5 & 1 \\ 79 & -108.6 & -32.1 & -9.8 & 1 \\ 73.6 & -101.7 & -31.1 & -9.5 & 1\end{array}$

$\begin{array}{rrrr}\text { Grvl } & 43 & 13.1 & 0 \\ \text { S\&G } & 2 & 0.6 & 0 \\ \text { Grvl } & 119 & 36.3 & 0 \\ \text { Grvl } & 114 & 34.7 & 0 \\ \text { Grvl } & 87 & 26.5 & 0 \\ \text { Grvl } & 86 & 26.2 & 0 \\ \text { Grvl } & 83 & 25.3 & 0 \\ & & & \\ \text { Grvl } & 26 & 7.9 & 0 \\ \text { Grvl } & 9 & 2.7 & 0 \\ & & & \\ \text { Grvl } & 196 & 59.7 & 0 \\ \text { S\&G } & 75 & 22.9 & 0 \\ \text { Grvl } & 186 & 56.7 & 0 \\ \text { S\&G } & 203 & 61.9 & 0 \\ \text { S\&G } & 192 & 58.5 & 0 \\ \text { S\&G } & 185 & 56.4 & 0 \\ \text { Grvl } & 185 & 56.4 & 0 \\ & & & \\ \text { S\&G } & 0 & 0.0 & 0 \\ \text { Qff } & 0 & 0.0 & 0 \\ \text { Qff } & 0 & 0.0 & 0 \\ \text { Grvl } & 0 & 0.0 & 0 \\ \text { Grvl } & 0 & 0.0 & 0 \\ \text { Grvl } & 0 & 0.0 & 0 \\ \text { Qff } & 0 & 0.0 & 0 \\ \text { S\&G } & 0 & 0.0 & 0 \\ \text { Qff } & 0 & 0.0 & 0 \\ \text { Tt } & 0 & 0.0 & 0 \\ \text { Tt } & 0 & 0.0 & 0 \\ \text { Tt } & 0 & 0.0 & 0 \\ \text { Tt } & 0 & 0.0 & 0 \\ \text { Qfc } & 0 & 0.0 & 0 \\ \text { QfC } & 0 & 0.0 & 0 \\ \text { Tt } & 0 & 0.0 & 0 \\ \text { Qfc } & 0 & 0.0 & 0 \\ \text { Qfc } & 0 & 0.0 & 0 \\ \text { Tt } & 12 & 3.7 & 0 \\ \text { Tt } & 12 & 3.7 & 0 \\ \text { Qfc } & 2.5 & 0.8 & 0 \\ \text { Qfc } & 3 & 0.9 & 0 \\ & & & \end{array}$



Elev Ft Depth Ft Base Ft Contactft ContactM Code Lithol Feet Meters Code Min Max

Vancouver

East Side

Treatment

Plant

Smith \& Bybee

Dutch Cones

2nd project

$\begin{array}{rrr}535228 & 5049036 & -22 \\ 535262 & 5049024 & -21.1 \\ 535298 & 5048887 & -11.5 \\ 535336 & 5048875 & -10.6 \\ 535373 & 5048769 & -10.5 \\ 535411 & 5048685 & -5.5 \\ 535447 & 5048593 & -2.5 \\ 535494 & 5048497 & -2.5 \\ 535560 & 5048401 & -2.7 \\ 535614 & 5048261 & 12.4 \\ 535656 & 5048116 & 15 \\ 535699 & 5048011 & 12.5 \\ 535756 & 5047865 & 2 \\ 535768 & 5047738 & 20.8 \\ 535799 & 5047659 & 24.8 \\ 535786 & 5047609 & 21.8 \\ 535807 & 5047443 & 21.8 \\ 535814 & 5047284 & 22.3 \\ 535793 & 5047175 & 18.5 \\ 535737 & 5047093 & 28.8 \\ 535737 & 5047055 & 1.9 \\ 535696 & 5047018 & 3.5 \\ 535702 & 5046971 & 3.2 \\ 535685 & 5046929 & 1.3 \\ 535655 & 5046863 & -0.1 \\ 535611 & 5046793 & -8.6 \\ 535573 & 5046725 & -6 \\ 535437 & 5046694 & 4.8 \\ 535506 & 5046639 & 2.9 \\ 535309 & 5046606 & 24 \\ 535403 & 5046547 & 25 \\ 535459 & 5046506 & 26 \\ 530408 & 5050963 & 34 \\ 530446 & 5050940 & 31 \\ 530394 & 5050934 & 36 \\ 530383 & 5050906 & 33 \\ 530436 & 5050893 & 29 \\ & & \\ 521501 & 5051518 & 20 \\ 521231 & 5051212 & 23 \\ 520228 & 5052651 & 23 \\ & & \end{array}$

$\begin{array}{rrrrr}71 & -93 & -80 & -24.4 & 1 \\ 104 & -125.1 & -78.1 & -23.8 & 1 \\ 110 & -121.5 & -80 & -24.4 & 1 \\ 87 & -97.6 & -89.6 & -27.3 & 1 \\ 151 & -161.5 & -91 & -27.7 & 1 \\ 158 & -163.5 & -92.5 & -28.2 & 1 \\ 89.5 & -92 & -91.5 & -27.9 & 1 \\ 159 & -161.5 & -92.5 & -28.2 & 1 \\ 131 & -133.7 & -101.2 & -30.8 & 1 \\ 120 & -107.6 & -95.6 & -29.1 & 1 \\ 175.5 & -160.5 & -104 & -31.7 & 1 \\ 169.5 & -157 & -104.5 & -31.9 & 1 \\ 180 & -178 & -107 & -32.6 & 1 \\ 136.5 & -115.7 & -98.2 & -29.9 & 1 \\ 178 & -153.2 & -102.2 & -31.2 & 1 \\ 130 & -108.2 & -108.2 & -33.0 & 1 \\ 133 & -111.2 & -106.2 & -32.4 & 1 \\ 135.8 & -113.5 & -107.7 & -32.8 & 1 \\ 130 & -111.5 & -101.5 & -30.9 & 1 \\ 141 & -112.2 & -99.2 & -30.2 & 1 \\ 110.3 & -108.4 & -103.1 & -31.4 & 1 \\ 221 & -217.5 & -111.5 & -34.0 & 1 \\ 126.5 & -123.3 & -111.8 & -34.1 & 1 \\ 127 & -125.7 & -113.7 & -34.7 & 1 \\ 203.5 & -203.6 & -130.1 & -39.7 & 1 \\ 133.5 & -142.1 & -131.6 & -40.1 & 1 \\ 142.2 & -148.2 & -146 & -44.5 & 1 \\ 189 & -184.2 & -165.2 & -50.4 & 1 \\ 246 & -243.1 & -182.1 & -55.5 & 1 \\ 225.3 & -201.3 & -186 & -56.7 & 1 \\ 241.5 & -216.5 & -205 & -62.5 & 1 \\ 246.5 & -220.5 & -208 & -63.4 & 1 \\ & & & & \\ 52.9 & -18.9 & -2.5 & -0.8 & 1 \\ 48.7 & -17.7 & -5 & -1.5 & 1 \\ 48.3 & -12.3 & -0.5 & -0.2 & 1 \\ 44 & -11 & -1.5 & -0.5 & 1 \\ 34 & -5 & -2 & -0.6 & 1 \\ 87 & -67 & -67 & -20.4 & 1 \\ 97 & -74 & -72 & -21.9 & 1 \\ 92 & -69 & -66 & -20.1 & 1 \\ & & & & \end{array}$

$\begin{array}{rrrrrr}\text { Tt } & 58 & 17.7 & 0 & 13 & 46 \\ \text { Tt } & 57 & 17.4 & 0 & 7 & 33 \\ \text { Tt } & 68.5 & 20.9 & 0 & 10 & 41 \\ \text { Tt } & 79 & 24.1 & 0 & 7 & 34 \\ \text { Tt } & 80.5 & 24.5 & 0 & 4 & 46 \\ \text { Tt } & 87 & 26.5 & 0 & 8 & 39 \\ \text { Tt } & 89 & 27.1 & 0 & 4 & 49 \\ \text { Tt } & 90 & 27.4 & 0 & 8 & 48 \\ \text { Tt } & 98.5 & 30.0 & 0 & 5 & 48 \\ \text { Tt } & 108 & 32.9 & 0 & 6 & 112 \\ \text { Tt } & 119 & 36.3 & 0 & 6 & 115 \\ \text { Tt } & 117 & 35.7 & 0 & 6 & 84 \\ \text { Tt } & 109 & 33.2 & 0 & 12 & 69 \\ \text { Tt } & 119 & 36.3 & 0 & 11 & 68 \\ \text { Tt } & 127 & 38.7 & 0 & 5 & 66 \\ \text { Tt } & 130 & 39.6 & 0 & 15 & 63 \\ \text { Tt } & 128 & 39.0 & 0 & 8 & 67 \\ \text { Tt } & 130 & 39.6 & 0 & 6 & 59 \\ \text { Tt } & 120 & 36.6 & 0 & 4 & 66 \\ \text { Tt } & 128 & 39.0 & 0 & 4 & 60 \\ \text { Tt } & 105 & 32.0 & 0 & & \\ \text { Tt } & 115 & 35.1 & 0 & 5 & 81 \\ \text { Tt } & 115 & 35.1 & 0 & 10 & 94 \\ \text { Tt } & 115 & 35.1 & 0 & 5 & 87 \\ \text { Tt } & 130 & 39.6 & 0 & 5 & 106 \\ \text { Tt } & 123 & 37.5 & 0 & 10 & 91 \\ \text { Tt } & 140 & 42.7 & 0 & 10 & 79 \\ \text { Tt } & 170 & 51.8 & 0 & 3 & 81 \\ \text { Tt } & 185 & 56.4 & 0 & 5 & 97 \\ \text { Tt } & 210 & 64.0 & 0 & 1 & 82 \\ \text { SRM } & 230 & 70.1 & 0 & 2 & 85 \\ \text { SRM } & 234 & 71.3 & 0 & 2 & 111 \\ & & & & & \\ \text { Grvl } & 36.5 & 11.1 & 0 & 4 & 27 \\ \text { S\&G } & 36 & 11.0 & 0 & 4 & 23 \\ \text { Grvl } & 36.5 & 11.1 & 0 & 5 & 33 \\ \text { Grvl } & 34.5 & 10.5 & 0 & 3 & 23 \\ \text { Grvl } & 31 & 9.4 & 0 & 2 & 18 \\ & & & & & \\ \text { Grvl } & 87 & 26.5 & 0 & & \\ \text { Grvl } & 95 & 29.0 & 0 & & \\ \text { Grvl } & 89 & 27.1 & 0 & & \\ & & & & & \end{array}$


Elev Ft Depth Ft Base Ft Contactft ContactM Code Lithol Feet Meters Code Min Max

PDX

AIR FORCE

PDX

Terminal 11

Fremont

Bridge

Marine Dr

RR Bridge

$N$ Marine Dr

Highway Bridge

Vancouver

Shipyards

1966

1963

$\begin{array}{rrrr}544 & 520551 & 5052503 & 19 \\ 545 & 520997 & 5052334 & 14 \\ 546 & 519945 & 5052777 & 12 \\ & & & \\ 547 & 530600 & 5047448 & 8.82 \\ 548 & 530644 & 5047448 & 8.82 \\ 549 & 530687 & 5047450 & 8.82 \\ & & & \\ 550 & 523163 & 5043659 & 27.6 \\ 551 & \mathbf{5 2 3 1 8 7} & 5043703 & 27.4 \\ 552 & 523178 & 5043683 & 27.2 \\ 553 & 523186 & 5043644 & 28.1 \\ 554 & 523203 & 5043681 & 26.1 \\ & & & \\ 555 & 525024 & 5042790 & 32.6 \\ 556 & 525047 & 5042770 & 32.4 \\ 557 & 525000 & 5042716 & 14.7 \\ 558 & 524964 & 5042715 & 8.4 \\ 559 & 524979 & 5042695 & 8.6 \\ 560 & 524705 & 5042414 & 24.2 \\ 561 & 524730 & 5042392 & 31.6 \\ & & & \\ 562 & 523189 & 5050908 & 29.42 \\ 563 & 523231 & 5050930 & 28.72 \\ & & & \\ 564 & 521969 & 5051372 & 33.17 \\ 565 & 522064 & 5051363 & 28.62 \\ 566 & 522161 & 5051381 & 32.18 \\ 567 & 522277 & 5051390 & 25.87 \\ & & & \\ 568 & 528586 & 5051163 & 29 \\ 569 & 528615 & 5051050 & 27.5 \\ 570 & 528586 & 5050888 & 27 \\ 571 & 525264 & 5052026 & 33 \\ 572 & 525270 & 5051994 & 30 \\ 573 & 525284 & 5051958 & 29.5 \\ 574 & 525237 & 5051978 & 31 \\ 575 & 525301 & 5052005 & 29.5 \\ 576 & 525085 & 5052033 & 32 \\ 577 & 525136 & 5052071 & 32 \\ 578 & 525135 & 5052035 & 27.4 \\ 579 & 525098 & 5052067 & 27.4\end{array}$

$\begin{array}{rrrrr}101 & -82 & -80 & -24.4 & 1 \\ 93 & -79 & -76 & -23.2 & 1 \\ 84 & -72 & -70 & -21.3 & 1 \\ & & & & \\ 40 & -31.18 & 0 & 0.0 & 0 \\ 80 & -71.18 & 0 & 0.0 & 0 \\ 40 & -31.18 & 0 & 0.0 & 0 \\ 81.5 & -53.9 & 0 & 0.0 & 0 \\ 18 & 9.4 & 0 & 0.0 & 0 \\ 28.5 & -1.3 & 0 & 0.0 & 0 \\ 26.5 & 1.6 & 0 & 0.0 & 0 \\ 83.5 & -57.4 & 0 & 0.0 & 0 \\ & & & & \\ 91 & -58.4 & -3.4 & -1.0 & 1 \\ 91 & -58.6 & -3 & -0.9 & 1 \\ 122 & -107.3 & -8 & -2.4 & 1 \\ 66 & -57.6 & -7 & -2.1 & 1 \\ 66 & -57.4 & -28 & -8.5 & 1 \\ 150 & -125.8 & -87 & -26.5 & 1 \\ 173 & -141.4 & -90 & -27.4 & 1 \\ & & & & \\ 127.5 & -98.08 & -87.6 & -26.7 & 1 \\ 132.2 & -103.48 & -93.3 & -28.4 & 1 \\ 100.8 & -67.63 & -66.3 & -20.2 & 1 \\ 111.5 & -82.88 & -71.38 & -21.8 & 1 \\ 119 & -86.82 & -74.52 & -22.7 & 1 \\ 113.3 & -87.43 & -82.63 & -25.2 & 1 \\ 23.5 & 5.5 & 6.5 & 2.0 & 1 \\ 24 & 3.5 & 10 & 3.0 & 1 \\ 44 & -17 & 24.5 & 7.5 & 1 \\ 35 & -2 & 3 & 0.9 & 1 \\ 37 & -7 & -5 & -1.5 & 1 \\ 43 & -13.5 & -10 & -3.0 & 1 \\ 42 & -11 & -9 & -2.7 & 1 \\ 30 & -0.5 & 1.5 & 0.5 & 1 \\ 45 & -13 & -6 & -1.8 & 1 \\ 33 & -1 & 5 & 1.5 & 1 \\ 42 & -14.6 & -11.6 & -3.5 & 1 \\ 34.5 & -7.1 & 0.4 & 0.1 & 1 \\ & & & & \end{array}$

$\begin{array}{llll}\text { Grvl } & 99 & 30.2 & 0 \\ \text { Grvl } & 90 & 27.4 & 0 \\ \text { Grvl } & 82 & 25.0 & 0 \\ & & & \\ & 40 & 12.2 & 0 \\ & 80 & 24.4 & 0 \\ & 40 & 12.2 & 0\end{array}$

$\begin{array}{lllll}81.5 & 24.8 & 0 & 3 & 35\end{array}$

$\begin{array}{lll}18 & 5.5 & 0\end{array}$

$28.5 \quad 8.7 \quad 0$

$\begin{array}{rrrrr}26.5 & 8.1 & 0 & 5 & 28\end{array}$

Grvl $36 \quad 11.0$

$\begin{array}{lrrr}\text { Grvl } & 35.4 & 10.8 & 0 \\ \text { Grvl } & 22.7 & 6.9 & 0\end{array}$

$\begin{array}{llll}\text { Grvl } & 15.4 & 4.7\end{array}$

Grvl $36.6 \quad 11.2$

Grvl $111.2 \quad 33.9$

Grvl 121.6 37.1

$\begin{array}{llllll}\text { Grvl } & 117 & 35.7 & 0 & 3 & 54 \\ \text { Grvl } & 122 & 37.2 & 0 & 2 & 59\end{array}$

$\begin{array}{lrrrrr}\text { Grvl } & 99.5 & 30.3 & 1 & 3 & 40 \\ \text { Grvl } & 100 & 30.5 & 0 & 3 & 28\end{array}$

$\begin{array}{llllll}\text { Grvl } & 106.7 & 32.5 & 1 & 2 & 40\end{array}$

Grvi $108.5 \quad 33.1 \quad 1 \quad 2 \quad 47$

$\begin{array}{rrrr}\text { Grvl } & 22.5 & 6.9 & 0 \\ \text { Grvl } & 17.5 & 5.3 & 0 \\ \text { Grvl } & 2.5 & 0.8 & 0 \\ \text { G\&Cobls } & 30 & 9.1 & 0 \\ \text { Grvl } & 35 & 10.6 & 0 \\ \text { G\&Cobls } & 39.5 & 12.0 & 0 \\ \text { Grvl } & 40 & 12.2 & 0 \\ \text { Grvl } & 28 & 8.5 & 0 \\ \text { S\&G } & 38 & 11.6 & 0 \\ \text { S\&G } & 27 & 8.2 & 0 \\ \text { Grvl } & 39 & 11.9 & 0 \\ \text { G\&Cobls } & 27 & 8.2 & 0\end{array}$



Elev Ft Depth Ft Base Ft Contactft ContactM Code Lithol Feet Meters Code Min Max

\begin{tabular}{|c|c|c|c|c|c|c|c|c|c|c|c|c|c|c|c|}
\hline Water Wells & $\begin{array}{l}580 \\
581\end{array}$ & $\begin{array}{l}524904 \\
524881\end{array}$ & $\begin{array}{l}5052150 \\
5052158\end{array}$ & $\begin{array}{l}35 \\
27\end{array}$ & $\begin{array}{r}127.5 \\
184\end{array}$ & $\begin{array}{r}-92.5 \\
-157\end{array}$ & $\begin{array}{r}35 \\
2\end{array}$ & $\begin{array}{r}10.7 \\
0.6\end{array}$ & $\begin{array}{l}1 \\
1\end{array}$ & $\begin{array}{r}\text { Grvl } \\
\text { G\&Cobls }\end{array}$ & $\begin{array}{r}0 \\
102\end{array}$ & $\begin{array}{r}0.0 \\
31.1\end{array}$ & $\begin{array}{l}0 \\
0\end{array}$ & & \\
\hline BPA Hayden I & $\begin{array}{l}582 \\
583\end{array}$ & $\begin{array}{l}522103 \\
522113\end{array}$ & $\begin{array}{l}5053134 \\
5053107\end{array}$ & $\begin{array}{l}13 \\
13\end{array}$ & $\begin{array}{r}39 \\
38.5\end{array}$ & $\begin{array}{r}-26 \\
-25.5\end{array}$ & $\begin{array}{l}0 \\
0\end{array}$ & $\begin{array}{l}0.0 \\
0.0\end{array}$ & $\begin{array}{l}0 \\
0\end{array}$ & & $\begin{array}{r}39 \\
38.5\end{array}$ & $\begin{array}{l}11.9 \\
11.7\end{array}$ & $\begin{array}{l}0 \\
0\end{array}$ & $\begin{array}{l}7 \\
5\end{array}$ & $\begin{array}{l}15 \\
15\end{array}$ \\
\hline BPA Vancouver & $\begin{array}{l}584 \\
585\end{array}$ & $\begin{array}{l}522551 \\
522537\end{array}$ & $\begin{array}{l}5054018 \\
5054049\end{array}$ & $\begin{array}{l}20 \\
20\end{array}$ & $\begin{array}{l}42 \\
41\end{array}$ & $\begin{array}{l}-22 \\
-21\end{array}$ & $\begin{array}{l}0 \\
0\end{array}$ & $\begin{array}{l}0.0 \\
0.0\end{array}$ & $\begin{array}{l}0 \\
0\end{array}$ & & $\begin{array}{l}42 \\
41\end{array}$ & $\begin{array}{l}12.8 \\
12.5\end{array}$ & $\begin{array}{l}0 \\
0\end{array}$ & $\begin{array}{l}2 \\
1\end{array}$ & $\begin{array}{l}16 \\
20\end{array}$ \\
\hline $\begin{array}{l}\text { Vancouver } \\
\text { Waste Water } \\
\text { Plant }\end{array}$ & $\begin{array}{l}586 \\
587 \\
588 \\
589 \\
590 \\
591 \\
592 \\
593\end{array}$ & $\begin{array}{l}523647 \\
523615 \\
523564 \\
523485 \\
523441 \\
523453 \\
523513 \\
523551\end{array}$ & $\begin{array}{l}5054816 \\
5054667 \\
5054438 \\
5054451 \\
5054500 \\
5054658 \\
5054891 \\
5054799\end{array}$ & $\begin{array}{r}24.5 \\
22.5 \\
24 \\
22 \\
18 \\
23.5 \\
22 \\
21.5\end{array}$ & $\begin{array}{l}51.5 \\
26.5 \\
36.5 \\
26.5 \\
26.5 \\
31.5 \\
31.5 \\
26.5\end{array}$ & $\begin{array}{r}-27 \\
-4 \\
-12.5 \\
-4.5 \\
-8.5 \\
-8 \\
-9.5 \\
-5\end{array}$ & $\begin{array}{r}-19.5 \\
0 \\
0 \\
0 \\
0 \\
0 \\
0 \\
0\end{array}$ & $\begin{array}{r}-5.9 \\
0.0 \\
0.0 \\
0.0 \\
0.0 \\
0.0 \\
0.0 \\
0.0\end{array}$ & $\begin{array}{l}1 \\
0 \\
0 \\
0 \\
0 \\
0 \\
0 \\
0\end{array}$ & Grvl & $\begin{array}{r}44 \\
26.5 \\
36.5 \\
26.5 \\
26.5 \\
31.5 \\
31.5 \\
26.5\end{array}$ & $\begin{array}{r}13.4 \\
8.1 \\
11.1 \\
8.1 \\
8.1 \\
9.6 \\
9.6 \\
8.1\end{array}$ & $\begin{array}{l}0 \\
0 \\
0 \\
0 \\
0 \\
0 \\
0 \\
0\end{array}$ & $\begin{array}{l}5 \\
5 \\
5 \\
5 \\
8 \\
5 \\
3 \\
6\end{array}$ & $\begin{array}{l}39 \\
44 \\
38 \\
43 \\
27 \\
33 \\
39 \\
39\end{array}$ \\
\hline $\begin{array}{l}\text { City of } \\
\text { Vancouver } \\
\text { Waste } \\
\text { Lagoon }\end{array}$ & $\begin{array}{l}594 \\
595 \\
596 \\
597 \\
598 \\
599 \\
600\end{array}$ & $\begin{array}{l}523522 \\
523542 \\
523427 \\
523396 \\
523418 \\
523477 \\
523523\end{array}$ & $\begin{array}{l}5054122 \\
5054350 \\
5054183 \\
5054362 \\
5054281 \\
5054270 \\
5054227\end{array}$ & $\begin{array}{l}22.7 \\
26.9 \\
22.7 \\
21.7 \\
23.1 \\
22.8 \\
23.7\end{array}$ & $\begin{array}{r}39.5 \\
41 \\
40.5 \\
41.5 \\
40.3 \\
38.3 \\
38.5\end{array}$ & $\begin{array}{l}-16.8 \\
-14.1 \\
-17.8 \\
-19.8 \\
-17.2 \\
-15.5 \\
-14.8\end{array}$ & $\begin{array}{r}-3.3 \\
2.4 \\
-8.8 \\
-4.3 \\
-6.4 \\
-1.2 \\
0.2\end{array}$ & $\begin{array}{r}-1.0 \\
0.7 \\
-2.7 \\
-1.3 \\
-2.0 \\
-0.4 \\
0.1\end{array}$ & $\begin{array}{l}1 \\
1 \\
1 \\
1 \\
1 \\
1 \\
1\end{array}$ & $\begin{array}{l}\text { Grvl } \\
\text { Grvl } \\
\text { Grvl } \\
\text { Grvl } \\
\text { Grvl } \\
\text { Grvl } \\
\text { Grvl }\end{array}$ & $\begin{array}{r}26 \\
24.5 \\
31.5 \\
26 \\
29.5 \\
24 \\
23.5\end{array}$ & $\begin{array}{l}7.9 \\
7.5 \\
9.6 \\
7.9 \\
9.0 \\
7.3 \\
7.2\end{array}$ & $\begin{array}{l}0 \\
0 \\
0 \\
0 \\
0 \\
0 \\
0\end{array}$ & $\begin{array}{r}3 \\
7 \\
9 \\
13 \\
10 \\
8 \\
7\end{array}$ & $\begin{array}{l}16 \\
27 \\
24 \\
33 \\
26 \\
30 \\
45\end{array}$ \\
\hline Sewage $P$ lant & $\begin{array}{l}601 \\
602 \\
603 \\
604 \\
605\end{array}$ & $\begin{array}{l}524049 \\
524084 \\
524567 \\
524692 \\
525441\end{array}$ & $\begin{array}{l}5055911 \\
5053213 \\
5052626 \\
5052497 \\
5052317\end{array}$ & $\begin{array}{r}36 \\
30 \\
47.5 \\
42 \\
42\end{array}$ & $\begin{array}{r}56.5 \\
44 \\
31.5 \\
26.5 \\
26.5\end{array}$ & $\begin{array}{r}-20.5 \\
-14 \\
16 \\
15.5 \\
15.5\end{array}$ & $\begin{array}{r}-19 \\
0 \\
47.5 \\
42 \\
42\end{array}$ & $\begin{array}{r}-5.8 \\
0.0 \\
14.5 \\
12.8 \\
12.8\end{array}$ & $\begin{array}{l}1 \\
0 \\
1 \\
1 \\
1\end{array}$ & $\begin{array}{l}\text { Grvl } \\
\text { S\&G } \\
\text { S\&G } \\
\text { S\&G }\end{array}$ & $\begin{array}{r}55 \\
44 \\
0 \\
0 \\
0\end{array}$ & $\begin{array}{r}16.8 \\
13.4 \\
0.0 \\
0.0 \\
0.0\end{array}$ & $\begin{array}{l}0 \\
0 \\
0 \\
0 \\
0\end{array}$ & & \\
\hline $\begin{array}{c}\text { Vancouver } \\
\text { Lake }\end{array}$ & $\begin{array}{l}606 \\
607 \\
608 \\
609 \\
610 \\
611 \\
612\end{array}$ & $\begin{array}{l}523471 \\
522273 \\
520442 \\
520791 \\
521848 \\
522020 \\
522674\end{array}$ & $\begin{array}{l}5058204 \\
5056785 \\
5057371 \\
5058987 \\
5060117 \\
5058015 \\
5058975\end{array}$ & $\begin{array}{r}1.9 \\
2.1 \\
2.6 \\
1.9 \\
4.6 \\
1.9 \\
2\end{array}$ & $\begin{array}{r}7.5 \\
15.5 \\
15 \\
15 \\
14 \\
7.5 \\
7.5\end{array}$ & $\begin{array}{r}-5.6 \\
-13.4 \\
-12.4 \\
-13.1 \\
-9.4 \\
-5.6 \\
-5.5\end{array}$ & $\begin{array}{l}0 \\
0 \\
0 \\
0 \\
0 \\
0 \\
0\end{array}$ & $\begin{array}{l}0.0 \\
0.0 \\
0.0 \\
0.0 \\
0.0 \\
0.0 \\
0.0\end{array}$ & $\begin{array}{l}0 \\
0 \\
0 \\
0 \\
0 \\
0 \\
0\end{array}$ & . & $\begin{array}{r}7.5 \\
15.5 \\
15 \\
15 \\
14 \\
7.5 \\
7.5\end{array}$ & $\begin{array}{l}2.3 \\
4.7 \\
4.6 \\
4.6 \\
4.3 \\
2.3 \\
2.3\end{array}$ & $\begin{array}{l}0 \\
0 \\
0 \\
0 \\
0 \\
0 \\
0\end{array}$ & & \\
\hline Alcoa Vancouver & $\begin{array}{l}613 \\
614\end{array}$ & $\begin{array}{l}521017 \\
521115\end{array}$ & $\begin{array}{l}5054713 \\
5054855\end{array}$ & $\begin{array}{l}28.33 \\
28.84\end{array}$ & $\begin{array}{l}136 \\
111\end{array}$ & $\begin{array}{r}-107.67 \\
-82.16\end{array}$ & $\begin{array}{l}-81.7 \\
-62.2\end{array}$ & $\begin{array}{l}-24.9 \\
-19.0\end{array}$ & $\begin{array}{l}1 \\
1\end{array}$ & $\begin{array}{l}\text { S\&G } \\
\text { S\&G }\end{array}$ & $\begin{array}{r}110 \\
91\end{array}$ & $\begin{array}{l}33.5 \\
27.7\end{array}$ & $\begin{array}{l}0 \\
0\end{array}$ & & \\
\hline
\end{tabular}


Hole Hole QalBasal QalBasal GIS

Basal Isopach Isopach Asin SPT

Elev Ft Depth Ft Base Ft Contactft ContactM Code Lithol Feet Meters Code Min Max

\begin{tabular}{|c|c|c|c|c|c|c|c|c|c|c|c|c|c|c|c|}
\hline & $\begin{array}{l}615 \\
616 \\
617 \\
618 \\
619 \\
620 \\
621\end{array}$ & $\begin{array}{l}520986 \\
521132 \\
521094 \\
521058 \\
520790 \\
520855 \\
520931\end{array}$ & $\begin{array}{l}5054728 \\
5054717 \\
5054650 \\
5054702 \\
5055069 \\
5055106 \\
5055181\end{array}$ & $\begin{array}{r}27.7 \\
30.16 \\
28.44 \\
29.24 \\
26.14 \\
28.26 \\
28.71\end{array}$ & $\begin{array}{l}136 \\
119 \\
130 \\
146 \\
135 \\
133 \\
166\end{array}$ & $\begin{array}{r}-108.3 \\
-88.84 \\
-101.56 \\
-116.76 \\
-108.86 \\
-104.74 \\
-137.29\end{array}$ & $\begin{array}{l}-81.3 \\
-63.8 \\
-72.6 \\
-73.8 \\
-79.9 \\
-75.7 \\
-77.3\end{array}$ & $\begin{array}{l}-24.8 \\
-19.4 \\
-22.1 \\
-22.5 \\
-24.4 \\
-23.1 \\
-23.6\end{array}$ & $\begin{array}{l}1 \\
1 \\
1 \\
1 \\
1 \\
1 \\
1\end{array}$ & $\begin{array}{c}\text { S\&G } \\
\text { Grvl } \\
\text { Grvl } \\
\text { S\&G } \\
\text { Tt } \\
\text { Tt } \\
\text { Tt }\end{array}$ & $\begin{array}{r}109 \\
94 \\
101 \\
103 \\
106 \\
104 \\
106\end{array}$ & $\begin{array}{l}33.2 \\
28.7 \\
30.8 \\
31.4 \\
32.3 \\
31.7 \\
32.3\end{array}$ & $\begin{array}{l}0 \\
0 \\
0 \\
0 \\
0 \\
0 \\
0\end{array}$ & & \\
\hline Scappoose RR & $\begin{array}{l}622 \\
623 \\
624 \\
625 \\
626\end{array}$ & $\begin{array}{l}509943 \\
509967 \\
509934 \\
509956 \\
509929\end{array}$ & $\begin{array}{l}5058473 \\
5058580 \\
5058377 \\
5058531 \\
5058266\end{array}$ & $\begin{array}{r}15 \\
10 \\
14 \\
15 \\
19.5\end{array}$ & $\begin{array}{r}48 \\
49 \\
49 \\
58.2 \\
42\end{array}$ & $\begin{array}{r}-33 \\
-39 \\
-35 \\
-43.2 \\
-22.5\end{array}$ & $\begin{array}{l}-20 \\
-25 \\
-11 \\
-24 \\
-5.5\end{array}$ & $\begin{array}{l}-6.1 \\
-7.6 \\
-3.4 \\
-7.3 \\
-1.7\end{array}$ & $\begin{array}{l}1 \\
1 \\
1 \\
1 \\
1\end{array}$ & $\begin{array}{l}T t \\
T t \\
T t \\
T t \\
T t\end{array}$ & $\begin{array}{l}35 \\
35 \\
25 \\
39 \\
25\end{array}$ & $\begin{array}{r}10.7 \\
10.7 \\
7.6 \\
11.9 \\
7.6\end{array}$ & $\begin{array}{l}0 \\
0 \\
0 \\
0 \\
0\end{array}$ & $\begin{array}{l}3 \\
1 \\
2 \\
1\end{array}$ & $\begin{array}{r}23 \\
11 \\
7 \\
7\end{array}$ \\
\hline $\begin{array}{l}\text { ODOT } \\
\text { I-5 Bridge }\end{array}$ & $\begin{array}{l}627 \\
628 \\
629 \\
630 \\
631 \\
632 \\
633 \\
634 \\
635 \\
636\end{array}$ & $\begin{array}{l}525574 \\
525545 \\
525509 \\
525478 \\
525351 \\
525319 \\
525261 \\
525250 \\
525239 \\
525225\end{array}$ & $\begin{array}{l}5051853 \\
5051792 \\
5051702 \\
5051622 \\
5051324 \\
5051251 \\
5051101 \\
5051079 \\
5051051 \\
5051021\end{array}$ & $\begin{array}{r}22 \\
-22 \\
-34.5 \\
-29 \\
-19.5 \\
-21 \\
10 \\
21 \\
22 \\
23.5\end{array}$ & $\begin{array}{r}26 \\
34 \\
21.5 \\
79 \\
75.5 \\
103.5 \\
80 \\
93 \\
68 \\
93.5\end{array}$ & $\begin{array}{r}-4 \\
-56 \\
-56 \\
-108 \\
-95 \\
-124.5 \\
-70 \\
-72 \\
-46 \\
-70\end{array}$ & $\begin{array}{r}17.5 \\
-31 \\
-63.5 \\
-86.5 \\
0 \\
0 \\
0 \\
0 \\
0 \\
0\end{array}$ & $\begin{array}{r}5.3 \\
-9.4 \\
-19.4 \\
-26.4 \\
0.0 \\
0.0 \\
0.0 \\
0.0 \\
0.0 \\
0.0\end{array}$ & $\begin{array}{l}1 \\
1 \\
1 \\
1 \\
0 \\
0 \\
0 \\
0 \\
0 \\
0\end{array}$ & $\begin{array}{l}\text { Grvl } \\
\text { Grvl } \\
\text { Grvl } \\
\text { S\&G }\end{array}$ & $\begin{array}{r}4.5 \\
9 \\
29 \\
57.5 \\
75.5 \\
103.5 \\
80 \\
93 \\
68 \\
93.5\end{array}$ & $\begin{array}{r}1.4 \\
2.7 \\
8.8 \\
17.5 \\
23.0 \\
31.5 \\
24.4 \\
28.3 \\
20.7 \\
28.5\end{array}$ & $\begin{array}{l}0 \\
0 \\
0 \\
0 \\
0 \\
0 \\
0 \\
0 \\
0 \\
0\end{array}$ & & \\
\hline $\begin{array}{l}\text { ODOT } \\
\text { Oregon slough } \\
\text { Bridge }\end{array}$ & $\begin{array}{l}637 \\
638 \\
639 \\
640 \\
641 \\
642 \\
643\end{array}$ & $\begin{array}{l}525001 \\
524956 \\
524930 \\
524900 \\
524855 \\
524851 \\
524843\end{array}$ & $\begin{array}{l}5050464 \\
5050345 \\
5050289 \\
5050205 \\
5050154 \\
5050131 \\
5050111\end{array}$ & $\begin{array}{r}48 \\
-12.5 \\
-18.6 \\
-11.5 \\
28.4 \\
32 \\
32.5\end{array}$ & $\begin{array}{r}186 \\
104.75 \\
100 \\
97 \\
61.6 \\
96.5 \\
98\end{array}$ & $\begin{array}{r}-138 \\
-117.25 \\
-118.6 \\
-108.5 \\
-33.2 \\
-64.5 \\
-65.5\end{array}$ & $\begin{array}{r}-127 \\
-117 \\
-118.6 \\
-108.5 \\
0 \\
0 \\
0\end{array}$ & $\begin{array}{r}-38.7 \\
-35.7 \\
-36.1 \\
-33.1 \\
0.0 \\
0.0 \\
0.0\end{array}$ & $\begin{array}{l}1 \\
1 \\
1 \\
1 \\
0 \\
0 \\
0\end{array}$ & $\begin{array}{l}\text { S\&G } \\
\text { Qfc } \\
\text { Qfc } \\
\text { Qfc }\end{array}$ & $\begin{array}{r}175 \\
104.5 \\
100 \\
97 \\
61.6 \\
96.5 \\
98\end{array}$ & $\begin{array}{l}53.3 \\
31.9 \\
30.5 \\
29.6 \\
18.8 \\
29.4 \\
29.9\end{array}$ & $\begin{array}{l}0 \\
0 \\
0 \\
0 \\
0 \\
0 \\
0\end{array}$ & & \\
\hline $\begin{array}{l}\text { ODOT } \\
\text { I } 205 \\
\text { Airport } \\
\text { Interchange }\end{array}$ & $\begin{array}{l}644 \\
645 \\
646 \\
647 \\
648 \\
649\end{array}$ & $\begin{array}{l}535190 \\
535338 \\
535262 \\
535229 \\
535254 \\
535300\end{array}$ & $\begin{array}{l}5046301 \\
5046248 \\
5046190 \\
5046332 \\
5046304 \\
5046317\end{array}$ & $\begin{array}{r}18.1 \\
41.2 \\
16 \\
19.6 \\
16.6 \\
18.6\end{array}$ & $\begin{array}{r}127.5 \\
139 \\
199.5 \\
241 \\
205 \\
253.5\end{array}$ & $\begin{array}{r}-109.4 \\
-97.8 \\
-183.5 \\
-221.4 \\
-188.4 \\
-234.9\end{array}$ & $\begin{array}{r}0 \\
0 \\
0 \\
-212.4 \\
0 \\
-214.9\end{array}$ & $\begin{array}{r}0.0 \\
0.0 \\
0.0 \\
-64.7 \\
0.0 \\
-65.5\end{array}$ & $\begin{array}{l}0 \\
0 \\
0 \\
1 \\
0 \\
1\end{array}$ & $\begin{array}{l}\text { SRM } \\
\text { SRM }\end{array}$ & $\begin{array}{r}127.5 \\
139 \\
199.5 \\
232 \\
205 \\
233.5\end{array}$ & $\begin{array}{l}38.9 \\
42.4 \\
60.8 \\
70.7 \\
62.5 \\
71.2\end{array}$ & $\begin{array}{l}0 \\
1 \\
1 \\
0 \\
1 \\
1\end{array}$ & & \\
\hline $\begin{array}{l}\text { POP } \\
\text { Govt. IsI }\end{array}$ & $\begin{array}{l}650 \\
651\end{array}$ & $\begin{array}{l}537315 \\
536636\end{array}$ & $\begin{array}{l}5046551 \\
5047101\end{array}$ & $\begin{array}{l}23 \\
26\end{array}$ & $\begin{array}{r}55 \\
53.5\end{array}$ & $\begin{array}{r}-32 \\
-27.5\end{array}$ & $\begin{array}{l}0 \\
0\end{array}$ & $\begin{array}{l}0.0 \\
0.0\end{array}$ & $\begin{array}{l}0 \\
0\end{array}$ & & $\begin{array}{r}55 \\
53.5\end{array}$ & $\begin{array}{l}16.8 \\
16.3\end{array}$ & $\begin{array}{l}0 \\
0\end{array}$ & & \\
\hline
\end{tabular}




$\begin{array}{lrrrrrlll}652 & 536367 & 5047397 & 17 & 55 & -38 & 0 & 0.0 & 0 \\ 653 & 536028 & 5047698 & 17 & 55 & -38 & 0 & 0.0 & 0 \\ 654 & 535760 & 5048138 & 6 & 55 & -49 & 0 & 0.0 & 0 \\ 655 & 536132 & 5047530 & 16 & 50.5 & -34.5 & 0 & 0.0 & 0 \\ 656 & 537117 & 5047329 & 23 & 50.5 & -27.5 & 0 & 0.0 & 0 \\ 657 & 535396 & 5048581 & -2.5 & 28.5 & -31 & 0 & 0.0 & 0 \\ 658 & 534659 & 5048957 & -5 & 26.5 & -31.5 & 0 & 0.0 & 0 \\ 659 & 534156 & 5048883 & 3 & 32.5 & -29.5 & 0 & 0.0 & 0 \\ 660 & 533620 & 5049043 & -6 & 26 & -32 & 0 & 0.0 & 0 \\ 661 & 533205 & 5049238 & -18 & 16 & -34 & 0 & 0.0 & 0 \\ 662 & 535928 & 5046503 & -8.5 & 23 & -31.5 & 0 & 0.0 & 0 \\ 663 & 536450 & 5046228 & -8.5 & 23 & -31.5 & 0 & 0.0 & 0 \\ 664 & 537022 & 5045984 & -3.5 & 27 & -30.5 & 0 & 0.0 & 0 \\ 665 & 532457 & 5049389 & -27.5 & 19 & -46.5 & 0 & 0.0 & 0 \\ 666 & 532019 & 5049461 & -16 & 26 & -42 & 0 & 0.0 & 0 \\ 667 & 531850 & 5049602 & -25 & 17.5 & -42.5 & 0 & 0.0 & 0 \\ 668 & 532040 & 5049829 & -19.5 & 21.5 & -41 & 0 & 0.0 & 0 \\ 669 & 532188 & 5050070 & -11 & 15.5 & -26.5 & 0 & 0.0 & 0 \\ 670 & 531920 & 5050155 & -10 & 21 & -31 & 0 & 0.0 & 0 \\ 671 & 531525 & 5049391 & -20 & 32 & -52 & 0 & 0.0 & 0 \\ 672 & 532219 & 5049328 & -3 & 31 & -34 & 0 & 0.0 & 0 \\ 673 & 532891 & 5049027 & -5 & 35 & -40 & 0 & 0.0 & 0 \\ 674 & 533396 & 5048645 & -5 & 30 & -35 & 0 & 0.0 & 0 \\ 675 & 533885 & 5048322 & -13 & 30 & -43 & 0 & 0.0 & 0 \\ 676 & 534188 & 5048002 & -3 & 38 & -41 & 0 & 0.0 & 0 \\ 677 & 534737 & 5047583 & -13.5 & 30.5 & -44 & 0 & 0.0 & 0 \\ 678 & 535140 & 5047282 & -13.5 & 45 & -58.5 & 0 & 0.0 & 0 \\ 679 & 535501 & 5046815 & -17 & 29 & -46 & 0 & 0.0 & 0 \\ 680 & 533867 & 5048011 & -11 & 47.5 & -58.5 & 0 & 0.0 & 0 \\ 681 & 532834 & 5048648 & -5 & 57 & -62 & 0 & 0.0 & 0 \\ 682 & 534469 & 5047556 & -14 & 37 & -51 & 0 & 0.0 & 0 \\ 683 & 532147 & 5049096 & -18 & 44 & -62 & 0 & 0.0 & 0 \\ 684 & 535162 & 5046931 & -7 & 53 & -60 & 0 & 0.0 & 0 \\ 685 & 531025 & 5049492 & -8 & 51.5 & -59.5 & 0 & 0.0 & 0 \\ 686 & 531177 & 5049564 & -13 & 51.5 & -64.5 & 0 & 0.0 & 0 \\ 687 & 531202 & 5049427 & -4.5 & 51.5 & -56 & 0 & 0.0 & 0 \\ 688 & 531338 & 5049470 & -13.5 & 43 & -56.5 & 0 & 0.0 & 0 \\ 689 & 531674 & 5049336 & -18 & 16.5 & -34.5 & 0 & 0.0 & 0 \\ 690 & 531676 & 5049244 & -15.5 & 37.5 & -53 & 0 & 0.0 & 0 \\ 691 & 531965 & 5049271 & -14 & 41.5 & -55.5 & 0 & 0.0 & 0 \\ 692 & 531962 & 5049134 & -15.5 & 39.5 & -55 & 0 & 0.0 & 0 \\ 693 & 532265 & 5049144 & -7 & 46 & -53 & 0 & 0.0 & 0\end{array}$

Elev Ft Depth Ft Base Ft ContactFt ContactM Code Lithol Feet Meters Code Min Max

$\begin{array}{rrr}55 & 16.8 & 0 \\ 55 & 16.8 & 0 \\ 55 & 16.8 & 0 \\ 50.5 & 15.4 & 0 \\ 50.5 & 15.4 & 0 \\ 28.5 & 8.7 & 0 \\ 26.5 & 8.1 & 0 \\ 32.5 & 9.9 & 0 \\ 26 & 7.9 & 0 \\ 16 & 4.9 & 0 \\ 23 & 7.0 & 0 \\ 23 & 7.0 & 0 \\ 27 & 8.2 & 0 \\ 19 & 5.8 & 0 \\ 26 & 7.9 & 0 \\ 17.5 & 5.3 & 0 \\ 21.5 & 6.6 & 0 \\ 15.5 & 4.7 & 0 \\ 21 & 6.4 & 0 \\ 32 & 9.8 & 0 \\ 31 & 9.4 & 0 \\ 35 & 10.7 & 0 \\ 30 & 9.1 & 0 \\ 30 & 9.1 & 0 \\ 38 & 11.6 & 0 \\ 30.5 & 9.3 & 0 \\ 45 & 13.7 & 0 \\ 29 & 8.8 & 0 \\ 47.5 & 14.5 & 0 \\ 57 & 17.4 & 0 \\ 37 & 11.3 & 0 \\ 44 & 13.4 & 0 \\ 53 & 16.2 & 0 \\ 51.5 & 15.7 & 0 \\ 51.5 & 15.7 & 0 \\ 51.5 & 15.7 & 0 \\ 43 & 13.1 & 0 \\ 16.5 & 5.0 & 0 \\ 37.5 & 11.4 & 0 \\ 41.5 & 12.6 & 0 \\ 39.5 & 12.0 & 0 \\ 46 & 14.0 & 0 \\ & & \end{array}$



Elev Ft Depth Ft Base Ft Contactft ContactM Code Lithol Feet Meters Code Min Max

POP

Airport

Reynolds

Troutdale

$\begin{array}{rrrrrrrr}532542 & 5049030 & -5 & 59 & -64 & 0 & 0.0 & 0 \\ 532478 & 5048931 & -5 & 50 & -55 & 0 & 0.0 & 0 \\ 532870 & 5048850 & -4 & 49.5 & -53.5 & 0 & 0.0 & 0 \\ 532861 & 5048769 & -5 & 33 & -38 & 0 & 0.0 & 0 \\ 532834 & 5048749 & -5 & 33 & -38 & 0 & 0.0 & 0 \\ 532861 & 5048722 & -4.5 & 36.5 & -41 & 0 & 0.0 & 0 \\ 532892 & 5048750 & -4.5 & 24 & -28.5 & 0 & 0.0 & 0 \\ 533190 & 5048671 & -5.5 & 53.5 & -59 & 0 & 0.0 & 0 \\ 533610 & 5048562 & -13 & 37.5 & -50.5 & 0 & 0.0 & 0 \\ 533540 & 5048400 & -11 & 46.5 & -57.5 & 0 & 0.0 & 0 \\ 533489 & 5048280 & -9 & 33 & -42 & 0 & 0.0 & 0 \\ 534290 & 5048525 & 0 & 54 & -54 & 0 & 0.0 & 0 \\ 534119 & 5048180 & -11 & 42 & -53 & 0 & 0.0 & 0 \\ 534340 & 5047777 & -14 & 26 & -40 & 0 & 0.0 & 0 \\ 534545 & 5047837 & -2 & 55 & -57 & 0 & 0.0 & 0 \\ 534679 & 5048401 & 1 & 49.5 & -48.5 & 0 & 0.0 & 0 \\ 534476 & 5048389 & -7 & 47 & -54 & 0 & 0.0 & 0 \\ 535529 & 5046691 & -12 & 40.5 & -52.5 & 0 & 0.0 & 0 \\ 535898 & 5046673 & -1 & 47.5 & -48.5 & 0 & 0.0 & 0 \\ 535890 & 5046826 & -3 & 47 & -50 & 0 & 0.0 & 0 \\ 535973 & 5046356 & -6 & 47 & -53 & 0 & 0.0 & 0 \\ 537073 & 5045781 & -5 & 59 & -64 & 0 & 0.0 & 0 \\ 538304 & 5046163 & -2 & 57 & -59 & 0 & 0.0 & 0 \\ 538305 & 5045621 & 0 & 59.5 & -59.5 & 0 & 0.0 & 0 \\ 538292 & 5045721 & -2 & 27 & -29 & 0 & 0.0 & 0 \\ 536698 & 5046032 & -3 & 20.5 & -23.5 & 0 & 0.0 & 0 \\ 532436 & 5049125 & -7.5 & 42.5 & -50 & 0 & 0.0 & 0 \\ 532756 & 5048884 & -7.5 & 42.5 & -50 & 0 & 0.0 & 0 \\ 530158 & 5048621 & 7.2 & 52.5 & -45.3 & 0 & 0.0 & 0 \\ 529593 & 5048937 & 9.1 & 59.5 & -50.4 & 0 & 0.0 & 0 \\ 529969 & 5048722 & 7.2 & 60 & -52.8 & 0 & 0.0 & 0 \\ 529803 & 5048811 & 10.7 & 63 & -52.3 & 0 & 0.0 & 0 \\ 530317 & 5047849 & 15 & 60 & -45 & 0 & 0.0 & 0 \\ 530104 & 5047630 & 13 & 59 & -46 & 0 & 0.0 & 0 \\ 530375 & 5047664 & 12.3 & 61.1 & -48.8 & 0 & 0.0 & 0 \\ 530141 & 5047476 & 15 & 52 & -37 & 0 & 0.0 & 0 \\ & & & & & & \\ 546585 & 5044708 & 28.6 & 71.6 & -43 & 0 & 0.0 & 0 \\ 546469 & 5044895 & 23.2 & 51.9 & -28.7 & 0 & 0.0 & 0 \\ 546531 & 5044856 & 24.3 & 66.6 & -42.3 & 0 & 0.0 & 0 \\ 546471 & 5044810 & 22.7 & 56.4 & -33.7 & 0 & 0.0 & 0\end{array}$

$\begin{array}{rrr}59 & 18.0 & 0 \\ 50 & 15.2 & 0 \\ 49.5 & 15.1 & 0 \\ 33 & 10.1 & 0 \\ 33 & 10.1 & 0 \\ 36.5 & 11.1 & 0 \\ 24 & 7.3 & 0 \\ 53.5 & 16.3 & 0 \\ 37.5 & 11.4 & 0 \\ 46.5 & 14.2 & 0 \\ 33 & 10.1 & 0 \\ 54 & 16.5 & 0 \\ 42 & 12.8 & 0 \\ 26 & 7.9 & 0 \\ 55 & 16.8 & 0 \\ 49.5 & 15.1 & 0 \\ 47 & 14.3 & 0 \\ 40.5 & 12.3 & 0 \\ 47.5 & 14.5 & 0 \\ 47 & 14.3 & 0 \\ 47 & 14.3 & 0 \\ 59 & 18.0 & 0 \\ 57 & 17.4 & 0 \\ 59.5 & 18.1 & 0 \\ 27 & 8.2 & 0 \\ 20.5 & 6.2 & 0 \\ 42.5 & 13.0 & 0 \\ 42.5 & 13.0 & 0\end{array}$

$52.5 \quad 16.0 \quad 0$

$59.5 \quad 18.1$

6018.3

$\begin{array}{ll}63 & 19.2\end{array}$

$60 \quad 18.3$

$59 \quad 18.0$

$61.1 \quad 18.6$

19.6

$\begin{array}{lll}71.6 & 21.8 & 0\end{array}$

$\begin{array}{lll}51.9 & 15.8 & 0\end{array}$

$\begin{array}{lll}66.6 & 20.3 & 0 \\ 56.4 & 17.2 & 0\end{array}$ 
PGE Towers

sundial Rd

PP\&L Camas

Crossing

Delta Park

Sand Explor.

$\begin{array}{lll}734 & 546533 & 5044781 \\ 735 & 546478 & 5044727 \\ 736 & 546539 & 5044665 \\ 737 & 546484 & 5044597 \\ 738 & 546540 & 5044544 \\ 739 & 546475 & 5044504 \\ 740 & 546539 & 5044428 \\ 741 & 546752 & 5044566 \\ 742 & 546784 & 5044536 \\ 743 & 546807 & 5044572 \\ 744 & 546680 & 5044525\end{array}$

$\begin{array}{rrrlll}23.7 & 53.5 & -29.8 & 0 & 0.0 & 0 \\ 20 & 56 & -36 & 0 & 0.0 & 0 \\ 21.8 & 54.8 & -33 & 0 & 0.0 & 0 \\ 20.5 & 67 & -46.5 & 0 & 0.0 & 0 \\ 19.4 & 76.8 & -57.4 & 0 & 0.0 & 0 \\ 18.5 & 75 & -56.5 & 0 & 0.0 & 0 \\ 17.7 & 68.7 & -51 & 0 & 0.0 & 0 \\ 24 & 60.5 & -36.5 & 0 & 0.0 & 0 \\ 22 & 75.5 & -53.5 & 0 & 0.0 & 0 \\ 24.5 & 74.5 & -50 & 0 & 0.0 & 0 \\ 22 & 57.5 & -35.5 & 0 & 0.0 & 0\end{array}$

$\begin{array}{lll}745 & 546492 & 5045151 \\ 746 & 546048 & 5045189 \\ 747 & 545488 & 5044935 \\ 748 & 544677 & 5044930\end{array}$

$748 \quad 544677 \quad 5044930$

$\begin{array}{lll}749 & 543973 \quad 5044926\end{array}$

$\begin{array}{lll}750 & 545812 & 5046410 \\ 751 & 545828 & 5045552\end{array}$

$\begin{array}{lll}752 & 524742 & 5050388\end{array}$

$\begin{array}{lll}753 & 524388 & 5050496\end{array}$

$\begin{array}{lll}754 & 524272 & \mathbf{5 0 5 0 6 1 3}\end{array}$

$\begin{array}{lll}755 & 524064 & 5050612\end{array}$

$\begin{array}{lll}756 & 524002 \quad 5050752\end{array}$

$757 \quad 523801 \quad 5050735$

$\begin{array}{lll}758 & 523843 & 5050957\end{array}$

$\begin{array}{lll}759 & 523717 & 5050907\end{array}$

$761 \quad 523566 \quad 505086$

$767.523646-5051094$

$\begin{array}{lll}762 & 523001 & \mathbf{5 0 5 1 3 2 1} \\ \mathbf{7 6 3} & \mathbf{5 2 5 1 8 3} & \mathbf{5 0 5 0 1 1 7}\end{array}$

$\begin{array}{lll}764 & 525481 & 5050170\end{array}$

$765 \quad 525630 \quad 5049933$

$\begin{array}{lll}766 & 525902 \quad 5049904\end{array}$

$\begin{array}{lll}767 & 526219 & 5049792\end{array}$

$\begin{array}{lll}768 & 523976 & 5050082\end{array}$

Vanport

site

\section{$\begin{array}{lll}20 & 33.5 & -33.5\end{array}$}

$22 \quad 51.5 \quad-29.5$

$20 \quad 75.5 \quad-55.5$

$\begin{array}{ll}89.5 & -68.5 \\ 55.5 & -38.5\end{array}$

0
0
0
-67
-33

$\begin{array}{ll}0.0 & 0 \\ 0.0 & 0 \\ 0.0 & 0\end{array}$

0.00

$\begin{array}{lll}-20.4 & 1\end{array}$

$-10.1$

$\begin{array}{rr}-14.9 & 1 \\ 0.0 & 0\end{array}$

$\begin{array}{rr}65 & -52 \\ 58.5 & -43.5\end{array}$

-49
0

$23.5 \quad-46.5$

-23
-25

-25
-19
-16

-19
-16
-15

$-15$

$-14$

-16
-10.5

-10.5
-16
-9

-9
-13.5

-13.5
-15

$-16.5$

$-22$

$-18$

-20
7.5

7.5
11

6.7

5
14.2 $\begin{array}{ll}15 & -40 \\ 31 & -50\end{array}$

$18.5-34.5$

$30 \quad-45$

$27.5 \quad-41.5$

$\begin{array}{rr}28 & -44 \\ 35.5 & -46\end{array}$

$36.5-45.5$

$30.5 \quad-45.5$

$27.5 \quad-44$

$-44$

$-43$

$\begin{array}{rr}25 & -43 \\ 24 & -44 \\ 91.5 & -84\end{array}$

$91-80$

$83.7 \quad-77$

$\begin{array}{rr}83.7 & -77 \\ 75 & -70\end{array}$

$91.2 \quad-77$
0.00

$\begin{array}{ll}0.0 & 0 \\ 0.0 & 0\end{array}$

0.00

0.00

0.00

0.00

$0.0 \quad 0$

0.00

$\begin{array}{ll}0.0 & 0 \\ 0.0 & 0 \\ 0.0 & 0\end{array}$

0.00

0.00

$0.0 \quad 0$

0.00

0.00

$-25.3$

$-24.11$

$-23.21$

$\begin{array}{ll}-21.0 & 1\end{array}$
$21 \quad 89.5 \quad-68.5$

$27 \quad-43$

$33.5 \quad-47$
$523447 \quad 5050282$

5230615050416

$522898 \quad 5050031$

$\begin{array}{ll}522799 & 5049647\end{array}$ $\begin{array}{lll}53.5 & 16.3 \quad 0\end{array}$

$\begin{array}{rr}56 & 17.1 \\ 54.8 & 16.7\end{array}$

$67 \quad 20.4$

$76.8 \quad 23.4$

$75 \quad 22.9$

$68.7 \quad 20.9$

$60.5 \quad 18.4$

$75.5 \quad 23.0$

$74.5 \quad 22.7$

$\begin{array}{lll}57.5 & 17.5 & 0\end{array}$

$\begin{array}{lll}53.5 & 16.3 & 0\end{array}$

$\begin{array}{lll}51.5 & 15.7 & 0\end{array}$

Grvl $\quad 88 \quad 26.8 \quad 1$

Grvl

$50 \quad 15.2$

Bslt

$\begin{array}{rrr}62 & 18.9 & 0 \\ 58.5 & 17.8 & 0\end{array}$ 
N Marine Dr Crown Z.

POP

Delta Park West

Delta Park East

Rivergate

Crown 2. Front Ave

$\begin{array}{rrrrrr}8.8 & 93.8 & -85 & 0 & 0.0 & 0 \\ 11.6 & 102.6 & -91 & -89 & -27.1 & 1 \\ 15.8 & 97.3 & -81.5 & -80.5 & -24.5 & 1 \\ 14.3 & 121.3 & -107 & -106 & -32.3 & 1 \\ & & & & & \\ 28 & 113 & -85 & -84 & -25.6 & 1 \\ 26 & 117 & -91 & -90 & -27.4 & 1 \\ 11 & 97 & -86 & -84 & -25.6 & 1 \\ 10 & 93 & -83 & -83 & -25.3 & 1 \\ 8 & 91 & -83 & -82 & -25.0 & 1 \\ 12.5 & 46.5 & -34 & 0 & 0.0 & 0 \\ 7.5 & 39.5 & -32 & 0 & 0.0 & 0 \\ 8 & 45 & -37 & 0 & 0.0 & 0 \\ 26.5 & 27.5 & -1 & 0 & 0.0 & 0\end{array}$

$18.7 \quad 120.2-101.5$

18.7

120.2

117.9

115.3

116.2
101.5

-101.5
-95

-103
-100

-8
-84
-84
-85

$-25.0$ $-25.6$ $-25.6$ $-28.2$ 5050107

\section{$10.5 \quad 35.5$}

10.5

35.

5048745

5048698

5048642

5048678

9.5
8.5

78
35.5
36.5

-25
-27.5

35.5
36.5

$-70$

$795 \quad 526465$

5051947

5051358

5052131

5051168

5051487

5050255

5045533

5045533
5045397

5045209

5045527

5045577

5045604

5045380

5045445
$10 \quad 71 \quad-6$

$\begin{array}{lll}13 & 83 & -70\end{array}$

$150-125$

-125
-100

$-68$

$20 \quad 122$

30.5

$-5.5$

$-7.7$

-7.7
-16.7

2.5

-105
-68.5 $\begin{array}{lll}-102 & -95 & -29.0\end{array}$

$\begin{array}{lll}-101.5 & -30.9 & 1\end{array}$

0.00

$\begin{array}{ll}-29.3 & 1 \\ -32.8 & 1\end{array}$

0.00

$\begin{array}{lrrrrr} & 93.8 & 28.6 & 0 & & \\ \text { Grvl } & 100.6 & 30.7 & 1 & & \\ \text { Grvt } & 96.3 & 29.4 & 1 & & \\ \text { Grvl } & 120.3 & 36.7 & 1 & & \\ & & & & & \\ \text { Grvl } & 112 & 34.1 & 0 & 2 & 14 \text { * } \\ \text { Grvl } & 116 & 35.4 & 1 & 0 & 10 * \\ \text { Grvl } & 95 & 29.0 & 1 & 0 & 14 * \\ \text { Grvl } & 93 & 28.3 & 1 & 1 & 12 \text { * } \\ \text { Grvl } & 90 & 27.4 & 1 & 0 & 15 * \\ & 46.5 & 14.2 & 0 & 2 & 12 * \\ & 39.5 & 12.0 & 0 & 1 & 10 * \\ & 45 & 13.7 & 0 & 0 & 6 * \\ & 27.5 & 8.4 & 0 & 6 & 7 *\end{array}$

$\begin{array}{lll}\text { Grvl } & 100.7 & 30.7\end{array}$

Grvl $107 \quad 32.6$ 1 320 *

Grvl $96.3 \quad 29.4 \quad 0 \quad 2$ 15*

Grvl $101.7 \quad 31.0 \quad 1 \quad 4 \quad 12$ *

Grvl $\quad 100 \quad 30.5$

$\begin{array}{ll}35.5 & 10.8\end{array}$

$\begin{array}{ll}38 & 11.6 \\ 78 & 23.8\end{array}$

35.510 .8

36.511 .1

Grvl $\quad 64 \quad 19.5 \quad 0$

$\begin{array}{llll}\text { Grvl } & 77 & 23.5 & 0\end{array}$

Grvl $138 \quad 42.1 \quad 0$

Grvl $40 \quad 12.2 \quad 0$

$\begin{array}{lrrr}\text { Grvl } & 104 & 31.7 & 1 \\ \text { Grvl } & 70 & 21.3 & 1\end{array}$

Grvl $\quad 115 \quad 35.1 \quad 0$ 
Elev Ft Depth Ft Base Ft Contactft ContactM Code Lithol Feet Meters Code Min Max

\begin{tabular}{|c|c|c|c|c|c|c|c|c|c|c|c|c|}
\hline & $\begin{array}{l}810 \\
811 \\
812 \\
813 \\
814 \\
815 \\
816 \\
817 \\
818 \\
819\end{array}$ & $\begin{array}{l}520717 \\
520767 \\
520567 \\
520647 \\
520707 \\
520792 \\
520729 \\
520803 \\
520890 \\
520951\end{array}$ & $\begin{array}{l}5045518 \\
5045427 \\
5045522 \\
5045469 \\
5045382 \\
5045299 \\
5045683 \\
5045618 \\
5045552 \\
5045439\end{array}$ & $\begin{array}{l}35.9 \\
35.4 \\
27.6 \\
35.7 \\
35.8 \\
33.4 \\
-4.8 \\
-8.3 \\
-8.3 \\
2.2\end{array}$ & $\begin{array}{r}91.5 \\
93 \\
80 \\
80.5 \\
77.5 \\
78.5 \\
77.2 \\
94.7 \\
94.7 \\
92.2\end{array}$ & $\begin{array}{r}-55.6 \\
-57.6 \\
-52.4 \\
-44.8 \\
-41.7 \\
-45.1 \\
-82 \\
-103 \\
-103 \\
-90\end{array}$ & $\begin{array}{r}-54.35 \\
-55.1 \\
-46.9 \\
-43.3 \\
-41.2 \\
-44.6 \\
-78.5 \\
-91.5 \\
-82 \\
-68\end{array}$ & $\begin{array}{l}-16.6 \\
-16.8 \\
-14.3 \\
-13.2 \\
-12.6 \\
-13.6 \\
-23.9 \\
-27.9 \\
-25.0 \\
-20.7\end{array}$ & $\begin{array}{l}1 \\
1 \\
1 \\
1 \\
1 \\
1 \\
1 \\
1 \\
1 \\
1\end{array}$ & $\begin{array}{l}\text { Bslt } \\
\text { Grvl } \\
\text { Bslt } \\
\text { Bslt } \\
\text { Bslt } \\
\text { Bslt } \\
\text { Bslt } \\
\text { Grvl } \\
\text { G\&Cobls } \\
\text { G\&Cobls }\end{array}$ & $\begin{array}{r}90.25 \\
90.5 \\
74.5 \\
79 \\
77 \\
78 \\
73.7 \\
83.2 \\
73.7 \\
70.2\end{array}$ & $\begin{array}{l}27.5 \\
27.6 \\
22.7 \\
24.1 \\
23.5 \\
23.8 \\
22.5 \\
25.4 \\
22.5 \\
21.4\end{array}$ \\
\hline East Swan Isl & $\begin{array}{l}820 \\
821 \\
822 \\
823 \\
824 \\
825 \\
826 \\
827 \\
828 \\
829 \\
830 \\
831 \\
832 \\
833 \\
834 \\
835 \\
836 \\
837 \\
838 \\
839 \\
840 \\
841\end{array}$ & $\begin{array}{l}521912 \\
521929 \\
522089 \\
522091 \\
522244 \\
522243 \\
522479 \\
522509 \\
522722 \\
522865 \\
521736 \\
521641 \\
522652 \\
522338 \\
522213 \\
522751 \\
522578 \\
522437 \\
522202 \\
522131 \\
521955 \\
521780\end{array}$ & $\begin{array}{l}5045874 \\
5045903 \\
5045744 \\
5045772 \\
5045632 \\
5045663 \\
5045445 \\
5045462 \\
5045290 \\
5045172 \\
5045705 \\
5045741 \\
5044809 \\
5045047 \\
5045144 \\
5044611 \\
5044689 \\
5044836 \\
5045011 \\
5045057 \\
5045202 \\
5045330\end{array}$ & $\begin{array}{r}31.5 \\
31.5 \\
31.5 \\
31.5 \\
30.6 \\
31.6 \\
30.6 \\
31.5 \\
31.7 \\
31.5 \\
31.4 \\
31.6 \\
31.8 \\
30.8 \\
30.9 \\
-35 \\
-34.2 \\
-22.5 \\
-27.4 \\
-28.1 \\
-30.2 \\
-32\end{array}$ & $\begin{array}{r}80 \\
184.5 \\
80.5 \\
173.5 \\
80.6 \\
167.6 \\
80.6 \\
170.5 \\
151.7 \\
136 \\
80.4 \\
184.6 \\
130.8 \\
164.8 \\
160.9 \\
38 \\
103.8 \\
49.5 \\
121.6 \\
53.4 \\
123.3 \\
49\end{array}$ & $\begin{array}{r}-48.5 \\
-153 \\
-49 \\
-142 \\
-50 \\
-136 \\
-50 \\
-139 \\
-120 \\
-104.5 \\
-49 \\
-153 \\
-99 \\
-134 \\
-130 \\
-73 \\
-138 \\
-72 \\
-149 \\
-81.5 \\
-153.5 \\
-81\end{array}$ & $\begin{array}{r}0 \\
-143 \\
0 \\
-131 \\
0 \\
-124 \\
0 \\
-124 \\
-118 \\
-90 \\
0 \\
-142.5 \\
0 \\
-121 \\
-127 \\
0 \\
-118 \\
0 \\
-135.5 \\
0 \\
-140 \\
0\end{array}$ & $\begin{array}{r}0.0 \\
-43.6 \\
0.0 \\
-39.9 \\
0.0 \\
-37.8 \\
0.0 \\
-37.8 \\
-36.0 \\
-27.4 \\
0.0 \\
-43.4 \\
0.0 \\
-36.9 \\
-38.7 \\
0.0 \\
-36.0 \\
0.0 \\
-41.3 \\
0.0 \\
-42.7 \\
0.0\end{array}$ & $\begin{array}{l}0 \\
1 \\
0 \\
1 \\
0 \\
1 \\
0 \\
1 \\
1 \\
1 \\
0 \\
1 \\
0 \\
1 \\
1 \\
0 \\
1 \\
0 \\
1 \\
0 \\
1 \\
0\end{array}$ & $\begin{array}{l}\text { Grvl } \\
\text { Grvl } \\
\text { Grvl } \\
\text { Grvl } \\
\text { Grvl } \\
\text { Grvl } \\
\text { Grvl } \\
\text { Grvl } \\
\text { Grvl } \\
\text { s\&G } \\
\text { Grvl } \\
\text { Grvl }\end{array}$ & $\begin{array}{r}80 \\
174.5 \\
80.5 \\
162.5 \\
80.6 \\
155.6 \\
80.6 \\
155.5 \\
149.7 \\
121.5 \\
80.4 \\
174.1 \\
130.8 \\
151.8 \\
157.9 \\
38 \\
83.8 \\
49.5 \\
108.1 \\
53.4 \\
109.8 \\
49\end{array}$ & $\begin{array}{l}24.4 \\
53.2 \\
24.5 \\
49.5 \\
24.6 \\
47.4 \\
24.6 \\
47.4 \\
45.6 \\
37.0 \\
24.5 \\
53.1 \\
39.9 \\
46.3 \\
48.1 \\
11.6 \\
25.5 \\
15.1 \\
32.9 \\
16.3 \\
33.5 \\
14.9\end{array}$ \\
\hline $\begin{array}{l}\text { Swan Isl } \\
\text { Ory Dock }\end{array}$ & $\begin{array}{l}842 \\
843 \\
844 \\
845 \\
846 \\
847 \\
848 \\
849\end{array}$ & $\begin{array}{l}521951 \\
522021 \\
522280 \\
522501 \\
522110 \\
521319 \\
521476 \\
521719\end{array}$ & $\begin{array}{l}5046365 \\
5046413 \\
5046521 \\
5046448 \\
5046425 \\
5045698 \\
5045565 \\
5045402\end{array}$ & $\begin{array}{r}34 \\
34 \\
28 \\
26 \\
35 \\
-45.6 \\
-31.5 \\
-14.2\end{array}$ & $\begin{array}{r}126 \\
101.5 \\
111 \\
95 \\
112 \\
88.9 \\
102.5 \\
126.3\end{array}$ & $\begin{array}{r}-92 \\
-67.5 \\
-83 \\
-69 \\
-77 \\
-134.5 \\
-134 \\
-140.5\end{array}$ & $\begin{array}{r}0 \\
0 \\
0 \\
0 \\
0 \\
-126 \\
-129 \\
-131\end{array}$ & $\begin{array}{r}0.0 \\
0.0 \\
0.0 \\
0.0 \\
0.0 \\
-38.4 \\
-39.3 \\
-39.9\end{array}$ & $\begin{array}{l}0 \\
0 \\
0 \\
0 \\
0 \\
1 \\
1 \\
1\end{array}$ & $\begin{array}{l}\text { Grvl } \\
\text { Grvl } \\
\text { Grvl }\end{array}$ & $\begin{array}{r}126 \\
101.5 \\
111 \\
95 \\
112 \\
80.4 \\
97.5 \\
116.8\end{array}$ & $\begin{array}{l}38.4 \\
30.9 \\
33.8 \\
29.0 \\
34.1 \\
24.5 \\
29.7 \\
35.6\end{array}$ \\
\hline
\end{tabular}




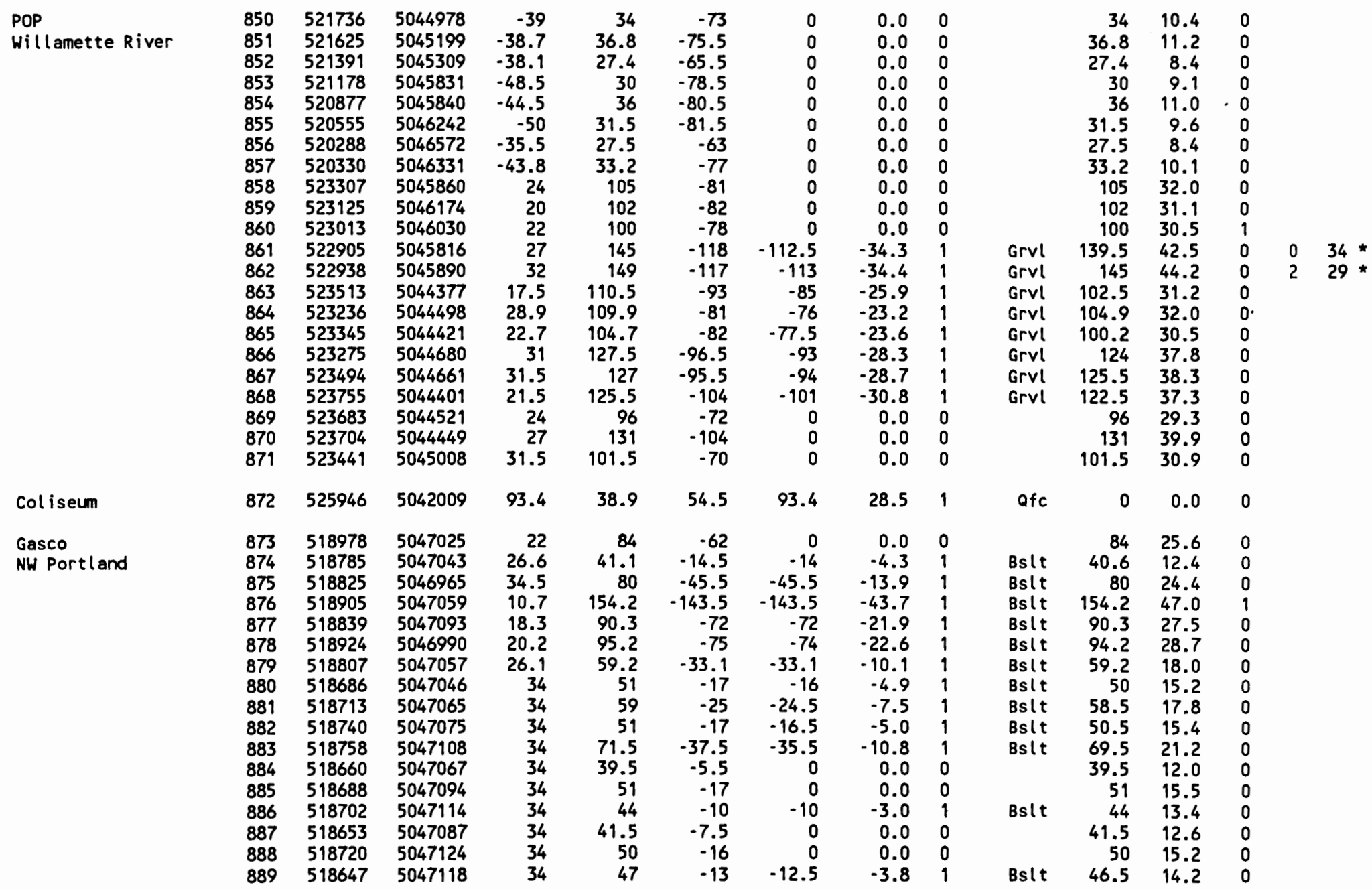


Basal I sopach Isopach Ash SPT Elev Ft Depth Ft Base Ft Contactft ContactM Code Lithol Feet Meters Code Min Max

\begin{tabular}{|c|c|c|c|c|c|c|c|c|c|c|c|c|c|c|c|}
\hline & $\begin{array}{l}890 \\
891 \\
892 \\
893 \\
894 \\
895 \\
896 \\
897 \\
898 \\
899 \\
900 \\
901 \\
902\end{array}$ & $\begin{array}{l}518682 \\
518681 \\
518797 \\
518748 \\
518771 \\
518731 \\
518662 \\
518729 \\
518704 \\
519005 \\
518941 \\
518724 \\
518707\end{array}$ & $\begin{array}{l}5047135 \\
5047164 \\
5047145 \\
5047150 \\
5047205 \\
5047197 \\
5047232 \\
5047272 \\
5047232 \\
5047072 \\
5047047 \\
5047219 \\
5047203\end{array}$ & $\begin{array}{l}34 \\
34 \\
34 \\
34 \\
34 \\
34 \\
36 \\
34 \\
34 \\
25 \\
26 \\
19 \\
35\end{array}$ & $\begin{array}{r}42.5 \\
47.5 \\
92 \\
84 \\
102 \\
89.5 \\
60 \\
106.5 \\
91.5 \\
201.5 \\
105 \\
75 \\
84\end{array}$ & $\begin{array}{r}-8.5 \\
-13.5 \\
-58 \\
-50 \\
-68 \\
-55.5 \\
-24 \\
-72.5 \\
-57.5 \\
-176.5 \\
-79 \\
-56 \\
-49\end{array}$ & $\begin{array}{r}0 \\
-13.5 \\
-58 \\
-50 \\
-67 \\
-55.5 \\
0 \\
0 \\
-57 \\
-176 \\
0 \\
-56 \\
-49\end{array}$ & $\begin{array}{r}0.0 \\
-4.1 \\
-17.7 \\
-15.2 \\
-20.4 \\
-16.9 \\
0.0 \\
0.0 \\
-17.4 \\
-53.6 \\
0.0 \\
-17.1 \\
-14.9\end{array}$ & $\begin{array}{l}0 \\
1 \\
1 \\
1 \\
1 \\
1 \\
0 \\
0 \\
1 \\
1 \\
0 \\
1 \\
1\end{array}$ & $\begin{array}{l}\text { Bslt } \\
\text { Bslt } \\
\text { Bslt } \\
\text { Bslt } \\
\text { Bslt } \\
\text { Bslt } \\
\text { Bslt } \\
\text { Bslt } \\
\text { Bslt }\end{array}$ & $\begin{array}{r}42.5 \\
47.5 \\
92 \\
84 \\
101 \\
89.5 \\
60 \\
106.5 \\
91 \\
201 \\
105 \\
75 \\
84\end{array}$ & $\begin{array}{l}13.0 \\
14.5 \\
28.0 \\
25.6 \\
30.8 \\
27.3 \\
18.3 \\
32.5 \\
27.7 \\
61.3 \\
32.0 \\
22.9 \\
25.6\end{array}$ & $\begin{array}{l}0 \\
0 \\
0 \\
0 \\
0 \\
0 \\
0 \\
0 \\
0 \\
0 \\
0 \\
0 \\
0\end{array}$ & $\begin{array}{l}4 \\
1\end{array}$ & $\begin{array}{l}27 \text { * } \\
20 \text { * } \\
22 \text { * } \\
29 *\end{array}$ \\
\hline $\begin{array}{l}\text { PGE } \\
\text { Will amette } \\
\text { Linnton } \\
\text { Harborton }\end{array}$ & $\begin{array}{l}903 \\
904 \\
905 \\
906 \\
907 \\
908 \\
909 \\
910 \\
911 \\
912 \\
913 \\
914 \\
915 \\
916 \\
917 \\
918\end{array}$ & $\begin{array}{l}516747 \\
516176 \\
515968 \\
516145 \\
516170 \\
515919 \\
515942 \\
515951 \\
515978 \\
516077 \\
516054 \\
516025 \\
516078 \\
516023 \\
516054 \\
516056\end{array}$ & $\begin{array}{l}5051327 \\
5050968 \\
5050849 \\
5051053 \\
5051019 \\
5050910 \\
5050887 \\
5050936 \\
5050907 \\
5051063 \\
5051038 \\
5051010 \\
5051001 \\
5050979 \\
5050989 \\
5050961\end{array}$ & $\begin{array}{r}21.94 \\
18.97 \\
17 \\
25.5 \\
29 \\
-3 \\
-2.5 \\
0 \\
1 \\
22.5 \\
22.6 \\
22.7 \\
23.7 \\
23.6 \\
23.9 \\
23.7\end{array}$ & $\begin{array}{r}99 \\
98 \\
44 \\
135 \\
134 \\
43.5 \\
31.5 \\
35.5 \\
70 \\
52 \\
71 \\
91.5 \\
65.5 \\
56 \\
57.5 \\
58.5\end{array}$ & $\begin{array}{r}-77.06 \\
-79.03 \\
-27 \\
-109.5 \\
-105 \\
-46.5 \\
-34 \\
-35.5 \\
-69 \\
-29.5 \\
-48.4 \\
-68.8 \\
-41.8 \\
-32.4 \\
-33.6 \\
-34.8\end{array}$ & $\begin{array}{r}0 \\
0 \\
-23 \\
-108.5 \\
-103.5 \\
-46.5 \\
0 \\
0 \\
-68 \\
-29 \\
-47.9 \\
-68.3 \\
-41.3 \\
-32.4 \\
-33.6 \\
-34.8\end{array}$ & $\begin{array}{r}0.0 \\
0.0 \\
-7.0 \\
-33.1 \\
-31.5 \\
-14.2 \\
0.0 \\
0.0 \\
-20.7 \\
-8.8 \\
-14.6 \\
-20.8 \\
-12.6 \\
-9.9 \\
-10.2 \\
-10.6\end{array}$ & $\begin{array}{l}0 \\
0 \\
1 \\
1 \\
1 \\
1 \\
0 \\
0 \\
1 \\
1 \\
1 \\
1 \\
1 \\
1 \\
1 \\
1\end{array}$ & $\begin{array}{l}\text { Bslt } \\
\text { Bslt } \\
\text { Bslt } \\
\text { Grvl } \\
\text { Grvl } \\
\text { Bslt } \\
\text { Bslt } \\
\text { Bslt } \\
\text { Bslt } \\
\text { Bslt } \\
\text { Bslt } \\
\text { Bslt }\end{array}$ & $\begin{array}{r}99 \\
98 \\
40 \\
134 \\
132.5 \\
43.5 \\
31.5 \\
35.5 \\
69 \\
51.5 \\
70.5 \\
91 \\
65 \\
56 \\
57.5 \\
58.5\end{array}$ & $\begin{array}{r}30.2 \\
29.9 \\
12.2 \\
40.8 \\
40.4 \\
13.3 \\
9.6 \\
10.8 \\
21.0 \\
15.7 \\
21.5 \\
27.7 \\
19.8 \\
17.1 \\
17.5 \\
17.8\end{array}$ & $\begin{array}{l}0 \\
1 \\
0 \\
0 \\
1 \\
0 \\
0 \\
0 \\
0 \\
0 \\
0 \\
0 \\
0 \\
0 \\
0 \\
0\end{array}$ & $\begin{array}{l}1 \\
0 \\
2 \\
3 \\
4 \\
4 \\
5\end{array}$ & $\begin{array}{r}32 \\
17 \\
5 \\
46 \\
24 \\
60 \\
58\end{array}$ \\
\hline $\begin{array}{l}\text { Union Pacific RR } \\
\text { St. Johns } \\
\text { Ramsay\&Lombard }\end{array}$ & $\begin{array}{l}919 \\
920 \\
921 \\
922 \\
923 \\
924\end{array}$ & $\begin{array}{l}517423 \\
517449 \\
517766 \\
518372 \\
518071 \\
517637\end{array}$ & $\begin{array}{l}5051954 \\
5051468 \\
5051394 \\
5051267 \\
5051335 \\
5052094\end{array}$ & $\begin{array}{l}16 \\
15 \\
13 \\
23 \\
13 \\
37\end{array}$ & $\begin{array}{r}31 \\
80 \\
56 \\
61 \\
65 \\
126.5\end{array}$ & $\begin{array}{r}-15 \\
-65 \\
-43 \\
-38 \\
-52 \\
-89.5\end{array}$ & $\begin{array}{l}0 \\
0 \\
0 \\
0 \\
0 \\
0\end{array}$ & $\begin{array}{l}0.0 \\
0.0 \\
0.0 \\
0.0 \\
0.0 \\
0.0\end{array}$ & $\begin{array}{l}0 \\
0 \\
0 \\
0 \\
0 \\
0\end{array}$ & & $\begin{array}{r}31 \\
80 \\
56 \\
61 \\
65 \\
126.5\end{array}$ & $\begin{array}{l}9.4 \\
24.4 \\
17.1 \\
18.6 \\
19.8 \\
38.6\end{array}$ & $\begin{array}{l}0 \\
1 \\
0 \\
0 \\
1 \\
0\end{array}$ & 5 & $31 *$ \\
\hline Morr\&knudsen & $\begin{array}{l}925 \\
926 \\
927\end{array}$ & $\begin{array}{l}517923 \\
517269 \\
516999\end{array}$ & $\begin{array}{l}5051050 \\
5050977 \\
5050962\end{array}$ & $\begin{array}{r}21 \\
27.5 \\
27\end{array}$ & $\begin{array}{r}130 \\
167.5 \\
101\end{array}$ & $\begin{array}{r}-109 \\
-140 \\
-74\end{array}$ & $\begin{array}{l}0 \\
0 \\
0\end{array}$ & $\begin{array}{l}0.0 \\
0.0 \\
0.0\end{array}$ & $\begin{array}{l}0 \\
0 \\
0\end{array}$ & & $\begin{array}{r}130 \\
167.5 \\
101\end{array}$ & $\begin{array}{l}39.6 \\
51.1 \\
30.8\end{array}$ & $\begin{array}{l}1 \\
1 \\
1\end{array}$ & 3 & $\begin{array}{l}12 \text { * } \\
42 \text { * }\end{array}$ \\
\hline
\end{tabular}


Map ID\# UTM EAST UTM NORTH Surface Hole Hole BalBasal QalBasal GIS Basal isopach isopach Ash SPT

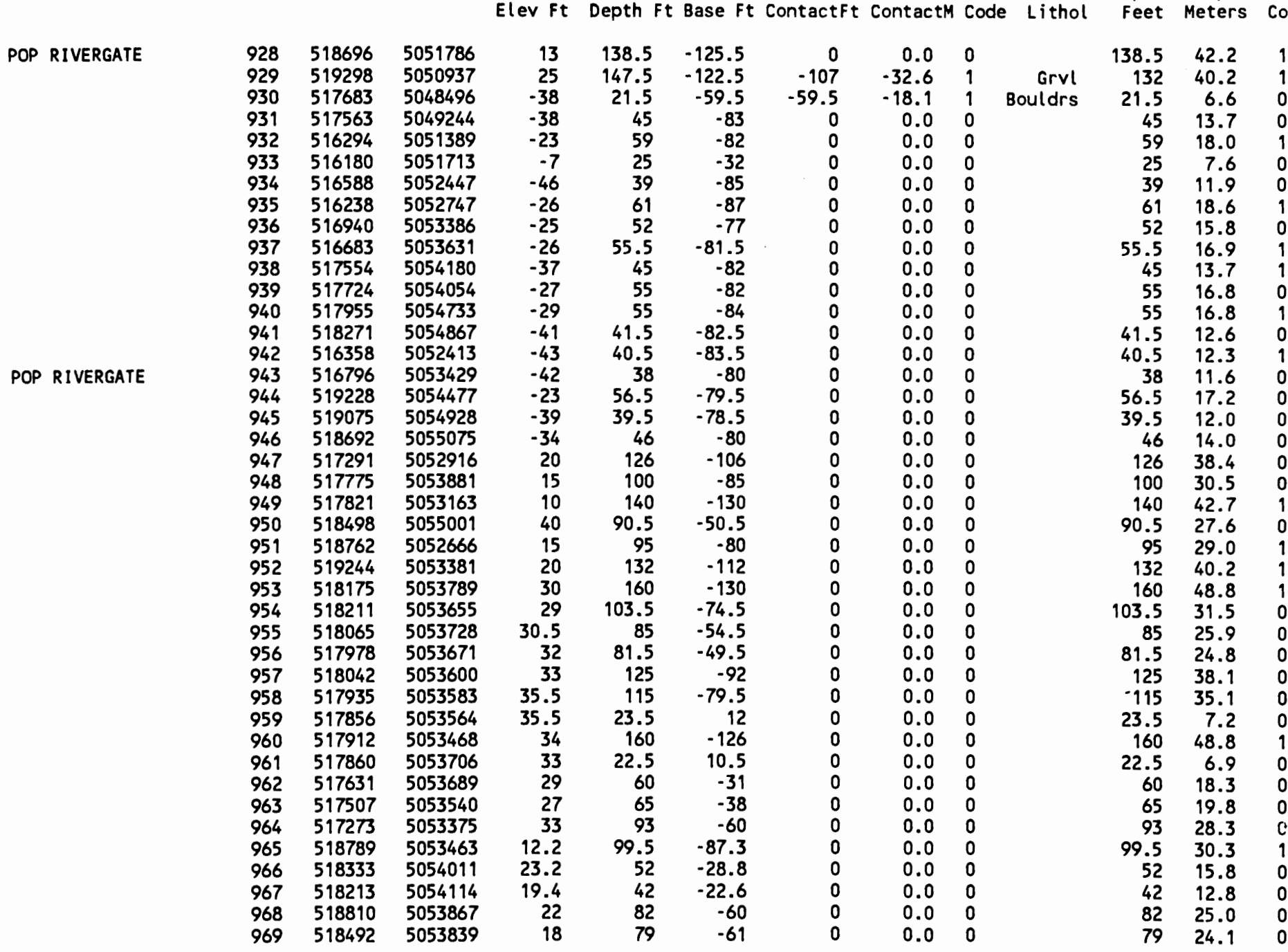



lev Ft Depth Ft Base Ft ContactFt ContactM Code Lithol Feet Meters Code Min Max

\begin{tabular}{|c|c|c|c|c|c|c|c|c|c|c|c|c|c|c|c|}
\hline & $\begin{array}{l}970 \\
971 \\
972 \\
973\end{array}$ & $\begin{array}{l}517509 \\
517523 \\
517584 \\
517612\end{array}$ & $\begin{array}{l}5052632 \\
5052572 \\
5052629 \\
5052567\end{array}$ & $\begin{array}{l}35 \\
35 \\
33 \\
33\end{array}$ & $\begin{array}{l}173 \\
128 \\
130 \\
130\end{array}$ & $\begin{array}{r}-138 \\
-93 \\
-97 \\
-97\end{array}$ & $\begin{array}{r}-135.5 \\
0 \\
0 \\
0\end{array}$ & $\begin{array}{r}-41.3 \\
0.0 \\
0.0 \\
0.0\end{array}$ & $\begin{array}{l}1 \\
0 \\
0 \\
0\end{array}$ & Grvl & $\begin{array}{r}170.5 \\
128 \\
130 \\
130\end{array}$ & $\begin{array}{l}52.0 \\
39.0 \\
39.6 \\
39.6\end{array}$ & $\begin{array}{l}0 \\
0 \\
0 \\
0\end{array}$ & 0 & 56 * \\
\hline Grain Terminal & $\begin{array}{l}974 \\
975 \\
976 \\
977 \\
978 \\
979 \\
980 \\
981\end{array}$ & $\begin{array}{l}518046 \\
518076 \\
518114 \\
517910 \\
517957 \\
517129 \\
517207 \\
517281\end{array}$ & $\begin{array}{l}5054123 \\
5054074 \\
5054034 \\
5054139 \\
5054187 \\
5053285 \\
5053250 \\
5053217\end{array}$ & $\begin{array}{r}30 \\
30 \\
31 \\
-28.5 \\
-28 \\
35.5 \\
35.5 \\
35.5\end{array}$ & $\begin{array}{r}120 \\
156 \\
124 \\
144.5 \\
131 \\
162 \\
157.5 \\
161\end{array}$ & $\begin{array}{r}-90 \\
-126 \\
-93 \\
-173 \\
-159 \\
-126.5 \\
-122 \\
-125.5\end{array}$ & $\begin{array}{r}0 \\
0 \\
0 \\
0 \\
0 \\
-124.5 \\
-121.5 \\
0\end{array}$ & $\begin{array}{r}0.0 \\
0.0 \\
0.0 \\
0.0 \\
0.0 \\
-37.9 \\
-37.0 \\
0.0\end{array}$ & $\begin{array}{l}0 \\
0 \\
0 \\
0 \\
0 \\
1 \\
1 \\
0\end{array}$ & $\begin{array}{l}\text { Grvl } \\
\text { Grvl }\end{array}$ & $\begin{array}{r}120 \\
156 \\
124 \\
144.5 \\
131 \\
160 \\
157 \\
161\end{array}$ & $\begin{array}{l}36.6 \\
47.5 \\
37.8 \\
44.0 \\
39.9 \\
48.8 \\
47.9 \\
49.1\end{array}$ & $\begin{array}{l}1 \\
0 \\
0 \\
0 \\
0 \\
0 \\
0 \\
0\end{array}$ & $\begin{array}{l}2 \\
3 \\
0 \\
0 \\
0 \\
2 \\
1 \\
2\end{array}$ & $\begin{array}{l}30 \text { * } \\
44 \text { * } \\
36 \\
100 \text { * } \\
70 \text { * } \\
50 \\
34 \text { * } \\
40 \text { * }\end{array}$ \\
\hline $\begin{array}{l}\text { Oregon } \\
\text { steel Mills }\end{array}$ & $\begin{array}{l}982 \\
983 \\
984 \\
985\end{array}$ & $\begin{array}{l}516759 \\
517097 \\
516737 \\
517059\end{array}$ & $\begin{array}{l}5052567 \\
5052434 \\
5052435 \\
5052350\end{array}$ & $\begin{array}{r}32.1 \\
32 \\
30 \\
30\end{array}$ & $\begin{array}{r}101.1 \\
113 \\
82 \\
106\end{array}$ & $\begin{array}{l}-69 \\
-81 \\
-52 \\
-76\end{array}$ & $\begin{array}{l}0 \\
0 \\
0 \\
0\end{array}$ & $\begin{array}{l}0.0 \\
0.0 \\
0.0 \\
0.0\end{array}$ & $\begin{array}{l}0 \\
0 \\
0 \\
0\end{array}$ & & $\begin{array}{r}101.1 \\
113 \\
82 \\
106\end{array}$ & $\begin{array}{l}30.8 \\
34.4 \\
25.0 \\
32.3\end{array}$ & $\begin{array}{l}1 \\
1 \\
0 \\
0\end{array}$ & & \\
\hline PP\&L Suavies Isl & 986 & 515479 & 5052733 & 10 & 40 & -30 & 0 & 0.0 & 0 & & 40 & 12.2 & $0^{\circ}$ & & \\
\hline P. of Portland & $\begin{array}{l}987 \\
988 \\
989 \\
990\end{array}$ & $\begin{array}{l}520324 \\
520400 \\
519606 \\
519758\end{array}$ & $\begin{array}{l}5052268 \\
5053055 \\
5053008 \\
5053630\end{array}$ & $\begin{array}{l}22 \\
24 \\
14 \\
20\end{array}$ & $\begin{array}{r}58 \\
82 \\
101 \\
75.5\end{array}$ & $\begin{array}{r}-36 \\
-58 \\
-87 \\
-55.5\end{array}$ & $\begin{array}{l}0 \\
0 \\
0 \\
0\end{array}$ & $\begin{array}{l}0.0 \\
0.0 \\
0.0 \\
0.0\end{array}$ & $\begin{array}{l}0 \\
0 \\
0 \\
0\end{array}$ & & $\begin{array}{r}58 \\
82 \\
101 \\
75.5\end{array}$ & $\begin{array}{l}17.7 \\
25.0 \\
30.8 \\
23.0\end{array}$ & $\begin{array}{l}0 \\
0 \\
0 \\
0\end{array}$ & & \\
\hline $\begin{array}{l}\text { Oreg-slough } \\
\text { old Borings } \\
\text { ODOT }\end{array}$ & $\begin{array}{l}991 \\
992 \\
993 \\
994 \\
995 \\
996 \\
997\end{array}$ & $\begin{array}{l}524971 \\
524972 \\
524945 \\
524927 \\
524916 \\
524864 \\
524874\end{array}$ & $\begin{array}{l}5050437 \\
5050406 \\
5050376 \\
5050324 \\
5050251 \\
5050189 \\
5050156\end{array}$ & $\begin{array}{r}28 \\
9 \\
-3 \\
-7 \\
-21 \\
-20 \\
4\end{array}$ & $\begin{array}{r}90 \\
101 \\
71 \\
67 \\
79 \\
89 \\
104\end{array}$ & $\begin{array}{l}-62 \\
-92 \\
-74 \\
-74 \\
-100 \\
-109 \\
-100\end{array}$ & $\begin{array}{r}0 \\
0 \\
0 \\
0 \\
0 \\
-107 \\
0\end{array}$ & $\begin{array}{r}0.0 \\
0.0 \\
0.0 \\
0.0 \\
0.0 \\
-32.6 \\
0.0\end{array}$ & $\begin{array}{l}0 \\
0 \\
0 \\
0 \\
0 \\
1 \\
0\end{array}$ & S\&G & $\begin{array}{r}90 \\
101 \\
71 \\
67 \\
79 \\
87 \\
104\end{array}$ & $\begin{array}{l}27.4 \\
30.8 \\
21.6 \\
20.4 \\
24.1 \\
26.5 \\
31.7\end{array}$ & $\begin{array}{l}0 \\
0 \\
0 \\
0 \\
0 \\
0 \\
0\end{array}$ & & \\
\hline 1205 \& Airport & 998 & 535346 & 5046335 & 21.7 & 74.5 & -52.8 & 0 & 0.0 & 0 & & 74.5 & 22.7 & 0 & & \\
\hline $\begin{array}{l}\text { T 1NR2E 15Badd3 } \\
\text { T INR2E 15Badd1 } \\
\text { T INR2E 15Bbac1 } \\
\text { T INR2E 15Daad1 } \\
\text { T INR2E 15Daaa2 } \\
\text { T INR2E 15Cdaa1 }\end{array}$ & $\begin{array}{r}999 \\
1000 \\
1001 \\
1002 \\
1003 \\
1004\end{array}$ & $\begin{array}{l}535373 \\
535346 \\
534768 \\
536092 \\
536183 \\
535335\end{array}$ & $\begin{array}{l}5046628 \\
5046600 \\
5046951 \\
5046084 \\
5046100 \\
5045656\end{array}$ & $\begin{array}{l}22.14 \\
22.05 \\
22 \\
21.63 \\
21.63 \\
21.86\end{array}$ & $\begin{array}{l}640 \\
228 \\
364 \\
448 \\
270 \\
457\end{array}$ & $\begin{array}{r}-617.86 \\
-205.95 \\
-342 \\
-426.37 \\
-248.37 \\
-435.14\end{array}$ & $\begin{array}{r}-198.86 \\
-197.95 \\
-267 \\
-204.37 \\
-202.37 \\
-9.14\end{array}$ & $\begin{array}{l}-60.6 \\
-60.3 \\
-81.4 \\
-62.3 \\
-61.7 \\
-2.8\end{array}$ & $\begin{array}{l}1 \\
1 \\
1 \\
1 \\
1 \\
1\end{array}$ & $\begin{array}{r}T t \\
S \& G \\
T t \\
T t \\
\text { ofc } \\
T t\end{array}$ & $\begin{array}{r}221 \\
220 \\
289 \\
226 \\
224 \\
31\end{array}$ & $\begin{array}{r}67.4 \\
67.1 \\
88.1 \\
68.9 \\
68.3 \\
9.4\end{array}$ & $\begin{array}{l}0 \\
0 \\
0 \\
0 \\
0 \\
0\end{array}$ & & \\
\hline
\end{tabular}


Hole OalBasal QalBasal GIS Basal Isopach Isopach Ash SPT

T1NR2E14Ddb1

$\begin{array}{ll}1005 & 536325 \\ 1006 & 537680\end{array}$

Eler Ft Depth

Basal

T1NR2E 14Dddb2

5045397

5045485

20

$1007 \quad 537678$

5045484

T1NR2E15Cbaa

1008534926

T1NR2E15Bcac1

$1009 \quad 534820$

5046053

T INR2E 13Cdec2

$1010 \quad 538276$

TINR2E5Cda

5046448

TINR2E90ddc1

1011532025

5045393

TINR2E9Dbdb1

TINR2E15Caac

$\begin{array}{ll}1012 & 534513 \\ 1013 & 534059\end{array}$

TINR2E150 bdb

$1014 \quad 535254$

5048901

$5047016 \quad 20.18$

5047555

5046033

T1NR2E15DbCb1

$1015 \quad 535691$

5045943

TINR2E16Abac1

1016535465

5045849

$534040 \quad 5046748$

TINR2E16Adbc1

TINR2E16ACaC

T1NR2E16CC1

TINR2E 16Cd1

T1NR2E1TDaa

T1NR2E24Bdbd2

T1NR2E24Adcb2

1018534242

1019533766

$5046430 \quad 14.56$

5045575

$533588 \quad 5045614$

$1022 \quad 532973 \quad 5045935$

$1023 \quad 538370 \quad 5044842$

$1024539085 \quad 5044729$

Fremont Bridge

1025

524561

5042300

Smith \& Bybee

Dutch Cones

3rd project

$1026 \quad 520035$

$1027 \quad 520289$

5052570

5052255

5053686

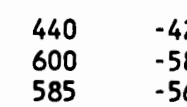

$-420$

$-565$

16
23.9

460

328

-304.1
-548

15

205

$-190$

$-220.82$

423

$-404$

-68.7
-46

-46
-340

$-321.8$

$\begin{array}{rrr}345 & -321.8 & -176.8 \\ 400 & -385.44 & -251.44 \\ 399 & -392 & -236\end{array}$

40

243

$-203$

$-85$

21
17.6

20.1

375

$-357.4$

$\begin{array}{ll}538 & -517.9\end{array}$

-5
-23
-21

$\begin{array}{lll}-5 & -1.5 & 1\end{array}$

Qfe

Feet Meters Code Min Max

Troutdale Airport

$1029 \quad 547668$

5044122

Longview Bridge

$1030 \quad 503036$

1031503007

5105444

Exploration

1032503540

5105399

$\begin{array}{lll}30.9 & 110.9 \quad-80\end{array}$

-60
53.1

$-37$

-88
-141.82

$-113$

$-40$

$\begin{array}{ll}-7.0 & 1 \\ -6.4 & 1\end{array}$

-6.4
-18.3
-77.1

$-77.1$

$-11.3$

$-26.8$

$-43.2$

-34.4
-18.2

$-12.2$

$-10.7$

$-53.9$

$-76.6$

$-71.9$

11.0

12.2

3
0.6

0.9

10.1

3.11

Grvl

S\&G

Grvl

Grvl

Grv

Grvl
S\&G

Grvl

Grvl

Grvl

S\&G

Grvi

Bouldrs

Grv

Tt

Grvl

$\begin{array}{ll}-1.8 & 1\end{array}$

Grvl

Grvl

$\begin{array}{lll}25 & 7.6 & 0\end{array}$

22
13
20

.69

$\begin{array}{ll}-68 & -20.7\end{array}$

$\begin{array}{rrr}-64 & -19.5 & 1 \\ 0 & 0.0 & 0\end{array}$

Grvl

$\begin{array}{lll}-61 & -18.6 \quad 1\end{array}$

Tt

$\begin{array}{lll}-13.1 & 1 & \text { Bouldrs }\end{array}$

$\begin{array}{llll}-43 & -12.8 & 1 & \text { Bouldrs }\end{array}$

Bouldrs

0.90

JOR CON Pasture

John Day River

Bridge

$\begin{array}{ll}1033 & 442812 \\ 1034 & 442084\end{array}$

5112569

-40
-38

$-14.6$

$\begin{array}{lrr}9.5 & 80.5 & -71\end{array}$

$\begin{array}{rrr}0 & 0.0 & 0 \\ -105.2 & -32.1 & 1\end{array}$

Ast Frm

$-29.51$

Ast Frm

$106 \quad 32.3$

$98 \quad 29.9$

ODOT

Tongue $\mathrm{Pt}$. to

$1037 \quad 442667$

5112590

19.8

$98-117.9$

5114141

5114293

-1
-3
0

36

-132
-102

$-119.5$

$-36.4$

Ast Frm

$118.5 \quad 36.1$

$36.5 \quad-36.5$

-73
-7

-22.3
-2.1

Ast Frm

Ast Frm

$\begin{array}{rrr}70 & 21.3 & 0 \\ 7 & 2.1 & 0 \\ 14.5 & 4.4 & 0\end{array}$ 
ODOT

Astoria Bypass

$\begin{array}{ll}1041 & 444562 \\ 1042 & 444324 \\ 1043 & 445337 \\ 1044 & 445125 \\ 1045 & 444903 \\ 1046 & 444708 \\ 1047 & 444392 \\ 1048 & 444190\end{array}$

ODOT

Marys Creek

Bridge

ODOT

Ferris Creek

Bridge

Gnat Creek

Bridge

Blind slough

Bridge

Crown 2

Wauna Or.

Westport Ferry slip

Bradbury slough
Elev Ft Depth Ft Base Ft ContactFt ContactM Code Lithol

12.4

$\begin{array}{ll}99.5 & -87.1 \\ 68.4 & -35.4 \\ 58.3 & -38.3 \\ 48.5 & -51.5 \\ 47.5 & -47.5 \\ 34.8 & -45.8 \\ 70.2 & -74.2 \\ 51.5 & -49.5\end{array}$

-75.6
-17
-19.7
-10
-12.2
-18.8
-21.5
-5.5

-23.0
-5.2
-6.0
-3.0
-3.7
-5.7
-6.6
-1.7

Ast Frm
Ast Frm
Ast Frm
Ast Frm
Ast Frm
Ast Frm
Ast Frm
Ast Frm

5113043
5112938
5112992
5113099
5113078
5113051
5113040
5113010

$\begin{array}{ccc}1049 & 448121 & 5112885 \\ 1050 & 448158 & 5112871 \\ 1051 & 448214 & 5112852 \\ 1052 & 448253 & 5112845\end{array}$

48.5

$\begin{array}{lr}65 & -16.5 \\ 80 & -75 \\ 98 & -93 \\ 98 & -68\end{array}$

48
-42
-51
-40

14.8
-12.8
-15.5
-12.2

Ast $\mathrm{Frm}$

Ast frm

Ast Frm

Ast Frm

$$
\begin{array}{rr}
-7.3 & 1
\end{array}
$$

Ast $\mathrm{Frm}$

$-7.91$

$-8.51$

-7.0
0.0

S\&G

$\begin{array}{rll}-7.0 & 1 & \text { Ast } \mathrm{Frm} \\ -31.4 & 1 & \text { Ast }\end{array}$

-31.41 Ast Frm

Ast Frm

$-43.7$

$\begin{array}{rr}0.0 & 0 \\ -33.9 & 1\end{array}$

0.0

Ast $\mathrm{Frm}$

$\begin{array}{rr}96.5 & -96.5 \\ 111.3 & -111.3\end{array}$

$139.5-139.5$

$-111.3$

$\begin{array}{rr}-28.0 & 1 \\ -1.5 & 1\end{array}$

$108.1-93.1$

26.5
31.6

-16.5
-21.6

$-92$

-2.2
-3.5

3.4

$\begin{array}{rr}41.5 & -31.5 \\ 101.5 & -78.5\end{array}$

156

$-11.5$

11
-14
0

$\begin{array}{rr}-4.3 & 1 \\ 0.0 & 0\end{array}$

0.00

0.00

0.00

0.00

$\begin{array}{ll}0.0 & 0 \\ 0.0 & 0\end{array}$

0.00
S\&G

Bslt

$\begin{array}{lll}88 & 26.8 & 0\end{array}$

$\begin{array}{lll}50 & 15.2 & 0\end{array}$

$39.7 \quad 12.1 \quad 0$

$\begin{array}{rrr}7 & 2.1 & 0\end{array}$

$\begin{array}{rrr}12.2 & 3.7 & 0 \\ 7.8 & 2.4 & 0\end{array}$

$\begin{array}{lll}17.5 & 5.3 & 0\end{array}$

$\begin{array}{lll}7.5 & 2.3 & 0\end{array}$

$\begin{array}{rrr}0 & 0.0 & 0 \\ 47 & 14.3 & 1 \\ 56 & 17.1 & 1\end{array}$

$70 \quad 17.1$

$\begin{array}{lll}29 & 8.8 & 0\end{array}$

$30 \quad 9.1 \quad 0$

$\begin{array}{lll}31 & 9.4 & 0\end{array}$

$\begin{array}{rrr}28 & 8.5 & 0 \\ 5 & 1.5 & 0\end{array}$

$\begin{array}{rrr}33 & 10.1 & 0\end{array}$

$\begin{array}{lll}43.3 & 43.7 & 0\end{array}$

$96.5 \quad 29.4 \quad 1$

$\begin{array}{ll}111.3 & 33.9 \\ 139.5 & 42.0\end{array}$

Bslt $\quad 107 \quad 32.6 \quad 0$

$\begin{array}{rrrr}\text { Qls } & 15 & 4.6 & 0 \\ \text { Grvl } & 17.3 & 5.3 & 0\end{array}$

Grvl $21.5 \quad 6.6 \quad 00177$

Qls

$\begin{array}{ll}12.5 & 6.6 \\ 12 & 3.7\end{array}$

$\begin{array}{rrr}25 & 3.7 & 0 \\ 70 & 7.6 & 0\end{array}$

$150 \quad 45.7$

$\begin{array}{lll}150 & 45.7 & 1\end{array}$

$\begin{array}{lll}150 & 45.7 & 1 \\ 150 & 45.7 & 0\end{array}$

$149.5 \quad 45.6 \quad 0$

$\begin{array}{lll}74.5 & 22.7 & 0\end{array}$ 

Elev Ft Depth Ft Base Ft Contactft ContactM Code Lithol Feet Meters Code Min Max

HASHDOT

Puget is
Bridge

WASHDOT

Deep River

Bridge

Ranglia Slough

Bridge

Port Westward Beaver Site

$\begin{array}{lll}1077 & 487139 & 5113700 \\ 1078 & 487592 & 511348 \\ 1079 & 487541 & 5113240 \\ 1080 & 487838 & 511317 \\ 1081 & 487997 & 511303\end{array}$

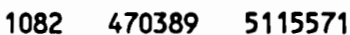

$\begin{array}{lll}1083 & 470331 & 5115479\end{array}$

$1084 \quad 470331 \quad 5115414$

$\begin{array}{lll}1085 & 470318 & 5115347\end{array}$

$\begin{array}{lll}1086 & 470314 & 5115287\end{array}$

$\begin{array}{lll}1087 \quad 470334 & 5115218\end{array}$

$\begin{array}{lll}1088 & 470347 & 5115182\end{array}$

$1089 \quad 470360 \quad 5115148$

$1090 \quad 470391 \quad 5115108$

$1091 \quad 445796 \quad 5131456$

$\begin{array}{ll}1092 & 445904 \\ 1093 & 445949\end{array}$

$1094 \quad 445951$

1095445995

$1096 \quad 446023$

$1097 \quad 446062$

$1098 \quad 446101$

$1099 \quad 446141$

$1100 \quad 446171$

$1101 \quad 446202$

$1102 \quad 446211$

1103446250

$1104 \quad 446284$

$1105 \quad 446325$

$1106 \quad 446339$

$1107 \quad 446352$

$1108 \quad 446642$

$1109 \quad 446645$

$1110 \quad 446648$

1111446650

1112486145

$1113 \quad 486269$

$1114 \quad 486422$

5131401
5131378

5131378

5131360

5131340

5131321

5131310

5131296

5131282

5131283

5131267

5131249

5131234

5131215

5131231

5131210

5130958

5130939

5130917

5130896

5113179

5113227

$\begin{array}{lll}0 & 78.5 & -78.5 \\ 0 & 73.5 & -73.5 \\ 0 & 67.5 & -67.5 \\ 0 & 88.5 & -88.5 \\ 0 & 62.5 & -62.5\end{array}$

$\begin{array}{lll}-21 & 212 & -233\end{array}$

$-17$

$-19$

$\begin{array}{rr}212 & -233 \\ 201.5 & -218.5 \\ 201.5 & -220.5\end{array}$

$-220.5$

$200.25-225.5$

$\begin{array}{rrr}-2 & 200 & -202 \\ -2 & 200 & -199\end{array}$

$\begin{array}{rrr}-2 & 200 & -202 \\ 1 & 200 & -199\end{array}$

$\begin{array}{lll}5 & 267 & -262 \\ 5 & 117 & -112\end{array}$

$\begin{array}{lll}8.4 & 41.5 & -33.1\end{array}$

$\begin{array}{rrr}31 & 36.5 & -5.5 \\ 16.9 & 91 & -74.1\end{array}$

$\begin{array}{lll}16 & 110 & -94\end{array}$

$115-109$

189

248

-125
-184

$-241$

$214.5-222.5$

$221.33-229.33$

8.8

240.33

229.33
231.53

245

$257 \quad-252$

$253.5-247.5$

$-247.5$

245

-173
-242

4
-8
9

245

$-241$

$244-252$

$\begin{array}{rr}236 & -227 \\ 91.5 & -82.7\end{array}$

5113284
13.5

$\begin{array}{ll}135 & -121.5\end{array}$

14
12.5

$\begin{array}{lll}0 & 0.0 & 0 \\ 0 & 0.0 & 0 \\ 0 & 0.0 & 0 \\ 0 & 0.0 & 0 \\ 0 & 0.0 & 0\end{array}$

0.00

0.00

$0.0 \quad 0$

0.00

$0.0 \quad 0$

$\begin{array}{ll}0.0 & 0 \\ 0.0 & 0\end{array}$

$0.0 \quad 0$

0.00

$\begin{array}{rr}0.0 & 0 \\ -14.7 & 1\end{array}$

$-18.0$

$-23.3$

$-29.3$

$-49.4$

$-65.4$

$-57.3$

$-64.4$

-64.3
-65.7

$-67.7$

-66.1
0.0

$-65.5$

$-62.8$

.67 .41 Ast Frm

-65.21 Ast Frm

0.00

0.00

0.00

0.00

Ast Frm

Ast Frm

Ast Frm

Ast Frm

Arm

Grvl

Ast Frm

Ast Frm
Ast Frm

Ast $\mathrm{Frm}$

Ast Frm

Ast Frm

Ast Frm $\begin{array}{lll}78.5 & 23.9 & 0 \\ 73.5 & 22.4 & 0 \\ 67.5 & 20.6 & 0 \\ 88.5 & 27.0 & 0 \\ 62.5 & 19.1 & 0\end{array}$

$\begin{array}{lllll}212 & 64.6 & 0 & 1 & 126\end{array}$

$\begin{array}{rrrrr}201.5 & 61.4 & 0 & 4 & 108\end{array}$

01108

$\begin{array}{lllll}200.25 & 61.0 & 0 & 2 & 129\end{array}$

$\begin{array}{lllll}200 & 61.0 & 0 & 1 & 91\end{array}$

$\begin{array}{lllll}200 & 61.0 & 0 & 1 & 76\end{array}$

$\begin{array}{lllll}267 & 81.4 & 0 & 4 & 62 \\ 117 & 35.7 & 0 & 3 & 27\end{array}$

$\begin{array}{lll}41.5 & 12.6 & 0\end{array}$

$\begin{array}{lll}36.5 & 11.1 & 0\end{array}$

$65 \quad 19.8$

$\begin{array}{ll}75 & 22.9\end{array}$

$82.5 \quad 25.1$

$\begin{array}{ll}100 & 30.5 \\ 167 & 50.9\end{array}$

22267.7

$214.5 \quad 65.4$

22067.1

21565.5

$19.5 \quad 66.9$

$227 \quad 69.2$

$\begin{array}{ll}223 & 68.0 \\ 180 & 54.9\end{array}$

$\begin{array}{ll}180 & 54.9 \\ 218 & 66.4\end{array}$

$210 \quad 640$

$\begin{array}{llll}213 & 64.9 & 0 & 1\end{array}$

$\begin{array}{rrrrr}223 & 68.0 & 0 & 3 & 37 \\ 91.5 & 27.9 & 1 & 2 & 50\end{array}$

$\begin{array}{lll}135 & 41.1 \quad 1\end{array}$

$\begin{array}{lll}111 & 33.8 & 0 . \\ 114 & 34.7 & 1\end{array}$ 

Elev Ft Depth Ft Base Ft Contactft ContactM Code Lithol Feet Meters Code Min Max

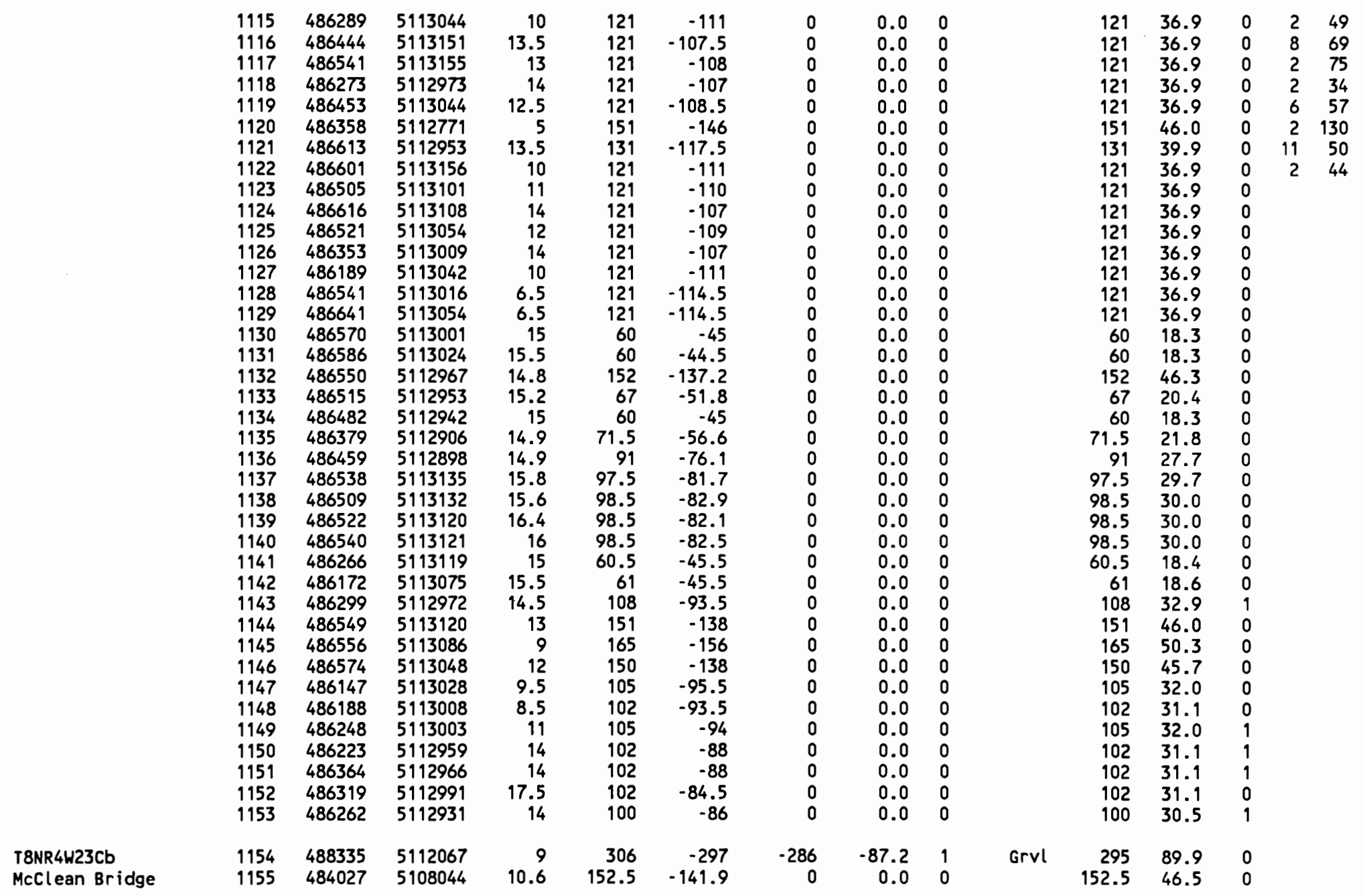


Hole QalBasal QalBasal GIS Basal Isopach Isopach Ash SPT

Oak Pt/locoda

PGE Crossing

Elev

Depth Ft Base Ft ContactFt ContactM Code Lithol

Feet Meters Ash SPT

* Geophysical

$\begin{array}{lll}1157 & 486461 & 5114815\end{array}$

Contact

$486455 \quad 5114886$

$\begin{array}{rrr}19.2 & 76.5 & -57.3 \\ 21.3 & 151.5 & -130.2\end{array}$

$\begin{array}{rrr}21.3 & 151.5 & -130.2 \\ 20.8 & 101.5 & -80.7\end{array}$

$-371.2$

$\begin{array}{cccc}.2^{*} & -113.1 * & 1 & \text { afc/Tt? } \\ 0 & 0.0 & 0 & \\ 0 & 0.0 & 0 & \end{array}$

$\begin{array}{rrr}375 & 114.3 & 1\end{array}$

23.

$\begin{array}{ll}.5 & -80.7 \\ & -1.2\end{array}$

$\begin{array}{ccc}0.0 & 0.0 & 0 \\ -9.0 & 0.0 & 0\end{array}$

$101.5 \quad 30.9 \quad 1$

T8NR4W27Ad

5110714

Powers slough

Bridge

Skippanon Bridge

Warrenton Or

Holbrook Slough

Warrenton Or.

Astoria Pier 3

1161

$1162 \quad 428361$

5114162

15

$128-113$

$-1$

$-28.9 *$

Qfc/Tt?

$\begin{array}{lll}119 & 36.2 & 0\end{array}$

$1163 \quad 429023 \quad 5112601$

$\begin{array}{lll}1164 & 428939 & 5112593\end{array}$

$\begin{array}{rrr}5 & 142.5 & -137.5 \\ 5 & 83.5 & -78.5\end{array}$$$
-136
$$

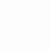

-0.31 Ast Frm

$\begin{array}{lll}16 & 4.9 & 0\end{array}$

$\begin{array}{lll}10.5 & 102 \quad-91.5\end{array}$

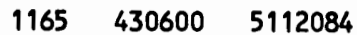

$\begin{array}{lll}1166 & 430547 \quad 5112038\end{array}$

9.8

99.5

$-89.7$

(1)

$\begin{array}{rr}-41.5 & 1 \\ 0.0 & 0\end{array}$

S\&G

$\begin{array}{rrr}141 & 43.0 & 0 \\ 83.5 & 25.5 & 0\end{array}$

$\begin{array}{rrr}102 & 31.1 & 1\end{array}$

$\begin{array}{rrr}120.5 & 36.7 & 1\end{array}$

$\begin{array}{lllll}91.5 & -86.5 & 0 & 0.0 & 0 \\ & & 0.0 & 0\end{array}$

$\begin{array}{lll}91.5 & 27.9 & 0\end{array}$

$\begin{array}{lll}1167 & 433380 & 5115032\end{array}$

$1169 \quad 433276$

$\begin{array}{lll}1170 \quad 433319 & 5115022\end{array}$

Astoria Pier 2

1179433506

5115276

$1172 \quad 433662$

$1173 \quad 433762$

5115185

5115093

5115109

10
10

10
10

$\begin{array}{rr}55 & -45 \\ 79 & -69 \\ 97.5 & -87.5\end{array}$

$\begin{array}{rr}901.3 & -191.3\end{array}$

0
0
0
-155

0.00

0.00

0.0
-47.2

Ast Frm

$\begin{array}{lll}55 & 16.8 & 0\end{array}$

$\begin{array}{rrr}79 & 24.1 & 0 \\ 97.5 & 29.7 & 0\end{array}$

$\begin{array}{lll}-14 & 151.5 & -165.5\end{array}$

$\begin{array}{lll}-20.5 & 125.5 & -146\end{array}$

$\begin{array}{rr}30.7 & -45.2\end{array}$

OOOT

Astoria-Megler

$\begin{array}{lll}1175 & 432686 & 5120876 \\ 1176 & 432742 & 5120706\end{array}$

$1177 \quad 432779 \quad 5120604$

Bridge

-38
-55
-67
-64
-37.5
-23
-10.5
-10.5
-36
-47
-48
-47
-23
-21
12

$\begin{array}{rr}36 & -74 \\ 99 & -154 \\ 127.5 & -194.5 \\ 102 & -166 \\ 122.5 & -160 \\ 84 & -107 \\ 107.5 & -118 \\ 98.5 & -109 \\ 148 & -184 \\ 151 & -198 \\ 224 & -272 \\ 209 & -256 \\ 114 & -137 \\ 159 & -180 \\ 54 & -42\end{array}$

0

$0.0 \quad 0$

0.00

$\begin{array}{ll}0.0 & 0 \\ 0.0 & 0\end{array}$

$\begin{array}{lll}151.5 & 46.2 & 0\end{array}$

$125.5 \quad 38.3 \quad 0$

$\begin{array}{rrr}30.7 & 9.4 & 0 \\ 86.5 & 26.4 & 0\end{array}$

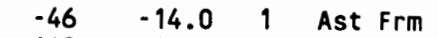

$\begin{array}{lll}-149 & -45.4 & 1\end{array}$ Ast Frm

$\begin{array}{lll}-204 & -62.2 & 1\end{array}$ Ast Frm

$\begin{array}{rrr}8 & 2.4 & 0 \\ 94 & 28.7 & 0\end{array}$

$\begin{array}{lll}127.5 & 38.9 & 0\end{array}$

$\begin{array}{rrr}102 & 31.1 & 0 \\ 122.5 & 37.3 & 0\end{array}$

$8425.6 \quad 0$

$\begin{array}{rrr}84 & 25.6 & 0 \\ 107.5 & 32.8 & 0\end{array}$

$98.5 \quad 30.0 \quad 0$

$\begin{array}{lll}148 & 45.1 & 0\end{array}$

$\begin{array}{rrrllll}0 & 0.0 & 0 & & 151 & 46.0 & 0 \\ -230 & -70.1 & 1 & \text { Ast Frm } & 182 & 55.5 & 0 \\ -238 & -72.5 & 1 & \text { Ast Frm } & 191 & 58.2 & 0\end{array}$

$\begin{array}{lllllll}-238 & -72.5 & 1 & \text { Ast Frm } & 191 & 58.2 & 0 \\ -123 & -37.5 & 1 & \text { Ast Frm } & 100 & 30.5 & 0\end{array}$

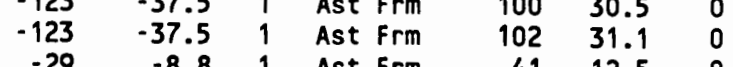


Elev Ft Depth Ft Base Ft ContactFt ContactM Code Lithol Feet Meters Code Min Max

\begin{tabular}{|c|c|c|c|c|c|c|c|c|c|c|c|c|}
\hline & $\begin{array}{l}1190 \\
1191\end{array}$ & $\begin{array}{l}434561 \\
434582\end{array}$ & $\begin{array}{l}5115304 \\
5115239\end{array}$ & $\begin{array}{l}11.5 \\
18.5\end{array}$ & $\begin{array}{l}46.5 \\
43.5\end{array}$ & $\begin{array}{l}-35 \\
-25\end{array}$ & $\begin{array}{l}-20 \\
-16\end{array}$ & $\begin{array}{l}-6.1 \\
-4.9\end{array}$ & $\begin{array}{l}1 \\
1\end{array}$ & $\begin{array}{l}\text { Ast } \mathrm{Frm} \\
\text { Ast } \mathrm{Frm}\end{array}$ & $\begin{array}{l}31.5 \\
34.5\end{array}$ & $\begin{array}{r}9.6 \\
10.5\end{array}$ \\
\hline $\begin{array}{l}\text { John Day River } \\
\text { Bridge }\end{array}$ & $\begin{array}{l}1192 \\
1193 \\
1194 \\
1195 \\
1196 \\
1197 \\
1198 \\
1199 \\
1200 \\
1201 \\
1202\end{array}$ & $\begin{array}{l}442086 \\
441979 \\
441929 \\
441957 \\
441881 \\
441870 \\
441855 \\
441836 \\
441811 \\
441888 \\
442036\end{array}$ & $\begin{array}{l}5112598 \\
5112673 \\
5112702 \\
5112684 \\
5112744 \\
5112758 \\
5112777 \\
5112802 \\
5112826 \\
5112716 \\
5112609\end{array}$ & $\begin{array}{r}4.2 \\
4 \\
-22 \\
-16 \\
11 \\
11 \\
11 \\
16 \\
16 \\
6.51 \\
4.6\end{array}$ & $\begin{array}{r}121 \\
112 \\
82 \\
84 \\
80 \\
70 \\
53 \\
68 \\
63 \\
96 \\
121\end{array}$ & $\begin{array}{r}-116.8 \\
-108 \\
-104 \\
-100 \\
-69 \\
-59 \\
-42 \\
-52 \\
-47 \\
-89.49 \\
-116.4\end{array}$ & $\begin{array}{r}-125.8 \\
-72 \\
-88 \\
-68 \\
-54 \\
-47 \\
-37 \\
-51 \\
-42 \\
-43.49 \\
-80.4\end{array}$ & $\begin{array}{l}-38.3 \\
-21.9 \\
-26.8 \\
-20.7 \\
-16.5 \\
-14.3 \\
-11.3 \\
-15.5 \\
-12.8 \\
-13.3 \\
-24.5\end{array}$ & $\begin{array}{l}1 \\
1 \\
1 \\
1 \\
1 \\
1 \\
1 \\
1 \\
1 \\
1 \\
1\end{array}$ & $\begin{array}{l}\text { Ast } \mathrm{Frm} \\
\text { Ast } \mathrm{Frm} \\
\text { Ast } \mathrm{Frm} \\
\text { Ast } \mathrm{Frm} \\
\text { Ast } \mathrm{Frm} \\
\text { Ast } \mathrm{Frm} \\
\text { Ast } \mathrm{Frm} \\
\text { Ast } \mathrm{Frm} \\
\text { Ast } \mathrm{Frm} \\
\text { Ast } \mathrm{Frm} \\
\text { Ast } \mathrm{Frm}\end{array}$ & $\begin{array}{r}121 \\
76 \\
66 \\
52 \\
65 \\
58 \\
48 \\
67 \\
58 \\
50 \\
85\end{array}$ & $\begin{array}{l}36.9 \\
23.2 \\
20.1 \\
15.8 \\
19.8 \\
17.7 \\
14.6 \\
20.4 \\
17.7 \\
15.2 \\
25.9\end{array}$ \\
\hline $\begin{array}{l}\text { T8NR 10W9Bb1 } \\
\text { T8NR 10W9Cb1 } \\
\text { T8NR10W7Ad }\end{array}$ & $\begin{array}{l}1203 \\
1204 \\
1205\end{array}$ & $\begin{array}{l}427428 \\
428565 \\
425763\end{array}$ & $\begin{array}{l}5116140 \\
5115448 \\
5116334\end{array}$ & $\begin{array}{l}10 \\
10 \\
23\end{array}$ & $\begin{array}{r}369 \\
1539 \\
800\end{array}$ & $\begin{array}{r}-359 \\
-1529 \\
-777\end{array}$ & $\begin{array}{l}-278 \\
-252 \\
-258\end{array}$ & $\begin{array}{l}-84.7 \\
-76.8 \\
-78.6\end{array}$ & $\begin{array}{l}1 \\
1 \\
1\end{array}$ & $\begin{array}{l}\text { Ast frm } \\
\text { Ast Frm } \\
\text { Ast Frm }\end{array}$ & $\begin{array}{l}288 \\
262 \\
281\end{array}$ & $\begin{array}{l}87.8 \\
79.9 \\
85.6\end{array}$ \\
\hline Col. Co. School & 1206 & 479015 & 5106204 & 32 & 125 & -93 & 30 & 9.1 & 1 & Grvl & 2 & 0.6 \\
\hline T7NR5W3 & 1207 & 477858 & 5106449 & 14 & 42 & -28 & -27 & -8.2 & 1 & Ast $\mathrm{Frm}$ & 41 & 12.5 \\
\hline Woodson Bridge & $\begin{array}{l}1208 \\
1209\end{array}$ & $\begin{array}{l}474911 \\
474933\end{array}$ & $\begin{array}{l}5106741 \\
5106794\end{array}$ & $\begin{array}{l}3 \\
4\end{array}$ & $\begin{array}{l}65 \\
65\end{array}$ & $\begin{array}{l}-62 \\
-61\end{array}$ & $\begin{array}{l}0 \\
0\end{array}$ & $\begin{array}{l}0.0 \\
0.0\end{array}$ & $\begin{array}{l}0 \\
0\end{array}$ & & $\begin{array}{l}65 \\
65\end{array}$ & $\begin{array}{l}19.8 \\
19.8\end{array}$ \\
\hline $\begin{array}{l}\text { Tennasille } \\
\text { Island }\end{array}$ & $\begin{array}{l}1210 \\
1211 \\
1212 \\
1213 \\
1214 \\
1215\end{array}$ & $\begin{array}{l}463845 \\
463768 \\
463604 \\
463600 \\
463628 \\
463400\end{array}$ & $\begin{array}{l}5120263 \\
5120251 \\
5120141 \\
5120091 \\
5120177 \\
5119981\end{array}$ & $\begin{array}{l}11.5 \\
11.5 \\
11.5 \\
11.5 \\
11.5 \\
11.5\end{array}$ & $\begin{array}{l}38.5 \\
29.5 \\
38.5 \\
28.5 \\
30.5 \\
31.5\end{array}$ & $\begin{array}{l}-27 \\
-18 \\
-27 \\
-17 \\
-19 \\
-20\end{array}$ & $\begin{array}{l}0 \\
0 \\
0 \\
0 \\
0 \\
0\end{array}$ & $\begin{array}{l}0.0 \\
0.0 \\
0.0 \\
0.0 \\
0.0 \\
0.0\end{array}$ & $\begin{array}{l}0 \\
0 \\
0 \\
0 \\
0 \\
0\end{array}$ & & $\begin{array}{l}38.5 \\
29.5 \\
38.5 \\
28.5 \\
30.5 \\
31.5\end{array}$ & $\begin{array}{r}11.7 \\
9.0 \\
11.7 \\
8.7 \\
9.3 \\
9.6\end{array}$ \\
\hline $\begin{array}{l}\text { T9NR6W26CCa } \\
\text { T9NR6W26Ad } \\
\text { T9NR6W26Cb } \\
\text { T9NR6W18Aa } \\
\text { T9NR6W5Ad } \\
\text { T10NR11W26Ba } \\
\text { T10NR11H26Ca }\end{array}$ & $\begin{array}{l}1216 \\
1217 \\
1218 \\
1219 \\
1220 \\
1221 \\
1222\end{array}$ & $\begin{array}{l}469376 \\
470565 \\
469703 \\
464398 \\
465884 \\
422645 \\
422496\end{array}$ & $\begin{array}{l}5119732 \\
5120382 \\
5119879 \\
5123902 \\
5126567 \\
5130908 \\
5130071\end{array}$ & $\begin{array}{l}14 \\
10 \\
10 \\
10 \\
20 \\
20 \\
20\end{array}$ & $\begin{array}{r}40 \\
64 \\
59 \\
120 \\
130 \\
17 \\
93.5\end{array}$ & $\begin{array}{r}-26 \\
-54 \\
-49 \\
-110 \\
-110 \\
3 \\
-73.5\end{array}$ & $\begin{array}{r}0 \\
-48 \\
0 \\
-110 \\
-100 \\
0 \\
0\end{array}$ & $\begin{array}{r}0.0 \\
-14.6 \\
0.0 \\
-33.5 \\
-30.5 \\
0.0 \\
0.0\end{array}$ & $\begin{array}{l}0 \\
1 \\
0 \\
1 \\
1 \\
0 \\
0\end{array}$ & $\begin{array}{l}\text { Grvl } \\
\text { Bslt } \\
\text { Grvl }\end{array}$ & $\begin{array}{r}40 \\
58 \\
59 \\
120 \\
120 \\
17 \\
93.5\end{array}$ & $\begin{array}{r}12.2 \\
17.7 \\
18.0 \\
36.6 \\
36.6 \\
5.2 \\
28.5\end{array}$ \\
\hline
\end{tabular}




\begin{tabular}{|c|c|c|c|c|c|c|c|c|c|c|c|c|c|c|c|}
\hline $\begin{array}{l}\text { New England } \\
\text { Fish Co. }\end{array}$ & $\begin{array}{l}1223 \\
1224 \\
1225\end{array}$ & $\begin{array}{l}429351 \\
429440 \\
429410\end{array}$ & $\begin{array}{l}5113081 \\
5113094 \\
5113169\end{array}$ & $\begin{array}{r}7 \\
7 \\
10\end{array}$ & $\begin{array}{l}65 \\
57 \\
62\end{array}$ & $\begin{array}{l}-58 \\
-50 \\
-52\end{array}$ & $\begin{array}{l}0 \\
0 \\
0\end{array}$ & $\begin{array}{l}0.0 \\
0.0 \\
0.0\end{array}$ & $\begin{array}{l}0 \\
0 \\
0\end{array}$ & & $\begin{array}{l}65 \\
57 \\
62\end{array}$ & $\begin{array}{l}19.8 \\
17.4 \\
18.9\end{array}$ & $\begin{array}{l}0 \\
0 \\
0\end{array}$ & & \\
\hline $\begin{array}{l}\text { NW Aluminum } \\
\text { Warrenton Or. }\end{array}$ & $\begin{array}{l}1226 \\
1227 \\
1228 \\
1229 \\
1230 \\
1231 \\
1232 \\
1233 \\
1234 \\
1235\end{array}$ & $\begin{array}{l}429963 \\
429993 \\
429895 \\
429928 \\
428753 \\
428658 \\
429526 \\
429513 \\
429804 \\
430548\end{array}$ & $\begin{array}{l}5113788 \\
5112862 \\
5112141 \\
5111575 \\
5111298 \\
5112030 \\
5112456 \\
5111827 \\
5113284 \\
5113370\end{array}$ & $\begin{array}{r}0 \\
5 \\
10 \\
10 \\
10 \\
10 \\
10 \\
10 \\
5 \\
0\end{array}$ & $\begin{array}{r}111 \\
101 \\
101 \\
75 \\
52 \\
102 \\
102 \\
101 \\
101 \\
101\end{array}$ & $\begin{array}{r}-111 \\
-96 \\
-91 \\
-65 \\
-42 \\
-92 \\
-92 \\
-91 \\
-96 \\
-101\end{array}$ & $\begin{array}{r}0 \\
0 \\
0 \\
-58 \\
-31 \\
0 \\
0 \\
0 \\
0 \\
0\end{array}$ & $\begin{array}{r}0.0 \\
0.0 \\
0.0 \\
-17.7 \\
-9.4 \\
0.0 \\
0.0 \\
0.0 \\
0.0 \\
0.0\end{array}$ & $\begin{array}{l}0 \\
0 \\
0 \\
1 \\
1 \\
0 \\
0 \\
0 \\
0 \\
0\end{array}$ & $\begin{array}{l}\text { Ast } \mathrm{Frm} \\
\text { Ast } \mathrm{Frm}\end{array}$ & $\begin{array}{r}111 \\
101 \\
101 \\
68 \\
41 \\
102 \\
102 \\
101 \\
101 \\
101\end{array}$ & $\begin{array}{l}33.8 \\
30.8 \\
30.8 \\
20.7 \\
12.5 \\
31.1 \\
31.1 \\
30.8 \\
30.8 \\
30.8\end{array}$ & $\begin{array}{l}0 \\
0 \\
1 \\
0 \\
0 \\
1 \\
1 \\
1 \\
0 \\
0\end{array}$ & 7 & 170 \\
\hline $\begin{array}{l}\text { Astoria Pier } 3 \\
\text { 2nd project }\end{array}$ & $\begin{array}{l}1236 \\
1237 \\
1238\end{array}$ & $\begin{array}{l}433269 \\
433018 \\
432892\end{array}$ & $\begin{array}{l}5115246 \\
5115146 \\
5115147\end{array}$ & $\begin{array}{r}-19 \\
-20 \\
-29.5\end{array}$ & $\begin{array}{l}125 \\
126 \\
119\end{array}$ & $\begin{array}{r}-144 \\
-146 \\
-148.5\end{array}$ & $\begin{array}{l}0 \\
0 \\
0\end{array}$ & $\begin{array}{l}0.0 \\
0.0 \\
0.0\end{array}$ & $\begin{array}{l}0 \\
0 \\
0\end{array}$ & & $\begin{array}{l}125 \\
126 \\
119\end{array}$ & $\begin{array}{l}38.1 \\
38.4 \\
36.3\end{array}$ & $\begin{array}{l}0 \\
0 \\
0\end{array}$ & & $\begin{array}{l}100 \\
110 \\
128\end{array}$ \\
\hline Tongue Point & $\begin{array}{l}1239 \\
1240 \\
1241 \\
1242 \\
1243 \\
1244 \\
1245 \\
1246 \\
1247 \\
1248 \\
1249 \\
1250\end{array}$ & $\begin{array}{l}441386 \\
441365 \\
441221 \\
441164 \\
441240 \\
441285 \\
441311 \\
441266 \\
441227 \\
441064 \\
441333 \\
441393\end{array}$ & $\begin{array}{l}5115987 \\
5116028 \\
5115956 \\
5116446 \\
5116356 \\
5116259 \\
5116159 \\
5116041 \\
5116095 \\
5116502 \\
5115975 \\
5115838\end{array}$ & $\begin{array}{l}15 \\
15 \\
15 \\
15 \\
15 \\
15 \\
15 \\
15 \\
15 \\
15 \\
15 \\
15\end{array}$ & $\begin{array}{r}59.5 \\
56.5 \\
21.5 \\
31.5 \\
36.5 \\
32 \\
35 \\
31.5 \\
20 \\
25 \\
35 \\
31.5\end{array}$ & $\begin{array}{r}-44.5 \\
-41.5 \\
-6.5 \\
-16.5 \\
-21.5 \\
-17 \\
-20 \\
-16.5 \\
-5 \\
-10 \\
-20 \\
-16.5\end{array}$ & $\begin{array}{l}0 \\
0 \\
0 \\
0 \\
0 \\
0 \\
0 \\
0 \\
0 \\
0 \\
0 \\
0\end{array}$ & $\begin{array}{l}0.0 \\
0.0 \\
0.0 \\
0.0 \\
0.0 \\
0.0 \\
0.0 \\
0.0 \\
0.0 \\
0.0 \\
0.0 \\
0.0\end{array}$ & $\begin{array}{l}0 \\
0 \\
0 \\
0 \\
0 \\
0 \\
0 \\
0 \\
0 \\
0 \\
0 \\
0\end{array}$ & & $\begin{array}{r}59.5 \\
56.5 \\
21.5 \\
31.5 \\
36.5 \\
32 \\
35 \\
31.5 \\
20 \\
25 \\
35 \\
31.5\end{array}$ & $\begin{array}{r}18.1 \\
17.2 \\
6.6 \\
9.6 \\
11.1 \\
9.8 \\
10.7 \\
9.6 \\
6.1 \\
7.6 \\
10.7 \\
9.6\end{array}$ & $\begin{array}{l}0 \\
0 \\
0 \\
0 \\
0 \\
0 \\
0 \\
0 \\
0 \\
0 \\
0 \\
0\end{array}$ & & \\
\hline $\begin{array}{l}\text { Tongue Point } \\
\text { 2nd project }\end{array}$ & $\begin{array}{l}1251 \\
1252 \\
1253 \\
1254 \\
1255 \\
1256 \\
1257\end{array}$ & $\begin{array}{l}441248 \\
441542 \\
441436 \\
441678 \\
441299 \\
441434 \\
441473\end{array}$ & $\begin{array}{l}5116554 \\
5116486 \\
5116582 \\
5116574 \\
5116381 \\
5116421 \\
5116263\end{array}$ & $\begin{array}{r}-15.5 \\
-10 \\
-11.5 \\
-11.5 \\
-15 \\
-13.5 \\
-13.5\end{array}$ & $\begin{array}{r}17 \\
19.5 \\
20.5 \\
18 \\
13 \\
14 \\
19\end{array}$ & $\begin{array}{r}-32.5 \\
-29.5 \\
-32 \\
-29.5 \\
-28 \\
-27.5 \\
-32.5\end{array}$ & $\begin{array}{l}0 \\
0 \\
0 \\
0 \\
0 \\
0 \\
0\end{array}$ & $\begin{array}{l}0.0 \\
0.0 \\
0.0 \\
0.0 \\
0.0 \\
0.0 \\
0.0\end{array}$ & $\begin{array}{l}0 \\
0 \\
0 \\
0 \\
0 \\
0 \\
0\end{array}$ & & $\begin{array}{r}17 \\
19.5 \\
20.5 \\
18 \\
13 \\
14 \\
19\end{array}$ & $\begin{array}{l}5.2 \\
5.9 \\
6.2 \\
5.5 \\
4.0 \\
4.3 \\
5.8\end{array}$ & $\begin{array}{l}0 \\
0 \\
0 \\
0 \\
0 \\
0 \\
0\end{array}$ & & \\
\hline $\begin{array}{l}\text { Tongue Point } \\
\text { 3rd project }\end{array}$ & $\begin{array}{l}1258 \\
1259\end{array}$ & $\begin{array}{l}441290 \\
441382\end{array}$ & $\begin{array}{l}5116466 \\
5116497\end{array}$ & $\begin{array}{r}-12.5 \\
-16\end{array}$ & $\begin{array}{r}48 \\
47.5\end{array}$ & $\begin{array}{l}-60.5 \\
-63.5\end{array}$ & $\begin{array}{l}-21 \\
-29\end{array}$ & $\begin{array}{l}-6.4 \\
-8.8\end{array}$ & $\begin{array}{l}1 \\
1\end{array}$ & $\begin{array}{l}\text { Ast Frm } \\
\text { Ast Frm }\end{array}$ & $\begin{array}{r}8.5 \\
13\end{array}$ & $\begin{array}{l}2.6 \\
4.0\end{array}$ & $\begin{array}{l}0 \\
0\end{array}$ & & \\
\hline
\end{tabular}

Elev Ft Depth Ft Base Ft Contactft ContactM Code Lithol Feet Meters Code Min Max 
Elev Ft Depth Ft Base Ft Contactft ContactM Code Lithol Feet Meters Code Min Max

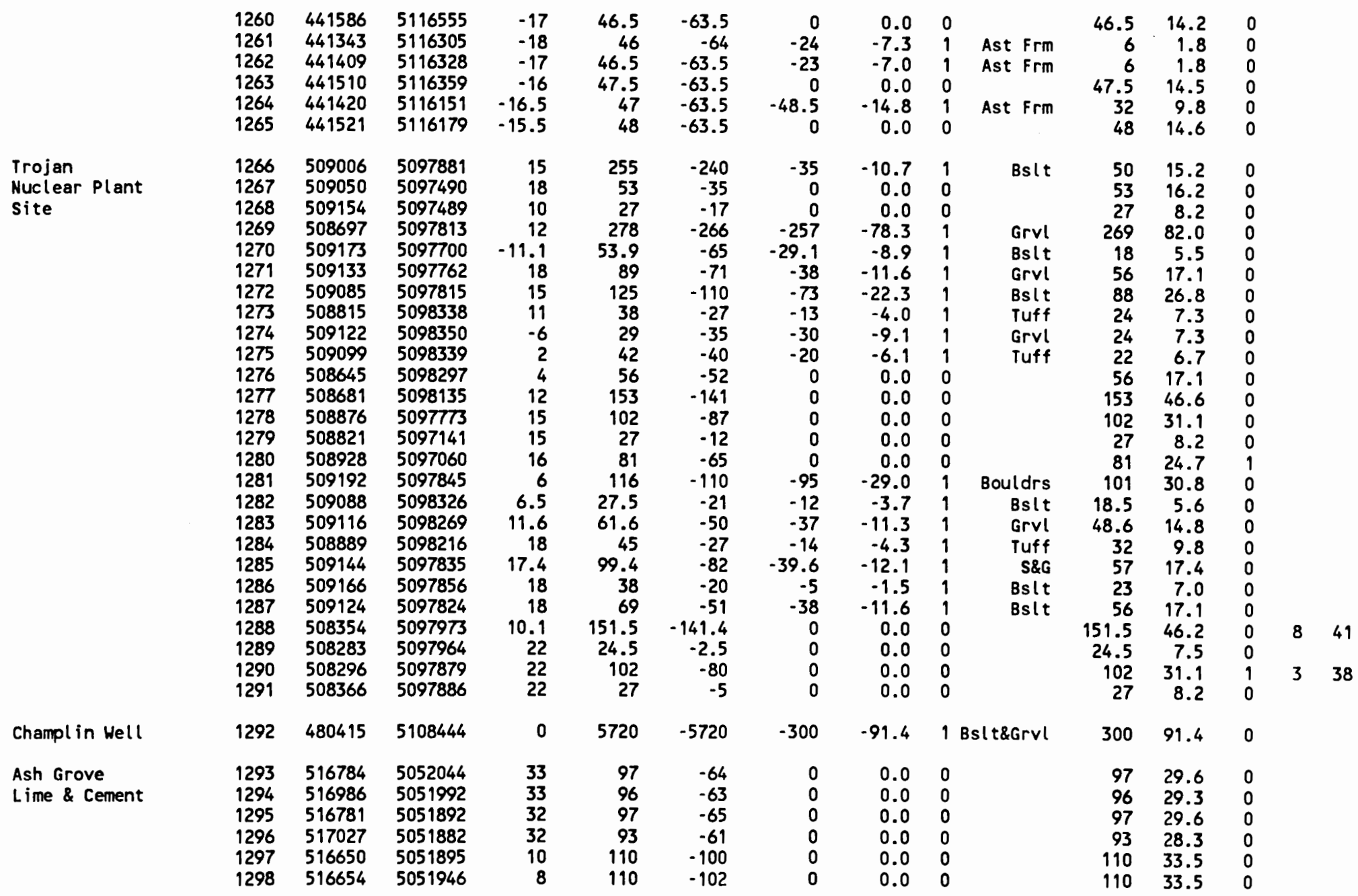


Elev Ft Depth Ft Base Ft Contactft ContactM Code Lithol Feet Meters Code Min Max

\begin{tabular}{|c|c|c|c|c|c|c|c|c|c|c|c|c|c|c|c|}
\hline Ash Grove Hell & $\begin{array}{l}1299 \\
1300 \\
1301 \\
1302\end{array}$ & $\begin{array}{l}516662 \\
516869 \\
516935 \\
516781\end{array}$ & $\begin{array}{l}5051991 \\
5051981 \\
5051972 \\
5051966\end{array}$ & $\begin{array}{r}8 \\
34 \\
34 \\
32.0\end{array}$ & $\begin{array}{r}91 \\
76 \\
71 \\
212.0\end{array}$ & $\begin{array}{r}-83 \\
-42 \\
-37 \\
-180.0\end{array}$ & $\begin{array}{r}0 \\
0 \\
0 \\
-158.0\end{array}$ & $\begin{array}{r}0.0 \\
0.0 \\
0.0 \\
-48.2\end{array}$ & $\begin{array}{l}0 \\
0 \\
0 \\
1\end{array}$ & $T t$ & $\begin{array}{r}91 \\
76 \\
71 \\
190.0\end{array}$ & $\begin{array}{l}27.7 \\
23.2 \\
21.6 \\
57.9\end{array}$ & $\begin{array}{l}0 \\
0 \\
0 \\
0\end{array}$ & & \\
\hline $\begin{array}{l}\text { Crown } 2 . \\
\mathrm{N} \text { Portland }\end{array}$ & $\begin{array}{l}1303 \\
1304 \\
1305 \\
1306 \\
1307 \\
1308\end{array}$ & $\begin{array}{l}517003 \\
517008 \\
516907 \\
516821 \\
516828 \\
516733\end{array}$ & $\begin{array}{l}5051801 \\
5051693 \\
5051741 \\
5051792 \\
5051700 \\
5051747\end{array}$ & $\begin{array}{r}31 \\
32 \\
32 \\
32 \\
31.5 \\
33\end{array}$ & $\begin{array}{r}32 \\
31 \\
110 \\
33 \\
34.5 \\
84\end{array}$ & $\begin{array}{r}-1 \\
1 \\
-78 \\
-1 \\
-3 \\
-51\end{array}$ & $\begin{array}{l}0 \\
0 \\
0 \\
0 \\
0 \\
0\end{array}$ & $\begin{array}{l}0.0 \\
0.0 \\
0.0 \\
0.0 \\
0.0 \\
0.0\end{array}$ & $\begin{array}{l}0 \\
0 \\
0 \\
0 \\
0 \\
0\end{array}$ & & $\begin{array}{r}32 \\
31 \\
110 \\
33 \\
34.5 \\
84\end{array}$ & $\begin{array}{r}9.8 \\
9.4 \\
33.5 \\
10.9 \\
10.5 \\
25.6\end{array}$ & $\begin{array}{l}0 \\
0 \\
0 \\
0 \\
0 \\
0\end{array}$ & $\begin{array}{l}0 \\
4 \\
4 \\
4 \\
5 \\
6\end{array}$ & $\begin{array}{r}8 * \\
10 * \\
35 * \\
9 * \\
12 * \\
39 *\end{array}$ \\
\hline Carnation co & $\begin{array}{l}1309 \\
1310 \\
1311 \\
1312 \\
1313 \\
1314 \\
1315 \\
1316 \\
1317 \\
1318 \\
1319 \\
1320\end{array}$ & $\begin{array}{l}518299 \\
518363 \\
518331 \\
518327 \\
518344 \\
518384 \\
518435 \\
518386 \\
518414 \\
518395 \\
518307 \\
518274\end{array}$ & $\begin{array}{l}5053887 \\
5053835 \\
5053821 \\
5053728 \\
5053873 \\
5053871 \\
5053754 \\
5053746 \\
5053822 \\
5553794 \\
5053849 \\
5053923\end{array}$ & $\begin{array}{l}29.4 \\
28.2 \\
29.2 \\
30.5 \\
28.5 \\
29.5 \\
27.0 \\
29.5 \\
29.0 \\
27.8 \\
29.0 \\
29.0\end{array}$ & $\begin{array}{l}151.0 \\
141.5 \\
111.5 \\
106.5 \\
174.0 \\
194.0 \\
124.0 \\
115.5 \\
125.0 \\
114.5 \\
115.5 \\
114.3\end{array}$ & $\begin{array}{r}-121.6 \\
-113.3 \\
-82.3 \\
-76.0 \\
-145.5 \\
-164.5 \\
-97.0 \\
-86.0 \\
-96.0 \\
-86.7 \\
-86.5 \\
-85.3\end{array}$ & $\begin{array}{l}0.0 \\
0.0 \\
0.0 \\
0.0 \\
0.0 \\
0.0 \\
0.0 \\
0.0 \\
0.0 \\
0.0 \\
0.0 \\
0.0\end{array}$ & $\begin{array}{l}0.0 \\
0.0 \\
0.0 \\
0.0 \\
0.0 \\
0.0 \\
0.0 \\
0.0 \\
0.0 \\
0.0 \\
0.0 \\
0.0\end{array}$ & $\begin{array}{l}0 \\
0 \\
0 \\
0 \\
0 \\
0 \\
0 \\
0 \\
0 \\
0 \\
0 \\
0\end{array}$ & & $\begin{array}{l}151.0 \\
141.5 \\
111.5 \\
106.5 \\
174.0 \\
194.0 \\
124.0 \\
115.5 \\
125.0 \\
114.5 \\
115.5 \\
114.3\end{array}$ & $\begin{array}{l}46.0 \\
43.1 \\
34.0 \\
32.5 \\
53.0 \\
59.1 \\
37.8 \\
35.2 \\
38.1 \\
34.9 \\
35.2 \\
34.8\end{array}$ & $\begin{array}{l}1 \\
0 \\
0 \\
0 \\
0 \\
0 \\
0 \\
0 \\
0 \\
0 \\
0 \\
0\end{array}$ & & \\
\hline USACE & 1321 & 521484 & 5053911 & -30.0 & 61.5 & -91.5 & 0.0 & 0.0 & 0 & & 61.5 & 18.7 & 0 & 2 & 86 \\
\hline PP\&L lone Reef & $\begin{array}{l}1322 \\
1323\end{array}$ & $\begin{array}{l}546149 \\
546097\end{array}$ & $\begin{array}{l}5046081 \\
5046063\end{array}$ & $\begin{array}{l}5.7 \\
7.7\end{array}$ & $\begin{array}{l}30.7 \\
32.2\end{array}$ & $\begin{array}{l}-25.0 \\
-24.5\end{array}$ & $\begin{array}{l}5.7 \\
7.7\end{array}$ & $\begin{array}{l}1.7 \\
2.3\end{array}$ & 1 & $\begin{array}{l}\text { Bslt } \\
\text { Bslt }\end{array}$ & $\begin{array}{l}0.0 \\
0.0\end{array}$ & $\begin{array}{l}0.0 \\
0.0\end{array}$ & $\begin{array}{l}0 \\
0\end{array}$ & & \\
\hline $\begin{array}{l}\text { DOGAMI DATA } \\
162 \text { nd } \times \text { Sandy } \\
\text { 162nd X Airporthy } \\
\text { Marine } \times \text { 158th } \\
\text { 158th X Columbia slu } \\
\text { Hemlock }\end{array}$ & $\begin{array}{l}1324 \\
1325 \\
1326 \\
1327 \\
1328\end{array}$ & $\begin{array}{l}539430 \\
539460 \\
539100 \\
539120 \\
539730\end{array}$ & $\begin{array}{l}5044065 \\
5044960 \\
5045230 \\
5044260 \\
5044710\end{array}$ & $\begin{array}{l}30 \\
20 \\
20 \\
17 \\
15\end{array}$ & $\begin{array}{r}680 \\
28 \\
490 \\
320 \\
22\end{array}$ & $\begin{array}{r}-650 \\
-8 \\
-470 \\
-303 \\
-7\end{array}$ & $\begin{array}{r}18 \\
2 \\
-36 \\
4 \\
-1\end{array}$ & $\begin{array}{r}5.5 \\
0.6 \\
-11.0 \\
1.2 \\
-0.3\end{array}$ & $\begin{array}{l}1 \\
1 \\
1 \\
1 \\
1\end{array}$ & $\begin{array}{r}\text { Qlg? } \\
\text { Tt? Qlg? } \\
\text { Tt Qlg? } \\
\text { Qlg? Tt? } \\
\text { Qlg? Tt? }\end{array}$ & $\begin{array}{l}12 \\
18 \\
56 \\
13 \\
16\end{array}$ & $\begin{array}{r}3.7 \\
5.5 \\
17.1 \\
4.0 \\
4.9\end{array}$ & $\begin{array}{l}0 \\
0 \\
0 \\
0 \\
0\end{array}$ & $\begin{array}{l}1 \\
1\end{array}$ & $\begin{array}{l}11 \\
15\end{array}$ \\
\hline $\begin{array}{l}\text { PIA } \\
\text { PIA } \\
\text { PIA } \\
\text { PIA }\end{array}$ & $\begin{array}{l}1329 \\
1330 \\
1331 \\
1332\end{array}$ & $\begin{array}{l}531490 \\
533000 \\
534130 \\
530240\end{array}$ & $\begin{array}{l}5049020 \\
5047785 \\
5047120 \\
5047780\end{array}$ & $\begin{array}{l}24 \\
15 \\
20 \\
14\end{array}$ & $\begin{array}{l}84 \\
80 \\
70 \\
59\end{array}$ & $\begin{array}{l}-60 \\
-65 \\
-50 \\
-45\end{array}$ & $\begin{array}{l}0 \\
0 \\
0 \\
0\end{array}$ & $\begin{array}{l}0.0 \\
0.0 \\
0.0 \\
0.0\end{array}$ & $\begin{array}{l}0 \\
0 \\
0 \\
0\end{array}$ & & $\begin{array}{l}84 \\
80 \\
70 \\
59\end{array}$ & $\begin{array}{l}25.6 \\
24.4 \\
21.3 \\
18.0\end{array}$ & $\begin{array}{l}0 \\
0 \\
0 \\
0\end{array}$ & $\begin{array}{l}4 \\
0 \\
2\end{array}$ & $\begin{array}{l}29 \\
48 \\
40\end{array}$ \\
\hline
\end{tabular}


Elev Ft Depth Ft Base Ft Contactft ContactM Code Lithol Feet Meters Code Min Max

\begin{tabular}{|c|c|c|c|}
\hline 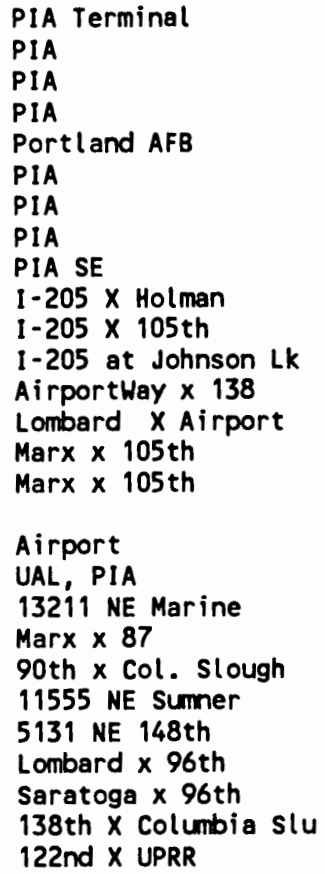 & $\begin{array}{l}1333 \\
1334 \\
1335 \\
1336 \\
1337 \\
1338 \\
1339 \\
1340 \\
1341 \\
1342 \\
1343 \\
1344 \\
1345 \\
1346 \\
1347 \\
1348 \\
1349 \\
1350 \\
1351 \\
1352 \\
1353 \\
1354 \\
1355 \\
1356 \\
1357 \\
1358 \\
1359 \\
1360\end{array}$ & $\begin{array}{l}531810 \\
530560 \\
532170 \\
533000 \\
531150 \\
533300 \\
532880 \\
532020 \\
533890 \\
534900 \\
534860 \\
534500 \\
537480 \\
533950 \\
534860 \\
535370 \\
535820 \\
531545 \\
533330 \\
537340 \\
533330 \\
533580 \\
535690 \\
538350 \\
534100 \\
534100 \\
537390 \\
536260\end{array}$ & $\begin{array}{l}5048290 \\
5049130 \\
5048070 \\
5047530 \\
5047220 \\
5047460 \\
5046790 \\
5048170 \\
5046090 \\
5045955 \\
5045830 \\
5045520 \\
5045350 \\
5046260 \\
5045350 \\
5045195 \\
5045990 \\
5048500 \\
5047580 \\
5045650 \\
5045800 \\
5045950 \\
5045250 \\
5044500 \\
5046850 \\
5046300 \\
5045130 \\
5044850\end{array}$ \\
\hline $\begin{array}{l}82 \text { nd } \times \text { Columbia Slu } \\
\text { Whitaker } \times 138 \text { th } \\
\text { PIA Mil itary } \\
\text { Sandy } \times 142 \\
\text { PIA } \\
\text { Invernees Dr. } \\
\text { Ainsworth CircxAirpt } \\
4200 \text { Columbia Way } \\
\text { Doane lake } \\
\text { I-5 } \times \text { Columbia sloug } \\
\text { Yeon } \times 26 \text { th } \\
\text { Elrod } \times 21 \text { st. }\end{array}$ & $\begin{array}{l}1361 \\
1362 \\
1363 \\
1364 \\
1365 \\
1366 \\
1367 \\
1368 \\
1369 \\
1370 \\
1371 \\
1372\end{array}$ & $\begin{array}{l}533100 \\
537200 \\
531900 \\
537920 \\
532520 \\
535900 \\
535770 \\
529700 \\
519580 \\
524970 \\
522940 \\
527820\end{array}$ & $\begin{array}{l}5045930 \\
5045020 \\
5047100 \\
5044480 \\
5047790 \\
5045440 \\
5045830 \\
5051350 \\
5045870 \\
5048160 \\
5043460 \\
5047540\end{array}$ \\
\hline
\end{tabular}

\begin{tabular}{|c|c|c|c|c|c|c|c|c|c|c|}
\hline $\begin{array}{l}17 \\
20 \\
22 \\
17 \\
10 \\
40 \\
18 \\
20 \\
24 \\
18 \\
22 \\
16 \\
15 \\
20 \\
18 \\
28 \\
20 \\
20 \\
20 \\
20 \\
20 \\
15 \\
15 \\
25 \\
25 \\
7 \\
20 \\
28\end{array}$ & $\begin{array}{r}117 \\
75 \\
117 \\
80 \\
95 \\
90 \\
39 \\
126 \\
47 \\
60 \\
50 \\
25 \\
28 \\
80 \\
20 \\
13 \\
60 \\
216 \\
110 \\
122 \\
10 \\
125 \\
418 \\
280 \\
355 \\
399 \\
365 \\
50\end{array}$ & $\begin{array}{r}-100 \\
-55 \\
-95 \\
-63 \\
-85 \\
-50 \\
-21 \\
-106 \\
-30 \\
-60 \\
-50 \\
-25 \\
-13 \\
-60 \\
-20 \\
15 \\
-40 \\
-196 \\
-90 \\
-102 \\
10 \\
-110 \\
-403 \\
-255 \\
-320 \\
-392 \\
-345 \\
-22\end{array}$ & $\begin{array}{r}0 \\
0 \\
0 \\
0 \\
0 \\
0 \\
0 \\
-102 \\
-23 \\
-42 \\
-13 \\
10 \\
-5 \\
0 \\
6 \\
23 \\
0 \\
0 \\
0 \\
-100 \\
10 \\
-103 \\
4 \\
-9 \\
-175 \\
-167 \\
-14 \\
24\end{array}$ & $\begin{array}{r}0.0 \\
0.0 \\
0.0 \\
0.0 \\
0.0 \\
0.0 \\
0.0 \\
-31.1 \\
-7.0 \\
-12.8 \\
-4.0 \\
3.0 \\
-1.5 \\
0.0 \\
1.8 \\
7.0 \\
0.0 \\
0.0 \\
0.0 \\
-30.5 \\
3.0 \\
-31.4 \\
1.2 \\
-2.7 \\
-53.3 \\
-50.9 \\
-4.3 \\
7.3\end{array}$ & $\begin{array}{l}0 \\
0 \\
0 \\
0 \\
0 \\
0 \\
0 \\
1 \\
1 \\
1 \\
1 \\
1 \\
1 \\
0 \\
1 \\
1 \\
0 \\
0 \\
0 \\
1 \\
1 \\
1 \\
1 \\
1 \\
1 \\
1 \\
1 \\
1\end{array}$ & $\begin{array}{r} \\
\text { Qal? Tt? } \\
\text { Tt? Qlg? } \\
\text { Qlg } \\
\text { Qlg } \\
\text { Qlg } \\
\text { Qlg? Tt? } \\
\text { Tt? Qls/g } \\
\text { Tt Qlg? } \\
\text { Qlg }\end{array}$ & $\begin{array}{r}117 \\
75 \\
117 \\
80 \\
95 \\
90 \\
39 \\
122 \\
47 \\
60 \\
35 \\
6 \\
20 \\
80 \\
12 \\
5 \\
60 \\
216 \\
110 \\
120 \\
10 \\
118 \\
9 \\
34 \\
175 \\
174 \\
34 \\
4\end{array}$ & $\begin{array}{r}35.7 \\
22.9 \\
35.7 \\
24.4 \\
29.0 \\
27.4 \\
11.9 \\
37.2 \\
14.3 \\
18.3 \\
10.7 \\
1.8 \\
6.1 \\
24.4 \\
3.7 \\
1.5 \\
18.3 \\
65.8 \\
33.5 \\
36.6 \\
3.0 \\
36.0 \\
2.7 \\
10.4 \\
53.3 \\
53.0 \\
10.4 \\
1.2\end{array}$ & $\begin{array}{l}0 \\
0 \\
0 \\
0 \\
0 \\
0 \\
0 \\
0 \\
0 \\
0 \\
0 \\
0 \\
0 \\
0 \\
0 \\
0 \\
0 \\
0 \\
0 \\
0 \\
0 \\
0 \\
0 \\
0 \\
0 \\
0 \\
0 \\
0\end{array}$ & $\begin{array}{r}1 \\
14 \\
3 \\
2 \\
2 \\
2 \\
2 \\
4 \\
3 \\
1 \\
4 \\
9\end{array}$ \\
\hline $\begin{array}{l}25 \\
15 \\
20 \\
35 \\
20 \\
22 \\
25 \\
35 \\
50 \\
10 \\
35 \\
20\end{array}$ & $\begin{array}{r}61 \\
15 \\
54 \\
23 \\
51 \\
33 \\
51 \\
260 \\
60 \\
80 \\
140 \\
70\end{array}$ & $\begin{array}{r}-38 \\
-15 \\
-34 \\
12 \\
-31 \\
-11 \\
-26 \\
-225 \\
-10 \\
-70 \\
-105 \\
-50\end{array}$ & $\begin{array}{r}-35 \\
5 \\
0 \\
31 \\
0 \\
-10 \\
-25 \\
34 \\
0 \\
-35 \\
-100 \\
-40\end{array}$ & $\begin{array}{r}-10.7 \\
1.5 \\
0.0 \\
9.4 \\
0.0 \\
-3.0 \\
-7.6 \\
10.4 \\
0.0 \\
-10.7 \\
-30.5 \\
-12.2\end{array}$ & $\begin{array}{l}1 \\
1 \\
0 \\
1 \\
0 \\
1 \\
1 \\
1 \\
0 \\
1 \\
1 \\
1\end{array}$ & $\begin{array}{r}\text { Qlg? Tt } \\
\text { Qlg Tt? } \\
\text { Qlg } \\
\text { Qlg? Tt? } \\
\text { olg Tt? } \\
\text { Omc? } \\
\text { Tt? Qlg? } \\
T t \\
\text { Tt? }\end{array}$ & $\begin{array}{r}60 \\
10 \\
54 \\
4 \\
51 \\
32 \\
50 \\
1 \\
60 \\
45 \\
135 \\
60\end{array}$ & $\begin{array}{r}18.3 \\
3.0 \\
16.5 \\
1.2 \\
15.5 \\
9.8 \\
15.2 \\
0.3 \\
18.3 \\
13.7 \\
41.1 \\
18.3\end{array}$ & $\begin{array}{l}0 \\
0 \\
0 \\
0 \\
0 \\
0 \\
0 \\
0 \\
0 \\
0 \\
0 \\
0\end{array}$ & $\begin{array}{l}1 \\
8 \\
3\end{array}$ \\
\hline
\end{tabular}


Elev Ft Depth Ft Base Ft Contactft ContactM Code Lithol Feet Meters Code Min Max

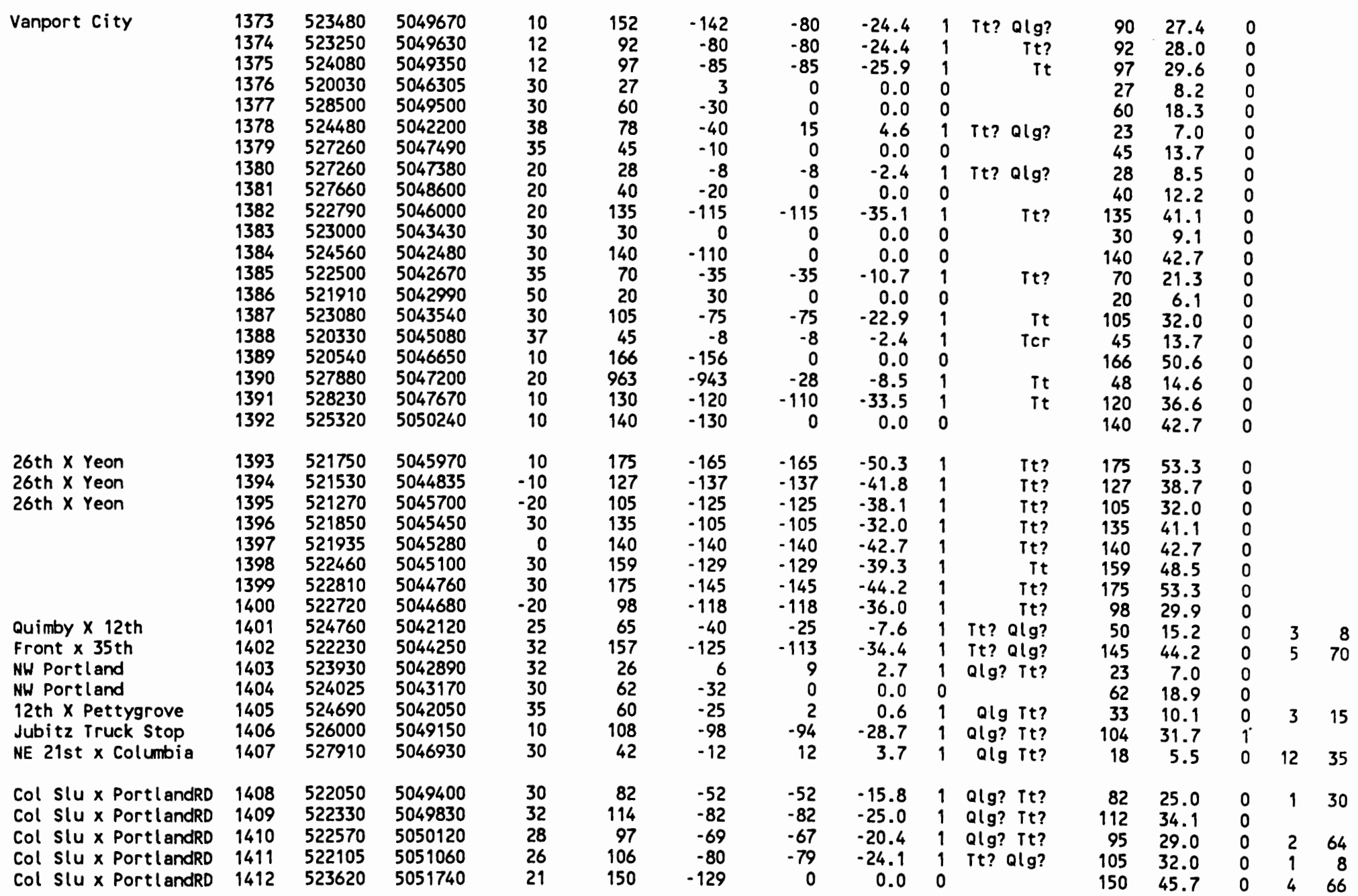




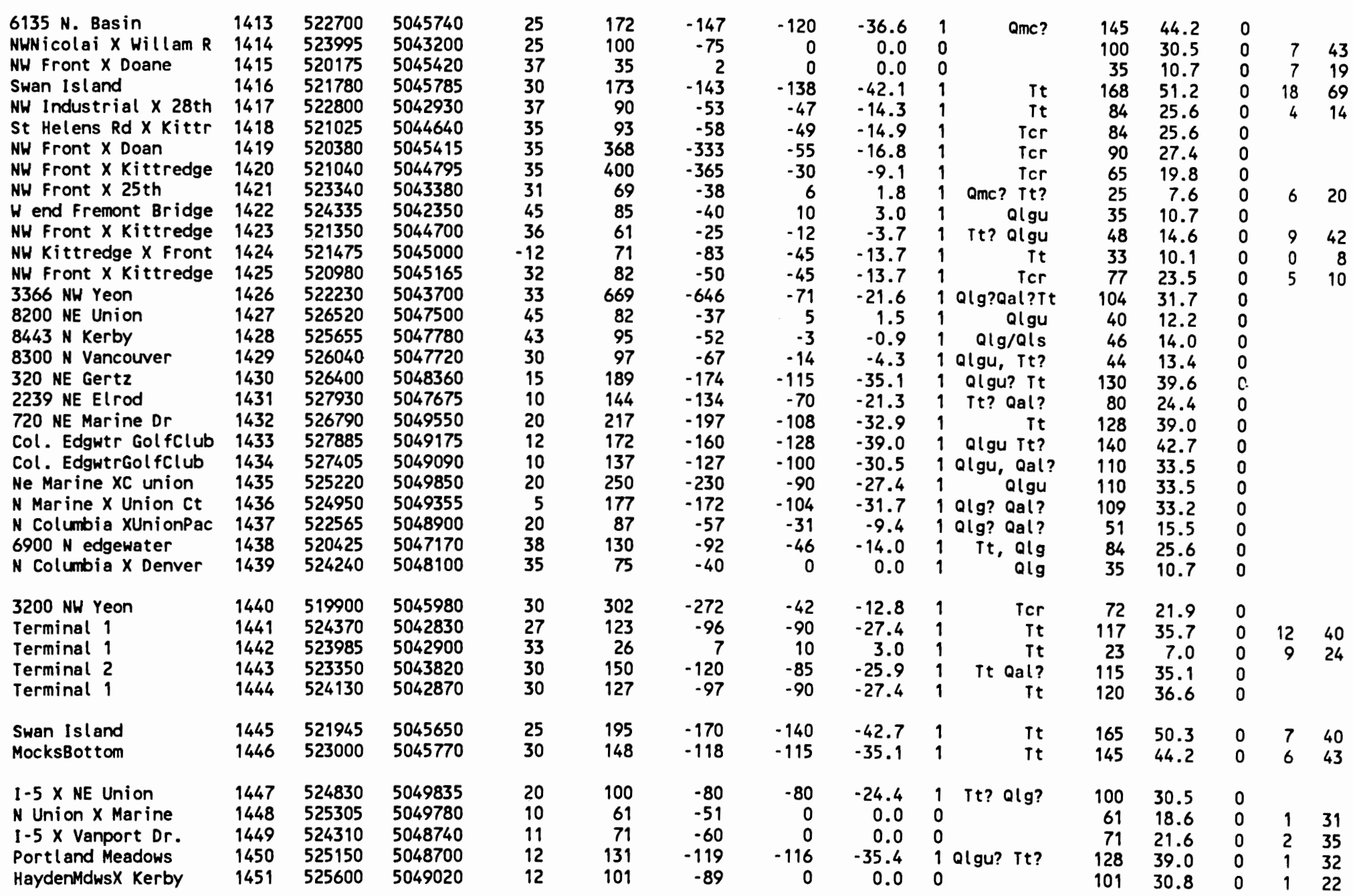


Hole Hole QalBasal QalBasal GIS Basal Isopach Isopach Ash SPT

\begin{tabular}{|c|c|c|c|c|c|c|c|c|c|c|c|c|c|c|c|}
\hline $\begin{array}{l}\text { Del ta Park Fairgrnds } \\
2300 \mathrm{~N} \text { Columbia } \\
\text { NEVancouverXSchmeer } \\
\text { NE Gertz X } 13 \text { th } \\
\text { NE Columbia Ct }\end{array}$ & $\begin{array}{l}1452 \\
1453 \\
1454 \\
1455 \\
1456\end{array}$ & $\begin{array}{l}525250 \\
524190 \\
526130 \\
527100 \\
526640\end{array}$ & $\begin{array}{l}5048900 \\
5048220 \\
5047940 \\
5048290 \\
5047780\end{array}$ & $\begin{array}{r}10 \\
35 \\
20 \\
6 \\
20\end{array}$ & $\begin{array}{r}132 \\
35 \\
52 \\
56 \\
15\end{array}$ & $\begin{array}{r}-122 \\
0 \\
-32 \\
-50 \\
5\end{array}$ & $\begin{array}{r}-120 \\
6 \\
0 \\
0 \\
7\end{array}$ & $\begin{array}{r}-36.6 \\
1.8 \\
0.0 \\
0.0 \\
2.1\end{array}$ & $\begin{array}{l}1 \\
1 \\
0 \\
0 \\
1\end{array}$ & Qlgu Tt? & $\begin{array}{r}130 \\
29 \\
52 \\
56 \\
13\end{array}$ & $\begin{array}{r}39.6 \\
8.8 \\
15.8 \\
17.1 \\
4.0\end{array}$ & $\begin{array}{l}0 \\
0 \\
0 \\
0 \\
0\end{array}$ & $\begin{array}{l}3 \\
2 \\
1 \\
9\end{array}$ & $\begin{array}{l}18 \\
30 \\
42 \\
25\end{array}$ \\
\hline $\begin{array}{l}\text { Mocks Bottom } \\
\text { Mocks Bottom }\end{array}$ & $\begin{array}{l}1457 \\
1458\end{array}$ & $\begin{array}{l}522345 \\
523090\end{array}$ & $\begin{array}{l}5045870 \\
5046440\end{array}$ & $\begin{array}{r}1 \\
45\end{array}$ & $\begin{array}{r}82 \\
114\end{array}$ & $\begin{array}{l}-81 \\
-69\end{array}$ & $\begin{array}{l}0 \\
0\end{array}$ & $\begin{array}{l}0.0 \\
0.0\end{array}$ & $\begin{array}{l}0 \\
0\end{array}$ & & $\begin{array}{r}82 \\
114\end{array}$ & $\begin{array}{l}25.0 \\
34.7\end{array}$ & $\begin{array}{l}0 \\
0\end{array}$ & $\begin{array}{r}18 \\
2\end{array}$ & $\begin{array}{l}32 \\
38\end{array}$ \\
\hline $\begin{array}{l}\text { East end Smith Lake } \\
N \text { end smith Lake } \\
N \text { Columbia X Portlan } \\
\text { Going St Harehouse } \\
\text { 26th X Yeon } \\
\text { Foot of Nicolai } \\
\text { St. Helensx } 31 \text { st } \\
\text { Frmnt Br X Front } \\
N \text { River X Clark }\end{array}$ & $\begin{array}{l}1459 \\
1460 \\
1461 \\
1462 \\
1463 \\
1464 \\
1465 \\
1466 \\
1467\end{array}$ & $\begin{array}{l}522740 \\
522200 \\
521980 \\
525055 \\
522995 \\
523945 \\
522375 \\
524820 \\
525200\end{array}$ & $\begin{array}{l}5050400 \\
5051260 \\
5049140 \\
5043210 \\
5043500 \\
5043180 \\
5042730 \\
5042270 \\
5042650\end{array}$ & $\begin{array}{l}25 \\
13 \\
32 \\
35 \\
35 \\
30 \\
30 \\
32 \\
30\end{array}$ & $\begin{array}{r}100 \\
88 \\
57 \\
50 \\
145 \\
105 \\
90 \\
84 \\
50\end{array}$ & $\begin{array}{l}-75 \\
-75 \\
-25 \\
-15 \\
-110 \\
-75 \\
-60 \\
-52 \\
-20\end{array}$ & $\begin{array}{r}-70 \\
-70 \\
-4 \\
0 \\
-105 \\
0 \\
-60 \\
0 \\
-7\end{array}$ & $\begin{array}{r}-21.3 \\
-21.3 \\
-1.2 \\
0.0 \\
-32.0 \\
0.0 \\
-18.3 \\
0.0 \\
-2.1\end{array}$ & $\begin{array}{l}1 \\
1 \\
1 \\
0 \\
1 \\
0 \\
1 \\
0 \\
1\end{array}$ & $\begin{array}{r}\text { Tt } Q \text { Qlg? } \\
\text { Tt? Qlg? } \\
\text { Tt olgu? } \\
\text { Tt } \\
\text { Tt } \\
\text { Tt Qlg? }\end{array}$ & $\begin{array}{r}95 \\
83 \\
36 \\
50 \\
140 \\
105 \\
90 \\
84 \\
37\end{array}$ & $\begin{array}{l}29.0 \\
25.3 \\
11.0 \\
15.2 \\
42.7 \\
32.0 \\
27.4 \\
25.6 \\
11.3\end{array}$ & $\begin{array}{l}0 \\
0 \\
0 \\
0 \\
0 \\
0 \\
0 \\
0 \\
0\end{array}$ & $\begin{array}{r}2 \\
2 \\
11 \\
3 \\
0 \\
6 \\
5\end{array}$ & $\begin{array}{l}30 \\
50 \\
56 \\
70\end{array}$ \\
\hline $\begin{array}{l}\text { NW 35th } \times \text { Luzon } \\
\text { Industrial } \times 26 \text { th } \\
26 \text { th } \times \text { Front } \\
\text { Luzon } \times 31 \text { st } \\
\text { 20th } \times \text { Wilson } \\
31 \text { st } \times \text { Yeon } \\
30 \times \text { St. Johns Bridge } \\
N \text { ColumbiaxLombard }\end{array}$ & $\begin{array}{l}1468 \\
1469 \\
1470 \\
1471 \\
1472 \\
1473 \\
1474 \\
1475\end{array}$ & $\begin{array}{l}522050 \\
523040 \\
523090 \\
522300 \\
524100 \\
522560 \\
519050 \\
518560\end{array}$ & $\begin{array}{l}5043060 \\
5043000 \\
5043660 \\
5043150 \\
5042580 \\
5043460 \\
5046940 \\
5051180\end{array}$ & $\begin{array}{l}32 \\
30 \\
30 \\
37 \\
36 \\
34 \\
26 \\
16\end{array}$ & $\begin{array}{r}102 \\
85 \\
125 \\
105 \\
31 \\
149 \\
400 \\
99\end{array}$ & $\begin{array}{r}-70 \\
-55 \\
-95 \\
-68 \\
5 \\
-115 \\
-374 \\
-83\end{array}$ & $\begin{array}{r}0 \\
-45 \\
-90 \\
-10 \\
12 \\
-10 \\
-24 \\
0\end{array}$ & $\begin{array}{r}0.0 \\
-13.7 \\
-27.4 \\
-3.0 \\
3.7 \\
-3.0 \\
-7.3 \\
0.0\end{array}$ & $\begin{array}{l}0 \\
1 \\
1 \\
1 \\
1 \\
1 \\
1 \\
0\end{array}$ & $\begin{array}{r}T t ? \text { Qal? } \\
T t \\
T t ? \\
\text { Qlg Tt } \\
T t ? \text { Qlg } \\
T c r\end{array}$ & $\begin{array}{r}102 \\
75 \\
120 \\
47 \\
24 \\
44 \\
50 \\
99\end{array}$ & $\begin{array}{r}31.1 \\
22.9 \\
36.6 \\
14.3 \\
7.3 \\
13.4 \\
15.2 \\
30.2\end{array}$ & $\begin{array}{l}0 \\
0 \\
0 \\
0 \\
0 \\
0 \\
0 \\
0\end{array}$ & $\begin{array}{l}3 \\
3 \\
6\end{array}$ & $\begin{array}{l}34 \\
20\end{array}$ \\
\hline $\begin{array}{l}\text { LinntonplywoodPlant } \\
\text { Mobil Oil } \\
\text { Terminal } 4 \\
\text { Terminal } 4 \text { Slip } 1 \\
\text { Termninal } 4 \\
\text { N ramsey } X \text { Rivergate } \\
\text { Rivergate } \\
\text { Rivergate } \\
\text { Terminal } 4 \\
\text { International Term. } \\
W \text { end St Johns Brdge } \\
W \text { tower, St. JohnsBr }\end{array}$ & $\begin{array}{l}1476 \\
1477 \\
1478 \\
1479 \\
1480 \\
1481 \\
1482 \\
1483 \\
1484 \\
1485 \\
1486 \\
1487\end{array}$ & $\begin{array}{l}517095 \\
517400 \\
517660 \\
517560 \\
517680 \\
516700 \\
516740 \\
518005 \\
517800 \\
518060 \\
518150 \\
518375\end{array}$ & $\begin{array}{l}5049100 \\
5048640 \\
5050130 \\
5049870 \\
5049190 \\
5051930 \\
5052140 \\
5051600 \\
5048980 \\
5050380 \\
5047790 \\
5047670\end{array}$ & $\begin{array}{r}40 \\
30 \\
30 \\
-20 \\
-30 \\
10 \\
32 \\
30 \\
-20 \\
28 \\
30 \\
-9\end{array}$ & $\begin{array}{r}80 \\
65 \\
205 \\
127 \\
145 \\
115 \\
187 \\
205 \\
150 \\
68 \\
61 \\
19\end{array}$ & $\begin{array}{l}-40 \\
-35 \\
-175 \\
-147 \\
-175 \\
-105 \\
-155 \\
-175 \\
-170 \\
-40 \\
-31 \\
-28\end{array}$ & $\begin{array}{r}-10 \\
-35 \\
-160 \\
-147 \\
-155 \\
0 \\
-153 \\
-170 \\
-165 \\
-40 \\
-30 \\
-14\end{array}$ & $\begin{array}{r}-3.0 \\
-10.7 \\
-48.8 \\
-44.8 \\
-47.2 \\
0.0 \\
-46.6 \\
-51.8 \\
-50.3 \\
-12.2 \\
-9.1 \\
-4.3\end{array}$ & $\begin{array}{l}1 \\
1 \\
1 \\
1 \\
1 \\
0 \\
1 \\
1 \\
1 \\
1 \\
1 \\
1\end{array}$ & $\begin{array}{r}\text { Tcr } \\
\text { Tcr } \\
T t ? \\
T t \\
T t ? \text { Qal? } \\
\\
T t \\
T t \\
T t \\
T t \\
\text { Qfc? Tt? } \\
T c r \\
T c r\end{array}$ & $\begin{array}{r}50 \\
65 \\
-190 \\
127 \\
125 \\
115 \\
185 \\
200 \\
145 \\
68 \\
38 \\
5\end{array}$ & $\begin{array}{l}15.2 \\
19.8 \\
57.9 \\
38.7 \\
38.1 \\
35.1 \\
56.4 \\
61.0 \\
44.2 \\
20.7 \\
11.6 \\
1.5\end{array}$ & $\begin{array}{l}0 \\
0 \\
0 \\
0 \\
0 \\
0 \\
0 \\
0 \\
0 \\
0 \\
0 \\
0\end{array}$ & $\begin{array}{l}7 \\
2 \\
15 \\
13\end{array}$ & $\begin{array}{l}41 \\
42 \\
38 \\
48 \\
\\
32 \\
41 \\
78\end{array}$ \\
\hline
\end{tabular}




\section{APPENDIX C}

MAZAMA ASH DATA 
APPENDIX C MAZAMA ASH OCCURRENCE DATA

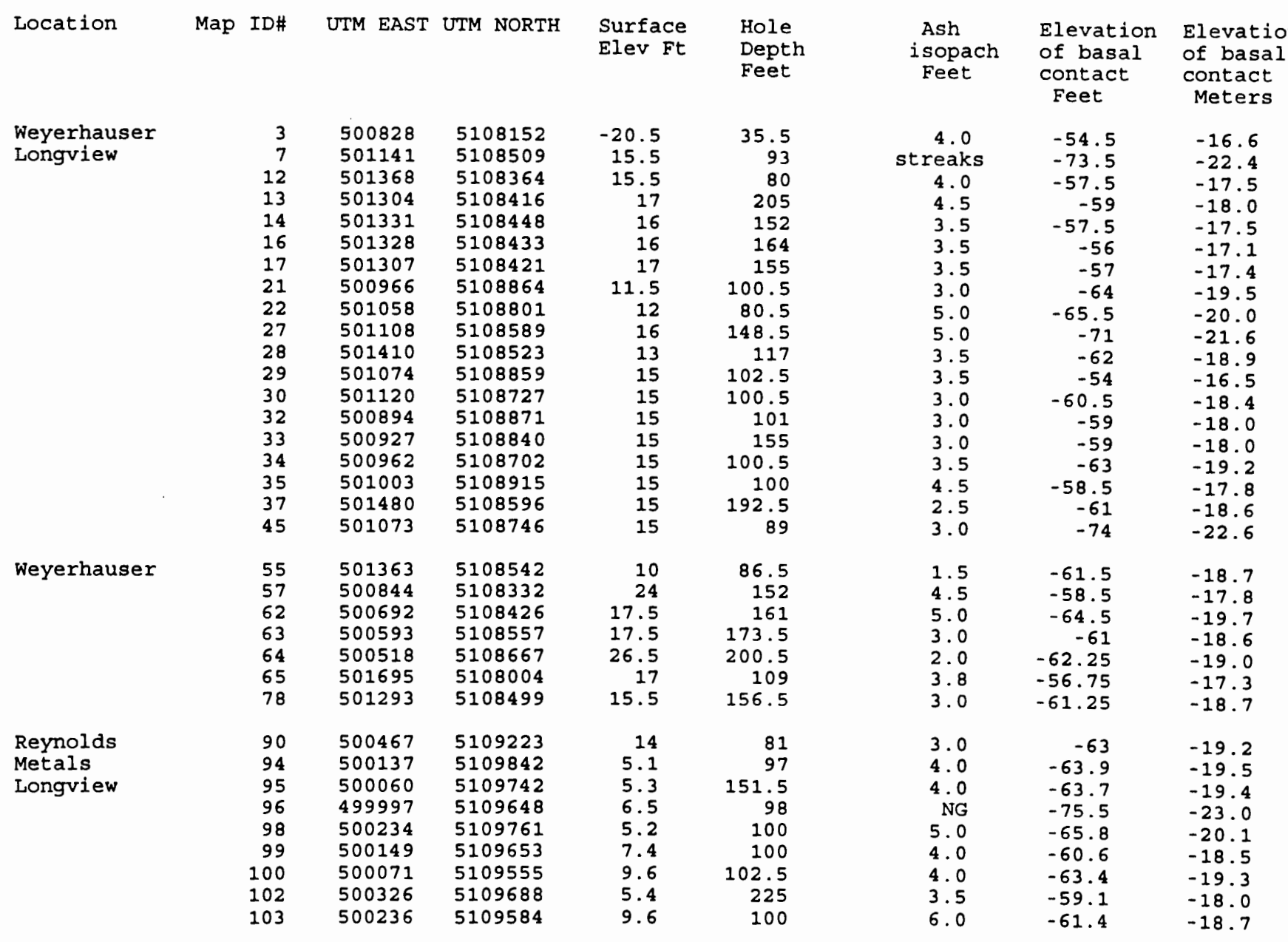




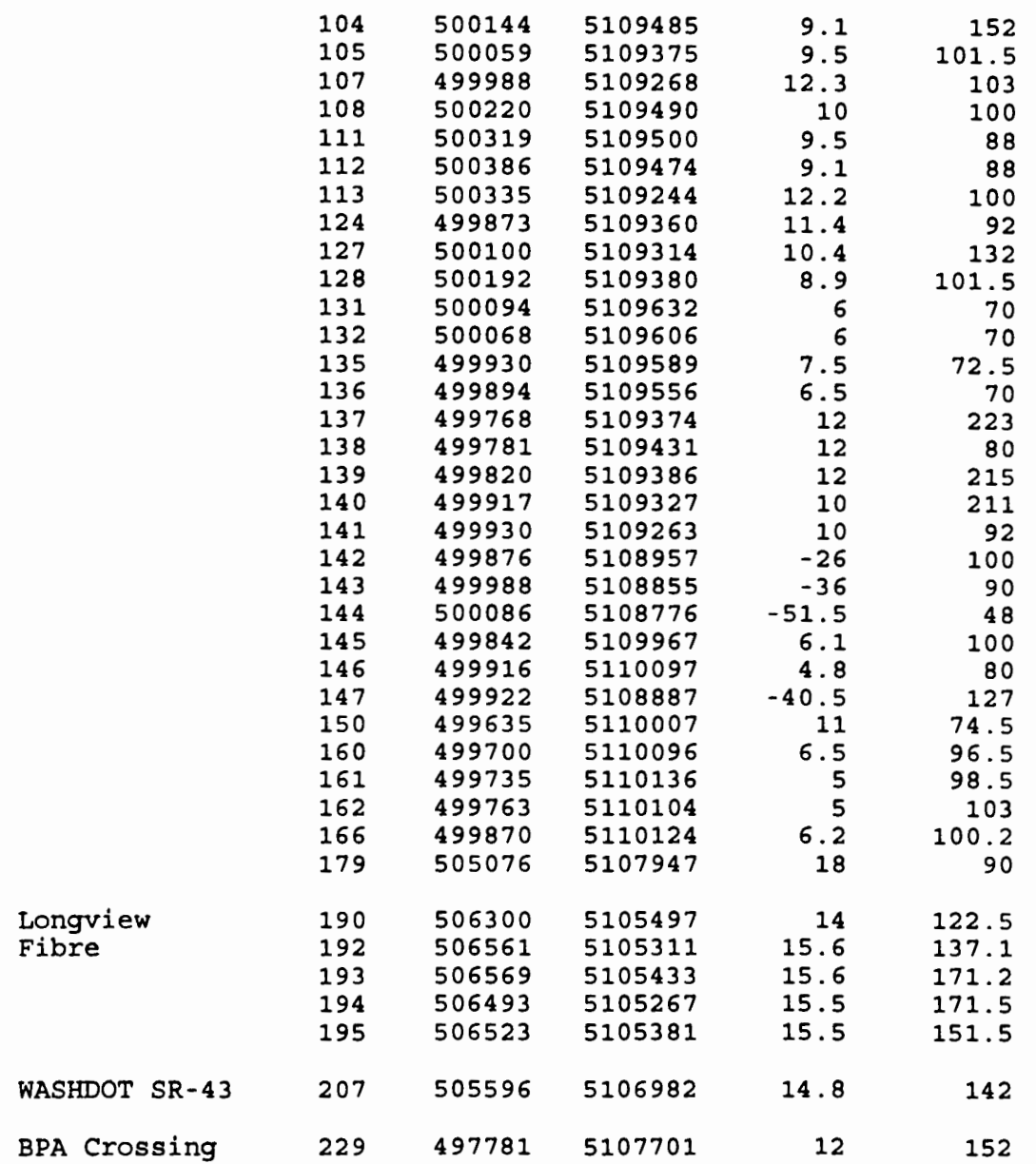

\begin{tabular}{|c|c|c|}
\hline $\begin{array}{c}3.0 \\
4.0 \\
3.0 \\
9.0 \\
11.5 \\
12.5 \\
2.0 \\
2.0 \\
4.0 \\
5.5 \\
3.5 \\
4.0 \\
4.0 \\
3.0 \\
3.5 \\
3.5 \\
3.0 \\
4.5 \\
3.0 \\
5.0 \\
2.0 \\
5.0 \\
6.0 \\
\text { streaks } \\
4.5 \\
1.0 \\
3.0 \\
3.0 \\
5.5 \\
5.0 \\
2.5\end{array}$ & $\begin{array}{r}-65.1 \\
-61 \\
-42.7 \\
-66.5 \\
-69.5 \\
-75.9 \\
-59.8 \\
-62.6 \\
-64.1 \\
-65.1 \\
-59 \\
-61 \\
-63 \\
-58.5 \\
-65 \\
-65 \\
-64.5 \\
-64 \\
-59.5 \\
-62 \\
-62 \\
-74 \\
-64.9 \\
-66.2 \\
-61.5 \\
-62.5 \\
-86.5 \\
-87.5 \\
-88 \\
-63 \\
-63.5\end{array}$ & $\begin{array}{l}-19.8 \\
-18.6 \\
-13.0 \\
-20.3 \\
-21.2 \\
-23.1 \\
-18.2 \\
-19.1 \\
-19.5 \\
-19.8 \\
-18.0 \\
-18.6 \\
-19.2 \\
-17.8 \\
-19.8 \\
-19.8 \\
-19.7 \\
-19.5 \\
-18.1 \\
-18.9 \\
-18.9 \\
-22.6 \\
-19.8 \\
-20.2 \\
-18.7 \\
-19.1 \\
-26.4 \\
-26.7 \\
-26.8 \\
-19.2 \\
-19.4\end{array}$ \\
\hline $\begin{array}{l}2.5 \\
8.5 \\
5.0 \\
3.5 \\
5.0\end{array}$ & $\begin{array}{r}-56 \\
-60.8 \\
-61.1 \\
-59 \\
-59.5\end{array}$ & $\begin{array}{l}-17.1 \\
-18.5 \\
-18.6 \\
-18.0 \\
-18.1\end{array}$ \\
\hline 1.0 & -60.2 & -18.3 \\
\hline 1.5 & -56.5 & -17.2 \\
\hline
\end{tabular}


Location

\begin{tabular}{|c|c|c|c|}
\hline CERRO COrP & $\begin{array}{l}235 \\
236 \\
237\end{array}$ & $\begin{array}{l}497937 \\
497640 \\
497174\end{array}$ & $\begin{array}{l}5111132 \\
5111014 \\
5120817\end{array}$ \\
\hline $\begin{array}{l}\text { Proposed Grain } \\
\text { Storage Facility } \\
\text { Longview }\end{array}$ & $\begin{array}{l}238 \\
239 \\
240 \\
241 \\
242 \\
243 \\
244 \\
245\end{array}$ & $\begin{array}{l}498639 \\
498514 \\
498551 \\
498772 \\
498807 \\
498618 \\
498418 \\
498448\end{array}$ & $\begin{array}{l}5109682 \\
5109658 \\
5109766 \\
5109600 \\
5109701 \\
5109624 \\
5109676 \\
5109788\end{array}$ \\
\hline T8NR3W26 & 251 & 498485 & 5110492 \\
\hline Beaver Plant & $\begin{array}{l}1112 \\
1124 \\
1143 \\
1149 \\
1150 \\
1151 \\
1153\end{array}$ & $\begin{array}{l}486145 \\
486422 \\
486299 \\
486248 \\
486223 \\
486364 \\
486262\end{array}$ & $\begin{array}{l}5113179 \\
5113284 \\
5112972 \\
5113003 \\
5112959 \\
5112966 \\
5112931\end{array}$ \\
\hline $\begin{array}{l}\text { Dames \& Moore } \\
\text { PGE Crossing }\end{array}$ & $\begin{array}{l}1156 \\
1157 \\
1158\end{array}$ & $\begin{array}{l}486450 \\
486461 \\
486455\end{array}$ & $\begin{array}{l}5114026 \\
5114815 \\
5114886\end{array}$ \\
\hline Bradbury slough & 1072 & 486001 & 5112164 \\
\hline \multicolumn{4}{|c|}{ Longview basin averages } \\
\hline Trojan & $\begin{array}{r}209 \\
210 \\
212 \\
214 \\
1280 \\
1290\end{array}$ & $\begin{array}{l}508663 \\
508701 \\
508731 \\
508720 \\
508928 \\
508296\end{array}$ & $\begin{array}{l}5098237 \\
5098307 \\
5097741 \\
5097696 \\
5097060 \\
5097879\end{array}$ \\
\hline
\end{tabular}

Surface
Elev Ft

\section{Hole}

Depth

Ash

isopach

Feet

Elevation

of basal

contact

Feet

levation

Feet

135.5
187

150

$\begin{array}{ll}10.7 & 147.7 \\ 13.2 & 141.2\end{array}$

$\begin{array}{rr}13.2 & 141.2 \\ 5.4 & 76.4\end{array}$

$\begin{array}{rr}5.4 & 76.4 \\ 15.4 & 142.4\end{array}$

$5.4 \quad 101.4$

$14.2 \quad 141.2$

$15.7 \quad 141.7$

142

$20 \quad 200$

13.5

12.5

14.5

11

14
14

14

19.2

21.3

20.8

9

\section{114}

108

105

102

102

76.5
151.5

151.5
101.5

150

7.0
4.0
6.0

1.0

3.0
3.0

3.0
1.0

11.0

17.0

1.5

2.5

NG

3.0
5.0
5.0

3.0

3.0

3.5
3.0

-68
-56

-56
-70

$-74$

-65
-62.5

$-60$

-60
-75
-88

$-60.5$

$-64.5$

-47 *

$-84.5$

$-43.5$

$-60.5$

$-57.5$

$-58.5$

-62
-59

$1.5 \quad-57.3$

TL $\quad-81.7$

$-59.2$

2.0

$-53$

3.82

$-62.87$

$-19.2$

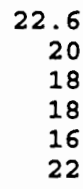

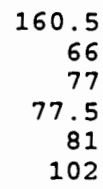

5.0
0.5
$<3.0$
3.5
1.0
4.0

-56
-4
-5
-59.5
-47
-58
$-17.3$

$-18.0$

$-18.0$

$-14.3$

$-17.7$ 


\begin{tabular}{|c|c|c|c|c|c|c|c|c|}
\hline Location & ID\# & UTM EAST & UTM NORTH & $\begin{array}{l}\text { Surface } \\
\text { Elev Ft }\end{array}$ & $\begin{array}{l}\text { Hole } \\
\text { Depth } \\
\text { Feet }\end{array}$ & $\begin{array}{l}\text { Ash } \\
\text { isopach } \\
\text { Feet }\end{array}$ & $\begin{array}{l}\text { Elevation } \\
\text { of basal } \\
\text { contact } \\
\text { Feet }\end{array}$ & $\begin{array}{l}\text { Elevatio } \\
\text { of basal } \\
\text { contact } \\
\text { Meters }\end{array}$ \\
\hline Fertilizerplant & 401 & 514451 & 5084311 & -12.3 & 55 & NG & $-62.3 \star$ & -19.0 \\
\hline $\begin{array}{l}\text { Boise Cascade } \\
\text { St Helens or }\end{array}$ & $\begin{array}{l}402 \\
404\end{array}$ & $\begin{array}{l}515389 \\
515362\end{array}$ & $\begin{array}{l}5076933 \\
5076858\end{array}$ & $\begin{array}{r}23 \\
23.5\end{array}$ & $\begin{array}{r}104.7 \\
94.4\end{array}$ & $\begin{array}{l}1.0 \\
0.5\end{array}$ & $\begin{array}{r}-57 \\
-53.5\end{array}$ & $\begin{array}{l}-17.4 \\
-16.3\end{array}$ \\
\hline Lewis Riv. Site & 407 & 518046 & 5077334 & 10 & 94.4 & 5.5 & -54.1 & -16.5 \\
\hline T3NR1W26 & 418 & 517615 & 5061995 & 12 & 169 & 7.0 & -61 & -18.6 \\
\hline N Marine Dr & $\begin{array}{l}564 \\
566 \\
567\end{array}$ & $\begin{array}{l}521969 \\
522161 \\
522277\end{array}$ & $\begin{array}{l}5051372 \\
5051381 \\
5051390\end{array}$ & $\begin{array}{l}33.17 \\
32.18 \\
25.87\end{array}$ & $\begin{array}{r}100.8 \\
119 \\
113.3\end{array}$ & $\begin{array}{l}5.5 \\
3.0 \\
6.5\end{array}$ & $\begin{array}{r}-48.33 \\
-46 \\
-51.1\end{array}$ & $\begin{array}{l}-14.7 \\
-14.0 \\
-15.6\end{array}$ \\
\hline $\begin{array}{l}\text { ODOT } \\
\text { I- } 205 \\
\text { Airport } \\
\text { Interchange }\end{array}$ & $\begin{array}{l}645 \\
646 \\
648 \\
649\end{array}$ & $\begin{array}{l}535338 \\
535262 \\
535254 \\
535300\end{array}$ & $\begin{array}{l}5046248 \\
5046190 \\
5046304 \\
5046317\end{array}$ & $\begin{array}{r}41.2 \\
16 \\
16.6 \\
18.6\end{array}$ & $\begin{array}{r}139 \\
199.5 \\
205 \\
253.5\end{array}$ & $\begin{array}{c}<2 \\
\text { streaks } \\
<2 \\
<1.5\end{array}$ & $\begin{array}{r}-47.8 \\
-50 \\
-52.9 \\
-50.8\end{array}$ & $\begin{array}{l}-14.6 \\
-15.2 \\
-16.1 \\
-15.5\end{array}$ \\
\hline $\begin{array}{l}\text { PGE } \\
\text { Sundial Rd }\end{array}$ & 748 & 544677 & 5044930 & 21 & 89.5 & 2.5 & -45.5 & -13.9 \\
\hline $\begin{array}{l}\text { Vanport } \\
\text { Site }\end{array}$ & $\begin{array}{l}769 \\
772 \\
774 \\
775 \\
776\end{array}$ & $\begin{array}{l}523447 \\
522799 \\
523711 \\
523823 \\
524463\end{array}$ & $\begin{array}{l}5050282 \\
5049647 \\
5049213 \\
5049566 \\
5048845\end{array}$ & $\begin{array}{l}11 \\
14.2 \\
11.6 \\
15.8 \\
14.3\end{array}$ & $\begin{array}{r}91 \\
91.2 \\
102.6 \\
97.3 \\
121.3\end{array}$ & $\begin{array}{l}2.5 \\
6.0 \\
9.0 \\
2.5 \\
0.5\end{array}$ & $\begin{array}{l}-51.5 \\
-55.5 \\
-56 \\
-49.5 \\
-56.5\end{array}$ & $\begin{array}{l}-15.7 \\
-16.9 \\
-17.1 \\
-15.1 \\
-17.2\end{array}$ \\
\hline $\begin{array}{l}\text { Crown } z \text {. } \\
\text { N Marine } D x\end{array}$ & $\begin{array}{l}778 \\
779 \\
780 \\
781\end{array}$ & $\begin{array}{l}523540 \\
523369 \\
523303 \\
523212\end{array}$ & $\begin{array}{l}5050703 \\
5050506 \\
5050531 \\
5050572\end{array}$ & $\begin{array}{r}26 \\
11 \\
10 \\
8\end{array}$ & $\begin{array}{r}117 \\
97 \\
93 \\
91\end{array}$ & $\begin{array}{l}3.5 \\
1.5 \\
2.5 \\
3.0\end{array}$ & $\begin{array}{r}-52.5 \\
-52 \\
-54 \\
-54.5\end{array}$ & $\begin{array}{l}-16.0 \\
-15.8 \\
-16.5 \\
-16.6\end{array}$ \\
\hline $\begin{array}{l}\text { Delta Park } \\
\text { West }\end{array}$ & $\begin{array}{l}786 \\
787 \\
789\end{array}$ & $\begin{array}{l}524351 \\
524152 \\
524256\end{array}$ & $\begin{array}{l}5050102 \\
5050020 \\
5050012\end{array}$ & $\begin{array}{l}18.7 \\
22.9 \\
16.2\end{array}$ & $\begin{array}{l}120.2 \\
117.9 \\
116.2\end{array}$ & $\begin{array}{l}2.5 \\
5.5 \\
4.0\end{array}$ & $\begin{array}{r}-50.5 \\
-56.5 \\
-54\end{array}$ & $\begin{array}{l}-15.4 \\
-17.2 \\
-16.5\end{array}$ \\
\hline $\begin{array}{l}\text { Delta Park } \\
\text { East }\end{array}$ & 793 & 526400 & 5048698 & 8 & 78 & 3.5 & -51 & -15.5 \\
\hline $\begin{array}{l}\text { POP } \\
\text { Rivergate }\end{array}$ & $\begin{array}{l}800 \\
801\end{array}$ & $\begin{array}{l}522062 \\
521821\end{array}$ & $\begin{array}{l}5051487 \\
5050255\end{array}$ & $\begin{array}{r}20 \\
7\end{array}$ & $\begin{array}{r}120 \\
75\end{array}$ & $\begin{array}{l}1.0 \\
6.0\end{array}$ & $\begin{array}{l}-44 \\
-52\end{array}$ & $\begin{array}{l}-13.4 \\
-15.8\end{array}$ \\
\hline
\end{tabular}




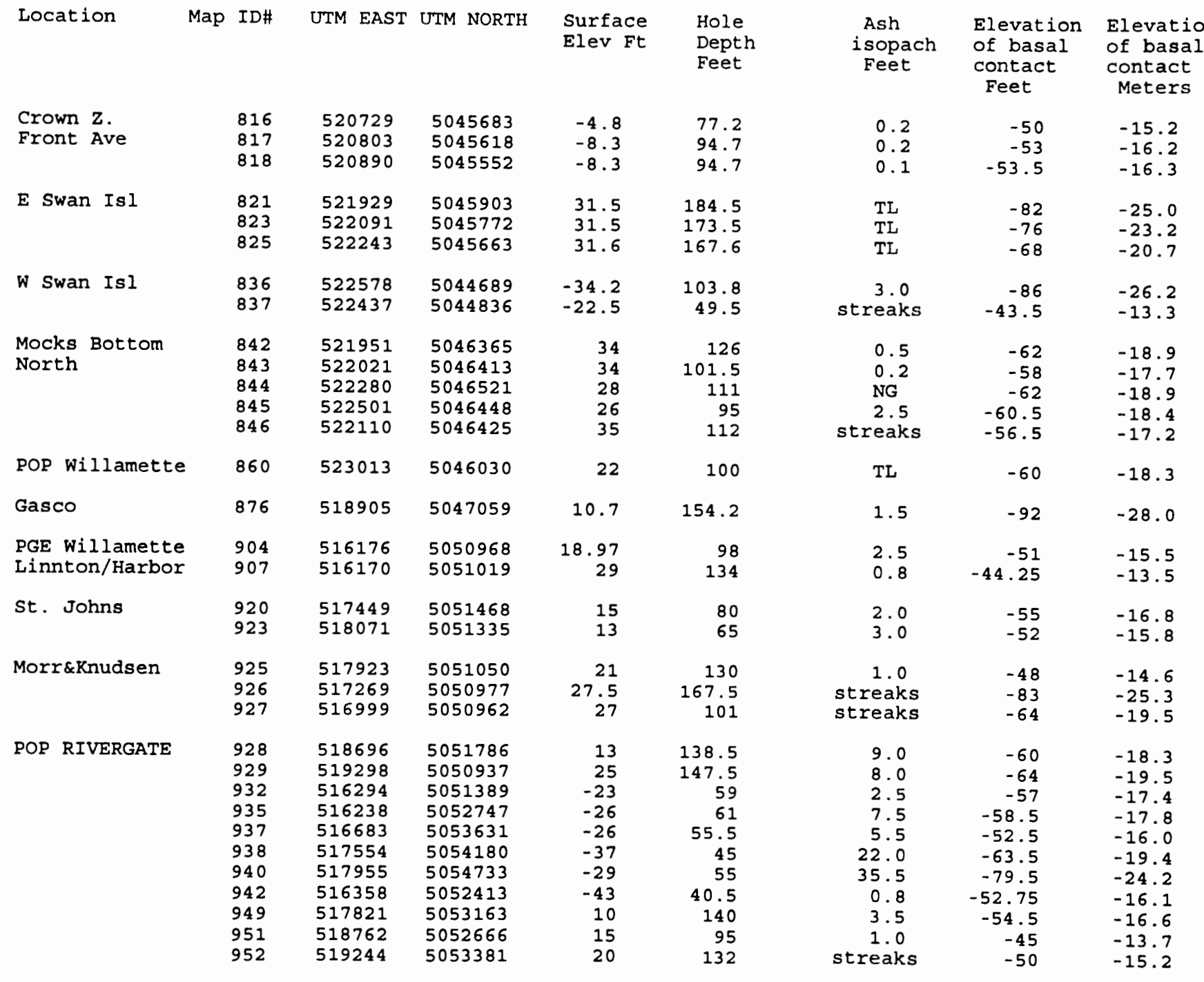


Hole Elev Ft

Ash
isopach
Feet
of basal contact Feet

Elevation Feet

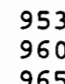

518175

517912

518789

5053789

5053468

5053463

30
34
12.2

160

160

99.5

Grain Terminal

974

518046

5054123

Oregon

steel Mills

982

516759

517097

5052567

5052434

30

120

101.1

2.0

5.5
NG

NG

NG
1.0

79.5
-54

-54
-83.8

$-60$

-69
-66
3.15

$-56.77$

Upper basin averages

$\begin{array}{llll}\text { JDR Cow Pasture } & 1033 & 442812 & 5112569 \\ \text { John Day River } & 1034 & 442084 & 5112587 \\ \text { Bridge } & 1035 & 442136 & 5112590 \\ & 1036 & 442138 & 5112561 \\ \text { ODOT TngPt-Br } & 1037 & 442667 & 5114141 \\ \text { Marys Crk } & 1050 & 448158 & 5112871 \\ \text { Bridge } & 1051 & 448214 & 5112852 \\ \text { Gnat Crk Bdg } & 1059 & 458825 & 5114911 \\ \text { Blind Slough } & 1061 & 458236 & 5116428 \\ \text { Bridge } & 1062 & 458235 & 5116467 \\ & 1063 & 458237 & 5116502 \\ & 1096 & 446023 & 5131340 \\ \text { WASHDoT } & 1097 & 446062 & 5131321 \\ \text { Deep River } & 1101 & 446202 & 5131283 \\ \text { Bridge } & 1102 & 446211 & 5131267 \\ & & & \\ \text { Ranglia Slough } & 1108 & 446642 & 5130958 \\ & 1111 & 446650 & 5130896 \\ \text { Skippanon Bridge } & 1163 & 429023 & 5112601 \\ \text { Warrenton Or } & 1164 & 428939 & 5112593 \\ \text { Holbrook Slough } & 1165 & 430600 & 5112084\end{array}$

$\begin{array}{rr}9.5 & 80.5 \\ 7.3 & 132.5 \\ 9.1 & 127 \\ 19.8 & 98 \\ -1 & 131 \\ 5 & 80 \\ 5 & 98 \\ & \\ 10 & 120 \\ 18 & 114.5 \\ 20.2 & 131.5 \\ 20.5 & 160 \\ & \\ 4 & 129 \\ 5 & 189 \\ 8.8 & 240.33 \\ 4 & 245 \\ & \\ 4 & 245 \\ 8.8 & 91.5 \\ 10.5 & 102 \\ 9.8 & 99.5 \\ 5 & 120.5\end{array}$

4.0

6.0

3.0

4.5

1.0

NG

NG

6.6

$<1.5$
0.5
0.5

1. 5

2. 5

5.0

1.5

3.0

2.5

1.5
1.0

1.0
$-48.5$

$-58.7$

$-52.9$

$-56.2$

$$
-70
$$$$
-41
$$$$
-80
$$

$-62.6$

$-82.5$

-71.3
-53

$-57.5$

-61
-61.2

$-59.5$

-64
-63.7

$-66.5$

$-62.7$

$-60.5$ of basal

contact

Meters

$-24.2$

$-16.5$

$-25.5$

$-18.3$

-21.0
-20.1

$-17.3$

$-14.8$

$-17.9$

$-16.1$

$-17.1$

$-21.3$

$-12.5$

$-24.4$

$-19.1$

$-25.1$

$-21.7$

$-16.2$

$-17.5$

$-18.6$

$-18.7$

$-18.1$

$-19.5$

$-19.4$

$-20.3$

$-19.1$

$-18.4$ 


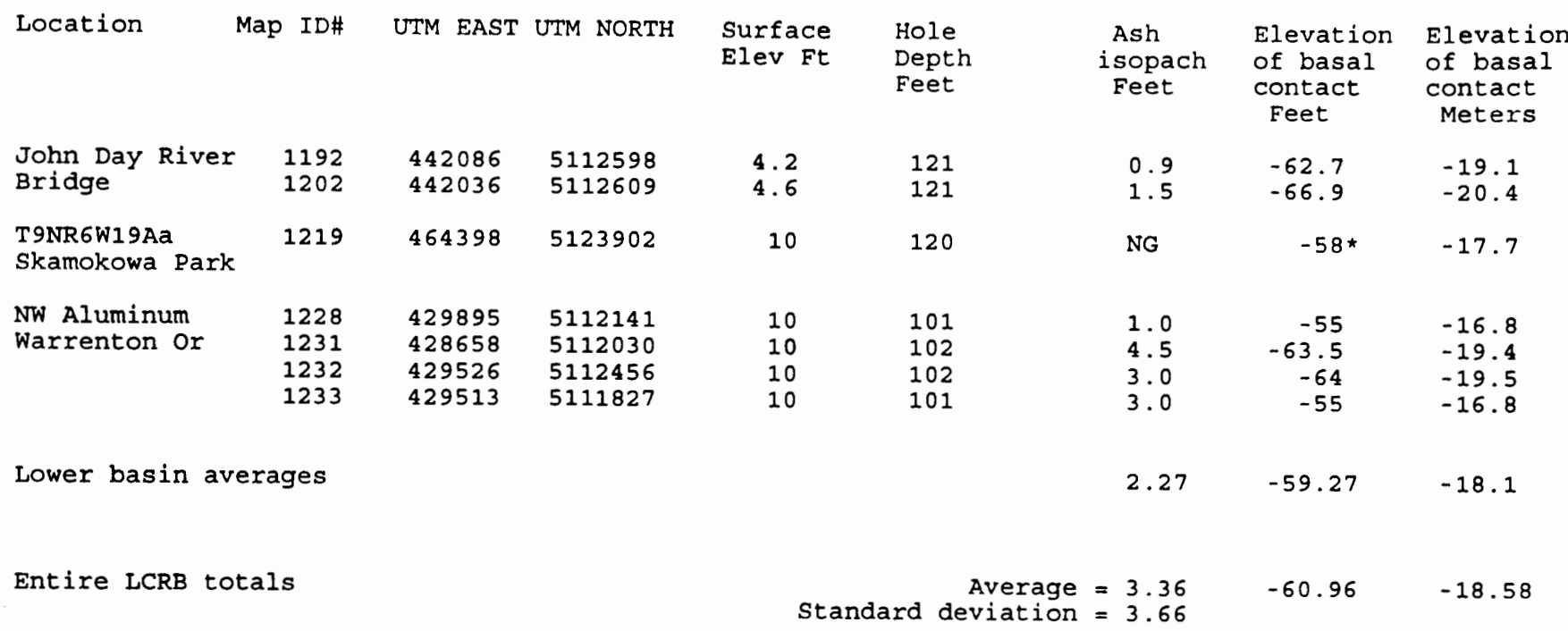

NG $=$ Not Given (usually indicates ash or pumice noted on log but no thickness given) $T L=$ Thin Layer

* Top Contact Elevation

All isopachs indicated as NG. TL, or streaks were assigned a thickness of 0.1 feet for the calculations.

All values listed as less than (<) assumed the maximum isopach indicated for the calculations. 
APPENDIX D

SEDIMENT GRAIN SIZE DISTRIBUTION DATA 
SEDIMENT GRAIN SIZE DISTRIBUTION DATA

\begin{tabular}{|c|c|c|c|c|c|c|c|c|c|}
\hline HOLE\# & ISOPACH & $\begin{array}{l}\text { SAND } \\
\text { FEET }\end{array}$ & $\begin{array}{c}\text { SILTYSAND } \\
\text { FEET }\end{array}$ & $\begin{array}{c}\text { SANDYSILT } \\
\text { FEET }\end{array}$ & $\begin{array}{l}\text { SILT } \\
\text { FEET }\end{array}$ & 气 SAND & \%SILTYSND & ¿SANDYSLT & 웋SILI \\
\hline 1203 & 288 & 282 & 0 & 0 & 6 & 97.9 & 0.0 & 0.0 & 2.1 \\
\hline 1226 & 111 & 103.5 & 2.5 & 4 & 1 & 93.2 & 2.3 & 3.6 & 0.9 \\
\hline 1161 & 142.5 & 126 & 12.5 & 0 & 4 & 88.4 & 8.8 & 0.0 & 2.8 \\
\hline 1171 & 151.5 & 20 & 131.5 & 0 & 0 & 13.2 & 86.8 & 0 & 0 \\
\hline 1170 & 150 & 4 & 49 & 77 & 20 & 2.7 & 32.7 & 51.3 & 13.3 \\
\hline 1186 & 191 & 35.5 & 0 & 120 & 35.5 & 18.6 & 0.0 & 62.8 & 18.6 \\
\hline 1179 & 122.5 & 111.25 & 0 & 0 & 11.25 & 90.8 & 0.0 & 0.0 & 9.2 \\
\hline 1181 & 107.5 & 73.75 & 0 & 0 & 33.75 & 68.6 & 0.0 & 0.0 & 31.4 \\
\hline 1109 & 213 & 0 & 69 & 142 & 2 & 0.0 & 32.4 & 66.7 & 0.9 \\
\hline 1104 & 227 & 0 & 107 & 120 & 0 & 0.0 & 47.1 & 52.9 & 0.0 \\
\hline 1060 & 143.3 & 7 & 7.15 & 7.15 & 122 & 4.9 & 5.0 & 5.0 & 85.1 \\
\hline 1089 & 267 & 0 & 245 & 22 & 0 & 0.0 & 91.8 & 8.2 & 0.0 \\
\hline 1085 & 216.5 & 0 & 197 & 19.5 & 0 & 0.0 & 91.0 & 9.0 & 0.0 \\
\hline 1070 & 61 & 52 & 0 & 9 & 0 & 85.2 & 0.0 & 14.8 & 0.0 \\
\hline 1292 & 250 & 35 & 145 & 25 & 45 & 14.0 & 58.0 & 10.0 & 18.0 \\
\hline 1120 & 151 & 98 & 31 & 13 & 9 & 64.9 & 20.5 & 8.6 & 6.0 \\
\hline 1154 & 295 & 236 & 4 & 0 & 55 & 80.0 & 1.4 & 0.0 & 18.6 \\
\hline 1157 & 119.5 & 70 & 49.5 & 0 & 0 & 58.6 & 41.4 & 0.0 & 0.0 \\
\hline 1071 & 150 & 90 & 20 & 10 & 30 & 60 & 13.3 & 6.7 & 20 \\
\hline 1073 & 138 & 127 & 4.5 & 4.5 & 2 & 92 & 3.3 & 3.3 & 1.4 \\
\hline 246 & 99.5 & 80 & 0 & 7 & 12.5 & 80.4 & 0.0 & 7.0 & 12.6 \\
\hline 247 & 148.5 & 139 & 0 & 4 & 5.5 & 93.6 & 0.0 & 2.7 & 3.7 \\
\hline 248 & 152 & 111 & 11 & 15.5 & 14.5 & 73.0 & 7.2 & 10.2 & 9.6 \\
\hline 249 & 137 & 109 & 0 & 22.5 & 5.5 & 79.6 & 0.0 & 16.4 & 4.0 \\
\hline 260 & 320 & 255 & 0 & 0 & 65 & 79.7 & 0.0 & 0.0 & 20.3 \\
\hline 258 & 308 & 161 & 61 & 78 & 8 & 52.3 & 19.8 & 25.3 & 2.6 \\
\hline 137 & 223 & 45 & 7 & 159 & 12 & 20.2 & 3.1 & 71.3 & 5.4 \\
\hline 102 & 225 & 20 & 14 & 34 & 157 & 8.9 & 6.2 & 15.1 & 69.8 \\
\hline 15 & 209 & 50 & 15 & 50 & 94 & 23.9 & 7.2 & 23.9 & 45.0 \\
\hline 31 & 181 & 122 & 21.5 & 0 & 37.5 & 67.4 & 11.9 & 0.0 & 20.7 \\
\hline 197 & 178 & 49 & 78.5 & 0 & 50.5 & 27.5 & 44.1 & 0.0 & 28.4 \\
\hline 193 & 149 & 96.5 & 7.5 & 28.5 & 16.5 & 64.8 & 5 & 19.1 & 11.1 \\
\hline 194 & 153.5 & 95.5 & 7.5 & 50.5 & 0 & 62.2 & 4.9 & 32.9 & 0.0 \\
\hline 1269 & 269 & 154 & 0 & 0 & 115 & 57.2 & 0 & 0 & 42.8 \\
\hline 216 & 290 & 143 & 37 & 55 & 55 & 49.3 & 12.8 & 19.0 & 19.0 \\
\hline 262 & 325 & 96 & 117 & 112 & 0 & 29.5 & 36.0 & 34.5 & 0.0 \\
\hline 353 & 106.2 & 84.7 & 21.5 & 0 & 0 & 79.8 & 20.2 & 0.0 & 0.0 \\
\hline 401 & 55 & 55 & 0 & 0 & 0 & 100.0 & 0.0 & 0.0 & 0.0 \\
\hline 1302 & 190 & 149 & 0 & 0 & 41 & 78.4 & 0.0 & 0.0 & 21.6 \\
\hline 1314 & 194 & 130 & 5 & 0 & 59 & 67.0 & 2.6 & 0.0 & 30.4 \\
\hline 977 & 144.5 & 127.5 & 16 & 1 & 0 & 88.2 & 11.1 & 0.7 & 0.0 \\
\hline 970 & 170.5 & 82.5 & 26.5 & 59.5 & 2 & 48.4 & 15.5 & 34.9 & 1.2 \\
\hline
\end{tabular}




\begin{tabular}{|c|c|c|c|c|c|c|c|c|c|}
\hline HOLE\# & ISOPACH & $\begin{array}{l}\text { SAND } \\
\text { FEET }\end{array}$ & $\begin{array}{c}\text { SILTYSAND } \\
\text { FEET }\end{array}$ & $\begin{array}{c}\text { SANDYSILT } \\
\text { FEET }\end{array}$ & $\begin{array}{l}\text { SILT } \\
\text { FEET }\end{array}$ & \% SAND & \&SILTYSND & ¿SANDYSLT & 음SILT \\
\hline 632 & 103.5 & 103.5 & 0 & 0 & 0 & 100.0 & 0.0 & 0.0 & 0.0 \\
\hline 637 & 175 & 175 & 0 & 0 & 0 & 100.0 & 0.0 & 0.0 & 0.0 \\
\hline 926 & 149 & 125 & 0 & 9.5 & 14.5 & 83.9 & 0.0 & 6.4 & 9.7 \\
\hline 831 & 150.5 & 96.5 & 54 & 0 & 0 & 64.1 & 35.9 & 0.0 & 0.0 \\
\hline 834 & 142 & 80 & 23 & 39 & 0 & 56.3 & 16.2 & 27.5 & 0.0 \\
\hline 899 & 177 & 145.5 & 19 & 0 & 12.5 & 82.2 & 10.7 & 7.1 & 0.0 \\
\hline 512 & 98.5 & 94.5 & 4 & 0 & 0 & 95.9 & 4.1 & 0.0 & 0.0 \\
\hline 528 & 130 & 130 & 0 & 0 & 0 & 100.0 & 0.0 & 0.0 & 0.0 \\
\hline 533 & 210 & 167 & 9 & 34 & 0 & 79.5 & 4.3 & 16.2 & 0.0 \\
\hline 535 & 234 & 173 & 18 & 43 & 0 & 73.9 & 7.7 & 18.4 & 0.0 \\
\hline 747 & 75.5 & 51 & 2 & 2 & 20.5 & 67.6 & 2.6 & 2.6 & 27.2 \\
\hline 748 & 87.5 & 5.5 & 6 & 26 & 50 & 6.3 & 6.9 & 29.7 & 57.1 \\
\hline Borehole & Percent & & & & & 58.8 & 15.4 & 13.4 & 12.4 \\
\hline Isopach & Percent & & & & & 54.70 & 17.51 & 14.84 & 12.95 \\
\hline
\end{tabular}


APPENDIX D SEDIMENT GRAIN SIZE DISTRIBUTION FOR SUBSURFACE ELEVATION INTERVALS

HOLE\#

0-33 METER INTERVAL

\section{\&SAND $\%$ SILTYSND $\&$ SANDYSLT $\%$ SILT}

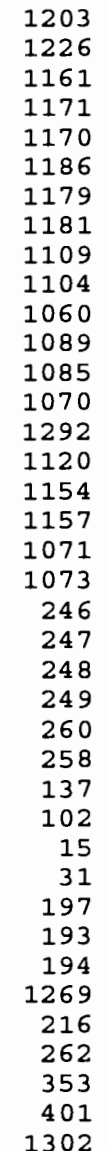

33-66 METER INTERVAL

\section{\&SAND $\%$ SILTYSND \&SANDYSLT}

100.0
84.8
87.9
0
0
50.0
60.6
50.0
0.0
0.0
0.0
0.0
0.0
100.0

0.0
0.0
0.0
100
33.3
0.0
0.0
0.0
0.0
39.4
0.0
100.0
93.9
0.0

0.0
15.2
0.0
0
33.4
0.0
0.0
0.0
100.0
60.6
0.0
0.0
6.1
0.0

97.0
100.0

100.0
100.0

39.4

100

100.0

100.0

100.0
100.0

100.0

9.1

0.0

0.0

100.0

0.0
19.7

13.6

0.0

18.2

82.4

100.0

100.0
3.0
0.0
0.0
60.6
0
0.0
0.0
0.0
0.0
0.0
90.9
0.0
18.1
0.0
0.0
100.0
22.7
10.6
0
0.0
81.8
17.6
0.0
0.0
0.0

0.0
0.0
12.1

12. 1

33.3

50.0

39.4

0.0

0.0

100.0

0.0

0.0
0.0

0.0
0.0

0.0
0.0

0
0

0.0

0.0

0.0

0.0

0.0

0.0

17.0

17.0

33.3

0.0
0.0

7.6

75.8

5
0

0.0
0.0

0.0

0.0
0.0

0.0
0.0

0.0
0.0

0.0

0
0

0.0

0.0

0.0

0.0

0.0

0.0
9.1

64.9

66.7

0.0

0.0
50

0.0

100

100.0

0.0

0.0

0.0
66-99 METER INTERVAL

\section{\&SAND कSILTYSND $\%$ SANDYSLT $\%$ SILT}

$\begin{array}{rrrr}100.0 & 0.0 & 0.0 & 0.0 \\ 86.3 & 7.6 & 6.1 & 0.0 \\ 100.0 & 0.0 & 0.0 & 0.0 \\ 0 & 100 & 0 & 0 \\ 12.1 & 84.8 & 3.1 & 0 \\ 50.0 & 0.0 & 0.0 & 50.0 \\ 100.0 & 0.0 & 0.0 & 0.0 \\ 81.8 & 0.0 & 0.0 & 18.2 \\ 0.0 & 27.3 & 72.7 & 0.0 \\ 0.0 & 100.0 & 0.0 & 0.0 \\ 0.0 & 0.0 & 0.0 & 100.0 \\ 0.0 & 100.0 & 0.0 & 0.0 \\ 0.0 & 100.0 & 0.0 & 0.0 \\ & & & \\ 12.1 & 87.9 & 0.0 & 0.0 \\ 66.6 & 16.7 & 16.7 & 0.0 \\ 100.0 & 0.0 & 0.0 & 0.0 \\ 71.8 & 28.2 & 0.0 & 0.0 \\ 100 & 0 & 0 & 0 \\ 100 & 0 & 0 & 0 \\ 100.0 & 0.0 & 0.0 & 0.0 \\ 100.0 & 0.0 & 0.0 & 0.0 \\ 100.0 & 0.0 & 0.0 & 0.0 \\ 100.0 & 0.0 & 0.0 & 0.0 \\ 100.0 & 0.0 & 0.0 & 0.0 \\ 84.8 & 0.0 & 15.2 & 0.0 \\ 0.0 & 0.0 & 100.0 & 0.0 \\ 0.0 & 0.0 & 0.0 & 100.0 \\ 0.0 & 0.0 & 0.0 & 100.0 \\ 22.7 & 40.9 & 0.0 & 36.3 \\ 33.3 & 66.7 & 0.0 & 0.0 \\ 21.2 & 0 & 78.8 & 0 \\ 22.7 & 0.0 & 77.3 & 0.0 \\ 0 & 0 & 0 & 100 \\ 0.0 & 0.0 & 93.9 & 6.1 \\ 48.5 & 0.0 & 51.5 & 0.0 \\ 66.7 & 33.3 & 0.0 & 0.0 \\ & & & \\ 100.0 & 0.0 & 0.0 & 0.0 \\ & & & \end{array}$


HOLE\#

0-33 METER INTERVAL

\%SAND \%SILTYSND \%SANDYSLT \%SILT

1314
977
970
632
637
926
831
834
899
512
528
533
535
747
748

TOTALS
31.8

0.0

100.0

54.5

87.9

87.9

60.6

100.0

100.0

42.4

9.1

36.3

16.7

49.2
0.0

0.0

0.0

0.0

12. 1

39.4

0.0

0.0
27.3

27.3

39.4

31.8

17.5
0.0

100.0

0.0
28.8

28.8

0.0
0.0

0.0

0.0

0.0

30.3

51.5

6.1

16.4
33-66 METER INTERVAL

₹SAND \&SILTYSND \%

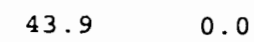

$63.6 \quad 33.3$

$0.0 \quad 80.3$

$100.0 \quad 0.0$

$100.0 \quad 0.0$

$100.0 \quad 0.0$

$\begin{array}{ll}100.0 & 0.0 \\ 100.0 & 0.0\end{array}$

$81.8 \quad 18.2$

$100.0 \quad 0.0$

$100.0 \quad 0.0$

100.0

100.0

100.0

0.0

0.0
0.0

0.0

10.6

58.5

17.3
$0.0 \quad 56.1$

0.0

$18.2 \quad 1.5$

0.0

0.0

0.0

0.0

0.0

0.0

0.0

0.0

0.0

0.0

0.0
25.8

9.2
66-99 METER INTERVAI

\%SAND \%SILTYSND $\%$ SANDYSLT $\%$ SILT

$\begin{array}{rrrr}68.2 & 0.0 & 0.0 & 31.8 \\ 100.0 & 0.0 & 0.0 & 0.0 \\ 65.2 & 0.0 & 34.8 & 0.0 \\ 100.0 & 0.0 & 0.0 & 0.0 \\ 100.0 & 0.0 & 0.0 & 0.0 \\ 100.0 & 0.0 & 0.0 & 0.0 \\ 54.5 & 45.5 & 0.0 & 0.0 \\ 44.0 & 0.0 & 56.0 & 0.0 \\ 86.4 & 0.0 & 0.0 & 13.6 \\ 87.9 & 12.1 & 0.0 & 0.0 \\ 100.0 & 0.0 & 0.0 & 0.0 \\ 100.0 & 0.0 & 0.0 & 0.0 \\ 84.8 & 15.2 & 0.0 & 0.0 \\ & & & \end{array}$


APPENDIX D

SEDIMENT GRAIN SIZE DISTRIBUTION FOR SUBSURFACE ELEVATION INTERVALS (continued)

HOLE\# 99-131 METER INTERVAL \&SAND \&SILTYSND \&SANDYSLT \&SILT

1203
1226
1161
1171
1170
1186
1179
1181
1109
1104
1060
1089
1085
1070
1292
1120
1154
1157
1071
1073
246
247
248
249
260
258
137
102
15
31
197
193
194
1269
216
262
353
401
1302

$\begin{array}{rr}100.0 & 0.0 \\ 62.1 & 37.9 \\ 0 & 100 \\ 0 & 0 \\ 29.7 & 0.0 \\ 100.0 & 0.0 \\ 100.0 & 0.0 \\ 0.0 & 59.4 \\ 0.0 & 18.8 \\ 21.9 & 30.0 \\ 0.0 & 100.0 \\ 0.0 & 100.0 \\ & \\ 0.0 & 31.3 \\ 9.4 & 46.8 \\ 100.0 & 0.0 \\ 0.0 & 100.0 \\ 100 & 0 \\ 100 & 0 \\ & \\ 100.0 & 0.0 \\ 100.0 & 0.0 \\ 100.0 & 0.0 \\ 36.4 & 0.0 \\ 0.0 & 0.0 \\ 0.0 & 0.0 \\ 0.0 & 0.0 \\ 0.0 & 15.1 \\ 68.7 & 0.0 \\ 0.0 & 20.3 \\ 100 & 0 \\ 100.0 & 0.0 \\ 87.5 & 0 \\ 0.0 & 93.9 \\ 0.0 & 90.6 \\ & \\ 00 & \\ 0.0 & \\ 0.0 & \\ 0.0 & \\ 0.0 & \\ 0.0 & \end{array}$

\begin{abstract}
0.0
\end{abstract}
0.0

0.0

100

40.6

0.0

0.0

34.4

81.2

30.0

0.0
0.0

68.7

68.7
43.8

43.8
0.0

0.0

0
0

0.0

0.0
0.0

0.0

100.0

100.0

0.0

0.0

0.0

0

0.0

0
6.1

9.4

100.0

79.7

0.0
12.5

0.0
0.0
131-164 METER INTERVAL

\&SAND \&SILTYSND \&SANDYSLT \&SILT

$\begin{array}{rrrr}100.0 & 0.0 & 0.0 & 0.0 \\ 0 & 100 & 0 & 0 \\ 0 & 0 & 100 & 0 \\ 0.0 & 0.0 & 100.0 & 0.0 \\ 100.0 & 0.0 & 0.0 & 0.0 \\ 0.0 & 0.0 & 100.0 & 0.0 \\ 0.0 & 0.0 & 100.0 & 0.0 \\ 0.0 & 100.0 & 0.0 & 0.0 \\ 0.0 & 100.0 & 0.0 & 0.0 \\ 0.0 & 0.0 & 12.1 & 87.9 \\ 100.0 & 0.0 & 0.0 & 0.0 \\ 100.0 & 0.0 & 0.0 & 0.0\end{array}$

42.4
0.0
0.0
54.5
78.8
100.0
0.0
100
100.0
100
78.8
90.9

0.0
0.0
0.0
7.6
21.2
0.0
30.3
0
0.0
0
21.2
9.1

0.0
100.0
100.0
0.0
0.0
0.0
0.0
0
0.0
0
0.0
0.0
57.6
0.0
0.0
0.0
0.0
69.7
0.0
0.0

0.0

0.0

100.0

0.0

0.0
63.6
75.8
39.4
0.0
54.5


100
100.0
78.8

$\begin{array}{rrr}0.0 & 0.0 & 36.4 \\ 0.0 & 24.2 & 0.0 \\ 21.2 & 30.3 & 9.1 \\ 9.1 & 0.0 & 90.9 \\ 9.1 & 36.4 & 0.0\end{array}$

0.0

0.0

$\begin{array}{rrr}0 & 0 & 0 \\ 0.0 & 0.0 & 0.0 \\ 0.0 & 21.2 & 0.0\end{array}$

164-197 METER INTERVAL

\&SAND \&SILTYSND \&SANDYSIT \&SILT

$\begin{array}{llll}100.0 & 0.0 & 0.0 & 0.0\end{array}$

$\begin{array}{llll}0.0 & 0.0 & 100.0 & 0.0\end{array}$

$\begin{array}{llll}0.0 & 51.5 & 48.5 & 0.0 \\ 0.0 & 6.1 & 93.9 & 0.0\end{array}$

$\begin{array}{llll}0.0 & 100.0 & 0.0 & 0.0\end{array}$

$\begin{array}{llll}0.0 & 100.0 & 0.0 & 0.0\end{array}$

$\begin{array}{llll}0.0 & 51.5 & 0.0 & 48.5\end{array}$

$\begin{array}{llll}18.2 & 0.0 & 0.0 & 81.8\end{array}$ 
HOLE\#

99-131 METER INTERVAL \%SAND

131

977

970

632

637
926

831

831
834

899

512

528

533
535

747

748

TOTALS

53.4

22.2

14.5

10.0

56.5

13.4

8.9

$46.1-19.4$

$19.7 \quad 14.8$
164-197 METER INTERVAL

\&SAND \&SILTYSND $\%$ SANDYSLT $\%$ SILT

$\begin{array}{rrr}15.6 & 0.0 & 0.0 \\ 0.0 & 0.0 & 0.0\end{array}$

87.9

7.6

4.

0.0

0.0

0.0

0.0

0.0

100.0

0.0

0.0

0.0
0.0

100.0

100.0

0.0

0.

0.0

0.0

0 
APPENDIX D SEDIMENT GRAIN SIZE DISTRIBUTION FOR SUBSURFACE ELEVATION INTERVALS

\section{(continued)}

HOLE\# 197-230 METER INTERVAL

230-262 METER INTERVAL

1203

1226

1161

1171

1186

1179

1109

1104

1060

1089

1085

1070
1292
1120

1292
1120
1154
1157

1071

1073

246
247

247

249

260

258

$100.0 \quad 0.0$

$\begin{array}{lll}100.0 & 0.0 & 0.0 \\ 100.0 & 0.0 & 0.0\end{array}$

$40.9 \quad 7.6$

51.5

$\begin{array}{rrr}100 & 0 & 0 \\ 100.0 & 0.0 & 0.0 \\ 0.0 & 0.0 & 100.0\end{array}$

$$
0
$$

100
100.0
0.0

0
0.0
0.0

0
0.0
100.0

$\begin{array}{rrr}0 & & \\ 0.0 & 100.0 & 0.0 \\ 0.0 & 0.0 & 100.0\end{array}$

